\title{
38. MIDDLE EOCENE TO PLEISTOCENE DIATOM BIOSTRATIGRAPHY OF SOUTHERN OCEAN SEDIMENTS FROM THE KERGUELEN PLATEAU, LEG $120^{1}$
}

\author{
David M. Harwood ${ }^{2}$ and Toshiaki Maruyama ${ }^{3}$
}

\begin{abstract}
The biostratigraphic distribution and abundance of lower Oligocene to Pleistocene diatoms is documented from Holes 747A, 747B, 748B, 749B, and 751A drilled during Ocean Drilling Program Leg 120 on the Kerguelen Plateau in the southeast Indian Ocean. The occurrence of middle and upper Eocene diatoms is also documented, but these are rare and occur in discrete intervals. The recovery of several Oligocene to Pleistocene sections with minimal coring gaps, relatively good magnetostratigraphic signatures, and mixed assemblages of both calcareous and siliceous microfossils makes the above four Leg 120 sites important biostratigraphic reference sections for the Southern Ocean and Antarctic continent. A high-resolution diatom zonation divides the last 36 m.y. into 45 zones and subzones. This zonation is built upon an existing biostratigraphic framework developed over the past $20 \mathrm{yr}$ of Southern Ocean/Antarctic deep-sea coring and drilling.

After the recent advances from diatom biostratigraphic studies on sediments from Legs 113, 114, 119, and 120, a zonal framework for the Southern Ocean is beginning to stabilize. The potential age resolution afforded by the high-diversity diatom assemblages in this region ranks among the highest of all fossil groups. In addition to the 46 datum levels that define the diatom zones and subzones, the approximate stratigraphic level, age, and magnetic anomaly correlative of more than 150 other diatom datums are determined or estimated. These total 73 datum levels for the Pliocene-Pleistocene, 67 for the Miocene, and 45 for the Oligocene. Greater stratigraphic resolution is possible as the less common and poorly documented species become better known.

This high-resolution diatom stratigraphy, combined with good to moderately good magnetostratigraphic control, led to the recognition of more than 10 intervals where hiatuses dissect the Oligocene-Pleistocene section on the Kerguelen Plateau. We propose 12 new diatom taxa and 6 new combinations in this paper; an additional 41 unknown or poorly documented diatoms are treated with informal nomenclature.
\end{abstract}

\section{INTRODUCTION}

Ocean Drilling Program (ODP) Leg 120 drilled 12 holes at 5 sites on the Central Kerguelen Plateau during March and April of 1988 (Schlich, Wise, et al., 1989) (Table 1 and Fig. 1). All sites presently lie south of the Polar Front, within the Antarctic water mass. Leg 120 represents the second half of a two-leg latitudinal transect from the Northern Kerguelen Plateau to the Antarctic Margin near Prydz Bay. Leg 119 drilled numerous holes north and south of the Leg 120 sites (Barron, Larson, et al., 1989) (Fig. 1).

This report documents the biostratigraphic occurrence and abundance of marine diatoms from five holes on the Kerguelen Plateau. No individual hole spans the entire interval in which diatoms occur (middle Eocene to Pleistocene), but collectively, most ages are represented in at least two holes (Fig. 2). In general, Pliocene and Pleistocene sediments are of diatom ooze or foraminifer diatom ooze, with middle Eocene to upper Miocene sediments of nannofossil ooze or chalk. The exception to this is Site 751, in which the siliceous microfossils component is well represented throughout the Miocene nannofossil-rich interval. Near-continuous core recovery (Fig. 2) in several sites from the upper Oligocene to Pleistocene enables detailed biostratigraphic and paleoceanographic studies, although several hiatuses representing from 1 to $6 \mathrm{~m}$.y. are clearly present (see biostratigraphic synthesis

\footnotetext{
${ }^{1}$ Wise, S. W., Jr., Schlich, R., et al., 1992. Proc. ODP, Sci. Results, 120: College Station, TX (Ocean Drilling Program).

2 Department of Geology, 214 Bessey Hall, University of NebraskaLincoln, Lincoln, NE 68588-0340, U.S.A.

${ }^{3}$ Department of Earth Sciences, Yamagata University, Faculty of General Education, Yamagata 990, Japan.
}

chapter by Harwood et al., this volume). The lower range of consistent diatom recovery corresponds with the occurrence of chert in the lower Oligocene and Eocene.

This paper presents diatom biostratigraphic information in several forms. Stratigraphic distribution tables with relative abundance values are given in separate tables for the Pleistocene-Pliocene, the Miocene, and the Oligocene of each site. Magnetic polarity information, extrapolated ages, biostratigraphic zone division, and hiatus position are presented in accompanying figures. The extrapolated ages of diatom events from age-depth plots in Harwood et al. (this volume) are collected into a datum table for the Pleistocene-Pliocene, the Miocene, and the Oligocene. The Neogene biostratigraphy synthesis chapter (Harwood et al., this volume) should be consulted when evaluating and using this diatom paper. From these compilations of Leg 120 extrapolated ages and published ages, an average age is determined for each diatom event; younger ages for last occurrences (LOs) and older ages for first occurrences (FOs) are given priority in these determinations. Reference to published ages are largely from Weaver and Gombos (1981), Ciesielski (1983, 1986), Gersonde and Burckle (1990), and particularly Baldauf and Barron (1991). Because this paper represents the last of a series of diatom reports from recent ODP legs to the Southern Ocean, we attempted to bring together information obtained from the other legs into the present zonal scheme for intervals where hiatuses removed specific sections. This is particularly evident in the upper Miocene where we drew heavily on the stratigraphies produced by Ciesielski $(1983,1986)$, Gersonde and Burckle (1990), and Baldauf and Barron (1991). Much more data collection and analysis is still required on all of the materials collected during Legs 113,114, 119 and 120 and the potential age resolution based on diatoms alone has yet to be fully realized. 
Table 1. Statistics of ODP holes treated in this paper.

\begin{tabular}{|c|c|c|c|c|c|}
\hline Hole & Latitude & Longitude & $\begin{array}{l}\text { Water } \\
\text { depth } \\
\text { (m) }\end{array}$ & $\begin{array}{l}\text { Cores } \\
\text { studied }\end{array}$ & Ages \\
\hline $747 \mathrm{~A}$ & $54^{\circ} 48.68^{\prime}$ & $76^{\circ} 47.64^{\prime}$ & 1695.0 & $1 \mathrm{H}$ to $17 \mathrm{H}$ & $\begin{array}{l}\text { Pleistocene- } \\
\text { upper } \\
\text { Oligocene }\end{array}$ \\
\hline 747B & $54^{\circ} 48.68^{\prime}$ & $76^{\circ} 47.64^{\prime}$ & 1695.0 & $1 \mathrm{H}$ to $6 \mathrm{H}$ & $\begin{array}{l}\text { Pleistocene- } \\
\text { upper Miocene }\end{array}$ \\
\hline $748 B$ & $58^{\circ} 26.45^{\prime}$ & $78^{\circ} 58.89^{\prime}$ & 1290.9 & $1 \mathrm{H}$ to $20 \mathrm{H}$ & $\begin{array}{l}\text { Pleistocene- } \\
\text { middle Eocene }\end{array}$ \\
\hline $749 B$ & $58^{\circ} 43.03^{\prime}$ & $76^{\circ} 24.45^{\prime}$ & 1069.5 & $1 \mathrm{H}$ to $9 \mathrm{H}$ & $\begin{array}{l}\text { upper } \\
\text { Oligocene- } \\
\text { middle Eocene }\end{array}$ \\
\hline $751 \mathrm{~A}$ & $57^{\circ} 43.56^{\prime}$ & $79^{\circ} 48.89^{\prime}$ & 1633.8 & $1 \mathrm{H}$ to $18 \mathrm{H}$ & $\begin{array}{l}\text { Pleistocene- } \\
\text { lower Miocene }\end{array}$ \\
\hline
\end{tabular}

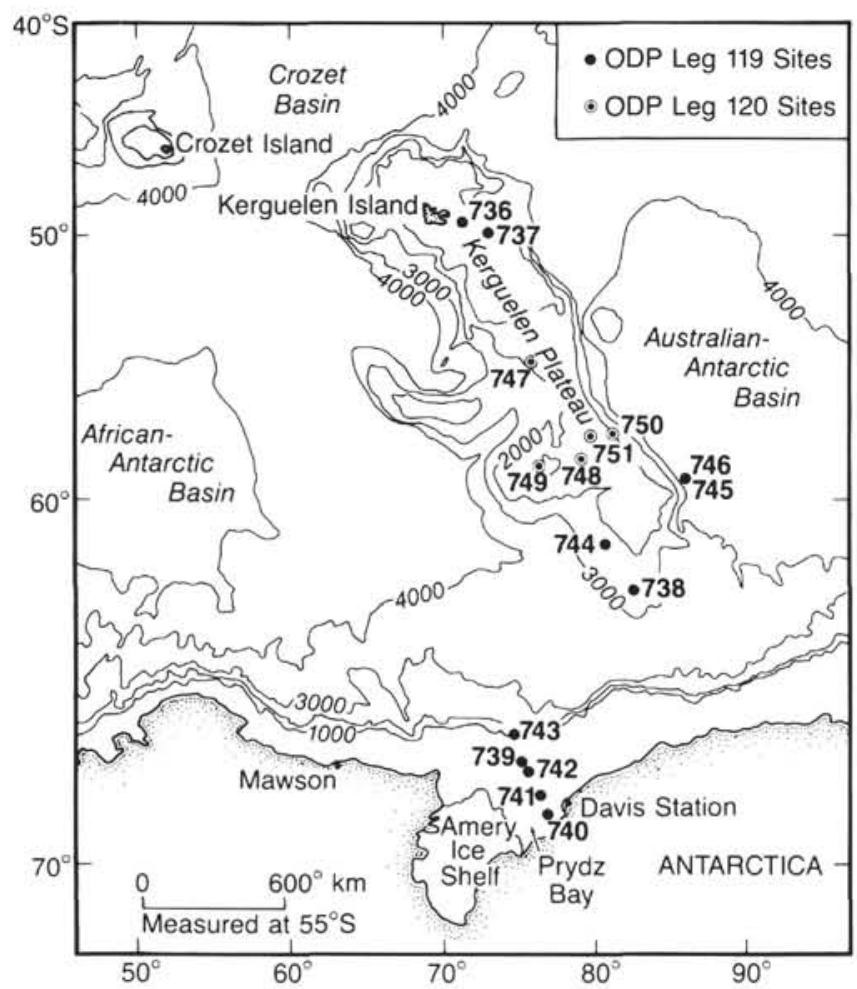

Figure 1. Map showing the location of Leg 119 and 120 sites on the Kerguelen Plateau.

\section{SOUTHERN OCEAN AND ANTARCTIC DIATOM BIOSTRATIGRAPHY}

\section{Existing Biostratigraphic References}

Existing literature on Oligocene to Holocene diatom biostratigraphy from previous Deep Sea Drilling Project (DSDP) and ODP legs to the Southern Ocean provides a wealth of information for taxonomic and biostratigraphic reference. However, given the large number of newly proposed diatom taxa and informal names (sp. A, sp., etc.), it is obvious that many diatom taxa are still poorly known stratigraphically, are lost in taxonomic uncertainty, or remain undiscovered. Reference literature for Oligocene to Recent diatom biostratigraphic studies from the Southern Ocean and from the Antarctic shelf/margin are presented in Tables 2 and 3, respectively. Older studies and reports of fossil diatoms from these regions, such as Van Heurck (1909), are not listed in these tables due to their general lack of biostratigraphic information. Reference to these older works can be found in the cited papers. The development of southern high-latitude diatom biostratigraphy is reviewed in papers by Weaver and Gombos (1981), Barron (1985b), Fenner (1985), and Baldauf and Barron (1991).

\section{Leg 120 Diatom Zonal Scheme}

As a result of the above 20 years of southern high-latitude diatom biostratigraphic study, a clear picture of diatom biostratigraphy has been established. Detailed dating of the biostratigraphic events is a fairly recent result of ODP continuous coring and advanced hydraulic piston corer (APC) recovery, which allow magnetostratigraphic division for reliable correlation of widely spaced records. Consistent age patterns of diatom events, deduced by associated microfossil, magnetostratigraphic, and isotopic age controls, indicate that a regional, highly refined diatom stratigraphy is possible and warranted for the Southern Ocean. The details of species diachroneity between the Antarctic Shelf and Southern Ocean, however, and changes in the strength of biogeographic barriers through time require further attention (Harwood, 1991; Harwood et al., 1989a). Future drilling on the Antarctic continental shelf will address many of these problems directly.

A high-resolution diatom biostratigraphic zonation is presented here for the Oligocene to Pleistocene, where 44 zones and subzones divide the last $36 \mathrm{Ma}$ (Fig. 3). The proposed diatom zonation is built upon an existing biostratigraphic framework developed over the past 20 years of Southern Ocean and Antarctic deep-sea coring and drilling (Tables 2 and 3). The progressive development of this biostratigraphic scheme is outlined in Figures 4 and 5. After recent advances from Legs 113, 114, 119 and 120 diatom biostratigraphic studies (Gersonde and Burckle, 1990; Fenner, in press; Baldauf and Barron, 1991; and this paper), the zonal framework is beginning to stabilize. In many cases, numerical ages and magnetostratigraphic correlatives may be confidently assigned to the respective zones. In other stratigraphic intervals where few good reference sections exist, the calibration will undoubtedly require future adjustment. We propose several new zones and subzones that subdivide existing "long" intervals of low stratigraphic resolution. In many cases, the new zones are based on diatom datums that were recognized for their biostratigraphic utility and used in earlier zonal schemes. The zonation employed here is based largely on "first appearance datum" levels (FAD). Approximately $80 \%$ of the 33 zones are based on FADs, with all 10 of the subzonal divisions defined by LADs (last appearance datum levels). The use of FADs minimizes the confusion associated with microfossil reworking that is prevalent in the Southern Ocean (Schrader, 1976; DeFelice and Wise, 1981). However, some stratigraphic intervals, such as the upper Pleistocene, bear only last occurrences (Fig. 3). Several datums are defined by the first or last abundant appearance of a particular taxon. In this paper an abundant appearance or disappearance was not quantitatively determined, because sample spacing was sufficiently great to readily notice when the abundance of a species was increased by at least an order of magnitude.

Potential age resolution afforded by the high-diversity diatom assemblages of the Southern Ocean ranks among the highest of all fossil groups. In addition to the $\mathbf{4 6}$ datum levels that define the diatom zones and subzones, the approximate stratigraphic level, age, and magnetic anomaly correlative of more than 150 other diatom datums are determined or estimated. This results in a total of 73 datum levels in the Pliocene/Pleistocene, 67 datum levels for the Miocene, and 45 


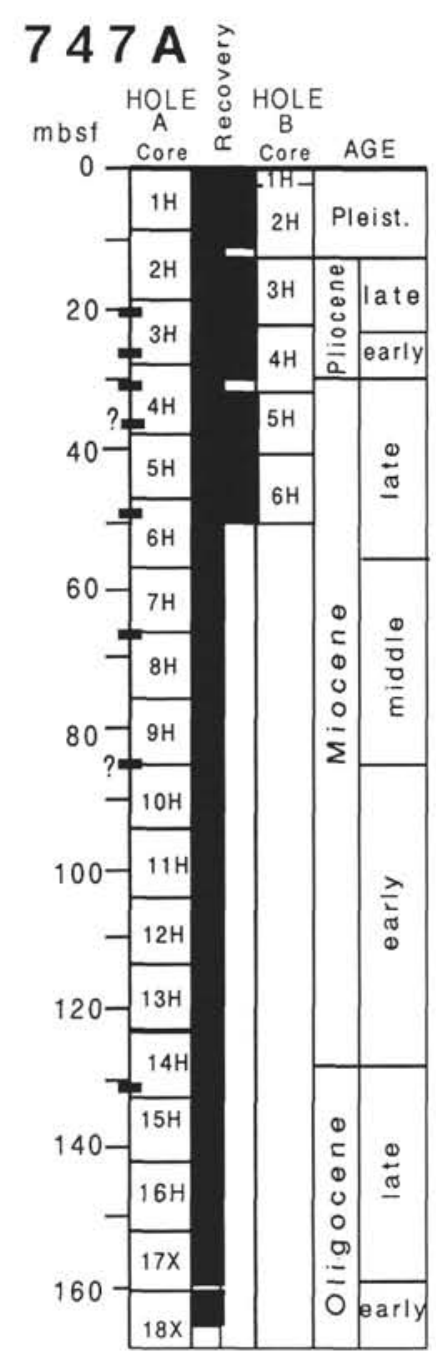

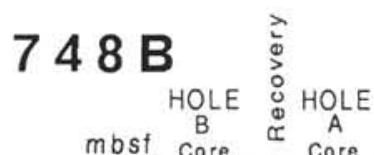

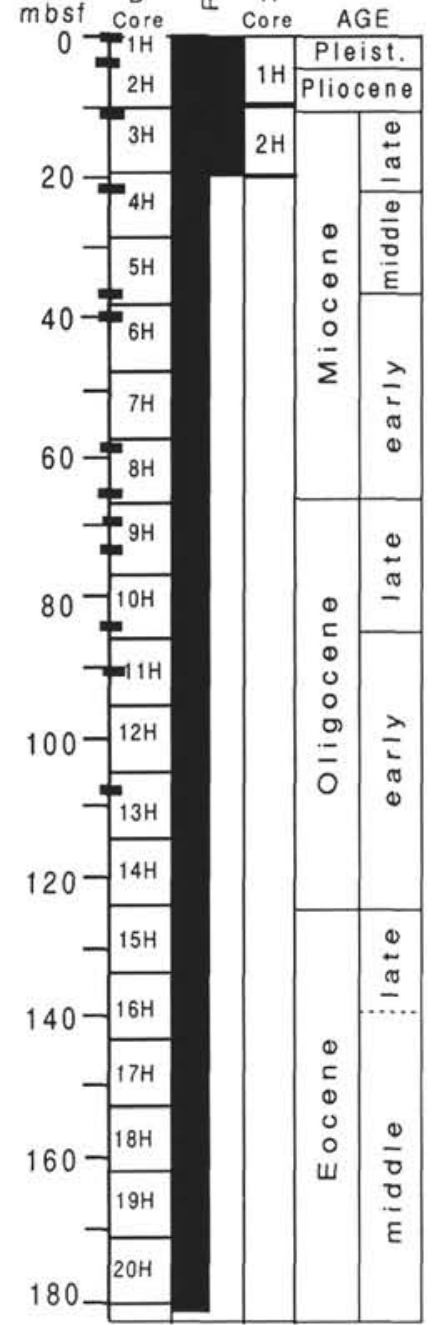

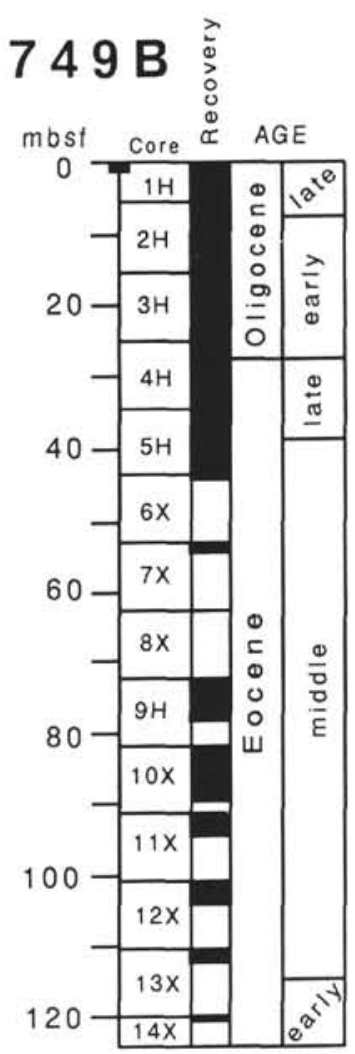

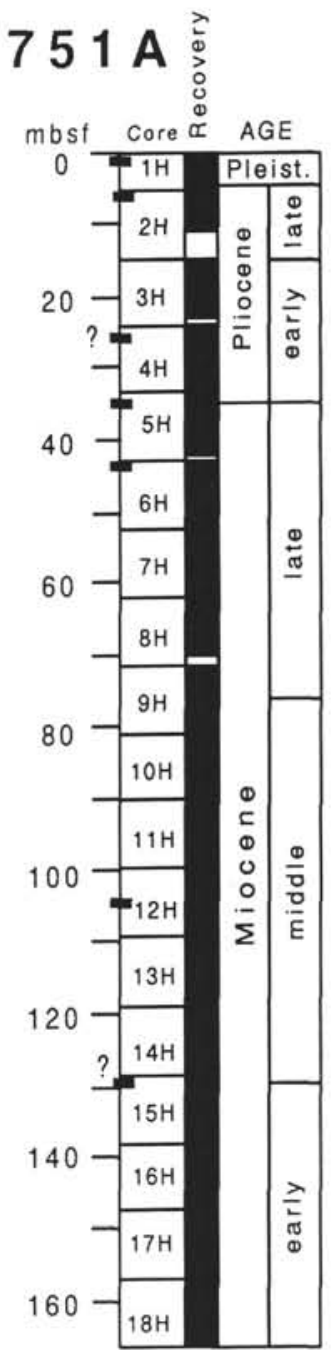

Figure 2. Summary of ages, and core recovery of Oligocene to Holocene sediments recovered during Leg 120.

datum levels for the Oligocene. Greater stratigraphic resolution is still possible as less common and poorly documented species become better known.

Ages for these zones were determined from the Berggren et al. $(1985 \mathrm{a}, \mathrm{b})$ time scale with reference to magnetostratigraphic polarity events (Heider, et al., this volume; Inokuchi and Heider, this volume). Magnetostratigraphic nomenclature generally follows that proposed by Tauxe et al. (1984), and reversed polarity intervals are similarly numbered in descending order within each chron.

A composite sequence of diatom biostratigraphic events is produced at the end of this paper through the incorporation of all Leg 120 data and other existing data (largely that from Legs 113 and 119). The large number of nonzonal diatom biostratigraphic events through the Oligocene to Pleistocene suggests that a much finer biostratigraphic subdivision will be possible in the future, as the ranges of the "minor" species become better known, and newly proposed species are documented from previously studied DSDP and ODP sections. The successful application of the new zones in other stratigraphic records in the Southern Ocean, as well as the continuing success of the existing framework indicates that the present zonation will have wide application. Further testing and review of the Oligocene to lower Miocene portion of this zonation is still required, however, with continued study of existing and new stratigraphic sections. It is our belief that the resolution demonstrated in the upper Neogene (1-2 zones/ m.y.) will be matched in the Paleogene with future work.

An Appendix contains taxonomic references for diatom species identified from Leg 120 sediments.

\section{METHODS}

Samples used in this study are from the same sample set used for the silicoflagellate and sponge spicule papers in this volume (McCartney and Harwood, this volume). Raw samples were prepared as smear slides when diatoms occurred in abundances $\sim 50 \%$ of the microfossils. Lower values of diatom abundance required chemical treatment with $\mathrm{H}_{2} \mathrm{O}_{2}$ and $\mathrm{HCl}$ to concentrate the siliceous fossils. Strewn slides were then prepared after the residues were washed of these chemicals. Because of this differential processing technique through various intervals, the estimated abundances presented in the distribution tables are only of relative abundance and certainly qualitative. Future analysis for quantitative 
Table 2. History of Neogene diatom biostratigraphic studies in the Southern Ocean and Antarctic region.

\begin{tabular}{|c|c|c|}
\hline Authors & Ages & Region/Project/Sites \\
\hline Jousé et al. (1963) & Pliocene to Pleistocene & between Africa and Antarctica (piston cores) \\
\hline Donahue $(1967,1970)$ & upper Pliocene to Pleistocene & south Pacific Ocean (piston cores) \\
\hline Hays and Donahue (1972) & upper Pliocene to Pleistocene & south Pacific Ocean (piston cores) \\
\hline Abbott (1974) & Pleistocene & southeast Indian Ocean (piston cores) \\
\hline McCollum (1975) & lower Oligocene to Pleistocene & Southern Ocean and Antarctic margin/DSDP Leg 28 \\
\hline Hajos (1976) & upper Eocene to lower Oligocene & southwest Pacific Ocean/DSDP Leg 29 \\
\hline Schrader (1976) & Oligocene to Pleistocene & southeast Pacific Ocean/DSDP Leg 35 \\
\hline Gombos (1977) & upper Paleocene to Pleistocene & southern Atlantic Ocean/DSDP Leg 36 \\
\hline Ciesielski and Wise (1977) & miscellaneous Cenozoic ages & Falkland Plateau (piston cores) \\
\hline Weaver and Gombos (1981) & upper Paleocene to Pleistocene & Southern Ocean/DSDP Legs $28,29,35,36$ \\
\hline Ciesielski et al. (1982) & upper Miocene to Pleistocene & Southern Ocean (piston cores) \\
\hline Burckle and Abrams (1987) & upper Miocene to Pleistocene & Southern Ocean (piston cores) \\
\hline Gombos and Ciesielski (1983) & upper Eocene to lower Miocene & southern Atlantic Ocean/DSDP Leg 71 \\
\hline Ciesielski (1983) & upper Miocene to Pleistocene & southern Atlantic Ocean/DSDP Leg 71 \\
\hline Gombos (1983a) & middle Eocene & southern Atlantic Ocean/DSDP Leg 71 \\
\hline Gombos (1983b) & upper Oligocene and lower Miocene & southern Atlantic Ocean/DSDP Leg 72 \\
\hline Fenner (1984a, 1984b, 1985) & Eocene and Oligocene & southern Pacific and Atlantic oceans \\
\hline Ciesielski (1986) & middle Miocene to Quaternary & southwest Pacific Ocean/DSDP Leg 90 \\
\hline Gersonde and Burckle (1990) & lower Miocene to Holocene & Weddell Sea/ODP Leg 113 \\
\hline Fenner (in press) & upper Pliocene to Holocene & southern Atlantic Ocean/ODP 114 \\
\hline Baldauf and Barron (1991) & Oligocene to Holocene & Kerguelen Plateau and Prydz Bay/ODP Leg 119 \\
\hline
\end{tabular}

Table 3. History of upper Paleogene diatom biostratigraphic studies in the Southern Ocean and Antarctic region.

\begin{tabular}{|c|c|c|}
\hline Authors & Ages & Region/Project/Sites \\
\hline McCollum (1975) & upper Oligocene to Pleistocene & Ross Sea/DSDP Leg 28 \\
\hline Savage and Ciesielski (1983) & upper Oligocene to Pleistocene & Ross Sea/DSDP Leg 28 \\
\hline Steinhauff et al. (1987) & upper Oligocene to Pleistocene & Ross Sea/DSDP Leg 28 \\
\hline Brady (1979); Harwood (1986a) & upper Miocene to Pleistocene & western Ross Sea, McMurdo Sound region DVDP 10, 11 \\
\hline Akiba (1982); Koizumi (1982) & Pleistocene & Bellingshausen Sea (piston cores) \\
\hline Macchiavello and Lange (1980) & Pliocene to Pleistocene & Weddell Sea region (piston cores) \\
\hline Barron and Burckle (1987) & Pleistocene & Ross Sea/S. P. Lee cruise \\
\hline Denton et al. (1984, in press) & upper Miocene and lower Pliocene & Wright Valley, Southern Victoria Land \\
\hline Harwood (1986a) & lower Pliocene & Vestfold Hills, Marine Plain diatomaceous sands \\
\hline Harwood (1986a) & upper Pliocene/lower Pleistocene & Cockburn Island, Pecten Conglomerate \\
\hline Harwood (1986a) & lower Pliocene to Pleistocene & western Ross Sea, McMurdo Sound region/CIROS-2 \\
\hline Harwood (1986b) & upper Oligocene to lower Miocene & western Ross Sea, McMurdo Sound region/MSSTS-1 \\
\hline Harwood (1989) & lower Oligocene to lower Miocene & western Ross Sea, McMurdo Sound region/CIROS-1 \\
\hline Harwood et al. (1989a) & lower Oligocene to lower Miocene & western Ross Sea, McMurdo Sound region/CIROS-1 \\
\hline Baldauf and Barron (1991) & lower Oligocene to Pliocene & Prydz Bay ODP Leg 119 \\
\hline Brady and Martin (1979) & multiple Cenozoic ages (recycled) & RISP Site $\mathrm{J} / 9$ \\
\hline Kellogg and Kellogg (1986) & multiple Cenozoic ages (recycled) & RISP Site $\mathrm{J} / 9$ \\
\hline Harwood et al. (1989b)* & multiple Cenozoic ages (recycled) & RISP Site J/9 \\
\hline Scherer et al. (1989) & multiple Cenozoic ages (recycled) & West Antarctic subglacial basins, Crary Ice Rise \\
\hline Scherer (1989) & multiple Cenozoic ages (recycled) & Ice stream B \\
\hline Harwood (1986a, 1986c, in press)* & multiple Cenozoic ages (recycled) & East Antarctic subglacial basins \\
\hline
\end{tabular}

*and references therein.

abundance stratigraphy is warranted on all of these materials. Abundance values presented in the distribution table are based on the following scale:

Rare $(R)=$ one specimen of a particular species encountered in 5-20 fields of view using a $40 \times$ objective and $10 \times$ ocular;

Frequent $(F)=$ one specimen encountered in every 5 fields of view;

Common $(C)=$ one specimen in every field of view; and view.

Abundant $(A)=$ more than one specimen in every field of

Harwood bears principal responsibility for the PliocenePleistocene and Eocene-Oligocene biostratigraphy in this paper, and Maruyama bears principal responsibility for the Miocene biostratigraphy.

Type specimens of new diatom taxa will be curated in the U.S. National Museum, Washington, D.C., and in the Museum of Yamagata University. The following section describes the biostratigraphic zonal scheme employed herein and concludes with a description of how the zones are applied at each site.

\section{DEFINITION OF DIATOM ZONES}

Thalassiosira lentiginosa Partial Range Zone

Authors. McCollum (1975), renamed by Kellogg and Kellogg (1986).

Top. LO of Thalassiosira lentiginosa (i.e., Holocene).

Base. LO of Actinocyclus ingens.

Stratigraphic position and age. upper Pleistocene to Holocene, $0-0.62 \mathrm{Ma}$.

Paleomagnetic correlation. The base of this zone occurs near the bottom of Subchron C1N-1 (Brunhes) as discussed in Ciesielski (1983) and borne out in later works.

\section{Actinocyclus ingens Partial Range Zone}

Authors. Gersonde and Burckle (1990), base modified herein.

Top. LO of Actinocyclus ingens, as employed by McCollum for his Coscinodiscus elliptiporalA . ingens Zone.

Base. LO of Nitzschia barronii. 
AGE DIATOM ZONES

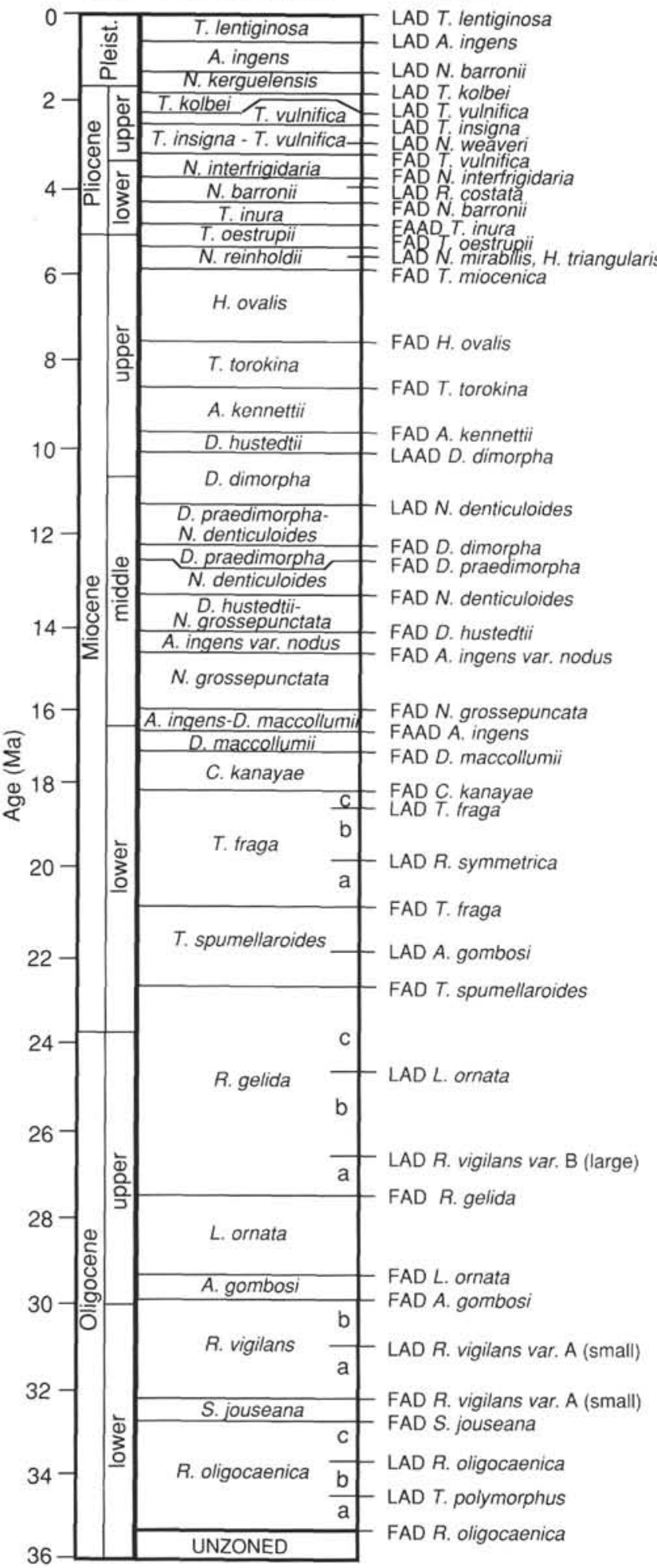

Figure 3. Diatom biostratigraphic zonation used in this study.

Stratigraphic position and age. Pleistocene, $0.62-1.25 \mathrm{Ma}$.

Paleomagnetic correlation. This zone ranges from the lower portion of Subchron C1N-1 down to the middle of Subchron C2R-2.

Discussion. This zone is equivalent to the upper portion of the $A$. ingens Zone of Gersonde and Burckle (1990), which we divided into two zones by the LO of $N$. barronii. This zone is also equivalent to the upper portion of the Coscinodiscus elliptiporalActinocyclus ingens Zone of McCollum (1975).

\section{Nitzschia kerguelensis Partial Range Zone}

Authors. Harwood and Maruyama (this paper).

Top. LO of Nitzschia barronii.

Base. LO of Thalassiosira kolbei.

Stratigraphic position and age. lower Pleistocene to uppermost Pliocene, 1.25-1.8 Ma.

Paleomagnetic correlation. This zone ranges from the middle of Subchron C2R-2 down to just above, or within, the upper portion of Subchron $\mathrm{C} 2 \mathrm{~N}-2$ (Olduvai) in Hole $747 \mathrm{~A}$.

Discussion. This zone is equivalent to the lower portion of the Actinocyclus ingens Zone of Gersonde and Burckle (1990), which we subdivided into two zones ( $A$. ingens and $N$. kerguelensis) by the LO of $N$. barroni. The $N$. kerguelensis Zone also includes the interval represented by the Rhizosolenia (Simonseniella) barboi Zone of Baldauf and Barron (1991) and the R. barboi/N. kerguelensis Zone of McCollum (1975). Following the Gersonde and Burckle (1990) zonation, we did not recognize the Rhizosolenia barboi Zone because of the rare to trace occurrence of the nominative species in the uppermost Pliocene and lower Pleistocene on Kerguelen Plateau. The highest occurrence of Rhizosolenia barboi is noted in most Leg 120 holes between 3.0 and $3.4 \mathrm{Ma}$ and not as young as $\sim 1.6 \mathrm{Ma}$, as required for sequential application of the $R$. barboi Zone in the existing zonal schemes. This new zone is not the same as the $N$. kerguelensis Zone of Donahue (1970) or Abbott (1974).

\section{Thalassiosira kolbei Partial Range Zone}

Author. Ciesielski (1983), renamed by Baldauf and Barron (1991).

Top. LO of Thalassiosira kolbei.

Base. LO of Thalassiosira vulnifica.

Stratigraphic position and age. uppermost Pliocene, 1.8-2.2 Ma.

Paleomagnetic correlation. This zone ranges from just above, or within, the upper portion of Subchron $\mathrm{C} 2 \mathrm{~N}-2$ (Olduvai) down to the middle of Subchron C2R-4 (basal Matuyama).

Discussion. This zone has its origin in the Coscinodiscus kolbeiRhizosolenia barboi Zone of McCollum (1975), the base of which was redefined by Weaver and Gombos (1981). Ciesielski (1983) subdivided Weaver and Gombos" zone into the $C$. kolbei-R. barboi and $C$. vulnificus zones by the highest occurrence of $C$. vulnificus. Baldauf and Barron (1991) and this paper continue Ciesielski's use of these two zones by the recognition of the Thalassiosira kolbei and Thalassiosira vulnifica zones (also note the generic transfer of the nominative taxa in these two zones). Gersonde and Burckle (1990) offer a new name, Thalassiosira kolbei Zone, for the zone as defined by Weaver and Gombos (1981). The T. kolbei Zone of Gersonde and Burckle (1990) includes both the $T$. kolbei and $T$. vulnifica zones as employed herein and in Baldauf and Barron (1991).

\section{Thalassiosira vulnifica Partial Range Zone}

Authors. Ciesielski (1983), renamed by Fenner (in press).

Top. LO of Thalassiosira vulnifica.

Base. LO of Thalassiosira insigna (Jousé) $\mathrm{n}$. comb.

Stratigraphic position and age. upper Pliocene, 2.2-2.5 Ma.

Paleomagnetic correlation. The base of this zone occurs near the Chron C2/C2A (Gauss/Matuyama) boundary, or just above it, according to McCollum (1975), Weaver and Gombos (1981), and Ciesielski (1983). The base of this zone was not recognized because of a hiatus that was present in all Leg 120 holes.

Discussion. This zone correlates to the lower portion of the $C$. kolbei-R. barboi Zone of McCollum (1975) and Weaver and Gombos (1981), and to the lower portion of the T. kolbei Zone of Gersonde and Burckle (1990).

\section{Thalassiosira insigna-Thalassiosira vulnifica Concurrent Range Zone}

Authors. Harwood and Maruyama (this paper).

Top. LO of Thalassiosira insigna (Jousé) n. comb.

Base. FO of Thalassiosira vulnifica.

Stratigraphic position and age. lower upper Pliocene, 2.5-3.1 Ma. Paleomagnetic correlation. This zone ranges from near the Chron $\mathrm{C} 2 / \mathrm{C} 2 \mathrm{~A}$ (Gauss/Matuyama) boundary down to within Subchron C2A-3.

Subzones. This zone is divided into Subzones " $a$ " and "b" by the highest occurrence of Nitzschia weaveri. Upper Subzone " $b$ " is 


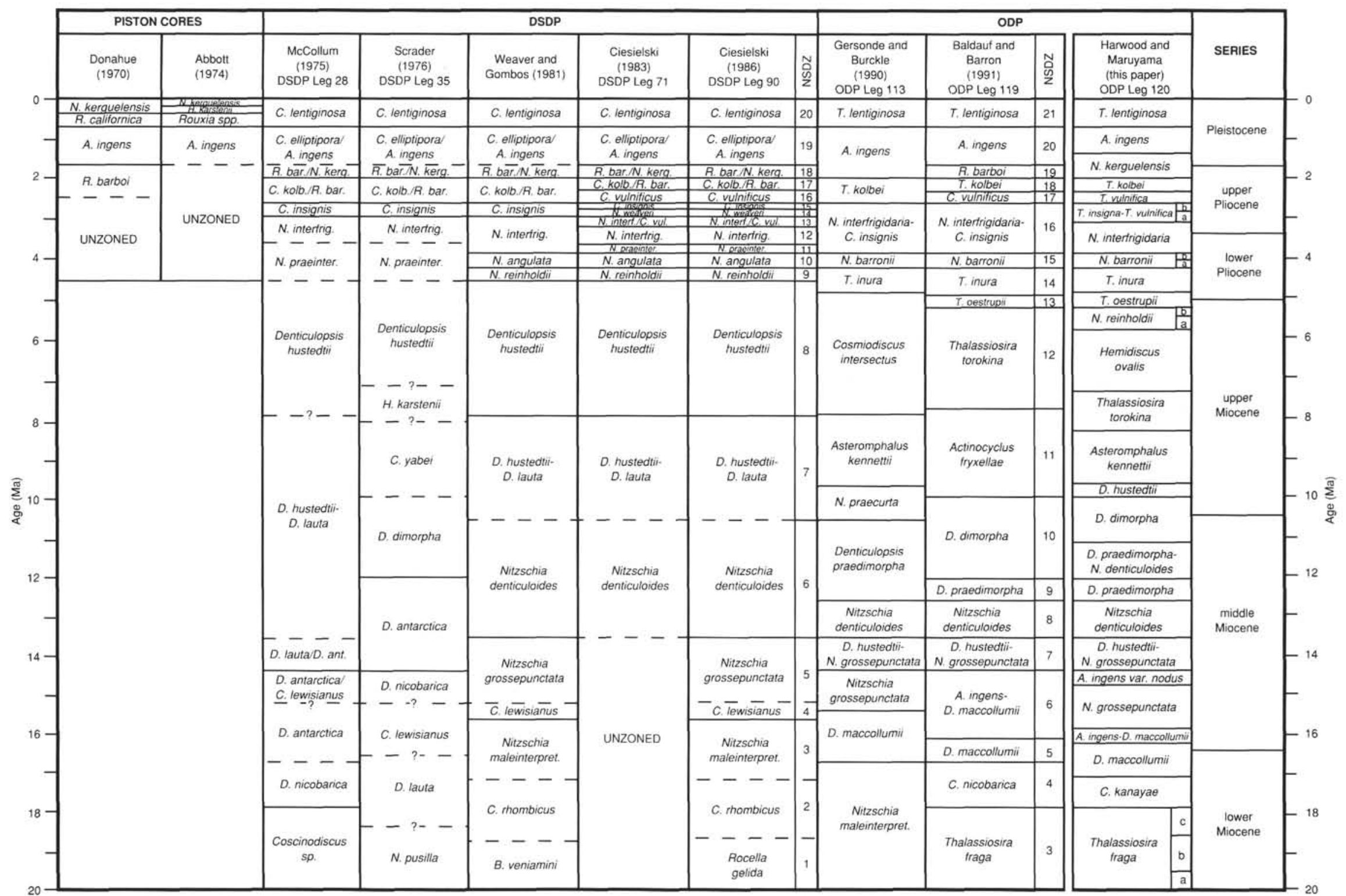

Figure 4. History of Neogene diatom zonations for the Southern Ocean and Antarctic area since 1975 showing the progressive division of geologic time and stability of the zonation (modified from Baldauf and Barron, 1991). 


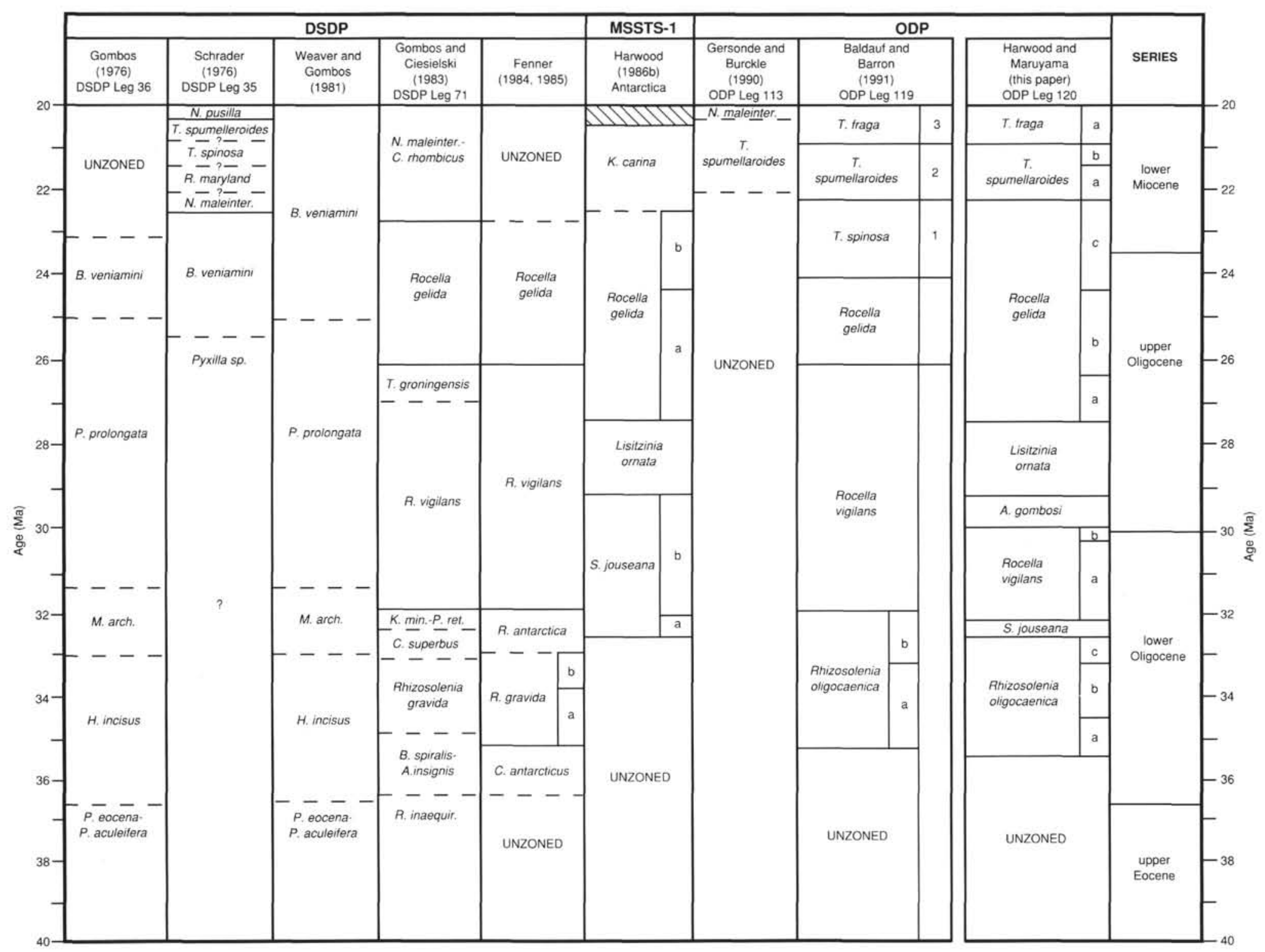

Figure 5. History of late Eocene to Oligocene diatom zonations for the Southern Ocean (modified from Baldauf and Barron, 1991). 
equivalent to the Cosmiodiscus insignis Zone of Ciesielski (1983). Lower Subzone " $a$ " is equivalent to the upper portion of the Nitzschia weaveri Zone of Ciesielski (1983).

Discussion. This concurrent range zone marks the transition from the overlying zones that are exclusively defined by LO datums to the underlying zones that are defined predominantly by FO datums. This zone differs from existing schemes in that it uses the $\mathrm{FO}$ of $T$. vulnifica rather than the slightly younger LO of Nitzschia interfrigidaria as a zonal datum. It is equivalent to (1) the $C$. insignis Zone and upper portion of the $N$. interfrigidaria Zone, as proposed by McCollum (1975); (2) to the $C$. insignis, $N$. weaveri, and $N$. interfrigidaria-C. vulinificus zones of Ciesielski (1983); and (3) to the upper portion of the $N$. interfrigidaria-C. insignis Zone of Gersonde and Burckle (1990).

The FO of Thalassiosira vulnifica may be diachronous between various regions of the Southern Ocean, or different taxonomic interpretations may influence the reported ranges. Because of these problems, Gersonde and Burckle (1990) decided not to use this datum and note a younger age than reported here. We note that small forms of Thalassiosira fasciculata $\mathrm{n}$. sp. may be confused with T. vulnifica. Ciesielski (1983) places the FO of $T$. vulnifica at $3.1 \mathrm{Ma}$; Baldauf and Barron place the FO between 2.7 and 2.8 Ma. Further work is needed to determine if this species is diachronous or whether the apparent age differences result from different methodologic or taxonomic concepts.

\section{Nitzschia interfrigidaria Partial Range Zone}

Authors. McCollum (1975); modified in Weaver and Gombos (1981) and modified further herein.

Top. FO of Thalassiosira vulnifica.

Base. FO of Nitzschia interfrigidaria.

Stratigraphic position and age. lowermost upper Pliocene down to upper lower Pliocene, 3.1-3.6 Ma.

Paleomagnetic correlation. This zone ranges from Subchron C2AN-3 down to the middle of Subchron C3R-1, spanning the Gauss/Gilbert boundary.

Discussion. Weaver and Gombos (1981) redefined the lower boundary of McCollum's (1975) N. interfrigidaria Zone based on the FO of $N$. interfrigidaria, a concept that we follow. We draw the upper boundary of McCollum's zone at the FO of T. vulnifica, as Ciesielski (1983) suggests for his $N$. interfrigidaria Zone. Gersonde and Burckle (1990) also define the base of their $N$. interfrigidaria-C. insignis Zone at the FO of $N$. interfrigidaria.

\section{Nitzschia barronii Partial Range Zone}

Authors. Weaver and Gombos (1981); renamed by Gersonde and Burckle (1990).

Top. FO of Nitzschia interfrigidaria.

Base. FO of Nitzschia barronii.

Stratigraphic position and age. lower Pliocene, 3.6-4.1 Ma.

Paleomagnetic correlation. This zone ranges from the middle of Subchron C3R-1 down to Subchron C3N-2.

Subzones. Two subzones are distinguished within the $N$. barronii Zone, divided by the LO of Rhizosolenia costata at a level near the base of Subchron C2AR-1.

Discussion. Gersonde and Burckle (1990) question whether Weaver and Gombos' (1981) $N$. angulata is conspecific with their $N$. barronii and, thus, whether the base of the $N$. barronii Zone is equivalent to the base of the Weaver and Gombos (1981) N. angulata Zone. A preliminary draft copy of the Weaver and Gombos (1981) paper, given to Harwood in 1980, included plates of photomicrographs that were not published. In these plates, Weaver and Gombos illustrate specimens they refer to as $N$. angulata that fall under Gersonde's (in press) concept of $N$. barronii. Thus, the Gersonde and Burckle (1990) N. barronii Zone is not a new zone, but a new name for the Nitzschia angulata Zone of Weaver and Gombos (1981).

\section{Thalassiosira inura Partial Range Zone}

Authors. Gersonde and Burckle (1990).

Top. FO of Nitzschia barronii.

Base. FO of Thalassiosira inura.

Stratigraphic position and age. lower Pliocene, 4.1-4.5 (4.8?) Ma.

Paleomagnetic correlation. This zone ranges from Subchron $\mathrm{C} 3 \mathrm{~N}-2$ down to Subchron $\mathrm{C} 3 \mathrm{~N}-3$.
Discussion. The base of this zone is not present in Leg 120 materials. Age and stratigraphic information is taken from Harwood (1986a), Gersonde and Burckle (1990) and Baldauf and Barron (1991). Different taxonomic concepts of $T$. inura confuse the accurate determination of the age of the LO of $T$. inura, which has been referred to as $T$. jacksonii and $T$. gracilis in past works. Reports of this taxon in the uppermost Miocene are probably misidentifications of $T$. jacksonii or a related species.

\section{Thalassiosira oestrupii Partial Range Zone}

Authors. Baldauf and Barron (1991).

Top. FO of Thalassiosira inura.

Base. FO of Thalassiosira oestrupii.

Stratigraphic position and age. lower Pliocene to uppermost Miocene, 4.5(4.8)-5.1 Ma.

Paleomagnetic correlation. This zone ranges from the middle to base of Subchron C3N-3 down to the base of Subchron C3R-4.

Discussion. We elevate to zonal level Subzone "b" of the $T$. torokina Zone, as proposed by Baldauf and Barron (1991) for the interval between the lowest occurrences of $T$. inura and $T$. oestrupii. Both Gersonde and Burckle (1990) and Baldauf and Barron (1991) note the stratigraphic value of this species in the uppermost Miocene. This zone is not present in Leg 120 materials. Age and stratigraphic information is taken from Harwood (1986a), Gersonde and Burckle (1990), and Baldauf and Barron (1991).

\section{Nitzschia reinholdii Partial Range Zone}

Authors. Harwood and Maruyama (this paper).

Top. FO of Thalassiosira oestrupii.

Base. FO of $T$. miocenica.

Stratigraphic position and age. uppermost Miocene, 5.1-5.8 Ma.

Paleomagnetic correlation. This zone spans the interval from near the base of the Gilbert (Subchron C3R-4 base) down to the middle of Subchron C3AN-2.

Subzones. Two subzones are distinguished within the $N$, reinholdii Zone and divided by the joint LO of Neobrunia mirabilis with Hemidiscus triangularus at a level near the top of Subchron C3AN-1.

Discussion. This zone is poorly represented in Leg 120 materials; stratigraphic information to define this zone draws from the papers by Ciesielski (1983, 1986), Gersonde and Burckle (1990) and Baldauf and Barron (1991). It is not equivalent to the existing $N$. reinholdii zones of the Pliocene and Pleistocene previously proposed by Burckle (1972) in the equatorial Pacific and Weaver and Gombos (1981) in the lower Pliocene of the Southern Ocean. Baldauf and Barron (1991) indicate an age of $\sim 5.8 \mathrm{Ma}$ for the FO of T. miocenica in the Southern Ocean. The FO of $N$. reinholdii may approximate the base of this zone, but confusion with other species and its diachronous, older first appearance in the equatorial Pacific at $\sim 7.3 \mathrm{Ma}$ (Barron, pers. comm. to D. Harwood, 1990) is a concern.

\section{Hemidiscus ovalis Partial Range Zone}

Authors. Harwood and Maruyama (this paper).

Top. FO of Thalassiosira miocenica.

Base. FO of Hemidiscus ovalis.

Stratigraphic position and age. upper Miocene, 5.8-7.9 Ma.

Paleomagnetic correlation. This zone ranges from Subchron C3AN-2 down to the base of Chron C4.

Discussion. This zone and the bordering $N$, reinholdii and $T$. torokina zones subdivide the existing "long" zones of the upper Miocene, which include the Denticula hustedtii Zone of McCollum (1975), the Cosmiodiscus intersectus Zone of Gersonde and Burckle (1990) and the T. torokina Zone of Baldauf and Barron (1991). This zone is poorly represented in ODP Leg 120 materials. Stratigraphic information to define this zone is taken largely from the data in Gersonde and Burckle (1990), and Baldauf and Barron (1991).

\section{Thalassiosira torokina Partial Range Zone}

Authors. Baldauf and Barron (1991), modified herein.

Top. FO of Hemidiscus ovalis (Gersonde) n. comb.

Base. FO of Thalassiosira torokina.

Stratigraphic position and age. middle upper Miocene, 7.9-8.2 (8.6) Ma.

Paleomagnetic correlation. This zone spans the interval from near the base of the lowest normal event in Subchron C4 down to the base of, or just below, Subchron C4AN-2. 
Discussion. We find the FO of Thalassiosira torokina, which defines the base of this zone, at a lower stratigraphic level $(\sim 8.6 \mathrm{Ma})$ in Hole 747A than previously reported by Ciesielski (1983) ( $\sim 6 \mathrm{Ma})$, and Baldauf and Barron (1991) (7.7 Ma). This zone correlates with the lower portion of the $T$. torokina Zone of Baldauf and Barron (1991), the lower portion of the $C$. intersectus Zone of Gersonde and Burckle (1990), and the D. hustedtii Zone of Weaver and Gombos (1981).

\section{Asteromphalus kennettii Partial Range Zone}

Authors. Gersonde and Burckle (1990), modified herein.

Top. FO of Thalassiosira torokina.

Base. FO of Asteromphalus kennettii. Ma

Stratigraphic position and age. lower upper Miocene, 8.2 (8.6)-9.6

Paleomagnetic correlation. This zone ranges from within the lower portion of Chron C4A down to the middle of Chron C5.

Discussion. Ciesielski (1983) documents the FO of this species (referred to as Asteromphalus sp. 1) at $\sim 9.3 \mathrm{Ma}$ in DSDP Hole 513A.

\section{Denticulopsis hustedtii Interval Zone}

Authors. Harwood and Maruyama (this paper).

Top. FO of Asteromphalus kennettii.

Base. Last abundant occurrence of Denticulopsis dimorpha.

Stratigraphic position and age. lower upper Miocene, 9.6-10.1 Ma.

Paleomagnetic correlation. This zone occurs within the middle of the long normal polarity interval of Chron C5.

Discussion. Baldauf and Barron (1991) note the distinct stratigraphic gap, which defines this new zone, between the last common occurrence of $D$. dimorpha and the FO of $A$. kennettii. As defined here, the base of this zone has potential for limited reproducibility in other regions of the Southern Ocean due to diachronous abundance fluctuations and effects of dissolution. Future work should strive to define this datum more quantitatively. Gersonde and Burckle (1990) place the top of the $D$. dimorpha acme at $9.8 \mathrm{Ma}$; Baldauf and Barron (1991) place the last common occurrence of $D$. dimorpha at $9.9 \mathrm{Ma}$.

\section{Denticulopsis dimorpha Partial Range Zone}

Authors. Baldauf and Barron (1991), modified herein.

Top. Last abundant occurrence of Denticulopsis dimorpha.

Base. LO of Nitzschia denticuloides, usually still in the presence of Denticulopsis praedimorpha.

Stratigraphic position and age. lowest upper Miocene to uppermost middle Miocene, 10.1-11.3 Ma.

Paleomagnetic correlation. This zone ranges from within the lower one-third of Subchron C5N-1 down to near, or slightly below, the base of Subchron C $5 \mathrm{~N}-3$.

Discussion. This zone is equivalent to the upper portion of the $D$. dimorpha Zone of Baldauf and Barron (1991), which we have divided into two zones $(D$. dimorpha and $D$. praedimorpha- $N$. denticuloides by the LO of $N$. denticuloides. This datum is approximated by the LO of $D$. praedimorpha, which ranges slightly higher in most sections. This zone is also equivalent to the lower portion of the $N$. praecurta Zone and the upper portion of the D. praedimorpha Zone of Gersonde and Burckle (1990). In the absence of a reliable datum for the last $N$. denticuloides, the last $D$. praedimorpha could approximate the base of this zone; all available stratigraphic records show the LO of $D$. praedimorpha to range slightly higher $(\sim 0.1 \mathrm{Ma})$ than the LO of $N$ denticuloides. Weaver and Gombos (1981) recognize the value of the LO of $N$. denticuloides as a good datum level, using it to define the top of their $N$. denticuloides Zone.

\section{Denticulopsis praedimorpha-N. denticuloides Partial Range Zone}

Authors. Harwood and Maruyama (this paper).

Top. LO of Nitzschia denticuloides.

Base. FO of Denticulopsis dimorpha.

Stratigraphic position and age. upper middle Miocene, 11.3-11.9 (12.2) Ma.

Paleomagnetic correlation. This zone ranges from just below Subchron $\mathrm{C} 5 \mathrm{~N}-3$ to Subchron C5A.

Discussion. This zone is equivalent to the lower portion of the $D$. dimorpha Zone of Baldauf and Barron (1991). This zone is also equivalent to the upper portion of the $D$. praedimorpha Zone of Gersonde and Burckle (1990), although the top of Gersonde and Burckle's zone ranges slightly higher.

\section{Denticulopsis praedimorpha Partial Range Zone}

Authors. Gersonde and Burckle (1990), modified by Baldauf and Barron (1991).

Top. FO of Denticulopsis dimorpha.

Base. FO of Denticulopsis praedimorpha.

Stratigraphic position and age. middle middle Miocene, 11.9 (12.2)-12.6 Ma

Paleomagnetic correlation. This zone ranges from the top of Subchron C5AR-2 down to Subchron C5AN-4.

Discussion. Baldauf and Barron (1991) redefine the upper boundary of the D. praedimorpha Zone of Gersonde and Burckle (1990) using the FO of $D$. dimorpha rather than the LO of $D$. praedimorpha. Thus, the redefined zone is equivalent to the lower portion of Gersonde and Burckle's D. praedimorpha Zone.

\section{Nitzschia denticuloides Partial Range Zone}

Authors. Weaver and Gombos (1981), redefined by Gersonde and Burckle (1990).

Top. FO of Denticulopsis praedimorphá.

Base. FO of Nitzschia denticuloides.

Stratigraphic position and age. middle middle Miocene, 12.6-13.5 $\mathrm{Ma}$.

Paleomagnetic correlation. This zone ranges from Subchron C5AN-4 down to Subchron C5ABN.

Discussion. Gersonde and Burckle (1990) suggest new datum levels to define both the top and base of the Weaver and Gombos' zone. Weaver and Gombos define the base of this zone by the LO of $N$. grossepunctata, but they also state that the FO of $N$. denticuloides coincides with the base of the zone. Gersonde and Burckle (1990) redefine the base of this zone on the latter datum and suggest a new top. Both of these revisions are supported here in light of the preferred use of FO datum levels rather than LOs, because of problems with microfossil reworking. The redefined zone is equivalent to the lower portion of the original zone.

\section{Denticulopsis hustedtii-Nitzschia grossepunctata Partial Range Zone}

Authors. Gersonde and Burckle (1990).

Top. FO of Nitzschia denticuloides.

Base. FO of Denticulopsis hustedtii. $\mathrm{Ma}$.

Stratigraphic position and age. middle middle Miocene, 13.5-14.2

Paleomagnetic correlation. This zone ranges through the interval from Subchron C5ABN down to the top of Subchron C5DN.

\section{Actinocyclus ingens var. nodus Partial Range Zone}

Authors. Harwood and Maruyama (this paper)

Top. FO of Denticulopsis hustedtii.

Base. FO of Actinocyclus ingens var. nodus. $\mathrm{Ma}$

Stratigraphic position and age. middle middle Miocene, 14.2-14.5

Paleomagnetic correlation. This zone occurs within Subchron C5ADN.

\section{Nitzschia grossepunctata Partial Range Zone}

Authors: Gersonde and Burckle (1990), redefined herein.

Top. FO of Actinocyclus ingens var. nodus.

Base. FO of Nitzschia grossepunctata. $\mathrm{Ma}$.

Stratigraphic position and age. lower middle Miocene, 14.5- 15.5

Paleomagnetic correlation. This zone ranges from within Subchron C5ADN down to a level near the base of Subchron C5BR-2, just above the top of Subchron $\mathrm{C} 5 \mathrm{CN}-1$.

Discussion. We subdivide the $N$. grossepunctata Zone as defined by Gersonde and Burckle (1990) into two zones based on the FO of $A$ ingens var. nodus. Thus, our N. grossepunctata Zone is equivalent to the lower portion of the $N$. grossepunctata Zone of Gersonde and Burckle (1990). The base of this zone is not identified in any Leg 120 sites. Age information for the base of this zone is drawn from Gersonde and Burckle (1990) and Baldauf and Barron (1991).

Actinocyclus ingens-Denticulopsis maccollumii Partial Range Zone

Authors. Baldauf and Barron (1991), modified herein.

Top. FO of Nitzschia grossepunctata.

Base. First common occurrence of Actinocyclus ingens. 
Stratigraphic position and age. Spanning the middle and lower Miocene boundary, 15.5-16.4 Ma.

Paleomagnetic correlation. This short zone ranges from the lower portion of Subchron C5BR-2 to the upper part of Subchron C5CN-1.

Discussion. We insert this zone between the Nitzschia grossepunctata Zone and the $D$. maccollumii Zone in the zonal scheme of Gersonde and Burckle (1990). By using the A. ingens datum in this fashion, we reduce the stratigraphic extent of the $D$. maccollumii Zone. We defined the base of this zone by the first common occurrence of $A$. ingens because this species is known to occur at a lower stratigraphic position in the lower lower Miocene. This zone is not identified in any Leg 120 sites. Age information for the base of this zone is estimated from Gersonde and Burckle (1990) and Baldauf and Barron (1991).

\section{Denticulopsis maccollumii Partial Range Zone}

Authors. McCollum (1975), renamed by Gersonde and Burckle (1990) and redefined herein.

Top. First common occurrence of Actinocyclus ingens.

Base. FO of Denticulopsis maccollumii.

Stratigraphic position and age. uppermost lower Miocene, 16.417.0 Ma.

Paleomagnetic correlation. The top of this zone falls within the middle of Subchron $\mathrm{C} 5 \mathrm{CN}-1$ and the base lies within Subchron C5CR-3.

Discussion. This zone correlates to the lower portion of the $D$. maccollumii Zone of Gersonde and Burckle (1990) because of our redefinition of the upper boundary.

\section{Crucidenticula kanayae Partial Range Zone}

Authors. Harwood and Maruyama (this paper).

Top. FO of Denticulopsis maccollumii.

Base. FO of Crucidenticula kanayae. Ma.

Stratigraphic position and age. upper lower Miocene, 17.0-18.0

Paleomagnetic correlation. This zone ranges from the middle of Subchron C5CR-3 down to the middle of Subchron C5D.

Discussion. We replace the Crucidenticula nicobarica Zone used in the zonal scheme of Baldauf and Barron (1991) with this zone because C. nicobarica was rare and occurred discontinuously in Leg 120 holes. The lower range of both $C$. kanayae and $C$. nicobarica is similar, so that these two zones span nearly the same stratigraphic interval. It is possible that the $C$. kanayae we identify is the same as $C$. nicobarica identified in Baldauf and Barron (1991) and other works.

\section{Thalassiosira fraga Partial Range Zone}

Authors. Barron and Baldauf (1991), modified herein.

Top. FO of Crucidenticula kanayae.

Base. FO of Thalassiosira fraga.

Stratigraphic position and age. upper lower Miocene, 18.0-21.2 (21.5) Ma. The base of this zone is probably older than indicated here and could be as old as $21.7 \mathrm{Ma}$ (Abelmann, this volume; Harwood et al., this volume).

Paleomagnetic correlation. This zone ranges from Subchron C5D down to the lower portion of Subchron C6A.

Subzones: This zone is divided into three subzones. The upper Subzones "c" and " $b$ " are divided by the LO of $T$. fraga, with a mutual boundary at $\sim 18.6 \mathrm{Ma}$ within Subchron C5EN. The boundary between the lower two subzones, " $b$ " and " $a$ ", is defined by the LO of Rossiella symmetrica at $\sim 19.7 \mathrm{Ma}$ within Subchron C6N.

Remarks. This zone is distinct from the T. fraga Zone of Schrader and Fenner (1976) from the Norwegian Sea and the North Pacific of Barron (1985). We use the FO of $C$. kanayae rather than the FO of $C$. nicobarica (see above).

\section{Thalassiosira spumellaroides Partial Range Zone}

Authors. Schrader (1976), redefined in Baldauf and Barron (1991).

Top. FO of Thalassiosira fraga.

Base. FO of Thalassiosira spumellaroides.

Stratigraphic position and age. lower lower Miocene, 21.2 (21.5)22.6 Ma.

Paleomagnetic correlation. This zone ranges from Subchron C6A down to a level near the boundary between Subchrons C6AAR-2 and C6BN.
Subzones. This zone is divided into two subzones by the LO of Azpeitia gombosi, with the boundary between Subzones " $\mathrm{a}$ " and " $\mathrm{b}$ " at $\sim 21.5$ Ma within Subchron C6AN-2.

Rocella gelida Partial Range Zone

Authors. Bukry and Foster (1974), modified by Baldauf and Barron (1991)

Top. FO of Thalassiosira spumellaroides.

Base. FO of Rocella gelida.

Stratigraphic position and age. lowermost lower Miocene to middle upper Oligocene, 22.6-27.5 Ma; Baldauf and Barron (1991) report an age of $26.2 \mathrm{Ma}$ for the FO of $R$. gelida.

Paleomagnetic correlation. This long zone ranges from near the boundary between Subchrons C6AAR-2 and C6BN down to the middle of Subchron C8N.

Subzones. Three subzones are proposed within the $R$. gelida Zone. The boundary between the younger two Subzones "c" and " $b$ " is drawn at the LO of Lisitzinia ornata, which is dated at $24.5 \mathrm{Ma}$ within the upper portion of Subchron C6CR-3. The boundary between Subzones "b" and "c" is drawn at the last common occurrence of Rocella vigilans var. B, which is dated at $26.3 \mathrm{Ma}$ within Subchron $C 7 R-2$. The boundary between the lower two zones is also approximated by the last consistent occurrence of Hemiaulus incisus.

\section{Lisitzinia ornata Partial Range Zone}

Author. Harwood (1986b).

Top. FO of Rocella gelida.

Base. FO of Lisitzinia ornata.

Stratigraphic position and age. middle to lower upper Oligocene, 27.5-29.2 Ma.

Paleomagnetic correlation. This zone ranges from the middle of Subchron C8N down to the base, or just below, Subchron C9N-2.

\section{Azpeitia gombosi Partial Range Zone}

Authors. Harwood and Maruyama (this paper).

Top. FO of Lisitzinia ornata.

Base. FO of Azpeitia gombosi.

Stratigraphic position and age. lowermost upper Oligocene, 29.2$29.8 \mathrm{Ma}$.

Paleomagnetic correlation. This short zone ranges from the base, or just below, Subchron C9N-2 down to within Subchron C10N-1.

\section{Rocella vigilans Partial Range Zone}

Authors. Jousé (1974), redefined herein.

Top. FO of Azpeitia gombosi.

Base. FO of Rocella vigilans var. A.

Stratigraphic position and age. lowermost upper Oligocene to middle lower Oligocene, 29.8-32.2 Ma

Paleomagnetic correlation. This zone ranges from Subchron C10N-1 down to Subchron C11R-2.

Subzones. This zone is divided into two subzones based on the highest occurrence of the small form of Rocella vigilans var. A (small), at a level approximating the upper/lower Oligocene boundary. This secondary datum may have only local significance, in areas to the south, where the range of $R$. vigilans is perhaps continuous and not interrupted.

Discussion. A stratigraphic gap in the occurrence of Rocella vigilans is noted on Leg 120 sediments between 30.6 and $29.3 \mathrm{Ma}$ in Holes 747A, 748B, and 749B. Small forms of $R$. vigilans (var. A) characterize the interval below this gap, and much larger forms (var. B) characterize the interval above the gap (Plate 4). Scanning electron microscope analysis is needed to determine if both forms are conspecific. Caution should be taken in determining the base of this zone to avoid incorrectly using the base of the younger and larger var. B, rather than the older and smaller var. A. The $\mathrm{FO}$ of $R$. vigilans var. A occurs within the A. gombosi Zone.

\section{Synedra jouseana Partial Range Zone}

Author. Harwood (1986b), redefined herein.

Top. FO of Rocella vigilans var. A.

Base. FO of Synedra jouseana. $\mathrm{Ma}$.

Stratigraphic position and age. middle lower Oligocene, 32.2-32.6

Paleomagnetic correlation. This short zone ranges between Subchrons $\mathrm{C} 11 \mathrm{R}-2$ and $\mathrm{C} 12 \mathrm{~N}$. 
Discussion. This zone is equivalent to Subzone " $\mathrm{a}$ " of the Synedra jouseana Zone of Harwood (1986B), a portion of Subzone " $b$ " of the Rhizosolenia gravida Zone of Baldauf and Barron (1991), a portion of the Rhizosolenia antarctica Zone of Fenner (1984a, 1984b), and the $K$. minor and Pyxilla reticulata zones and a portion of the C. superbus Zone of Gombos and Ciesielski (1983).

\section{Rhizosolenia oligocaenica Partial Range Zone}

Authors. Gombos and Ciesielski (1983), renamed in Harwood et al. (1989a) and redefined herein.

Top. FO of Synedra jouseana.

Base. FO of Rhizosolenia oligocaenica.

Stratigraphic position and age. middle to lower lower Oligocene, 32.6-35.5 Ma; Baldauf and Barron (1991) report an age between 34 and 34.2 for the base of this zone.

Paleomagnetic correlation. This zone ranges from Chron $\mathrm{C} 12 \mathrm{~N}$ down to Chron $\mathrm{C} 13 \mathrm{~N}$.

Subzones. Three subzones divide the Rocella oligocaenica Zone. The boundary between the upper two subzones "c" and " $b$ " is defined by the LO of Rhizosolenia oligocaenica at $\sim 33$ Ma near the top of Subchron C12R-1. The boundary between Subzones "b" and " $\mathrm{a}$ " is defined by the LO of Triceratium polymorphus (T. macroporum of Gombos and Ciesielski, 1983; Baldauf and Barron, in press) at $34.5 \mathrm{Ma}$

Discussion. Harwood et al. (1989a) renamed the $R$. gravida Zone of Gombos and Ciesielski (1983) the $R$. oligocaenica Zone, following the taxonomic consideration of Fenner (1985) that $R$. gravida is conspecific with $R$. oligocaenica. Schrader and Fenner (1976) have priority in naming this taxon, suggesting that $R$. gravida of Gombos and Ciesielski (1983) is a junior synonym.

\section{DIATOM BIOSTRATIGRAPHY AT LEG 120 SITES}

\section{Site 747}

\section{General}

Site 747 was drilled on a broad terrace located in the transition zone between the Northern and Southern Kerguelen plateaus, approximately $500 \mathrm{~km}$ south of the Polar Front ( $54^{\circ} 49^{\prime} \mathrm{S}$ and $76^{\circ} 48^{\prime} \mathrm{E}$ longitude; water depth, $1697.7 \mathrm{~m}$ ). A pelagic sedimentary section spanning the lower Santonian through upper Pleistocene ( $296.5 \mathrm{~m}$ thick) and underlying basalt $(53.9 \mathrm{~m})$ was recovered in three holes drilled at Site 747 . Objectives of this site were (1) to determine the nature and age of basement at this northern site for comparison with other sites on the Southern Kerguelen Plateau; and (2) to study the paleoceanographic history of the region and trace migrations of the Polar Front through time.

The sedimentary section recovered at Site 747 includes approximately $33 \mathrm{~m}$ of upper Pleistocene to upper Miocene foraminifer diatom ooze (Unit I). Ice-rafted debris and dropstones are prevalent only in the upper $20 \mathrm{~m}$. This overlies Miocene to lower Paleocene nannofossil ooze and chalk that continues down to $181.45 \mathrm{~m}$ below seafloor (mbsf). Lower Danian to Santonian sediments (Units II-IV) continue from this level down to $296.5 \mathrm{~m}$ and are underlain by basalt flows to 350.5 . Sedimentation rates are slow from the Oligocene to Holocene of $\sim 5 \mathrm{~m} / \mathrm{m}$.y and at least 10 hiatuses are identified from diatom biostratigraphy and magnetostratigraphy within the upper Oligocene to Pleistocene section in Hole 747A (Harwood et al., this volume). None of these represent more than 1-2 m.y. of time.

\section{Diatom Biostratigraphy}

Diatoms are present in all sediments from Cores 120$747 \mathrm{~A}-1 \mathrm{H}$ to $-17 \mathrm{H}$. Abundance, diversity, and dominance of diatom species is variable throughout this sequence, reflecting changes in oceanic regime of fertility and temperature. Specific aspects of this variability are not treated in this paper, which focuses largely on the diatom biostratigraphic record.
Poor preservation of siliceous microfossils in the lower Miocene and lower middle Miocene interval limits the reliability of diatom ages at this site.

At the time of this writing, data from Hole 747A are more complete than at Hole 747B, because of sparse sampling at the latter hole. Diatom biostratigraphic distribution tables and biostratigraphic zonations are presented for the upper upper Miocene-Pleistocene of Hole 747A in Table 4 and Figure 6 (in back pocket) and Hole 747B in Table 5 and Figure 7 (in back pocket); for the remaining Miocene of Hole 747A in Table 6 and Figure 8 (in back pocket); and for the Oligocene of Hole $747 \mathrm{~A}$ in Table 7 and Figure 9 (in back pocket). Additional biostratigraphic information and justification for stated ages and the presence of hiatuses can be better evaluated in Harwood et al. (this volume).

An apparently complete Pleistocene to uppermost Pliocene section was recovered at both holes, including the Thalassiosira lentiginosa through $T$. kolbei zones. A hiatus represents most of the upper Pliocene in Hole 747A, but the section appears to be more complete in Hole $747 \mathrm{~B}$, where only a portion of the $T$. kolbei and T. vulnifica zones is missing. A hiatus representing much of the lower Pliocene Nitzschia barronii through $N$. reinholdii zones spans across the Miocene/Pliocene boundary at Site 747 and all other Leg 120 sites. A several-meter-thick package of upper Miocene sediment is represented by the $N$. reinholdii Zone and upper $H$. ovalis Zone, found only in Hole 747B. Another regional hiatus below these zones removed much of the upper upper Miocene. Portions of all of the upper Miocene diatom zones between 7 and $12 \mathrm{Ma}$ are represented in Hole 747A. The Denticulopsis praedimorpha Zone is missing in hiatus at Hole $747 \mathrm{~A}$, as indicated by the co-occurrence of the FOs of $D$. dimorpha and $D$. praedimorpha in the same interval between 66.0 and 66.47 mbsf. This hiatus also removed the upper portion of the middle Miocene $N$. denticuloides Zone, below which an interval representing $\sim 2 \mathrm{~m}$.y. continues down to the middle of the $N$. grossepunctata Zone, where another hiatus is noted by the joint lowest occurrence of $N$. grossepunctata and $A$. ingens. This coincidence indicates the absence of the $A$. ingens $-D$. maccollumii Zone in Hole $747 \mathrm{~A}$.

\section{Site 748}

\section{General}

Site 748 is located in the western part of the Raggatt Basin on the Southern Kerguelen Plateau $\left(58^{\circ} 27^{\prime} \mathrm{S}\right.$ and $78^{\circ} 59^{\prime} \mathrm{E}$; water depth, $1290 \mathrm{~m}$ ), approximately $900 \mathrm{~km}$ south of the present Polar Front. Objectives at this site included the recovery of an expanded section of Paleogene and Cretaceous sediments and basement that could be used to decipher the tectonic, geologic, and paleoceanographic history of the Southern Kerguelen Plateau. Two holes were drilled at this site to a total penetration depth of $935 \mathrm{~m}$; this study focuses on Hole 748B. Approximately $15 \mathrm{~m}$ of Pliocene-Pleistocene diatom ooze with radiolarian- and foraminifer-enriched intervals (Unit I) overlie upper Miocene to upper Paleocene nannofossil ooze, chalk, and chert (Unit II) that continues to 397.4 mbsf. Upper Cretaceous glauconitic sediments (Unit III) continue down to 898.8 mbsf where basalt was cored to 935 mbsf. Diatoms are abundant to common throughout the upper $115 \mathrm{~m}$ in Hole 748B (lower Oligocene); they are generally poorly preserved with sporadic occurrence below this, in the middle to upper Eocene (115-180 mbsf). Core recovery of $100 \%$ through this interval provides an excellent biosiliceous and calcareous biostratigraphic reference section for the southern high latitudes that is calibrated with relatively good paleomagnetic control. However, numerous hiatuses are identified in 
the Neogene and Upper Paleogene, some of which represent as much as $4 \mathrm{~m} . \mathrm{y}$. of missing sediment.

\section{Diatom Biostratigraphy}

Details of the biostratigraphic zonal determinations can be found in the accompanying figures. Diatom distribution tables and biostratigraphic zonation are presented for the upper upper Miocene-Pleistocene in Table 8 and Figure 10 (in back pocket); for the remaining Miocene of Hole 748B in Table 9 and Figure 11 (in back pocket); and for the Oligocene to middle Eocene in Table 10 and Figure 12 (in back pocket).

The uppermost Pleistocene is missing in Hole 748B, as indicated by the occurrence of A. ingens at the top of the stratigraphic section. A $\sim 1.5-\mathrm{m} . y$.-long hiatus spans the Pleistocene/Pliocene boundary. Below the hiatus, the joint highest occurrence of diatoms $T$. kolbei, $T$. vulnifica, and $T$. insigna marks a position within the $T$. insigna-T. vulnifica Zone. A long time interval is represented in a hiatus $(\sim 10 \mathrm{mbsf})$ from the lower Pliocene at $\sim 4.0 \mathrm{Ma}$ down to $\sim 8.1 \mathrm{Ma}$. A package of upper Miocene to uppermost middle Miocene sediment continues below this hiatus down to the middle of the $D$. praedimorpha $-N$. denticuloides Zone, with a short sedimentation break indicated between the A. kennettii and D. hustedtii Zones. Much of the middle Miocene to uppermost lower Miocene is missing in Hole 748B, except for a short interval bearing the $N$. grossepunctata Zone between $\sim 38$ and 40 mbsf. Seven additional hiatuses are evident in the remaining lower Miocene to Oligocene section.

\section{Site 749}

\section{General}

Site 749 is located on the western flank of the Banzare Bank on the Southern Kerguelen Plateau $\left(58^{\circ} 43^{\prime} \mathrm{S}\right.$ and $76^{\circ} 25^{\prime} \mathrm{E}$; water depth, $1069.5 \mathrm{~m}$ ). The objective of this site was to recover a thick section of basement rocks from the Southern Kerguelen Plateau. Approximately $200 \mathrm{~m}$ of upper Oligocene to lower Eocene nannofossil ooze with chert, chalk, and porcellanite was drilled, with $100 \%$ recovery of the upper $43.8 \mathrm{mbsf}$ and considerably lower recovery rates below this level as a result of the presence of Eocene cherts. Basement was reached at $202.0 \mathrm{mbsf}$ and $23.1 \mathrm{~m}$ of basalt was recovered to a depth of $249.5 \mathrm{mbsf}$. A thin layer of mixed upper Pliocene and lower Pleistocene diatom ooze with foraminifers and ice-rafted debris (Unit I) lies unconformably on the Paleogene nannofossil ooze (Unit II) in Holes 749A and 749B.

\section{Diatom Biostratigraphy}

Details of the biostratigraphic zonal determinations can be found in the accompanying figures. Additional stratigraphic information of the diatom datums, hiatus levels, and the magnetostratigraphic record of Heider et al. (this volume) for Hole 749B is presented in Harwood et al. (this volume). Diatom relative abundance and biostratigraphic distribution tables are presented for the thin, dissected Pliocene to Pleistocene sediments in Table 11 (in back pocket), and the data for the middle Eocene to middle upper Oligocene sediments are presented in Table 12 and Figure 13 (in back pocket).

Two packages of Pliocene-Pleistocene sediment were identified between gravel-lag layers, indicating the repeated deposition and subsequent winnowing of biogenic sediments (see Schlich, Wise, et al., 1988, "Site 749"' chapter, for photographs and further discussion). Two intervals representing a portion of the upper Pleistocene $A$. ingens Zone and the mid-Pliocene $T$. insigna-T. vulnifica Zone are identified between the gravel lags. Previous episodes of biogenic deposition are indicated by diatoms in sediment-filled burrows in the underlying Oligocene nannofossil ooze. Marine benthos apparently burrowed upper Miocene sediments into the underlying Oligocene sediments. The Miocene section was then eroded away, leaving the burrows as the only remnant of this depositional event. An early Pliocene depositional event is also indicated by the diatom flora in other burrows (Table 11, back pocket).

A good lower Oligocene to middle upper Oligocene section underlies the thin Neogene cover. The absence of $R$. gelida indicates a level within the $L$. ornata Zone at the top of the section (Table 12, back pocket). The stratigraphic range of Rocella vigilans is apparently interrupted on the Kerguelen Plateau. Two varieties (small and large in Plate 4) are recorded with distinct stratigraphic ranges. A gap exists between the highest occurrence of the smaller form and the lowest occurrence of the larger (younger) form. This gap may represent the retreat of Rocella vigilans south of the Kerguelen Plateau, followed by its reappearance as a larger form as a result of normal evolutionary drift (Gombos and Ciesielski, 1983; note that $R$. vigilans tends toward larger forms through time). Continuous recovery (Fig. 2) and good magnetostratigraphic signatures enable good age determination for this poorly dated time interval.

\section{Site 751}

\section{General}

Site 751 is located in the central part of the Raggatt Basin on the Southern Kerguelen Plateau ( $57^{\circ} 44^{\prime} \mathrm{S}$, $79^{\circ} 48^{\prime} \mathrm{E}$; water depth, $1633.8 \mathrm{~m}$ ). The objective of drilling Site 751 was to recover a high-resolution Neogene and Paleogene stratigraphic section that was deposited above the carbonate compensation depth (CCD), but south of the Polar Front. A single hole drilled with the APC recovered a 166.2-m section of the upper Pleistocene through the middle lower Miocene mixed biosiliceous and calcareous ooze. Upper Pleistocene to lower Pliocene sediments of Unit I (0-40.1 mbsf) are diatom ooze with minor ice-rafted debris, foraminifers, volcanic ash, and porcellanite. Lower Pliocene to middle lower Miocene sediments of Unit II (40.1-166.2 mbsf) are diatom nannofossil ooze, with diatoms and nannofossils alternating as the dominant constituent.

\section{Diatom Biostratigraphy}

Details of the biostratigraphic zonal determinations can be found in the accompanying figures. Additional stratigraphic information and position of diatom zones, revised ages for diatom datums, hiatus levels, and the magnetostratigraphic record of Heider et al. (this volume) for Hole 751A is presented in Harwood et al. (this volume). Diatom distribution tables and biostratigraphic zonation are presented for the upper Miocene to Pleistocene sediments in Table 13 and Figure 14 (in back pocket); and the data for the middle lower Miocene to middle upper Miocene sediments are presented in Table 14 and Figure 15 (in back pocket). The Pleistocene and late Pliocene section is interrupted by several hiatuses. Other breaks in sedimentation are noted at the Pliocene/Miocene boundary, within the late Miocene, within the middle Miocene, and a possible hiatus across the early/middle Miocene boundary (Harwood et al., this volume).

\section{BIOSTRATIGRAPHIC DISCUSSION}

Leg 120 represents the last of a series of four cruises of the JOIDES Resolution to the southern high latitudes (Barker, Kennett, et al., 1988; Ciesielski, Kristoffersen, et al., 1988; Barron, Larsen, et al., 1989; Schlich, Wise, et al., 1989). The Oligocene to Holocene diatom biostratigraphic scheme pre- 
sented in this paper reflects the advances made during each of these legs. Gersonde (Leg 113) and Baldauf and Barron (Leg 119) provided advance copies of their results from Leg 113 and 119 studies. Information from these stratigraphic studies are one reason for the confidence in the higher resolution zonation proposed herein (Figs. 3 and 16 and Tables 15-17). Our compilation drew upon these and existing diatom studies for information on stratigraphic intervals missing or poorly represented in Leg 120 sections. Many problems still remain with interpretations of all of the 113,114, 119 and 120 diatom records that can be more easily addressed now that all of the data are studied and reported in these initial surveys. Constraints for rapid publication in the Proceedings of the Ocean Drilling Program do not provide enough time for thorough study and data assimilation. Future studies of existing sediment materials within the proposed stratigraphic framework as well as tracing the ranges of the newly proposed diatom taxa will undoubtedly improve the dating potential of poorly known biostratigraphic events, and age disparity and potential diachroneity issues can be adequately addressed. Magnetostratigraphic calibration (Heider et al., this volume; Inokuchi and Heider, this volume) afforded by APC recovery at the various Leg 120 sites enabled more direct comparison of individual biostratigraphic events among these sites, and the relatively precise determination of hiatus duration and ages of sedimentary packages (Fig. 16). The biostratigraphic synthesis of Harwood et al. (this volume) should be heavily consulted when reading this paper for further reference to correlations between magnetostratigraphic events, diatom events, and stratigraphic events of other microfossil groups. The ages of many diatom datums are adjusted in Harwood et al. (this volume) from information gained through the age-depth plot procedure, by shifting the datum in time to fall on the line of correlation. No such compilation was done for this paper, although an attempt was made in the last several tables of this paper. Tables $15-17$ present ages for these diatom events determined at each site.

Cenozoic sediments recovered on the Kerguelen Plateau provide a critical link between the Antarctic region and the lower latitudes. This is particularly apparent because of our ability to correlate Oligocene to Holocene calcareous and siliceous microfossil zonations. Thus, the sections reported here for Leg 120 and in Baldauf and Barron (1991) for Leg 119 will serve as the principal basis for future biostratigraphic reference, as a first step. Consideration of the biostratigraphic record from other areas of the Southern Ocean and the Antarctic continent will eventually result in a zonation that should have both broad geographic application and high age resolution.

The diatom zonation presented here outlines the current status of Oligocene to Holocene diatom biostratigraphy in the Southern Ocean and Antarctic area. It builds on three previous ODP legs to the southern high latitudes and over $20 \mathrm{yr}$ of data collection in this region. We propose 45 diatom zones and subzones in this paper, and considerably more individual datums are dated through magnetostratigraphic extrapolation (Tables 15-17). Although we are still some distance from realizing the full potential of diatoms to subdivide Southern Ocean sediments, this contribution will aid future attempts toward biostratigraphic refinement. The continuing documentation of new species in the Southern Ocean, many of which have useful short stratigraphic ranges, illustrates that greater stratigraphic resolution is still possible. Several of the zones proposed herein are based on sequences from other studies. Perhaps this compilation is premature and the zones would be better defined in sections where particular intervals were more complete. Our goal here, however, was to help get the process started. In future work, these reference sections need to be selected carefully from all of the available sites and with agreement from the Southern Ocean diatom community. Preference should be given to those sections that show (1) continuous deposition, (2) good magnetic stratigraphy, (3) mixed calcareous and siliceous microfossils, and (4) good preservation. All sites will need to be compared by means of graphic-correlation techniques to determine which datums are reliable around the Southern Ocean and to identify the most complete sections. The Kerguelen Plateau-Prydz Bay transect of holes (Fig. 1) drilled during Legs 119 and 120 provides an excellent suite of holes to begin this comparison.

\section{ACKNOWLEDGMENTS}

We acknowledge the dedicated technical assistance of $R$. Jacko, M. Izold, R. Graham, M. Karrer, and P. Resiwati in sample preparation and photography. The paper benefited from constructive reviews and comments by J. Barron, J. Baldauf, J. Fenner, and R. Gersonde. We thank R. Gersonde, J. Barron, and J. Baldauf for kindly providing preprints of their Southern Ocean ODP contributions. This research was supported by a USSAC grant and NSF grant DPP-876411 to D. M. Harwood. This is Byrd Polar Research Center Contribution No. 705 .

\section{REFERENCES}

Abbott, W. H., 1974. Temporal and spatial distribution of Pleistocene diatoms from the southeast Indian Ocean. Nova Hedwigia Beih., 25:291-347.

Akiba, F., 1982. Late Quaternary diatom biostratigraphy of the Bellingshausen Sea, Antarctic Ocean. Rep. Tech. Res. Cen. JNOC, 16:31-74.

1986. Middle Miocene to Quaternary diatom biostratigraphy in the Nankai Trough and Japan Trench, and modified lower Miocene through Quaternary diatom zones for middle-to-high latitudes of the North Pacific. In Kagami, H., Karig, D. E., Coulbourn, W. T., et al., Init. Repts. DSDP, 87: Washington (U.S. Govt. Printing Office), 393-481.

Akiba, F., and Yanagisawa, Y., 1986. Taxonomy, morphology and phylogeny of the Neogene diatom zonal marker species in the middle-to-high latitudes of the North Pacific. In Kagami, H., Karig, D. E., Coulbourn, W. T., et al., Init. Repts. DSDP, 87: Washington (U.S. Govt. Printing Office), 483-554.

Akiba, F., Yanagisawa, Y., and Ishi, T., 1982. Neogene diatom biostratigraphy of the Matsushima Area and its environs. Miyagi Prefecture, Northeast Japan. Bull. Geol. Soc. Jpn., 33:215-239. (Japanese with English abstract)

Andrews, G., 1973. Systematic position and stratigraphic significance of the marine diatom Raphidodiscus marylandicus Christian. Nova Hedwigia Beih., 45:231-250.

1980. Neogene diatoms from Petersburg, Virginia. Micropaleontology, 26:17-48.

Anissimova, N., 1937. Diatomovye Nizhnego Paleogena: Leningrad (Srednee Povolzhe)

Bailey, J. W., 1856. Notice of microscopic forms in the soundings of the Sea of Kamtschatka. Am. J. Sci., 22:1-6.

Baldauf, J. G., and Barron, J. A., 1980. Actinocyclus ingens var. nodus, a new stratigraphically useful diatom of the circum-North Pacific. Micropaleontology, 26:103-110.

1982. Diatom biostratigraphy and paleoecology of the type section of the Luisian Stage, central California. Micropaleontology, 28:59-84.

1991. Diatom biostratigraphy: Kerguelen Plateau and Prydz Bay regions of the Southern Ocean. In Barron, J., Larsen, B., et al., Proc. ODP, Sci. Results, 119: College Station, TX (Ocean Drilling Program), 547-598.

Baldauf, J. G., and Monjanel, A.-L., 1989. An Oligocene diatom biostratigraphy for the Labrador Sea: DSDP Site 112 and ODP Hole 647A. In Srivastava, S. P., Arthur, M., Clement, B., et al., Proc. ODP, Sci. Results, 105: College Station, TX (Ocean Drilling Program), 323-347. 
Barker, P. F., Kennett, J. P., et al., 1988. Proc. ODP, Init. Repts., 113: College Station, TX (Ocean Drilling Program).

Barron, J., Larsen, B., et al., 1989. Proc. ODP, Init. Repts., 119: College Station, TX (Ocean Drilling Program).

Barron, J. A., 1976. Revised Miocene and Pliocene diatom biostratigraphy of Upper Newport Bay, Newport Beach, California. Mar. Micropaleontol., 1:27-63.

1980. Lower Miocene to Quaternary diatom biostratigraphy of Leg 57, off northeastern Japan, Deep Sea Drilling Project. In von Huene, R., Nasu, N., et al., Init. Repts. DSDP, 56, 57 (Pt.2): Washington (U.S. Govt. Printing Office), 641-685.

1981. Late Cenozoic diatom biostratigraphy and paleoceanography of the middle-latitude eastern North Pacific, Deep Sea Drilling Project Leg 63. In Yeats, R. S., Haq, B. U., et al., Init. Repts. DSDP, 63: Washington (U.S. Govt. Printing Office), 507535 .

1983. Latest Oligocene through early middle Miocene diatom biostratigraphy of the eastern tropical Pacific. Mar. Micropaleontol., 7:487-515.

1985a. Late Eocene to Holocene diatom biostratigraphy of the equatorial Pacific Ocean, Deep Sea Drilling Project Leg 85. In Mayer, L., Theyer, F., Thomas, E., et al., Init. Repts. DSDP, 85: Washington (U.S. Govt. Printing Office), 413-456.

$1985 \mathrm{~b}$. Miocene to Holocene planktic diatom stratigraphy. In Bolli, H. M., Saunders, J. B., and Perch-Nielsen, K. (Eds.), Plankton Stratigraphy: Cambridge (Cambridge Univ. Press), 763809.

, in press. Neogene diatom datum levels in the equatorial and North Pacific. In Saito, T., and Ishizaki, K. (Eds.), The Centenary of Japanese Micropaleontology: Tokyo (Univ. Tokyo Press).

Barron, J. A., and Baldauf, J. G., 1986. Diatom stratigraphy of the lower Pliocene part of the Sisquoc Formation, Harris Grade Section, California. Micropaleontology, 32:357-371.

Barron, J. A., Baldauf, J. G., Barrera, E., Caulet, J.-P., Huber, B. T., Keating, B. H., Lazarus, D., Sakai, H., Thierstein, H., and Wei, W., 1991. Biochronologic and magnetochronologic synthesis of Leg 119 sediments from the Kerguelen Plateau and Prydz Bay, Antarctica. In Barron, J., Larsen, B., et al., Proc. ODP, Sci. Results, 119: College Station, TX (Ocean Drilling Program), 813-848.

Barron, J. A., Bukry, D., and Poore, R. Z., 1984. Correlation of the middle Eocene Kellogg Shale of northern California. Micropaleontology, 30:138-170.

Barron, J. A., and Burckle, L. H., 1987. Diatoms from 1984 U.S.G.S. Antarctic Cruise in the Ross Sea. In Cooper, A. K., and Davey, F. J. (Eds.), The Antarctic Continental Margin: Geology and Geophysics of the Western Ross Sea. Circum-Pacific Counc. Energy Min. Resours., Earth Sci. Ser., 5B:225-230.

Berggren, W. A., Kent, D. V., Flynn, J. J., and Van Couvering, J. A., 1985a. Cenozoic geochronology. Geol. Soc. Am. Bull., 96:14071418.

Berggren, W. A., Kent, D. V., and Van Couvering, J. A., 1985b. The Neogene: Part 2. Neogene geochronology and chronostratigraphy. In Snelling, N. J. (Ed.), The Chronology of the Geological Record. Geol. Soc. London Mem., 10:211-260.

Brady, H. T., 1977. Thalassiosira torokina n. sp. (diatom) and its significance in Late Cenozoic biostratigraphy. Antarct. J. U.S., 12:122-123.

1979. The extraction and interpretation of diatom zones in Dry Valley Drilling Project Holes 10 and 11, Taylor Valley, South Victoria Land, Antarctica. Mem. Nat. Inst. Polar Res., 13:150163.

1983. Interpretation of sediment cores from the Ross Ice Shelf Site J-9, Antarctica. Nature, 303:510-512.

Brady, H. T., and Martin, H., 1979. Ross Sea region in the middle Miocene: a glimpse of the past. Science, 203:437-438.

Brightwell, T., 1858. Remarks on the genus "Rhizosolenia" of Ehrenberg. Q. J. Microsc. Sci., 6:93.

1859. On some of the rare undescribed species of Diatomaceae. Part 1. Q. J. Microsc. Sci., 7:179-181.

Brown, N. E., 1920. Some new and old antarctic diatoms. English Mechanic., 111:210-233.

Brun, J., and Tempère, J., 1889. Diatomées fossiles du Japan. Especes Marines et Nouvelles des Calcaire Argileux de Sendai et de Yedo. Société de Physique et d'Historie Naturelle de Genève, Mémoires, Genève, 30:1-75.

Bukry, D., 1978. Cenozoic silicoflagellate and coccolith stratigraphy, northwestern Atlantic Ocean, Deep Sea Drilling Project Leg 43. In Benson, W. E., Sheridan, R. E., et al., Init. Repts. DSDP, 44: Washington (U.S. Govt. Printing Office), 775-805.

Bukry, D., and Foster, J. H., 1974. Silicoflagellate zonation of Upper Cretaceous to lower Miocene deep sea sediments. J. Res. U.S. Geol. Surv., 2:303-310.

Burckle, L. H., 1972. Late Cenozoic planktonic diatom zones from the eastern equatorial Pacific. Nova Hedwigia Beih., 39:217-246.

1984. Ecology and paleoecology of the marine diatom Eucampia antarctica (Castracane) Manguine. Mar. Micropaleontol., 9:77-86.

Burckle, L. H., and Abrams, N., 1987. Regional late Pliocene-early Pleistocene hiatuses of the Southern Ocean-diatom evidence. Mar. Geol., 77:207-218.

Castracane, D. A., 1886. Report on the Diatomaceae collected by HMS “Challenger" during the years 1873-1876. Rep. Sci. Results, H.M.S. Challenger, Botany, 2:1-178.

Christian, T., 1887. New diatomaceous deposits. Am. Month. Micro. J., "The Microscope," 7:65-68.

Ciesielski, P.F., 1983. The Neogene and Quaternary diatom biostratigraphy of subantarctic sediments, Deep Sea Drilling project Leg 71. In Ludwig, W. J., Krasheninnikov, V. A., et al., Init. Repts. DSDP, 71 (Pt. 2): Washington (U.S. Govt. Printing Office), 635-665.

1986. Middle Miocene to Quaternary diatom biostratigraphy of Deep Sea Drilling Project Site 594, Chatham Rise, southwest Pacific. In Kennett, J. P., von der Borch, C. C., et al., Init. Repts. DSDP, 90: Washington (U.S. Govt. Printing Office), 863885.

Ciesielski, P. F., Kristoffersen, Y., et al., 1988. Proc. ODP, Init. Repts., 114: College Station, TX (Ocean Drilling Program).

Ciesielski, P. F., Ledbetter, M. T., and Ellwood, B. B., 1982. The development of Antarctic glaciation and the Neogene paleoenvironment of the Maurice Ewing Bank. Mar. Geol., 46:1-51.

Ciesielski, P. F., and Wise, S. W., Jr., 1977. Geologic history of the Maurice Ewing Bank of the Falkland Plateau (southwest Atlantic sector of the Southern Ocean) based on piston and drill cores. Mar. Geol., 25:175-207.

Cleve, P. T., and Grunow, A., 1880. Beiträge zur kenntnis der artischen Diatomeen. K. Sven. Vetenskapsakad. Handl., 17:1121.

Cleve-Euler, A., 1941. Alttertiäre Diatomeen und Silicoflagellaten in Inneren schwedens, gefunden und gezeichtnet von Åke Berg, beschrieben von Asterid Cleve-Euler. Palaeontographica, 92:165-212.

DeFelice, D. R., 1979. Morphological comparison of Coscinodiscus lentiginosus Janisch and Coscinodiscus obovatus Castracane. Antarct. J. U.S., 14:127-129.

DeFelice, D. R., and Wise, S. W., Jr., 1981. Surface lithologies, biofacies, and diatom diversity patterns as models for delineation of climate change in the southwest Atlantic Ocean. Mar. Micropaleontol., 6:29-70.

Desikachary, T. V., Gowthaman, S., and Latha, Y., 1987. Diatom flora of some sediments from the Indian Ocean region. In Desikachary, T. V. (Ed.), Atlas of Diatoms (Vol. 2): Madras (Madras Science Foundation), PI. 4.

Donahue, J. G., 1967. Diatoms as indicators of Pleistocene climatic fluctuations in the Pacific sector of the Southern Ocean. Progress in Oceanography (Vol. 4): New York (Pergamon Press), 133-141. 1970. Pleistocene diatoms as climatic indicators in North Pacific sediments. Mem. Geol. Soc. Am., 126:121-138.

Ehrenberg, C. G., 1844. Mittheilung über zwei neue Lager von Gebirgsmassen aus Infusonien als Meeres-Absatz in NordAmerika und eine Vergleichung derselben mit den organischen Kreide-Gebilden in Europa und Afrika. K. Akad. Wiss. Berlin Abh., 1844, 57-97.

1854. Mikrogeologie; Das Erden und Felsen Schaffende Wirken des Unsichtbar Kleines Selbständigen Lebens auf der Erde. Leipzig (Leopold Voss).

Fenner, J., 1978. Cenozoic diatom biostratigraphy of the equatorial and southern Atlantic Ocean. In Supko, P. R., Perch-Nielsen, K., 
et al., Init. Repts. DSDP, 39 (Suppl.): Washington (U.S. Govt. Printing Office), 491-623.

1984a. Eocene-Oligocene planktic diatom stratigraphy in the low latitudes and the high southern latitudes. Micropaleontology, 30:319-342.

1984b. Middle Eocene to Oligocene planktonic diatom stratigraphy from Deep Sea Drilling sites in the south Atlantic, equatorial Pacific, and Indian oceans. In Hay, W. W., Sibuet, J.-C., et al., Init. Repts. DSDP, 75 (Pt. 2): Washington (U.S. Govt. Printing Office), 1245-1271.

1985. Late Cretaceous to Oligocene planktic diatoms. In Bolli, H. M., Saunders, J. B., and Perch-Nielsen, K. (Eds.), Plankton Stratigraphy: Cambridge (Cambridge Univ. Press), $713-$ 762.

1991. Late Pliocene-Quaternary quantitative diatom stratigraphy in the Atlantic sector of the Southern Ocean. In Ciesielski, P. F., Kristoffersen, Y., et al., Proc. ODP, Sci. Results, 114: College Station, TX (Ocean Drilling Program), 97-121.

Fenner, J., Schrader, H.-J., and Wienigk, H., 1976. Diatom phytoplankton studies in the southern Pacific Ocean, composition and correlation to the Antarctic Convergence and its paleoecological significance. In Hollister, C. D., Craddock, C., et al., Init. Repts. DSDP, 35: Washington (U.S. Govt. Printing Office), 757-813.

Forti, A., 1909. Studi per una monografia del genera Pyxilla (Diatomee) e dei generi affini. Nuova Notarisia, 20:5-24.

1912. Contribuzioni diatomologiche. XIII. Diagnoses diatomacearum quarumdam fossilium italicarum. Atti Reale Inst. Veneto di Sci., Lett. ed Arti, 72:1567-1700.

Frenguelli, J., 1960. Diatomeas y silicoflagelados recogidas en Tierra Adelia durande las Expediciones Polares Francesas de Paul-Emile Victor (1950-1952). Rev. Algologique, 5:3-48.

Fryxell, G. A., 1977. Thalassiosira australis Peragallo and T. lentiginosa (Janisch) G. Fryxell, comb. nov.: two Antarctic diatoms (Bacillariophyceae). Phycologia, 16:95-104.

Fryxell, G. A., and Hasle, G. R., 1972. Thalassiosira eccentrica (Ehrenberg) Cleve, T. symmetrica sp. nov., and some related Centric diatoms. J. Phycol., 8:297-317.

Fryxell, G. A., Sims, P. A., and Watkins, T. P., 1986. Azpeitia (Bacillariophyceae): related genera and promorphology. Sys. Bot. Monogr., 13:1-74.

Fryxell, G. R., Prasad, A.K.S.K., and Fryxell, P. A., 1989. Eucampia antarctica (Castracane) Mangin (Bacillariophyta): complex nomenclature and taxonomic history. Taxon, 38:638-640.

Gersonde, R., 1990. Taxonomy and morphostructure of Neogene diatoms from the Southern Ocean, ODP Leg 113. In Barker, P. F., Kennett, J. P., et al., Proc. ODP, Sci. Results, 113: College Station, TX (Ocean Drilling Program), 791-802.

in press. Taxonomy and morphostructure of Pliocene diatoms from the Maude Rise (Antarctic Ocean). Polarforschung.

Gersonde, R., and Burckle, L. H., 1990. Neogene diatom biostratigraphy of ODP Leg 113, Weddell Sea (Antarctic Ocean). In Barker, P. F., Kennett, J. P., et al., Proc. ODP, Sci. Results, 113: College Station, TX (Ocean Drilling Program), 761-789.

Gombos, A. M., Jr., 1974. New species of fossil diatom from the Antarctic. Antarct. J. U.S., 9:275.

1977. Paleogene and Neogene diatoms from the Falkland Plateau and Malvinas outer basin, Leg 36, Deep Sea Drilling Project. In Barker, P. F., Dalziel, I.W.D., et al., Init. Repts. DSDP, 36: Washington (U.S. Govt. Printing Office), 575-687.

1980. Early history of the diatom Family Asterolampraceae. Bacillaria, 3:227-272.

1983a. Middle Eocene diatoms from the south Atlantic. In Ludwig, W. J., Krasheninnikov, V. A., et al., Init. Repts. DSDP, 71 (Pt. 1): Washington (U.S. Govt. Printing Office), 565-581.

1983b. Survey of diatoms in the upper Oligocene and lower Miocene in Holes 515B and 516F. In Barker, P. F., Carlson, R. L., Johnson, D. A., et al., Init. Repts. DSDP, 72: Washington (U.S. Govt. Printing Office), 793-804.

Gombos, A. M., Jr., and Ciesielski, P. F., 1983. Late Eocene to early Miocene diatoms from the southwest Atlantic. In Ludwig, W. J., Krasheninnikov, V. A., et al., Init. Repts. DSDP, 71 (Pt. 2): Washington (U.S. Govt. Printing Office), 583-634.
Gregory, W., 1857. On new forms of Diatomaceae found in the Firth of Clyde and in Loch Fyne. Trans. R. Soc. Edinburgh, 21:473-542.

Greville, R. K., 1861-1866. Descriptions of new and rare diatoms. Ser. I-XX, Transactions of the Microscopical Society, London. Bibliotheca Phycologia, 6. (Reprinted 1966).

1882. On the Asterolampraceae of the Barbados deposit. Q. J. Microsc. Sci., N.S., 2:41-58.

Grove, E., and Sturt, G., 1887. On a fossil marine diatomaceous deposit from Oamaru, Otago, New Zealand. J. Quekett Miscrosc, Club, Ser. 2, 3:7-12, 63-78.

Grunow, A., 1884. Die Diatomeen von Franz-Josefs-Land. Denkschrift Math.-Nasw. Class Kaiserl. Akad. Wiss., 48:53-112.

Hajós, M., 1968. Die Diatomeen der Miozänen Ablagerungen des Mátavvorlandes. Geol. Hung., Ser. Paleontol., Fasculus 37.

1976. Upper Eocene and lower Oligocene Diatomaceae, Archaeomonadaceae, and Silicoflagellatae in southwestern Pacific sediments, DSDP Leg 29. In Hollister, C. D., Craddock, C., et al., Init. Repts. DSDP, 35: Washington (U.S. Govt. Printing Office), 817-883.

Hanna, G. D., 1927. The lowest known Tertiary diatoms in California. J. Paleontol., 1:103-127.

1932. The diatoms of Sharktooth Hill, Kern County, California. Proc. Calif. Acad. Sci., 4th Ser., 29:161-263.

Hargraves, P., 1968. Species composition and distribution of net plankton diatoms in the Pacific sector of the Antarctic Ocean [Ph.D. dissert.], Columbia Univ., New York.

Harwood, D. M., 1982. Oligocene-Miocene diatom biostratigraphy from the equatorial to the antarctic Pacific [M.S. thesis]. Florida State Univ., Tallahassee.

1986a. Diatom biostratigraphy and paleoecology with a Cenozoic history of antarctic ice sheets [Ph.D. dissert.]. Ohio State Univ., Columbus.

1986b. Diatoms. In Barrett, P. J. (Ed.), Antarctic Cenozoic History from the MSSTS-1 Drillhole, McMurdo Sound. DSIR Bull. N. Z., 237:69-107.

1986. Recycled siliceous microfossils from the Sirius. Formation. Antarctic J. U.S., 21:105-106.

1988. Upper Cretaceous and lower Paleocene diatom and silicoflagellate biostratigraphy of Seymour Island, eastern Antarctic Peninsula. In Feldman, R., and Woodburne, M. O. (Eds.), Geology and Paleontology of Seymour Island. Geol. Soc. Am. Mem., 169:55-129.

1989. Siliceous microfossils. In Barrett, P. J. (Ed.), Antarctic Cenozoic History from the CIROS-1 drillhole, McMurdo Sound. DSIR Bull. N. Z., 245:67-97.

1991. Cenozoic diatom biogeography in the southern high latitudes: inferred biogeographic barriers and progressive endemism. In Thompson, M.R.A., Crame, A., and Thompson, J. W. (Eds.), Geological Evolution of Antarctica: Cambridge (Cambridge Univ. Press), 667-673.

Harwood, D. M., Barrett, P. J., Edwards, T. A., Rieck, H. J., and Webb, P.-N., 1989. Biostratigraphy and chronology. In Barrett, P. J. (Ed.), Antarctic Cenozoic History from the CIROS-1 Drillhole, McMurdo Sound. DSIR Bull. N. Z., 245:231-239.

Harwood, D. M., Scherer, R. P., and Webb, P.-N., 1989b. Multiple Miocene productivity events in West Antarctic as recorded in upper Miocene sediments beneath the Ross Ice Shelf (Site J-9). Mar. Micropaleontol., 15:91-115.

Hasle, G. R., 1965. Nitzschia and Fragilariopsis species in the light and electron microscopes. III. The genus Fragilariopsis. Skr. Nor. Vidensk.-Akad. Kl. 1: Mat.-Naturvidensk Kl., 21:5-49.

1968. The valve processes of the centric diatom genus Thalassiosira. Nytt Mag. Bot., 15:193-201.

1972. Fragilariopsis Hustedt as a section of the genus Nitzschia Hassall. Nova Hedwigia Beih., 54:15-66.

Hasle, G. R., and Heimdal, B. R., 1970. Some species of the Centric diatom Genus Thalassiosira studied in the light and electron miroscopes. Nova Hedwigia Beih., 31:559-581.

Hasle, G. R., Heimdal, B. R., and Fryxell, G. A., 1971. Morphologic variability in fasciculated diatoms as exemplified by Thalassiosira tumida (Jan.) Hasle, comb. nov. In Llano, G. A., and Wallen, I. E. (Eds.), Biology of the Antarctic Seas IV: Antarct. Res. Ser., 17:313-333. 
Hasle, G. R., and Sims, P. A., 1986. The diatom genera Stellarima and Symbolophora with comments on the genus Actinoptychus. Br. Phycol. J., 21:97-114.

Hays, J. D., and Donahue, J. G., 1972. Antarctic Quaternary climatic record and radiolarian and diatom extinctions. In Adie, R. J. (Ed.), Antarctic Geology and Geophysics: Oslo (Scandin. Univ. Books), 733-738.

Heiberg, P.A.C., 1863. Conspectus Criticus Diatomacearum Danicarum: Kobenhavn (Wilhelm Priors Forlag).

Heiden, H., and Kolbe, R. W., 1928. Die marinen Diatomeen der Deutschen Südpolar-Expedition 1901-1903. In von Drygalski, E. (Ed.), Deutsche Südpolar-Expedition 1901-1903. Bd. 8, Botanik, 450-714.

Hendey, N. I., 1937. The plankton diatoms of the southern seas. Disc, Rep., 16:151-364.

1964. Bacillariophyceae (diatoms). An introductory account of the smaller algae of British coastal waters. Fish. Invest., Ser. 4, Pt. 5, London (HMSO).

1981. Miocene diatoms from the subantarctic southwest Pacific, DSDP Leg 29, Site 278, Core 10. Bacillaria, 4:65-124.

Hustedt, F., 1930-1933. Die Kieselalgen Deutschlands, Österreichs und der Schweiz mit Berücksichtigung der übrigen Länder Europas sowie der angrenzenden Gebiete. Teil 2. In Rabenhorst, L. (Ed.), Kryptogamen-Flora von Deutschland, Österreich und der Schweiz (Vol. 7): Leipzig (Akad. Verlag).

1958. Diatomeen aus der Antarktis und dem Südatlantik. Dtsch. Antarkt. Exped. 1938-1939, 2:103-191.

Johansen, J. R., and Fryxell, G. A., 1985. The genus Thalassiosira (Bacillariophyceae): studies on species occurring south of the Antarctic Convergence Zone. Phycologia, 24:155-179.

Jousé, A. P., 1959. The main phases in the development of the flora of marine diatoms in the Far Eastern Seas of the U.S.S.R. at the end of the Tertiary, and during the Quaternary. Botan. Zhurnal, 44:44-55.

1961. Miocene and Pliocene marine diatoms from the Far East. Bot. Mater. Spor. Rast., Bot. Inst. Akad. NAUK USSR, 16:59-70.

1968. Species novae Bacillariophytorum in sediments fundi Oceani Pacifici et Maris Ochotensis inventae. Noviates Syst. Plant. Non Vascul., 1968:12-21.

1974. Diatoms in the Oligocene-Miocene biostratigraphic zones of the tropical areas of the Pacific Ocean: Nova Hedwigia Beih., 45:333-364.

1977. Atlas of Microorganisms in Bottom Sediments of the Oceans (Diatoms, Radiolaria, Silicoflagellates and Coccoliths): Moscow (NAUKA). [In Russian].

1978. New fossil genus of diatoms (Lisitzinia (Bacillariophyta). Marsk. Mikropaleontol., 47-48.

Jousé, A. P., Koroleva, G. S., and Nagaeva, G. A., 1962. Diatoms in the surface layer of sediment in the Indian sector of the Antarctic. Tr. Inst. Okeanol., Akad. Nauk SSSR, 61:19-92.

1963. Stratigraphical and paleontological investigations in the Indian section of the Southern Ocean. Okeanol. Issled., 8:137-161.

Kanaya, T., 1957. Eocene diatom assemblages from the "Kellogg" and "Sidney" shales, Mt. Diablo Area, California. Sci. Rep. Tohoku Univ., Ser. 2, 28:27-124.

1959. Miocene diatom assemblages from the Onnagawa Formation and their distribution in correlative formations in northeast Japan. Sci. Rep. Tohoku Univ. Ser. 2, 30:1-130.

1971. Some aspects of pre-Quaternary diatoms in the Oceans. In Funnel, B., and Riedel, W. (Eds.), The Micropaleontology of Oceans: New York (Cambridge Univ. Press), 545-565.

Kanaya, T., and Koizumi, I., 1970. The progress in the Younger Cenozoic diatom biostratigraphy in the northern circum-Pacific Region. J. Mar. Geol., 6:47-66.

Karsten, G., 1905. Das Phytoplankton des Antarktischen Meeres. In Chun, C. (Ed.), Wissenschaftliche Ergebnisse der deut Schen Tiefsee-Expedition 1898-1899: Jena (Gustav Fischer), 1-136. 1928. Abteilung Bacillariophyta (Diatomeae). In Engler, A., and Prantl, K. (Eds.), Die natürlichen Pflanzenfamilien (Aufl. 2, Bd. 2), Peridineae (Dinofagellatae), Diatomeae (Bacillariophytha): Leipzig (Wilhelm Engelmann), 105-303.
Kellogg, D. E., and Kellogg, T. B., 1986. Diatom biostratigraphy of sediment cores from beneath the Ross Ice Shelf. Micropaleontology, 32:74-94.

Kim, W. H., and Barron, J. A., 1986. Diatom biostratigraphy of the upper Oligocene to lowermost Miocene San Gregario Formation, Baja California, Sur, Mexico. Diatom Res., 1:169-187.

Koizumi, I., 1968. Tertiary diatom flora of Oga Peninsula, Akita Prefecture, northeast Japan. Tokyo Univ. Sci. Rep., Ser. 2, 40:171-225.

1973. The Late Cenozoic diatoms of sites 183-192, Leg 19 , Deep Sea Drilling Project. In Creager, J. S., Scholl, D. W., et al., Init. Repts. DSDP, 19: Washington (U.S. Govt. Printing Office), 805-856.

1980. Neogene diatoms from the Emperor Seamount chain, Leg 55, Deep Sea Drilling Project. In Jackson, E. D., Koizumi, I., et al., Init. Repts. DSDP, 55: Washington (U.S. Govt. Printing Office), 387-407.

1982. Late Quaternary diatoms of the Bellingshausen Basin, Antarctic Ocean. Rept. Tech. Res. Cen. JNOC, 16:75-89.

Koizumi, I., and Tanimura, Y., 1985. Neogene diatom biostratigraphy of the middle latitude western North Pacific, Deep Sea Drilling Project Leg 86. In Heath, G. R., Burckle, L. H., et al., Init. Repts. DSDP, 86: Washington (U.S. Govt. Printing Office), 269-300.

Kolbe, R. W., 1954. Diatoms from equatorial Pacific cores. Rep. Swed. Deep-Sea Exped., 1947-1948, 6:1-58.

Komara, S., 1976. Sawamuraia, Katahiraia, Yoshidaia, drei neue Diatomgattungen aus dem Neogene Japans. Trans. Proc. Palaeontol. Soc. Jpn., N.S., 103:379-397.

Kozlova, O. G., 1966. Diatoms of the Indian and Pacific Sectors of the Antarctic. Acad. Sci. SSSR. Trans. Israel Program for Sci. Trans., TT66-51154. (Published in Russian, 1964).

Krebs, W. N., 1977. Ecology and preservation of neritic marine diatoms, Arthur Harbor, Antarctica [Ph.D. dissert.]. Univ. California, Davis.

Krotov, A. I., and Shibkova, K. G., 1959. Species novae diatomacearum e paleogeno montium uralensium. Botan. Mater. Otd. Sporovykh Rast., Botan. Inst., Akad. Nauk SSSR, 12:112129.

Macchiavello, J.C.M., and Lange, C., 1980. Diatomeas del Cenozoico al nordeste de la Peninsula Antarctica (en testigos E7-10 y E2231). Contrib. Inst. Antarct. Argent., 232:1-35.

Makarova, I. V., and Nikolaev, V. A., 1984. Notes on the Genus Schimperiella (Bacillariophyta). Bot. Z. USSR, 69:87-90. (in Russian).

Mangin, L., 1914. Sur le polymorphism de certaines Diatomées de l'Antarctique. Compt. Rend. Hebd. Seances Acad. Sci. Paris, 159:476-484.

1915. Phytoplankton de l'Antarctique. Deux. Exped. Antarct. Fr. (1908-1910), 2:1-95.

Mann, A., 1937. Diatoms. Scientific Reports of the Australia-Antarctic Expedition, 1911-1914. Sydney (Paisley), Sci. Rep. Ser. 1:182.

Maruyama, T., 1984. Miocene diatom biostratigraphy of onshore sequences on the Pacific side of northeast Japan, with reference to DSDP Hole 438A (Part 1). Tohoku Univ. Sci. Rep., Ser. 2, 54:141-164

McCollum, D. W., 1975. Diatom stratigraphy of the Southern Ocean. In Hayes, D. E., Frakes, L .A., et al., Init. Repts. DSDP, 28: Washington (U.S. Govt. Printing Office), 515-571.

O'Meara, E., 1877. On the Diatomaceous gatherings made at Kerguelen's Land by N. N. Moseley, M.A., H.M.S. Challenger. J. Linn. Soc. London Bot., 15:55-63.

Pantocsek, J., 1886-1892. Beiträge zur Kenntnis der Fossilen Bacillarien Ungarns (Vols. 1-3): Berlin (W. Junk).

Peragallo, M., 1921. Botanique. Première Partie. Diatomées d'eau douce. Deuxième Partie. Diatomées d'eau salée. Deux. Expéd. Antarct. Fr. 1908-1910, commandée par le Dr. Jean Charcot. Ouvrage Publié sous les Auspices du Ministère de I'Instruction Publique: Paris (Masson et Cie), 1-98.

Pritchard, A., 1861. A History of Infusoria, Living and Fossil: London (Wittaker and Co.).

Rattray, J., 1890. A revision of the genus Coscinodiscus and some allied genera. Proc. R. Soc. Edinburgh, 16:449-692. 
Reinhold, T., 1937. Fossil diatoms of the Neogene of Java and their zonal distribution. Verh. Geol. Mijnbouwkd. Genoot. Ned. Kolon., Geol. Ser., 12:1-132.

Sancetta, C., 1982. Distribution of diatom species in surface sediments of the Bering and Okhotsk seas. Micropaleontology, 28:221-257.

Savage, M. L., and Ciesielski, P. F., 1983. A revised history of glacial sedimentation in the Ross Sea. In Oliver, R. L., James, P. R., and Jago, J. B. (Eds.), Antarctic Earth Science: Cambridge (Cambridge Univ. Press), 555-559.

Scherer, R. P., 1989. Microfossil assemblages in "deforming till" from Upstream-B, West Antarctica: implications for ice stream flow models. Antarct. J. U.S., 24:54-55.

Scherer, R. P., Harwood, D. M., Ishman, S. E., and Webb, P.-N., 1988. Antarct. J. U.S., 23:34-36.

Schlich, R., Wise, S. W., Jr., et al., 1989. Proc. ODP, Init. Repts., 120: College Station, TX (Ocean Drilling Program).

Schmidt, A., Schmidt, M., Fricke, F., Heiden, H., Müller, O., and Hustedt, F., 1874-1959. Atlas der Diatomeen-Kunde. Leipzig (R. Reisland).

Schrader H.-J., 1973a. Cenozoic diatoms from the northeast Pacific, Leg 18. In Kulm, L. D., von Huene, R., et al., Init. Repts. DSDP, 18: Washington (U.S. Govt. Printing Office), 673-797.

1973b. Stratigraphic distribution of marine species of the diatom Denticula in Neogene North Pacific sediments. Micropaleontology, 19:417-430.

1974. Cenozoic marine planktonic diatom stratigraphy of the tropical Indian Ocean. In Fisher, R. L., Bunce, E. T., et al., Init. Repts. DSDP, 24: Washington (U.S. Govt. Printing Office), 887-967.

1976. Cenozoic planktonic diatom biostratigraphy of the Southern Pacific Ocean. In Hollister, C. D., Craddock, C., et al., Init. Repts. DSDP, 35: Washington (U.S. Govt. Printing Office), 605-672.

Schrader, H.-J., and Fenner, J., 1976. Norwegian Sea Cenozoic diatom biostratigraphy and taxonomy. In Talwani, M., Udintsev, G., et al., Init. Repts. DSDP, 38: Washington (U.S. Govt. Printing Office), 921-1099.

Schulz, P., 1935. Diatomeen aus Seenonen Schwammgesteinen der Danziger Bucht. Zugleich ein Beitrag zur Entwicklungsgeschichte deer diatomeen. Bot. Archiv., 37:383-413.

Sheshukova-Poretzkaya, V. S., 1962. New and rare Bacillariophyta from diatom series of Sakhalin Island. Uch. Zap., Igu. Ser. Biol. Nauk (Leningrad Univ.), 49:203-211.

1967. Neogene Marine Diatoms of Sakhalin and Kamchatka: Leningrad (Leningrad Univ.).

Sheshukova-Poretzkaya, V. S., and Gleser, S. I., 1964. Diatomeae marinae novae e paleogeno Ukrainiae. Novosti Systematiki Nizschich Rast. Otdel Benbii Ottisk Isdatelbstvo: Moscow (Nauka), 78-92.

Simonsen, R., 1979. The diatom system: ideas on phylogeny. Bacillaria, 2:9-71.

1982. Notes on the diatom genus Charcotia M. Peragallo. Bacillaria, 5:101-116.

Simonsen, R., and Kanaya, T., 1961. Notes on the marine species of the diatom genus Denticula Kutz. Int. Rev. Ges. Hydrobiol., 46:498-513.

Sims, P. A., 1986. Sphynctolethus Hanna, Ailuretta gen. nov., and evolutionary trends within the Hemiauloideae. Diatom Res. $1: 241-269$.

Sims, P. A., and Ross, R., 1990. Triceratium pulvinar and T. unguiculatum, two confused species. Diatom Res., 5:155-169.

Steinhauff, D. M., Renz, M. E., Harwood, D. M., and Webb, P.-N., 1987. Miocene diatom biostratigraphy of DSDP Hole 272: stratigraphic relationship to the underlying Miocene of DSDP Hole 270, Ross Sea. Antarct. J. U.S., 22:123-124.

Strelnikova, N. I., 1974. Diatoms of the Late Cretaceous: Moscow (NAUKA). (in Russian)

Sündstrom, B. G., 1986. The marine diatom genus Rhizosolenia. A new approach to the taxonomy [Ph.D. thesis]. LUNDBS/NBB1008. Univ. Lund, Sweden.

Syvertsen, E. E., and Hasle, G. R., 1983. The diatom genus Eucampia: morphology and taxonomy. Bacillaria, 6:169-210.
Tauxe, L., Tucker, P., Petersen, N. P., and LaBrecque, J. L., 1984. Magnetostratigraphy of Leg 73 sediments. In Hsü, K. J., LaBrecque, J. L., et al., Init. Repts. DSDP, 73: Washington (U.S. Govt. Printing Office), 609-621.

Tempère, J., 1890. Diatomées rares ou nouvelles. Le Diatomiste, $1: 30-34$

Van Heurck, H., 1880-1885. Synopsis des Diatomées de Belgique: Anvers (F.J. Dieltjens).

1896. A Treatise on the Diatomaceae: London (W. Wesley and Co.). Trans. by W. E. Baxter.

1909. Expédition Antarctique Belge. Résultats du Voyage du S.Y. "Belgica" en 1897-1899, Botanique, Diatomées: Anvers (J. E. Buschmann).

Villareal, T. A., and Fryxell, G. A., 1983. The genus Actinocyclus (Bacillariophyceae): frustule morphology of A. sagittulus sp. nov. and two related species. J. Phycol., 19:452-466.

Weaver, F. M., and Gombos, A. M., 1981. Southern high-latitude diatom biostratigraphy. In Warme, T. E., Douglas, R. G., and Winterer, E. L. (Eds.), The Deep Sea Drilling Project: A Decade of Progress. Spec. Publ. Soc. Econ. Paleontol. Mineral., 32:445470.

Whiting, M. C., and Schrader, H., 1985. Actinocyclus ingens Rattray: reinvestigation of a polymorphic species. Micropaleontology, 31:68-75.

Yanagisawa, Y., and Akiba, A., in press. Taxonomy and phylogeny of the three marine diatom genera Crucidenticula, Denticulopsis, and Neodenticula. Chishitsu Chosasho Geppo.

Date of initial receipt: 22 May 1990

Date of acceptance: 26 June 1991

Ms 120B-160

\section{APPENDIX}

\section{Taxonomic Notes And Floral References}

Taxonomic references for diatom species identified from Leg 120 sediments are listed below. The author of each species is listed as well as several good references that describe and illustrate the particular taxon. Preference was given to Antarctic literature in these citations, and to papers with good illustrations or detailed synonymies. New diatom taxa, new combinations and diatoms treated with informal nomenclature are given in Table 18. Additional descriptions, illustrations, and discussions of new taxa will be provided in subsequent papers. The 19 plates are arranged in relative stratigraphic order, with Eocene to lower Miocene diatoms in Plates 1-5, Miocene diatoms in Plates 5-12, and Pliocene and Pleistocene diatoms in Plates 12-19.

Actinocyclus actinochilus (Ehrenberg) Simonsen, 1982, pp. 101-116, pls. 1-4; Villareal and Fryxell, 1983, p. 461, figs. 21-32

Basionym. Coscinodiscus actinochilus Ehrenberg, 1844, p. 200; Ehrenberg, 1854, pl. 35A, fig. XXI, 5.

Synonyms. Anisodiscus apollinis Brown, 1920; Charcotia actinochilus. 78; Hustedt, 1958, pp. 122-126, pl. 7, figs. 57-80

Actinocyclus sp. cf. A. actinochilus (older form)

Discussion. Older forms of diatoms with similar structure to $A$. actinochilus, but with much closer spacing between the radial lines of punctae and a greater number of lines, and present near the lower range of $A$. actinochilus s.s. The limited recovery of $A$. actinochilus s.s. near the base of its range did not allow us to observe the transition between these two forms, if one in fact exists. See illustration in Jousé et al., 1963.

Synonyms. Actinocyclus actinochilus sensu Harwood, 1986a, pl. 16, figs. 6(?) and 7-9; Actinocyclus karstenii sensu Harwood, 1986a (in part), pl. 24, fig. 7, and pl. 27, figs. 3 and 5-6. (Plate 12, Figs. 9-11)

Actinocyclus curvatulus Janisch, 1878 in Schmidt et al., 1874-1959,

pl. 57, fig. 31; Hustedt, 1930, p. 538, fig. 307; Hustedt, 1958, p. 129 ,

pl. 8, figs. 82-83; Akiba, 1982, pp. 41-42, pl. 5, figs. 5a-6.

Synonyms. Actinocyclus divisus (Grunow) Hustedt, 1958, p. 129, pl. 7, fig. 81; Actinocyclus radiatus var. in Van Heurck, 1909, pl. 12, fig. 157. (Plate 12, Fig. 12) 
Actinocyclus dimorphus (Castracane) comb. nov.

Basionym. Coscinodiscus(?) dimorphus Castracane, 1886, p. 157, pl. 17, fig. 6

Synonym. Cestodiscus sp. McCollum, 1975, pl. 3, figs. 1-2; Actinocyclus ingens Harwood, 1986a, pl. 16, figs. 3-4. (Plate 12, Fig. 16?, Plate 13, Figs. 3-5, Plate 17, Figs. 19-20)

Actinocyclus ellipticus Grunow in Van Heurck, 1881; Hustedt, 1930, p. 533 , fig. 303 ; Schrader, 1974, p. 908 , pl. 17

Actinocyclus fasciculatus sp. nov.

Synonym. Cestodiscus sp. 6 of Schrader, 1976, pl. 12, fig. 4

Description. Valve circular, gently convex; areolar pattern radial fasciculate ( 8 in $10 \mu \mathrm{m}$ ), parallel to longest row in center of fascicle; radial hyaline areas, generally from 3 to 6 per valve, the width of one row of areolae providing clear separation of fascicles from the margin to a central hyaline area, which possesses disordered areolae; pseudonodulus distinct at the valve margin.

Remarks. Not observed in SEM.

Holotype. USNM Collection 458220 (Plate 13, Fig. 14)

Paratype. USNM Collection 458221 (Plate 13, Fig. 15)

Type level and locality. mid-Pliocene, Sample 120-751A-2H-2, 10-11 cm, Kerguelen Plateau. (Plate 13, Figs. 14-15)

Actinocyclus ingens Rattray, 1890, p. 149, pl. 11, fig. 7; Kanaya, 1971, p. 554 , figs. 1-8; Gombos, 1977 , p. 592 ; Baldauf and Barron, 1980 , pl. 1, figs. 1-4; Akiba, 1982, p. 42, pl. 5, figs. 7-14; Whiting and Schrader, 1985; Akiba and Yanagisawa, 1986, p. 494, pls. 34-35; Gersonde, 1990, pp. 791-792. (Plate 8, Fig. 10, Plate 11, Figs. 4 and 6, and Plate 12, Fig. 8)

Actinocyclus ingens var. nodus Baldauf, in Baldauf and Barron, 1980, p. 104, pl. 1, figs. 5-9; Ciesielski, 1986, pl. 1, figs. 8-9; Gersonde, 1990 , p. 792

Actinocyclus ingens var. irregularis n. comb.

Basionym. Actinocyclus irregularis Van Heurck 1909, p. 44, pl. 12, fig. 159

Discussion. This taxon may reflect a smaller ecophenotypic variant of Actinocyclus ingens. Distribution tables show the presence of either $A$. ingens or $A$. ingens var. irregularis at different intervals.

\section{Actinocyclus ingens var. A}

Remarks. This diatom is closely allied to Hemidiscus ovalis (Gersonde) n. comb., but differs in that it possesses a circular rather than an oval shape and lacks a cuneate form in the girdle view where one side of the mantle is higher than the other side. This diatom was confused with Cosmiodiscus insignis in the Initial Reports of Legs 119 and 120. The hyaline central area is of non-uniform thickness, as indicated by the irregular, labyrinthic shadows (Plate 12, Fig. 5), which are also visible in some specimens of Hemidiscus ovalis (Gersonde) n. comb. (Plate 12, Fig. 1). A pseudonodulus is clearly visible in most specimens. The similarity of this diatom to $H$. ovalis raises the question whether the cuneate form is a valid characteristic to use in separating Hemidiscus from Actinocyclus. In general, shape is not a sufficiently valid character to differentiate among genera (Plate 12, Figs. 4-5).

Actinocyclus karstenii Van Heurck, 1909, p. 44, pl. 12, fig. 158; Harwood, 1986b, p. 94, pl. 8, figs. 8-10

Synonyms. Actinocyclus polysculptus Mann, 1937, pl. 1, figs. 1-3; Cestodiscus sp. 1 of Schrader, 1976, pl. 12, fig. 6; Actinocyclus curvatulus sensu Harwood, 1986a, pl. 16, figs. 1-2; Actinocyclus fryxellae Barron, in Baldauf and Barron, 1991, pl. 1, figs. 1-2 and 4. (Plate 13, Figs. 1, 2, 6-8, 10, 11, and 13)

Actinocyclus maccollumii sp. nov.

Synonym. Coscinodiscus? sp. 3, in McCollum, 1975, p. 527, pl. 7, figs. 1-4

Description. Valves circular, flat to slightly convex; margin striate with ring of fine perforations, $2-3$ wide, at valve edge; valve face covered with areolae in subradial rows that are interrupted by the presence of several (2-5) labiate(?) processes located near midradius, around which the rows of areolae curve; pseudonodulus distinct at valve margin.
Remarks. The structures described above are best illustrated in McCollum, 1975, pl. 7.

Holotype. USNM Collection 458222 (Plate 17, Fig. 29)

Type level and locality. mid-Pliocene, Sample 120-751A-2H-2, 10-11 cm, Kerguelen Plateau

Discussion. McCollum was uncertain to which genus this species belonged. His illustrations clearly show the presence of a pseudonodule, and thus placement within Actinocyclus is probably correct, although the multiple subcentral processes are unknown from Actinocyclus and may suggest placement in a different (new?) genus. Species not observed in SEM. (Plate 17, Fig. 29)

Actinocyclus octonarius Ehrenberg; Hustedt, 1930, pp. 525-528, fig. 289

Actinocyclus octonarius Ehrenberg var. tenella (Brebisson) Hustedt, 1930 , pp. $530-533$, fig. 302 ; Maruyama, 1984, pl. 13, fig. 10

Actinocyclus sp. A (Plate 5, Fig. 12)

Actinocyclus sp. B (Plate 13, Figs. 9 and 12)

Actinocyclus sp. C

Synonym. Actinocyclus karstenii sensu Harwood, 1986a (in part), pl. 27, fig. 4, not figs. 3 and 5-6. (Plate 12, Figs. 13-14)

Actinocyclus sp. cf. A. ochotensis Jousé, 1968, p. 17, fig. 2, nos. 2 and 5; Sancetta, 1982 , p. 224 , pl. 1, figs. 4-6

Actinoptychus senarius (Ehrenberg) Ehrenberg; Hendey, 1964, p. 95, pl. 23, figs. 1-2; Kanaya, 1957, p. 98, pl. 7, fig. 117

Synonym. Actinoptychus undulatus (Bailey) Ralfs in Pritchard, 1861; Hustedt, 1930 , pp. $475-478$, fig. 264

Actinoptychus thumii Hanna, 1932, p. 171, pl. 4, figs. 3-4

Asterolampra affinis Greville, 1862, p. 48, pl. 8, figs. 26-27; Schmidt et al., 1874, pl. 137, fig. 4; Schrader, 1974, p. 911, pl. 9, fig. 10; Gombos, 1983a, pl. 1, fig. 1

Asterolampra gradiata Gombos, in Gombos and Ciesielski, 1983, p. 606 , pl. 1 , figs. $4-6$

Asterolampra grevillei (Wallich) Greville, 1860; Hustedt, 1930, p. 489, fig. 274; Gombos, 1980 , p. 568 , pl. 1, fig. 2; Gombos and Ciesielski, 1983 , p. 600

Asterolampra punctifera (Grove) Hanna 1927, p. 109, pl. 17, fig. 3; Gombos and Ciesielski 1983 , p. 600 , pl. 2, figs. 4-8, and pl. 5, figs. $8-10$; Harwood, 1989 , p. 77 , pl. 5, figs. $1-2$

Basionym. Asterolampra affinis var. punctifera Grove in Schmidt et al., 1874-1959, pl. 202, fig. 18

Asterolampra schmidtii Hajós, 1976, p. 827, pl. 21, fig. 6; Gombos and Ciesielski, 1983 , p. 600 , pl. 2 , figs. $1-3$, and pl. 4 , figs. 9-10

Synonym(?). Asterolampra insignis Schmidt et al., 1888, pl. 137, figs. 1-3; Gombos, 1980 , pp. 235-236, pl. 10, fig. 48 , and pl. 13, fig. 52

Asterolampra tela Gombos and Ciesielski, 1983, p. 604, as Asterolampra sp. A, but in pl. 3, figs. 1-4, as Asterolampra tela

Remarks. The diatom illustrated in Plate 4, Figure 16, bears a short, incomplete "primary ray" similar to the genus Asteromphalus. Asterolampra tela could be part of a lineage that gave rise to the younger genus Asteromphalus during the early Oligocene, as outlined in Gombos (1980). (Plate 4, Fig. 16)

Asterolampra uraster Grove and Sturt, 1887, p. 143, pl. 13, fig. 42; Gombos, 1983 a, p. 569 , pl. 1, figs. 4-8

Asterolampra vulgaris var. cellulosa Greville, 1862, p. 47, pl. 7, figs. 17-20; Gombos and Ciesielski, 1983, p. 600, pl. 1, figs. 1-3. (Plate 1, Fig. 7)

Asterolampra vulgaris var. hyalina Gombos, in Gombos and Ciesielski, 1983, p. 606, pl. 1, figs. 3 and 9. (Plate 2, Fig. 17)

Asteromphalus concavus sp. nov.

Description. Valve circular, slightly convex; areolared segments between hyaline rays of unequal size, smallest opposite primary ray; areolated segments surrounding primary ray of unequal size, as primary ray angles closer to one adjacent ray; sutures between central portions of hyaline rays straight and unbranching, with only a minor 
hint of "zigzag" structure at mid-length; inner border of areolar segments concave to broadly rounded toward valve margin, except for two segments adjacent to primary ray that are angularly concave.

Remarks. This species differs from $A$. parvulus by (1) radiating sutures between hyaline sectors that are straight with only minor "zigzags;" (2) inner margins of areolated segments that concave outward, but are straight to broadly convex toward the margin in $A$. parvulus; and (3) the different, older stratigraphic range of this species.

Holotype. USNM Collection 458223 (Plate 19, Fig. 3)

Paratype. USNM Collection 458224 (Plate 19, Fig. 4)

Type level and locality. upper Miocene, Sample 120-751A-5H-4, 105-106 cm, Kerguelen Plateau. (Plate 19, Figs. 3-4)

Asteromphalus hookeri Ehrenberg, 1844, Hustedt, 1930, pp. 496-498, fig. 278; Hustedt, 1958 , p. 127 , pl. 8, figs. 88-90

Synonym. Asteromphalus robustus Castracane, 1886.

Asteromphalus hyalinus Karsten, 1905; Hustedt, 1958, p. 128, pl. 8, figs. 84-87; Fenner et al., 1976, pl. 4, figs. 17-19

Asteromphalus inaequabilis Gersonde, 1990, p. 792, pl. 2, fig. 4, and pl. 6 , fig. 3

Synonyms. Asteromphalus sp. 2 of Schrader, 1976, pl. 8, fig. 1, but not pl. 8, fig. 2. (Plate 5, Figs. 1-2)

Asteromphalus kennettii Gersonde, 1990, p. 793, pl. 2, fig. 1, and pl. 6, fig. 2; Gersonde and Burckle, 1990, pl. 5, fig. 6

Synonym. Asteromphalus sp. 1 of Ciesielski, 1983, p. 655 , pl. 6 , figs. 1, 2, 6, and 9. (Plate 11, Fig. 3)

Asteromphalus parvulus Karsten, 1905, p. 90, pl. 8, fig. 14; Hustedt, 1958, p. 128, pl. 8, fig. 91; Abbott, 1974, p. 310, pl. 2, fig. B; Fenner et al., 1976, p. 769, pl. 4, figs. 17-19; Akiba, 1982, p. 42, pl. 1, figs. 3,5 , and 6. (Plate 19, Figs. 1-2)

Asteromphalus oligocenicus Schrader and Fenner, 1976, pp. 965-966, pl. 21, figs. 8,13 , and 14 , and pl. 28, fig. 1; Gombos and Ciesielski, 1983 , p. 600 , pl. 5, fig. 11 ; Kim and Barron, 1986, pl. 2, fig. 7 ; Harwood, 1986a, p. 85, pl. 1, figs. 1-2

Synonym. Asteromphalus sp. 2 of Schrader, 1976, p. 630, pl. 8, fig. 2, but not pl. 8, fig. 1. (Plate 4, Fig. 17, and Plate 5, Fig. 5)

Asteromphalus symmetricus Schrader and Fenner 1976, p. 966, pl. 21, figs. 7 and 10-12; Harwood, 1986b, p. 85, pl. 1, figs. 1-2; Harwood et al., 1989b, pl. 2, fig. 4

Synonym. Asteromphalus parvulus sensu Schrader, 1976, pl. 8, figs. 3 and 6. (Plate 4, Fig. 18)

Asteromphalus sp. A. (Plate 5, Figs. 3-4)

Azpeitia antiqua (Pantocsek) Sims in Fryxell et al., 1986, p. 6

Azpeitia gombosi sp. nov.

Synonym. Stictodiscus sp. of Gombos and Ciesielski, 1983, p. 605, pl. 22, figs. 7-8

Description. Valve circular, flat; areolae rows (6-7 areolae in 10 $\mu \mathrm{m})$ radial, straight near margin, and gradually bending to converge at an eccentric position where a hyaline space is usually present; subcentral process (labiate?) near ring of areolae that surround eccentric hyaline area; margin narrow, surrounded by ring of small pores $(10-12$ in $10 \mu \mathrm{m})$.

Remarks. Not examined in SEM. This new form bears some similarity to the older Paleogene species Azpeitia biradiata and A. elegantula. See illustrations in Fryxell et al. (1986).

Holotype. USNM Collection 458225 (Plate 3, Fig. 1)

Paratype. USNM Collection 458226 (Plate 3, Fig. 2)

Type level and locality. upper Oligocene, Sample 120-747A-16H-7, 47-49 cm, Kerguelen Plateau. (Plate 3, Figs. 1-2)

Azpeitia nodulifer (A. Schmidt) Fryxell and Sims, in Fryxell et al., 1986, p. 19, Figs. XVII, XVIII-1 through XVIII-3, XVIII-5, and XXX-3 through XXX-4

Azpeitia oligocenica (Jousé, 1974) Sims, in Fryxell et al., 1986, p. 16, figs. 6-8

Basionym. Coscinodiscus oligocenicus Jouse, 1974, p. 348, pl. 1, figs. 6-8 and 16; Fenner, 1979, p. 515, pl. 4, figs. 5-10; Gombos, 1983a, p. 569 , pl. 2 , figs. 1-4; Harwood, 1986 b, p. 85 , pl. 2 , figs. 1-3. (Plate 3, Fig. 3)

Azpeitia tabularis (Grunow, 1884) Fryxell and Sims, in Fryxell et al., 1986 , p. 16, figs. XIV, XV, and XXX-I

Basionym. Coscinodiscus tabularis Grunow, 1884, p. 86; Hustedt, 1958 , p. 119 , pl. 6, figs. 48-56; Hargraves, 1968, p. 50, figs. 76-78; Abbott, 1974, p. 312, pl. 3, figs. A-C; Fenner et al., 1976, p. 774, pl. 7, figs. 10-13; Akiba, 1982, p. 42, pl. 2, figs. 6-10; Fenner, 1984b, p. 1263

Synonyms. Azpeitia endoi (Kanaya) Sims and Fryxell in Fryxell et al., 1986, p. 16; Coscinodiscus endoi Kanaya, 1957, p. 76, pl. 3, figs. 8-11; Coscinodiscus nodulifer sensu McCollum, 1975, p. 527, pl. 5, figs. 7-8. (Plate 11, Fig. 5)

Baxteriopsis brunii (Van Heurck, 1893) Karsten, 1928, pp. 249-250, fig. 30; Fenner, 1985 , p. 727 , figs. 10.7-10.8

Basionym. Baxteria brunii Van Heurck, 1893, p. 460, fig. 190; Gombos and Ciesielski, 1983, p. 600, pl. 21, figs. 5-7. (Plate 2, Fig. 11)

Bogorovia veniamini Jouse, 1974, p. 351, pl. 4, figs. 1-3

Brightwellia coronata (Brightwell) Ralfs in Pritchard, 1861, p. 940

Synonym(?). Brightwellia pulchra Grunow in Van Heurck, 1883, pl. 128, fig. 9; Gombos, 1977, p. 592, pl. 27, figs. 3-4. (Plate 1, Fig. 8)

Brightwellia hyporborea Grunow in Van Heurck, 1883, pl. 128, fig. 8; Fenner, 1985, p. 727 , fig. 7.24

Brightwellia spiralis Gleser, in Sheshukova-Poretzkaya and Gleser, 1964, p. 82, pl. 2, fig. 3; Gombos and Ciesielski, 1983, p. 600, pl. 23 , figs. $1-3$

Cestodiscus antarcticus Fenner, 1984a, pl. 1, fig. 1

Cestodiscus convexus Castracane, 1886, p. 123, pl. 7, fig. 6

Synonym. Cestodiscus pulchellus Greville, sensu Jousé, 1974, p. 345 , pl. 1, figs. $12-13$

Cestodiscus pulchellus Greville, 1866, p. 123, pl. 11, fig. 5; Barron, 1985 a, p. 780 , figs. 10 and 15

Remarks. The specimens illustrated here bear resemblance to Actinocyclus octonarius var. tenella, but they lack the obvious pseudocellus. (Plate 3, Figs. 6-7)

Cestodiscus pulchellus var. novazealandica Grove, 1890, in Schmidt et al., 1874-1959, pl. 148, fig. 7, and pl. 163, figs. 8 and 10

Remarks. This diatom occurs near the Eocene/Oligocene boundary, as noted by Fenner (1985). (Plate 1, Fig. 4)

Cestodiscus reticulatus Fenner, 1984b, p. 1261, pl. 1, fig. 10

Synonym. Coscinodiscus superbus Hardmann sensu Fenner, 1978, pl. 14, figs. 2-3, but not figs. 1 and 4. (Plate 3, Fig. 4)

Cestodiscus trochus Castracane, 1886, p. 123 , pl. 7, figs. 1 and 3; Fenner, 1984b, p. 1261, pl. 1, figs. 3-4

Synonym. Cestodiscus mukhinae Jousé, 1974, pp. 344-345, pl. 1, figs. $1-5$

\section{Cestodiscus sp. (Plate 1, Fig. 5)}

Chaetoceros bulbosum (Ehrenberg) Heiden, in Heiden and Kolbe, 1928 , p. 526, pl. 9, fig. 171; Frenguelli, 1960, p. 36, pl. 2, fig. 8; Jousé et al., 1977a, pl. 68, fig. 23, and pl. 71, fig. 13; Krebs, 1977, p. 157 , pl. 2 , fig. 8

Chaetoceros sp. A. (Plate 19, Figs. 5-7)

Corethron criophilum group Castracane, 1886, p. 85; Hargraves, 1968 , p. 38 , figs. $54-60$

Remarks. The genus Corethron is known from Antarctic sediments from the upper Oligocene (Harwood, 1989) and Miocene to Holocene (this paper), in contrast to many statements that this genus always dissolves before reaching the seafloor. In fact, nearly monospecific oozes of Pliocene/Pleistocene Corethron occur in thin laminae from the Wilkes Land continental margin (Harwood, unpubl. notes). (Plate 19, Figs. 8-11, and Plate 5, Fig. 15)

Coscinodiscus apiculatus Schmidt et al., sensu McCollum, 1975, p. 526 , pl. 4 , figs. $1-2$ 
Coscinodiscus hajosiae Fenner, 1984a, pl. 2, fig. 1

Synonym. Coscinodiscus spiralis Hajos, 1976, p. 826, pl. 7, figs. 1-3, not $C$. spiralis Karsten, 1905. This species probably does not belong in Coscinodiscus.

Coscinodiscus lewisianus Greville, 1866, p. 78, pl. 8, figs. 8-10

Remarks. The group of diatoms represented by $C$. lewisianus, $C$. rhombicus, and other similar diatoms is clearly out of place within Coscinodiscus, and a new genus should be erected for this group. This is beyond the scope of this paper. Diatoms that should be treated as distinct species are listed here as varieties, awaiting detailed study and placement in a new genus. Allied genera include Cestodiscus, Actinocyclus, and Kozloviella. (Plate 6, Fig. 13)

Coscinodiscus lewisianus var. levis (Jousé, 1974)

Basionym. Actinocyclus levis Jousé, 1974, p. 353, pl. 5, fig. 2; Jousé, 1977, pl. 53, fig. 4

Synonym. Cestodiscus ovalis Harwood, 1986b, p. 85, pl. 1, figs. 13-14; Cestodiscus sp. 1 of Schrader, 1976, pl. 5, fig. 17; Coscinodiscus lewisianus? Schrader and Fenner, 1976, pl. 21, fig. 6; Harwood, 1982, pl. 14, fig. 8; Actinocyclus sp. cf. levis Jousé, Harwood, 1989, pl 5, fig. 2. See comments above in C. lewisianus. (Plate 3, Figs. 12-15)

Coscinodiscus lewisianus var. rhomboides Barron, 1985a, p. 443, pl. 7 , figs. $2-3$

Coscinodiscus lewisianus var. robustus Barron, Barron, 1985a, pl. 7, fig. 11. (Plate 3, Figs. 8-9)

Coscinodiscus marginatus Ehrenberg; Hustedt, 1930, p. 416-418, fig. 223

Coscinodiscus rhombicus Castracane, 1886, p. 164, pl. 22, fig. 11; Fenner, 1985, p. 729, figs. 7.1-7.4; Kim and Barron, 1986, pl. 3, fig. 7. (Plate 3, Figs. 16-17, Plate 8, Figs. 12-13, and Plate 11, Fig. 1)

Coscinodiscus superbus Hardmann in Rattray, 1890, p. 458; Gombos and Ciesielski, 1983, p. 603, pl. 4, figs. 1-8

Synonym. C. robustus Jousé, 1974, p. 345, pl, 1, figs. 14-15

Crucidenticula ikebei Akiba and Yanagisawa, 1986, p. 485, pl. 1, figs. 1-2.

Basionym. Denticula ikebei Akiba ex Barron, 1980, p. 672, pl. 1, fig. 30 , nom. invalid.

Crucidenticula kanayae Akiba and Yanagisawa, 1986, p. 486, pl. 1 , figs. 3-8, and pl. 3, figs. 1-6, 9, and 11

Basionym. Denticula kanayae Akiba ex Barron 1980, p. 672, pl. 1, figs. 26-28. (Plate 7, Fig. 15)

Crucidenticula nicobarica (Grunow) Akiba and Yanagisawa, 1986, p. 486 , pl. 1 , fig. 9 , pl. 2 , figs. $1-7$, and pl. 5, figs. 1-9

Basionym. Denticula nicobarica Grunow; Schrader, 1973b, pl. 1, figs. $31-35$ 65

Synonym. Denticulopsis nicobarica (Grunow) Simonsen, 1979, p.

Dactyliozolen antarcticus Castracane, 1886, p. 75, pl. 9, fig. 7; Hendey, 1937, pl. 6, figs. 1-3; Hargraves, 1968, p. 54, figs. 85-86; Krebs, 1977, p. 165, pl. 6, fig. 1; Jousé et al., 1977, pl. 69, fig. 22

Synonym. Genus et species indet. (D) Gombos, 1977, pl. 10, figs. 1-3. (Plate 18, Fig. 12)

Denticulopsis dimorpha (Schrader) Simonsen, 1979, emend. Akiba and Yanagisawa, 1986, p. 488, pl. 15, figs. 1-25, and pl. 16, figs. $1-11$

Basionym. Denticula dimorpha Schrader, 1973b, p. 704, pl. 1, figs. 37-46. (Plate 6, Figs. 5-7; Plate 7, Fig. 10; Plate 9, Figs. 5-9, 15-18, 22, and 23; and Plate 10, Figs. 5, 6, 12, and 14)

Denticulopsis dimorpha var. areolata Yanagisawa and Akiba, in press Synonym. Denticulopsis dimorpha sensu Akiba, 1986, pl. 27, figs. $1,2,5,6$, and 10

Remarks. This variety is included to $D$. dimorpha in this paper.

Denticulopsis hustedtii (Simonsen and Kanaya) Simonsen, 1979; Akiba and Yanagisawa, 1986, p. 488, pl. 17, figs. 4, 5, and 7-23; pl.
18 , figs. $1-10$; pl. 19 , figs. $1-5$ and $8-9$; pl. 7 , figs. $16-29$; and pl. 9, figs. $1-9$

Basionym. Denticula hustedtii Simonsen and Kanaya, 1961, p. 501 , pl. 1, figs. 19-25.

Remarks. Copulae of this taxon almost always show open bands, but closed bands are detected sporadically from the upper Miocene interval. (Plate 7, Fig. 14; Plate 8, Figs. 1-3 and 16; Plate 9, Figs. 19-21; and Plate 10, Figs. 3, 13, and 17?)

Denticulopsis hustedtii var. aspera Maruyama, in Harwood and Maruyama, var. nov.

Description. Valves strongly silicified, elliptical with broadly rounded ends, 14-33 $\mu \mathrm{m}$ long, 7-8 $\mu \mathrm{m}$ wide. Approximately 2-3 primary pseudosepta per $10 \mu \mathrm{m}$ are present along the pervalvar axis. The secondary pseudosepta are 1-3 in between the primary pseudosepta. The density of all pseudoseptae (primary and secondary) is 6-7 per $10 \mu \mathrm{m}$ along the pervalvar axis. The valve face is thickly silicified and covered by coarse ornamentation of numerous large deep depressions and excavations.

Discussion. This taxon is proposed as a variety of Denticulopsis hustedtii because it possesses secondary pseudosepta. This variety differs from the typical $D$. hustedtii s.s. by the roughness of the valve face and the absence of fine and regular punctation. Morphostructure of the valve, except for valve face, is quite similar to that of $D$. hustedtii s.s. Neither morphology of copula nor structure of theca is distinct in the paper. This taxon has not been reported from the North Pacific and is interpreted accordingly as being endemic to the Southern Ocean. A similar diatom and perhaps the same diatom is described as $D$. dinychara areolata by Yanagisawa and Akiba (in press).

Holotype. Plate 10, Figure 10, Sample 120-751A-7H-1, 105-106 $\mathrm{cm}$. IGPS Collection No. G5-183 deposited in the Museum of Yamagata University.

Stratigraphic range. middle late Miocene. The stratigraphic range is limited to the middle part of the Denticulopsis hustedtii.Zone.

Derivation of name. The name represents the asperities of the valve face. (Plate 10, Figs. 8-11 and 15-16)

Denticulopsis hustedtii var. ovata (Schrader) Simonsen, 1979, p. 64

Basionym. Denticula hustedtii var. ovata Schrader, 1976, pl. 4, Figs. 12 and 14-15 (revised here as Denticulopsis meridionalis sp. nov., see above); Denticulopsis hustedtii (elliptical form) sensu Maruyama, 1984, pl. 13, figs. 1a-b, 2a-b, and 3, and pl. 16, figs. 4-5

Remarks. This variety, as well as the typical $D$. hustedtii, has a deck bearing pedestal-like processes named "tsuzumis" in order to connect or couple with a copula. Processes, each of which take the form of a butterfly or hourglass, are silhouetted through the valve face in external view of valve and/or theca. Differs from $D$. meridionalis sp. nov. by the presence of processes. (Plate 7, Fig. 5, and Plate 8, Figs. 4, 9, 11, and 14-15)

Denticulopsis hyalina (Schrader) Simonsen; Akiba and Yanagisawa, 1986, pl. 10, figs. 1-16, pl. 11, figs. 1-10, and pl. 12, figs. $1-5$

Basionym. Denticula hyalina Schrader, 1973b, p. 704, pl. 1, figs. 12-22. (Plate 10, Fig. 4)

Denticulopsis lauta (Bailey) Simonsen, 1979; Akiba and Yanagisawa, 1986 , p. 489 , pl. 7 , figs. $16-29$, and pl. 9, figs. 1-9

Basionym. Denticula lauta Bailey; Simonsen and Kanaya, 1961, p. 500 , pl. 1 , figs. $1-5$

Remarks. In the cases of missing deck and/or copula, isolated valves of both $D$. praedimorpha and $D$. dimorpha are identified as $D$. lauta s.l., because conclusive characters were not yet reported to differentiate them from those of $D$. lauta s.s.

Denticulopsis maccollumii Simonsen, 1979, p. 65

Basionym. Denticula antarctica McCollum; Schrader, 1976, p. 631 , pl. 4, figs. 3, 22-23, and 25. (Plate 6, Fig. 22, Plate 7, Fig. 17, and Plate 9, Fig. 27)

Denticulopsis meridionalis Maruyama, in Harwood and Maruyama, sp. nov.

Synonyms. Denticula hustedtii var. ovata Schrader, 1976, p. 632, in part, pl. 4, figs. 12 and 14-15; Denticula hustedtii(?), Gombos, 1977 , pl. 8 , fig. 5 
Description. Valves are strongly silicified, elliptical with broadly rounded ends, 18-37 $\mu \mathrm{m}$ long, 7-10 $\mu \mathrm{m}$ wide. Approximately 3-4 primary pseudosepta per $10 \mu \mathrm{m}$ are present along the pervalvar axis. The secondary pseudosepta are $0-2$ in between the primary pseudosepta. Short marginal ribs are present between every pseudoseptae. Density of all pseudoseptae (primary and secondary) is 5 per $10 \mu \mathrm{m}$ along the pervalvar axis. The valve surface is finely punctate in decussate arrangement, transapical striae are $2-3$ in 10 ' $\mathrm{m}$ between pseudosepta. The valve lacks a deck and tsuzumis, which are siliceous processes that connect or couple the valve to the copula. The copula is heavily silicified and represents a sort of closed intercalary band; its outline is the same as the valve shape. Most specimens possess a relief-like ornamentation along the copula face edge. Cross bars are completely connected between both sides of the copula; their arrangement corresponds to the position of the primary pseudosepta. Several foramina are present, each bordered by cross bars, and they are lined up along the pervalvar axis on the copula surface. The foramina size, as well as shape, is generally irregular and various.

Holotype. Plate 7, Fig. 1, Sample 120-751A-9H-4, 105-106 cm. IGPS Collection No. G5-182 deposited in the Museum of Yamagata University.

Stratigraphic range: early late Miocene. The stratigraphic range of D. meridionalis is limited to the upper part of the Denticulopsis dimorpha Zone, and ends concurrently with the end of the acme of $D$. dimorpha.

Discussion. This variety differs from the typical $D$. hustedtii for lack of tsuzumis (Maruyama, 1984), which are siliceous processes on the deck whose function is to connect or couple with a copula. An isolated copula resembles that of $D$. dimorpha, but differs in the various sizes of central foramina; the absence of marginal thickenings around apex sides of both apical foramina; and the relatively weak silicification. Also, an isolated copula differs from that of $D$. hustedtii s.s. because the closed outline and cross bars are completely connected between both copula sides. This new species is closely related to Denticulopsis hustedtii because of the presence of the secondary pseudosepta and the irregular positioning of the cross bars in the copula. Because the deck is lost just below the valve, and the cross bars are firmly laid in copula, this taxon has also a close relationship with Denticulopsis dimorpha. The above morphologic characters and its restricted stratigraphic range indicate that this taxon is an interspecific hybrid between $D$. hustedtii and $D$. dimorpha, though there is no evidence concerning past fertility between them. This taxon has not yet been reported from the North Pacific and is interpreted accordingly as being endemic to the Southern Ocean.

Derivation of name. The name represents the province of occurrence, the Southern Ocean of the Southern Hemisphere. (Plate 6, Figs. 1-4; Plate 7, Figs. 1-4, 6-9, and 11-13; Plate 9, Figs. 1-4 and 10-14; and Plate 10, Fig. 7)

Denticula norwegica Schrader, in Schrader and Fenner, 1976, p. 978 , pl. 1, fig. 38; Akiba and Yanagisawa, 1986, p. 487, pl. 2, figs. 15-21, and pl. 6, figs. 1-9. (Plate 5, Fig. 10)

Denticulopsis praedimorpha Barron ex Akiba, 1982, p. 46, pl. 11, figs. 9-27; Barron, 1980, pl. 1, fig. 20; Akiba and Yanagisawa, 1986, p. 489 , pl. 13, figs. 1-28, and pl. 14, figs. 1-12. (Plate 6, Figs. 8-10, 12 , and 14-17)

\section{Denticulopsis cf. praedimorpha}

Remarks. In the copula, some of the cross bars are completely connected between both copula sides as in $D$. dimorpha, but the others remain disconnected as with $D$. praedimorpha. Morphostructure of copula is interpreted as an intermediate form within an evolutionary trend from ancestor $D$. praedimorpha toward descendant $D$. dimorpha, although morphologic characters of the other parts composing theca and frustule are not investigated in this paper. (Plate 6, Figs. 11 and 18-20)

Denticulopsis praelauta Akiba and Koizumi in Akiba and Yanagisawa, 1986, pl. 7, figs. 1-15, and pl. 8, figs. 1-9

Dicladia sp. resting spore of Chaetoceros lorenzianus Grunow. (Plate 18, Figs. 11 and 18-19)

Eucampia antarctica (Castracane) Mangin, 1914, p. 480, figs. 7-8; Mangin, 1915, pp. 58-66, figs. 41-44, and pl. 1, fig. 1; Syvertsen and Hasle, 1983; Fryxell et al., 1989
Synonym. Eucampia balaustium Castracane, 1886, pp. 97-99, pl. 18, figs. 5-6; Syvertsen and Hasle, 1983, pp. 181-187; Abbott, 1974, p. 313, pl. 10, figs. A-D; Fenner et al., 1976, p. 774, pl. 5, figs. 7-9; DeFelice and Wise, 1981, p. 62, pl. 5, figs. 7-9

Genus et species indet. 1 Gombos, 1983a, p. 571, pl. 7, figs. 1- 6 Genus et species indet. 1 (Plate 5, Fig. 13)

Genus et species indet. 2

Remarks. This fragment of a diatom may be the distal end of a Chaetoceros bristle. (Plate 2, Figs. 1-2)

Genus et species indet. 3

Remarks. This diatom may be related to the genus Kreagra Gersonde and Harwood (1990) because of the presence of a singlelayer wall with fine perforations as well as paired costae that fuse near the terminus of the valve into longitudinal costae that compose the terminal costate spine. Although most forms of Kreagra from the Lower Cretaceous are forked, one species, not yet described, is not forked and bears strong similarity to this diatom. (Plate 2, Figs. 3-5)

Hemiaulus caracteristicus Hajós 1976, pp. 828-829, pl. 15, fig. 10; Gombos and Ciesielski 1983, p. 602, pl. 20, figs. 1-5; Fenner 1985, p. 730 , fig. 9.14 4-6

Synonym. Hemiaulus "artifacts" Gombos 1977, p. 594, pl. 15, figs.

Hemiaulus incisus Hajós 1976, p. 829, pl. 23, figs. 4-9; Gombos and Ciesielski 1983, p. 602, pl. 20, fig. 6; Harwood 1988, p. 83, figs. 14.10 and 14.16

Synonyms. Hemiaulus kittonii Schmidt et al. 1874-1959, pl. 142, fig. 11 (in part); Hemiaulus sp. 1 of McCollum 1975, p. 535, pl. 9, fig. 2

Hemiaulus polycystinorum Ehrenberg 1854, pl. 36, figs. 43a-b; Grunow 1884, p. 65; Fenner, 1979, p. 521, pl. 21, figs. 13-14, pl. 22, figs. 4-5 and 7-10, and pl. 23, figs. 1-4; Harwood, 1986a, p. 86, pl. 3, fig. 11; Baldauf and Monjanel, in press, pl. 2, figs. 14-17

Hemiaulus recta var. twista Fenner 1984a, p. 332, pl. 2, fig. 6

Hemiaulus taurus Gombos in Gombos and Ciesielski, 1983, p. 606, pl. 19, figs. 1-8; Fenner, 1985, p. 733, fig. 11.15

Hemiaulus sp. A. (Plate 5, Fig. 11)

Hemidiscus cuneiformis Wallich, Hustedt, 1930, p. 904, fig. 542; Barron, 1985a, p. 786, figs. 9 and 13. (Plate 11, Fig. 11)

Hemidiscus karstenii Jousé; Ciesielski, 1983, p. 656

\section{Hemidiscus karstenï f. 1 Cies}

Hemidiscus ovalis (Gersonde) comb. nov.

Basionym. Actinocyclus ingens var. ovalis Gersonde, 1990, p. 792; Gersonde and Burckle, 1990, pl. 5, figs. 4-5; Baldauf and Barron, in press, pl. 5, fig. 1

Remarks. The cuneate form of this diatom in girdle view and the symmetry along the transverse axis in valve view suggests placement in the genus Hemidiscus rather than Actinocyclus. See additional comments above, under Actinocyclus ingens var. A. Compare with Hemidiscus forma 1 of Ciesielski, 1983. (Plate 11, Fig. 2, and Plate 12, Figs. 1-3)

Hemidiscus triangularus (Jousé, 1977) comb. nov.

Basionym. Cosmiodiscus insignis f. triangula Jousé, 1977, pl. 79, fig. 2; Ciesielski, 1983, p. 656, pl. 5, figs. 1-10; Ciesielski, 1986, pl. 4, figs. 5-6

Hemidiscus sp. 1 of Gersonde and Burckle, 1990, pl. 4, fig. 5. (Plate 12, Fig. 6)

Hemidiscus sp. 2 of Gersonde and Burckle, 1990, pl. 4, fig. 6. (Plate 12, Fig. 7)

Katahiraia aspera Komara, 1976, p. 385, text fig. 5, pl. 41, figs. 1-5

Kozloviella minor Jousé, 1974, p. 352, pl. 4, fig. 18; Gombos and Ciesielski, 1983, p. 602, pl. 22, fig. 1. (Plate 3, Figs. 10-11)

Lithodesmium reynoldsii Barron, 1976, p. 53, pl. 1, figs. 17-18; Barron, 1980, pl. 4, fig. 10; Barron, 1985a, p. 786, fig. 12.7 
Remarks. Lithodesmium minisculum (Grunow in Van Heurck, 1883, pl. 116, figs. 1-5; Ciesielski, 1983, pl. 6, figs. 3-4) is not distinguished from $L$. reynoldsii in this paper.

Lisitzinia ornata Jousé 1978, pp. 47-78, pl. 10, figs. 1-6; Gombos and Ciesielski, 1983, p. 602, pl. 18, figs. 1-4; Fenner, 1985, p. 734, fig. 10.11; Harwood, 1986b, p. 86, pl. 2, fig. 4

Synonym. Triceratium cruciforme Schmidt et al. 1874-1959, pl. 77, fig. 41; Schrader and Fenner, 1976, p. 1002, pl. 27, fig. 2

Remarks. Compare with Triceratium crux Brightwell 1859, p. 81, pl. 9, fig. 13. (Plate 4, Fig. 15)

Macrora stella Hanna, 1932, p. 196, pl. 12, fig. 7

Navicula udintsevii Schrader and Fenner, 1976, p. 991, pl. 23, fig. 33, and pl. 24, fig. 1(?)-2; Gombos and Ciesielski, 1983, pl. 21, fig. 8. (Plate 2, Fig. 12)

Navicula wisei sp. nov.

Description. Valve lanceolate with parallel sides in middle of valve; transverse striae ( 11 to 12 in $10 \mu \mathrm{m}$ ) composed of fine puncta (9 in $10 \mu \mathrm{m})$ at right angles to margin at valve edge and bending toward valve center as they approach the raphe; raphe positioned in depression along length of valve; central area and central nodule absent.

Remarks. Species not observed in SEM for detailed diagnosis.

Holotype. USNM Collection 458227 (Plate 17, Fig. 10)

Paratype. USNM Collection 458228 (Plate 17, Fig. 9)

Type level and locality. lower Pliocene, Sample 120-751A-4H-2, 105-106 cm, Kerguelen Plateau. (Plate 17, Figs. 9-10)

Neobrunia mirabilis (Brun); Hendey, 1981, p. 11, pl. 1, figs. 1-3, pl. 2 , figs. $4-7$, and pl. 3 , figs. $10-13$

Synonyms. Brightwellia mirabilis Brun, in Brun and Tempère, 1889 , p. 27 , pl. 8 , fig. 1 ; Kolbe, 1954 , p. 24 , pl. 4 , fig. 44 ; Bruniopsis mirabilis (Brun) Karsten; Schrader, 1976, p. 630, pl. 4, fig. 1; Ciesielski, 1983 , p. 655 , pl. 7 , figs. $1-2$

Nitzschia angulata (O'Meara) Hasle, 1972; Fenner et al., 1976, p. 775, pl. 1, figs. 17-39

Nitzschia arcula Gersonde, in press, pl. 2, fig. 4, pl. 4, fig. 4, and pl. 5, figs. 1-6; Gersonde and Burckle, 1990, pl. 1, figs. 25-26

Nitzschia aurica Gersonde, in press, pl. 1, figs. 8-25, pl. 3, fig. 5, pl. 4, figs. 5-6, and pl. 7, fig. 6; Gersonde and Burckle, 1990, pl. 2 , figs. 10-11. (Plate 17, Figs. 21-23)

Nitzschia barronii Gersonde, in press, pl. 3, fig. 6, pl. 4, figs. 1-3, and pl. 5, figs. 7-17; Gersonde and Burckle, 1990, pl. 1, figs. 11-13

Remarks. Many illustrations of this species are incorrectly referred to as Nitzschia antarctica Okuno (1954), in Desikachary et al. 1987. (Plate 17, Figs. 27-28)

Nitzschia clementia Gombos, 1977, p. 595, pl. 8, figs. 18-19; Gersonde and Burckle, 1990, pl. 2, figs. 22-23. (Plate 17, Fig. 18

Nitzschia curta (Van Heurck, 1909) Hasle, 1972, p. 115; Van Heurck, 1909 , p. 24 , pl. 3, fig. 37 ; Hustedt, 1958, pp. 160-161, pl. 11, figs 140-144, and pl. 12, fig. 159 ; Hasle, 1965 , p. 32 , pl. 6, fig. 6, pl. 12 , figs. $2-5$, pl. 13 , figs. $1-6$, pl. 16 , fig. 6 , and pl. 17 , fig. 5 ; Hargraves, 1968 , p. 56 , figs. $92-93$; Abbott, 1974 , p. 315 , pl. 7 , figs. A and D; Fenner et al., 1976, p. 775, pl. 4, figs. 5-10; Krebs, 1977 , p. 173 , pl. 8 , fig. 6 ; Akiba, 1982, p. 44 , pl. 10, figs. 1 and 2b. (Plate 17, Figs. 1-4)

Nitzschia denticuloides Schrader, 1976, p. 633, pl. 3, figs. 7-8, 10, 12 and 18-24. (Plate 8, Figs. 5-8 and 17, Plate 9, Figs. 24-26, and Plate 10, Fig. 1)

Nitzschia donahuensis Schrader, 1976, p. 633, pl. 2, fig. 30

Nitzschia efferans Schrader, 1976, p. 633, pl. 2, figs. 1, 3, and 5-7

Nitzschia evenescens Schrader, 1976, p. 633, pl. 2, figs. 22-23; Schrader and Fenner, 1976, p. 991, pl. 1, figs. 28-29. (Plate 4, Fig. 19)

Nitzschia fossilis (Frenguelli) Kanaya, in Kanaya and Koizumi, 1970; Schrader, 1973a, p. 707, pl. 4, figs. 9-11 and 24-25
Nitzschia grossepunctata Schrader, 1976, p. 633, pl. 3, figs. 1-4. (Plate 10, Fig. 2)

Nitzschia heteropolica Schrader, 1973a, pl. 26, figs. 1-2

Nitzschia interfrigidaria McCollum, 1975, p. 535, pl. 9, figs. 7-9; Schrader, 1976, p. 634; Gombos, 1977, p. 595, pl. 7, fig. 3; emended by Ciesielski, 1983, p. 655 , pl. 1, figs. 11-18

Nitzschia kerguelensis (O'Meara) Hasle, 1972, p. 115; Hasle, 1965, p. 14 , pl. 3, figs. 4-5, pl. 4, figs. 11-18, pl. 5, figs. 1-11, pl. 6, figs. $2-4$, pl. 7, fig. 9, pl. 8, fig. 10; and pl. 16, figs. 3-5; Abbott, 1974, p. 315 , pl. 8 , figs. G-H; Fenner et al., 1976, p. 776, pl. 2, figs. 19-30; Gombos, 1977, pl. 8, figs. 13-14; Akiba, 1982, p. 44, pl. 9, figs. 1a-4b; Desikachary et al., 1987, pl. 171-172

Nitzschia lacrima Gersonde, in press, pl. 1, figs. 1-6, 26, and pl. 2, figs. 1-3; Gersonde and Burckle, 1990, pl. 1, figs. 14-15

Nitzschia maleinterpretaria Schrader, 1976, p. 634, pl. 2, figs. 9, 11-19, 21, and 24. (Plate 6, Fig. 21)

Nitzschia marina Grunow, in Cleve and Grunow, 1880, p. 70; Schrader, 1973a, pl. 4, figs. 17-19

Nitzschia miocenica Burckle, 1972; Schrader, 1974, pl. 5, figs. 10-11; Barron, 1985a, pl. 13, fig. 5; Akiba and Yanagisawa, 1986, p. 469, pl. 39 , figs. 7-15, and pl. 41, figs. 1-2

Nitzschia panduriformis Gregory, 1857; Fenner, 1979, p. 525, pl. 32, figs. $27-29$

Nitzschia praecurta Gersonde, in press, pl. 1, figs. 7-17, pl. 2, figs. 5-6, pl. 3, figs. 3-4, and pl. 10, figs. 7; Gersonde and Burckle, 1990, pl. 1, figs. 21-24. (Plate 17, Figs. 25-26)

Nitzschia praeinterfrigidaria McCollum, 1975, p. 535, pl. 10, fig. 1; Schrader, 1976, p. 634; Gombos, 1977, p. 595, pl. 7, fig. 3; emended by Ciesielski, 1983, p. 655 , pl. 2, figs. 1-8 and 13-16, and pl. 3, fig. 5

Nitzschia pseudokerguelensis Schrader, 1976, p. 634, pl. 15, figs. $13-15$

Nitzschia reinholdii Kanaya ex Barron and Baldauf, 1986; Schrader, 1973b, p. 708, pl. 4, figs. 12-16, and pl. 5, figs. 1-9; Akiba and Yanagisawa, 1986, p. 496, pl. 40, figs. 8-9, and pl. 41, figs. 3-4

Nitzschia ritscherii (Hustedt) Hasle, 1972, p. 115; Hasle, 1965, pp. $20-21$, pl. 1, fig. 20 , pl. 4 , figs. $1-7$, and pl. 7, fig. 8; Hargraves, 1968 , p. 60 , figs. 103-104; Fenner et al. 1976, p. 777 , pl. 3, figs. 1-12; Akiba, 1982, pl. 9, figs. 5-10

Nitzschia separanda (Hustedt) Hasle, 1972; Fenner et al., 1976, p. 777 , pl. 1, figs. 1-16, and pl. 2, figs. 23-29

Nitzschia weaveri Ciesielski, 1983, p. 655 , pl. 1, figs. 1-10

Nitzschia sp. 17 of Schrader, 1976, p. 634, pl. 3, figs. 13-15 and 17, and pl. 2, fig. 10; Harwood et al., 1989, p. 108, pl. III, figs. 6-10. (Plate 7, Fig. 16)

Nitzschia sp. A Harwood et al., 1989b, p. 105, pl. 3, figs. 12-13

Synonyms. Nitzschia truncata Brady, 1979, 1980; N. curta sensu Kellogg and Kellogg, 1986, pl. 2 (not fig. 23). (Plate 5, Fig. 16)

Paralia architecturalis (Brun); Fenner, 1985, p. 734, figs. 12.4-12.5 . Basionym. Melosira architecturalis Brun in Schmidt et al., 1892, pl. 177, figs. 49-50; Gombos, 1983a, p. 570; Fenner, 1985, p. 734, figs. 12.4-12.5; Gombos and Ciesielski, 1983, p. 602; Barron et al., 1984, pl. 7, figs. 1-3

Paralia sulcata (Ehrenberg) Cleve; Hustedt, 1930, p. 276, figs. 118-120.

Basionym. Melosira sulcata (Ehrenberg) Kutzing.

Paralia sulcata var. crenulata Grunow, 1884, p. 94, pl. 5, fig. 34; Hustedt, 1930, p. 278; Strelnikova, 1974, p. 49, pl. 1, figs. 7-8. (Plate 1, Figs. 9-11)

Porosira sp. A. (Plate 16, Fig. 11)

Praecymatosira monomembranacea (Schrader) Strelnikova, in Jousé et al., 1979, p. 64, figs. 169-176; Gombos, 1983, p. 570, pl. 4, figs. $12-13$ 
Basionym. Pseudorutilaria monomembranacea Schrader in Schrader and Fenner, 1976, p. 994, pl. 22, figs. 1-6

Proboscia alata group (Prishtmell) Sündstrom, 1986

Synonym. Rhizosolenia alata group Brightwell, 1858; Fenner et al., 1976, p. 778, pl. 13, fig. 2; Akiba, 1982, pl. 7. (Plate 18, Figs. 15 and 17)

Pseudopyxilla baltica(?) (Grunow) Forti, 1909; Schrader and Fenner, 1976, pl. 44, figs. 13-14. (Plate 2, Figs. 9-10)

Pseudopodosira bella Glezer and Posnova; Fenner, 1979, pl. 10, figs. 2-3 and 6-8

Pseudorocella barbadense Deflandre; Fenner, 1979, pl. 23, figs. 13-16, and pl. 22, figs. 1-3

Pseudotriceratium radiosoreticulatum Grunow, in Van Heurck 1883, pl. 112, fig. 5; Jousé 1977, pl. 15, fig. 7; Gombos and Ciesielski 1983 , p. 603 , pl. 17, figs. 1-3; Fenner 1985 , p. 735 , fig. 12.11 ; Harwood, 1986b, pl. 2, fig. 12; Harwood, 1989, p. 80, pl. 3, figs. $14-15$

Synonyms. Triceratium coscinoides Grove and Sturt 1887, p. 327 , pl. 19, fig. 13; McCollum, 1975, p. 536, pl. 14, figs. 6-7; Pseudotriceratium aff. cheneveri in Schrader and Fenner, 1976, p. 994, pl. 26, figs. 6 and $8-9$, and pl. 27, figs. 4 and 13; Pseudotriceratium cheneveri in Harwood 1986a, p. 86, pl. 2, fig. 8

Pterotheca reticulata Sheshukova-Poretzkaya 1967, p. 229, pl. 36, figs. 6a-c, and pl. 8, figs. 4a-c; Schrader and Fenner, 1976, p. 994, pl. 12 , figs. $1-2$ and 11 , pl. 38 , figs. $10-12$ and 14 , and pl. 45 , fig. 6 ; Harwood 1986 a, p. 86 , pl. 6, figs. $20-23$

Pterotheca sp. cf. with Pterotheca sp. (simplex) Schrader and Fenner, 1976, pl. 43, figs. 4-8. (Plate 2, Fig. 7)

Pyxilla reticulata group Grove and Sturt, 1887, p. 145, pl. 13, fig. 50; Gombos and Ciesielski, 1983, p. 603; Fenner, 1985, p. 735, figs. 11.6-11.10.

Raphidodiscus marylandicus Christian, 1887; Andrews, 1973, p. 232, pls. 1-5; Schrader, 1976, p. 635, pl. 5, fig. 19, and pl. 15, fig. 16

Rhizosolenia antarctica Fenner, 1984a, pl. 2, fig. 3; Fenner, 1985, p. 736 , figs. 11-12

Rhizosolenia costata Gersonde, in press, pl. 9, figs. 1-6, and pl. 10, figs. 1-6; Gersonde and Burckle, 1990, pl. 3, fig. 6. (Plate 18, Figs. 1-2)

\section{Rhizosolenia costata var. A}

Discussion. this variety differs from the type by the presence of a bluntly rounded, heavily silicified spine, in contrast to the pointed, tapering spine in Gersonde's species. (Plate 18, Figs. 3-4)

Rhizosolenia hebetata group Bailey, 1856, p. 5, pl. 1, figs. 18-19. (Plate 11, Fig. 7)

Rhizosolenia oligocaenica Schrader, 1976, p. 635, pl. 9, fig. 7; Harwood, 1989, p. 80

Synonym. Rhizosolenia gravida Gombos and Ciesielski, 1983, pl. 11, figs. 1-7; Rhizosolenia sp. A of Gombos, 1977a, pl. 23, fig. 6. Fenner (1985) suggests that early forms of $R$. gravida at Site 511 are the same as $R$. oligocaenica, and thus places $R$. gravida as a junior synonym. (Plate 3, Fig. 5)

Rhizosolenia styliformis Brightwell, 1858; Hustedt, 1930, pp. $584-$ 588, figs. 333-335; Schrader, 1973b, p. 710, pl. 10, figs. 1 and 18-21; Abbott, 1974, p. 318, pl. 11, fig. 8; Fenner et al., 1976, p. 779, pl. 13, figs. 3-5 and 9; Akiba, 1982, p. 44, pl. 7, figs. 3-4. (Plate 18, Fig. 20)

Rhizosolenia sp. A of Harwood, 1989, pl. 3, fig. 19. (Plate 18, Fig. 16) Rhizosolenia sp. A. (Plate 2, Fig. 8)

Rhizosolenia sp. B. (Plate 18, Figs. 13-14)

Rhizosolenia sp. C. (Plate 18, Figs. 5-6)

Rhizosolenia sp. D

Synonym. Rhizosolenia sp. A of Akiba, 1986, pl. 18, fig. 11; Rhizosolenia sp. A of Koizumi, 1968, pl. 34, figs. 22a-b. Note the structure of endospores associated with Rhizosolenia styliformis in Van Heurck, 1909, pl. 4, figs. 67, 71, and 75. (Plate 18, Figs. 7-10)

Rocella gelida (Mann) Bukry, 1978, p. 788, pl. 5, figs. 1-13; Gombos and Ciesielski, 1983 , p. 604 , pl. 6 , figs. 1-6, and pl. 26, fig. 1

Rocella gelida var. schraderi (Bukry) Barron, 1983, pl. 4, fig. 10

Basionym. Rocella schraderi Bukry, 1978, p. 788, pl. 6, figs. 1-10, and pl. 7, fig. 1; Gombos and Ciesielski, 1983, pl. 22, fig. 6

Rocella semigelida(?) Gombos, 1983b, pp. 796-799, pl. 2, figs. 1-12. (Plate 4, Figs. 6-7)

Rocella praenitida (Fenner) Fenner, in Kim and Barron 1986, p. 177, pl. 4 , fig. 3 .

Basionym. Coscinodiscus praenitidus Fenner, in Schrader and Fenner 1976, p. 972, pl. 14, figs. 7-9 and 12, pl. 27, fig. 8, pl. 35, fig. 24, and pl. 36, fig. 5. (Plate 4, Figs. 1-3 and 5)

Rocella praenitida? variant.

Remarks. Compare this relatively flat diatom with the convex Genus et species indet. (9) of Schrader and Fenner, 1976, pl. 36, fig. 6a-b. (Plate 4, Fig. 4)

Rocella vigilans Fenner, 1984a, p. 333, pl. 1, fig. 11; Gombos and Ciesielski, 1983, p. 604, pl. 6, figs. 7-10, and pl. 26, fig. 2; Fenner, 1985 , p. 737 , figs. $7-14$ and $7-15$

Basionym. Coscinodiscus vigilans Schmidt, sensu Kolbe, 1954, p. 36 , figs. 13,14 , but not $C$. vigilans Schmidt, 1888 , pl. 114, fig. 11

Remarks. Two forms of Rocella vigilans are included here. The two varieties are morphologically distinct and stratigraphically distinct, at least on Kerguelen Plateau. The older (var. A) appears to be transitional from $R$. praenitida, with smaller valve diameter and finer structure on the valve face (Plate 4, Figs. 8-12) than the larger, more robust forms (B) that occur higher in the section (Plate 4, Figs. 13-14). The younger and larger forms (B) also exhibit a greater degree of sculpturing of the valve face. A distinct stratigraphic gap separates these two varieties. This gap may be a "biogeographic gap" at Kerguelen Plateau, with a continuous transition between these forms evident in more southerly sites, i.e. the gap interval represents a time when all Rocella vigilans migrated southward. The reappearance of the larger variety (var. B) reflects normal evolutionary drift within $R$. vigilans, which appears as an evolutionary "event" because of the punctuated range.

Rocella vigilans small form (var. A)

Remarks. This diatom differs from Rocella vigilans s.s. (var. B) in its smaller size, finer structure, lack of sculpturing on the valve face, and slightly lower stratigraphic range that does not overlap with $R$. vigilans s.s. This diatom appears transitional between Rocella praenitida and Rocella vigilans s.s., and bears a strong resemblance to the plicate Rocella princeps Jousé. We expect that further stratigraphic studies noting the different stratigraphic ranges of $R$. vigilans and this diatom will result in the erection of a new taxon.

Synonym. Coscinodiscus vigilans Schrader and Fenner, 1976, pl. 14, fig. 6. (Plate 4, Figs. 8-12)

Rossiella paleacea (Grunow) Desikachary and Maheshwari; Barron, 1985a, pl. 9, fig. 6

Basionym. Cussia paleacea (Grunow) Schrader

Rossiella symmetrica Fenner; Fenner, 1985, p. 737, figs. 7.5-7.7

Synonyms. Bogorovia veniamini Jousé, sensu Gombos, 1977, p. 593; Rossiella sp. Gombos and Ciesielski, 1983, pl. 24, figs. 1-2

Rouxia antarctica Heiden, in Heiden and Kolbe, 1928, p. 632, pl. 4, fig. 90; Abbott, 1974, p. 318, pl. 9, fig. G; McCollum, 1975, p. 535, pl. 12 , fig. 3 ; Schrader, 1976 , p. 635 , pl. 5 , figs. 1-8; Gombos, 1977 , p. 596, pl. 7, fig. 12; Ciesielski, 1983, p. 656; Kellogg and Kellogg, 1986, p. 86. (Plate 17, Fig. 24)

Rouxia diploneides Schrader, 1973a, p. 710, pl. 3, fig. 27-32; McCollum, 1975, p. 535, pl. 11, figs. 11-12; Macchiavello and Lange, 1980 , p. 5, pl. 4, fig. 18. (Plate 17, Fig. 12)

Rouxia granda Schrader, in Schrader and Fenner 1976, p. 997, pl. 7, fig. 17; Gombos and Ciesielski 1983, p. 604, pl. 21, fig. 11 
Rouxia hannae Jousé, 1974, p. 349, pl. 2, fig. 13; Gombos and Ciesielski, 1983, p. 604 , pl. 21, fig. 13

Rouxia heteropolara Gombos, 1974, p. 275, fig. 1; Gombos, 1977a, p. 597, pl. 7, figs. 14-15; Gersonde and Burckle, 1990, pl. 5, fig. 2

Rouxia heteropolara var. A

Synonyms. Rouxia oligocaenica Schrader, sensu Akiba, 1982, p. 45; not Rouxia oligocaenica Schrader, 1976, p. 636, of a specimen illustrated in McCollum, 1975 (pl. 12, fig. 1) as R. peragalli (according to Akiba, 1982, p. 45); Rouxia sp. 2 of Ciesielski, 1983, pl. 2, figs. 21-22

Remarks. At the present time, this variety may include several distinct taxa that were lumped here. The key criteria for grouping them was the different form of the hyaline areas at the poles: triangular at one end and rounded at the other. This taxon is highly variable in length, as shown in Plate 17. Ciesielski (1983) comments on the isopolarity of the species he illustrates, although the different shape of the hyaline areas at each pole (triangle vs. half-circle) is clearly visible in his specimens.

Discussion. This species is similar to Rouxia heteropolara Gombos but differs by the shorter valve length and lower stratigraphic range. The range of these two species overlaps only slightly, and it is probable that this variety is ancestral to $R$. heteropolara. (Plate 17, Figs. 14-17)

Rouxia isopolica Schrader, 1976, p. 635, pl. 5, figs. 9, 14-15, and 20; Akiba, 1982 , p. 45 , pl. 8 , figs. 1-7

Synonym. Rouxia peragalli in Abbott, 1974, p. 318, pl. 9, figs. A-C. (Plate 17, Fig. 13)

Rouxia naviculoides Schrader, 1973a, p. 710, pl. 3, figs. 27-32

Rouxia obesa Schrader in Schrader and Fenner, 1976, p. 997, pl. 24, figs. 5-6; Gombos and Ciesielski, 1983, p. 604, pl. 21, fig. 12

Rouxia sp. A. (Plate 17, Fig. 11)

Rutilariopsis sp. 1 of Fenner, 1979

Sceptroneis grunowii Anissimova, 1937; Schrader and Fenner, 1976, pl. 22, figs. 26-28, pl. 23, fig. 8, and pl. 25 , figs. 7 and 9

Sceptroneis lingulatus Fenner, 1979, p. 531, pl. 31, figs. 8-10; Gombos and Ciesielski 1983, p. 604, pl. 24, fig. 8; Harwood, 1989, p. 89 , pl. 6 , fig. 11

Synonym. Genus et species indet. (C) of Gombos 1977, p. 599, pl. 12, fig. 8

Sceptroneis mayenica Fenner, in Schrader and Fenner, 1976, pl. 22, figs. $22-25$, pl. 23 , figs. $1-4$, and pl. 25 , figs. 6 and 8

Sceptroneis pesplanus Fenner and Schrader, in Schrader and Fenner, 1976, p. 998, pl. 22, figs. 30-31; Fenner, 1985, p. 738, fig. 9.9; Gombos and Ciesielski, 1983, p. 604, pl. 21, fig. 10

Sceptroneis tenue Schrader and Fenner, 1976, p. 999, pl. 3, figs. 1-4, pl. 29 , figs. 14-16(?), and pl. 25 , figs. 12,22 , and 24

Simonseniella barboi (Brun) Fenner, in press.

Basionym. Rhizosolenia barboi (Brun, 1894) Tempère and Peragallo; Schrader, 1976, p. 635, pl. 9, figs. 11-13; Akiba and Yanagisawa, 1986 , p. 497 , pl. 42 , figs. $3-5,7$, and $10-11$

Discussion. If the genus Proboscia of Sündstrom (1986) is validly published in a $\mathrm{Ph} . \mathrm{D}$. dissertation, then this name will have priority over Simonseniella. (Plate 11, Fig. 13)

Simonseniella praebarboi (Schrader) Fenner, in press

Basionyms. Rhizosolenia praebarboi Schrader, 1973a, pp. 709710, pl. 24, figs. 1-3; Gombos and Ciesielski, 1983, p. 604, pl. 24, fig. 10; Akiba and Yanagisawa, 1986, p. 497, pl. 42, figs. 8-9, and pl. 43, figs. 1-9

Remarks. Rhizosolenia interposita Hajós (1976) is included within this taxon at this time in this report. If the genus Proboscia of Sündstrom (1986) is validly published in a Ph.D. dissertation, then this name will have priority over Simonseniella.

Skeletonema barbadense Greville, 1865, p. 43, pl. 5, fig. 1; Gombos and Ciesielski, 1983 , p. 605 , pl. 5 , figs. $1-4$, and pl. 21 , fig. 4

Sphynctolethus pacificus (Hajós) Sims 1986, pp. 250-252, figs. 29-34
Basionym. Cerataulus pacificus Hajós 1976, p. 828, pl. 22, figs. 1-6 Synonym. Hemiaulus pacificus (Hajos) Gombos and Ciesielski 1983 , p. 602 , pl. 8 , figs. 1-3; Fenner, 1985, p. 732 , fig. 12.7

Stellarima spp. Hasle and Sims, 1986

Stephanopyxis corona (Ehrenberg) Grunow in Van Heurck 1883, p. 90, pl. 83ter, figs. 10-11; Schmidt et al., 1874-1959, pl. 130, figs. $16-17$ and 36

fig. 5

Synonym. Stephanopyxis sp. B of Harwood, 1986b, p. 87, pl. 4,

Stephanopyxis grunowii Grove and Sturt, in Schmidt et al., 18741959, pl. 130 , figs. $1-4$ and 6 ; Hanna, 1927 , p. 33 , pl. 4 , fig. 2 ; Hajos, 1976, pl. 4, figs. 1-2; Gombos 1977, p. 597, pl. 28, figs. 3-5, pl. 31, figs. 1-2 and 7, and pl. 32, figs. 1-3; Harwood, 1989, pl. 2, figs. 5-6

Stephanopyxis ornata Schulz, 1935, p. 397, pl. 2, figs. 4-6; Fenner, 1985 , p. 738, fig. 14.7. (Plate 2, Fig. 6)

Stephanopyxis spinosissima Grunow, 1884, pp. 90-91; Grunow in Schmidt et al., 1874-1959, pl. 123, fig. 18; Hanna, 1927, p. 130; Schrader and Fenner, 1976, p. 1000, pl. 31, fig. 5

Synonym. Stephanopyxis sp. A of Harwood, 1986b, p. 87, pl. 4, fig. 2

Stephanopyxis splendidus (Greville) Harwood, 1989, pl. 2, figs. 1-4

Basionym. Coscinodiscus splendidus Greville, 1865, p. 44, pl. 5, fig. 3; Schmidt et al., 1874-1959, pl. 65, fig. 11; see discussion of this species in the comments on Stephanopyxis superba in Gombos, 1977, p. 597

Synonyms. Thalassiosira hydra Gombos, in Gombos and Ciesielski, 1983, pl. 7, figs. 1-6; Stephanopyxis permarginata Grove, in Tempère, 1890, p. 32, pl. 5, figs. 4-5; Thalassiosira hydra Gombos, in Gombos and Ciesielski, 1983, p. 606, pl. 7, figs. 1-6 (for resting spores of $S$. splendidus, see Harwood, 1989)

Stephanopyxis turris group (Greville and Arnott) Ralfs, in Pritchard, 1861; Schrader and Fenner, 1976, pl. 30, figs. 1-10 and 14, and pl. 37, figs. 17-19

Synedra sp. 1 and Synedra sp. 2 of Brady, 1979, pl. 6, fig. 6; Harwood et al., 1989b, pl. 3, figs. 21-22; Nitzschia(?) sp. A. of Harwood, 1986a, pl. 18 , fig. 10 , and pl. 21 , figs. $6-8$

Discussion. It is unclear if this diatom belongs in Synedra. (Plate 17, Figs. 5-8)

Synedra jouseana Sheshukova-Poretzkaya, 1962, p. 208, fig. 4; Gombos 1977 , p. 599 , pl. 12, figs. 5-7; Schrader, 1973b, p. 710, pl. 23 , figs. 21-23, 25, and 38. Synedra miocenica Schrader is tabulated under this taxon in this paper. (Plate 11, Figs. 8-9)

Thalassionema nitzschioides (Grunow, in Van Heurck); Fenner et al., 1976, pl. 14, fig. 11

Thalassionema nitzschioides var. parva Heiden, in Heiden and Kolbe, 1928, p. 564, fig. 118; Fenner et al., 1976, pl. 14, fig. 10

Thalassionema schraderi Akiba, 1982, p. 50, pl. 1, figs. 6-11 and 16-18

Synonym. Thalassionema hirosakiensis (Kanaya) Schrader, 1973b, pl. 23, figs. 31-33; Barron, 1980, pl. 2, fig. 6; Barron, 1981, pl. 5, fig. 4; Thalassionema hirosakiensis (Kanaya) Schrader s.l., Akiba et al., 1982, pl. 3, figs. 77-80

Thalassiosira antarctica Comber; Johansen and Fryxell, 1985, p. 158, figs. $15-17$ and $37-39$

Thalassiosira antiqua (Grunow); Koizumi, 1973, p. 834, pl. 7, fig. 12; Schrader, 1973a, pl. 11, fig. 25, and pl. 25, fig. 19; Barron, 1980, pl. 5, fig. 5; Akiba and Yanagisawa, 1986, p. 498, pl. 51, figs. 1-2 and 4 , and pl. 52, figs. 1-9

Thalassiosira bukryi(?) Barron, 1983, p. 511, pl. IV, figs. 1-2, and pl. VI, fig. 9

Discussion. This species is similar to Barron's taxon from the upper Oligocene and lower Miocene of the equatorial Pacific. In Leg 120 materials, this diatom is apparently restricted to the lower Oligocene. 
The different stratigraphic range is the basis for the questionable identification of Barron's species T. bukry.

Remarks. Coscinodiscus pulchellus Greville, 1866, p. 3, pl. 1, fig. 7; Rattray, 1890, p. 469 (21). Also compare with Coscinodiscus (Thalassiosira) obscurus var. minor Schmidt sensu Jousé, 1978, pl. 61, figs. 14-15; and Coscinodiscus argus var. 1 in Barron, Bukry and Poore, 1984, pl. 7, fig. 10. (Plate 2, Figs. 13-16)

Thalassiosira complicata Gersonde, in press, pl. 3, figs. 1-2, pl. 5, figs. $18-20$, pl. 6 , figs. 1-6, and pl. 7, figs. 1-5; Gersonde and Burckle, 1990, pl. 4, figs. 1-2

Discussion. This diatom is also illustrated in Brady, 1979, pl. 10, figs. 12-13; Harwood, 1986a, pl. 17, figs. 15-18; Desikachary, et al., 1987, pl. 213, figs. 1-5, but under different names. (Plate 14, Figs. 18-21)

Thalassiosira convexa var. aspinosa Schrader, 1974, p. 916, pl. 2, figs. 8-9 and 13-21; Barron, 1985a, pl. 11, figs. 8 and 12

Thalassiosira eccentrica group (Ehrenberg) Cleve; Hustedt, 1930, p. 388, fig. 201, as Coscinodiscus excentricus; Fenner et al., 1976, pl. 10, figs. 1-2 and 4-5; Fryxell and Hasle, 1972, p. 300, figs. 1-18

Thalassiosira elliptipora (Donahue, 1970) Fenner, in press

Basionym. Coscinodiscus elliptiporus Donahue, 1970, p. 210, pl. 4, figs. e and i-m; Abbott, 1974, p. 311, pl. 4, figs. A-D; McCollum, 1975 , p. 526 , pl. 16 , fig. 10 ; Gombos, 1977 , p. 592 , pl. 3 , figs. $1-3$ and 6, and pl. 9, fig. 3; Macchiavello and Lange, 1980, p. 5, pl. 2, figs. 1-2; Barron, 1985b, pl. 6, figs. 17 and 21; Ciesielski, 1986, pl. 1, fig. 6; Harwood, 1986a, pl. 15, figs. 16-17, and pl. 19, figs. 14-15; Desikachary et al., 1987 , pls. $108-110$.

Remarks. The diatom species Coscinodiscus planisculus Rattray, 1890 , p. 42 , pl. 1 , fig. 22 , may have priority over Donahue's name $C$. elliptipora, but the incomplete and poor illustration of Rattray's specimen may argue for retaining the newer name. Subsequent documentation of Rattray's holotype, if available, however would require the use of this name as Thalassiosira planisculus (Rattray) $\mathrm{n}$. comb. We also question whether Donahue's species is validly published. (Plate 16, Fig. 12)

Thalassiosira fasciculata sp. nov.

Synonym. Coscinodiscus bullatus Janisch sensu Hustedt, 1958, p. 112, pl. 4, figs. 26-28; Kozlova, 1966, pl. 4, fig. 2; Hargraves, 1968, p. 40, fig. 62; Jousé et al., 1977, pl. 71, figs. 12 and 16, pl. 74, fig. 12, and pl. 76, figs. 7-8 and 11; Harwood, 1986a, pl. 16, figs. 12-14, and pl. 27, figs. 7-8.

Not C. bullatus sensu Janisch, 1888, or sensu McCollum, 1975, p. 526, pl. 16, fig. 1; Fenner et al., 1976, p. 772, pl. 6, figs. 11-14; Akiba, 1982 , p. 42 , pl. 4 , figs. $7 \mathrm{a}-\mathrm{b}$.

Description. Valve circular, slightly convex; areola arranged in radial rows, strongly fasciculate, with areolar rows parallel to the longest row in the center of the fascicle; areolae of even size (7-8 in $10 \mu \mathrm{m}$ ) across most of the valve, decreasing in size at the valve mantle to nearly $1 / 2$ normal size; strutted processes (usually more than 20 ) scattered over valve face, one usually present near middle of longest row of areolae; margin hyaline, narrow, bearing regularly spaced "marks" (processes? not seen in SEM) 2 in $10 \mu \mathrm{m}$ around the margin.

Remarks. Janisch's species $C$. bullatus, which bears numerous elongate pores at the margin, is named $T$. striata $\mathrm{n}$. sp. in this paper. We refer to the diatom $C$. bullatus illustrated by Hustedt (1958, pl. 4) within our new species $T$. fasciculata. Small specimens of $T$. fasciculata could be confused with $T$. vulnifica, which we distinguish by the lower number of more prominent processes on the valve face that are clearly visible in all focal planes, and the generally smaller size. The finer areolation and closer packing of areolae in $T$. fasciculata is also useful.

Holotype. USNM Collection 458229 (Plate 15, Fig. 5)

Paratype. USNM Collection 458230 (Plate 15, Fig. 6)

Type level and locality. mid-Pliocene, Sample 120-751A-2H-3, 105-106 cm, Kerguelen Plateau. (Plate 15, Figs. 4-6)

Thalassiosira fraga Schrader, in Schrader and Fenner, 1976, p. 1001, pl. 16, figs. 9-12; Barron, 1985b, pl. 5, fig. 2; Harwood et al., 1989b, pl. 3, figs 2-3; Gersonde, 1990, p. 793.

Remarks. Akiba and Yanagisawa, 1986, p. 498, pl. 51, figs. 5-10, and pl. 53, figs. $1-8$, illustrate a different form of this diatom from lower latitudes; further study of this group is warranted. (Plate 11, Fig. 10)

Thalassiosira gracilis (Karsten) Hustedt, 1958, p. 109, pl. 1, figs. 4-7; Abbott, 1974, p. 320, pl. 6, figs. C-D; Fenner et al., 1976, p. 780, pl. 9, figs. 12-20; Krebs, 1977 , p. 182 , pl. 12 , fig. 8

Remarks. Many workers have used the name $T$. gracilis for the Pliocene diatom $T$. inura.

Thalassiosira insigna (Jousé) new comb.

Basionym. Cosmiodiscus insignis Jousé, 1959, pl. 4, fig. 9; Jousé, 1961 , p. 67, pl. 2, fig. 8; Jousé, et al., 1963, pl. 2, fig. 29; SheshukovaPoretzkaya, 1967, p. 175, pl. 25, figs. 2a-c; Donahue, 1967, pl. 1, figs. e-f; Koizumi, 1973, pl. 4, figs. 7-11; Abbott, 1974, p. 313, pl. 6, fig. F; McCollum, 1975, p. 527, pl. 8, fig. 5; Gombos, 1977, p. 593, pl. 4, figs. 4-5; Ciesielski, 1986, pl. 1, figs. 1-5

Remarks. This species is transferred to the Genus Thalassiosira because of its great similarity to $T$. inura and transitional forms between these species. It is not clear whether some diatoms attributed to Greville's genus Cosmiodiscus belong there or in Thalassiosira, nor whether the North Pacific species of $C$. insignis is the same as the Antarctic species. Most forms of $T$. insigna bear a central structure (dimple or bubble), which is not a process (Gersonde, 1990), similar to $T$. inura, that is often enlarged through dissolution. Several forms appear to be transitional between $T$. inura and $T$. insigna (Plate 14). Another Antarctic species previously attributed to Cosmiodiscus is transferred below to Thalassiosira and named $T$. oliverana var. sparsa n. sp. (Plate 14, Figs. 3-5)

Thalassiosira insigna/inura transitional forms. (Plate 14, Figs. 7-10 and 16)

Thalassiosira inura Gersonde, in press, pl. 6, figs. 7-14, and pl. 8, figs. 1-6; Gersonde and Burckle, 1990, pl. 3, figs. 15-17, and pl. 5, fig. 14

Synonyms. Cestodiscus(?) sp. of Gombos, 1977, pl. 5, fig. 8; Thalassiosira gracilis in Jousé et al., 1963, pl. 1, fig. 2; Brady, 1979, pl. 3, figs. 7-8; McCollum, 1975, pl. 14, fig. 3; Thalassiosira umbonatus (Castracane) Harwood, 1986a, pl. 15, figs. 1-4, and pl. 17, fig. 14;

T. jacksonii sensu Harwood, 1986a, pl. 15, figs. 6-7

Remarks. The lowest occurrence of this diatom is used as a zonal species by Gersonde and Burckle (1990) in the lower Pliocene. This datum may be diachronous, having an earlier appearance on the Antarctic shelf in the uppermost Miocene (Harwood, 1986a, DVDP-11 drillhole), but more likely, these Miocene forms are $T$. jacksonii and not $T$. inura (J. Barron, pers. comm., 1990). One such form from the upper Miocene is illustrated in Plate 5, Figure 14, but these occur in low abundance. Perhaps the zonal datum for the base of the $T$. inura Zone should be defined at the first abundant appearance as we suggest in the 120 zonal scheme. (Plate 14, Figs. 12-16, and Plate 5, Fig. 14)

Thalassiosira jacksonii Koizumi and Barron, in Koizumi, 1980, p. 396, pl. 1, figs. 11-14; Barron, 1980, pl. 6, figs. 2, 6, and 10?; Akiba, 1986, p. 446 , pl. 11, fig. 2

Synonym. Coscinodiscus minimus Karsten var. in Mann, 1937, p. 43 , pl. 4 , fig. 6

Thalassiosira kolbei (Jousé, 1962) Gersonde, 1990, p. 793; Gersonde and Burckle, 1990, pl. 3, fig. 1

Basionym. Coscinodiscus kolbei (Jousé), pl. 2, fig. 4; Donahue, 1970 , p. 202, pl. 5 , figs. A-C; McCollum, 1975 , p. 527, pl. 4, figs. 7-9; Barron, 1985b, pl. 6, fig. 15

Thalassiosira lentiginosa (Janisch) Fryxell, 1977

Basionym. Coscinodiscus lentiginosus Janisch, 1878 in Schmidt et al., 1874-1959, pl. 58, fig. 11; Hustedt, 1958, p. 116, pl. 4, figs. 22-25; Abbott, 1974, p. 312, pl. 3, figs. D-F; Fenner et al., 1976, p. 773, pl. 7, figs. 4-6; DeFelice and Wise, 1981, p. 61, pl. 1, figs. 4-5; Akiba, 1982, p. 42, pl. 2, figs. 1-5. (Plate 19, Fig. 15)

Thalassiosira lentiginosa var. ovalis (Castracane) Fryxell

Basionym. Coscinodiscus ovalis Castracane, 1886, p. 160, pl. 7, fig. 4 , pl. 18 , fig. 7 , and pl. 23

Synonym. Coscinodiscus lentiginosus f. obovatus (Castracane) Ciesielski, 1983, pl. 4, figs. 4-8; DeFelice, 1979, pp. 127-129 
Thalassiosira maculeata Johansen and Fryxell, 1985, p. 170, figs. 13, $69,70,72-74$, and $77-80$

Synonym. Coscinodiscus bullatus Janisch sensu Hustedt, 1958, p. 112 , figs. 26-28, according to Johansen and Fryxell, 1970. We think that Hustedt illustrates two different diatom species in his 1958 paper under the name $C$. bullatus. We do not agree that Janisch's $T$. bullatus are of $T$. maculeata, and we assign them to our new species $T$. fasciculata.

Thalassiosira mahoodii Barron, in Baldauf and Barron, in press, pl. 2, figs. $3-5$, pl. 3 , figs. 2 and 4 , and pl. 4 , figs. $1-5$

Thalassiosira miocenica Schrader, 1974, p. 916, pl. 22, figs. 1- 5 and 11-13; Barron, 1985a, pl. 11, fig. 11; Baldauf and Barron, 1991, pl. 6, fig. 2

Thalassiosira oestrupii (Ostenfeld) Proschkina-Lavrenko; Schrader, 1973a, p. 712 , pl. 11, figs. 16-22, 26-33, 36, and 39-45. (Plate 16, Figs. 5-7)

Thalassiosira oliverana (O'Meara) Sournia

Synonyms. Actinocyclus oliveranus O'Meara, 1877, p. 58, pl. 1, fig. 7; Castracane, 1886, p. 145, pl. 4, fig. 7; Brown, 1920; Schimperiella antarctica (Grunow) Karsten, 1905, p. 88, pl. 8, fig. 6; Abbott, 1974, p. 319 , pl. 2, figs. D-F; Fenner et al., 1976, p. 779, pl. 14, figs. 1-5; Akiba, 1982, p. 45, pl. 3, figs. 1-6; T. umbonatus Castracane, 1886, p. 145 , pl. 4, fig. 4. Also see discussion in paper by Makarova and Nikolaev (1984).

Remarks. Several different morphotypes are noted separately in the distribution tables, as "coarse" variety (Plate 14, Figs. 6 and 11) referring to the coarse areolar pattern, and "umbonatus" referring to Castracane's species. (Plate 14, Figs. 1, 2, 6, 11, and 17)

Thalassiosira oliverana var. sparsa var, nov.

Synonyms. Cosmiodiscus intersectus (Brun) Jousé, sensu McCollum, 1975, pl. 8, fig. 4; Gersonde and Burckle, 1990, pl. 4, fig. 13; Baldauf and Barron, 1991; Cosmiodiscus insignis sensu Harwood, 1986b, pl. 8, figs. 4-6; Thalassiosira oliverana (O'Meara) variety of Harwood et al., 1989b, pl. 2, fig. 7

Diagnosis. Valve circular, convex; differs from $T$. oliverana by the presence of a large, distinct hyaline area from the center of the valve to one-half valve radius; sparse puncta present in hyaline area, but the radial pattern of areolae stop near one-half radius; several processes usually scattered near valve center; margin striate, broad.

Remarks. This diatom may merit species status, separate from $T$. oliverana. Quincunx pattern well developed near margin.

Holotype. USNM Collection 458231 (Plate 16, Fig. 13)

Type level and locality. upper Miocene, Sample 120-751-5H-6, 10-11 cm, Kerguelen Plateau. (Plate 16, Fig. 13)

Thalassiosira praelineata Jousé; Jousé, 1977. (Plate 5, Figs. 6-9)

Thalassiosira primalabiata Gombos, in Gombos and Ciesielski, 1983, pl. 9, figs. 1-8

Thalassiosira ritscherii (Hustedt) Hasle, 1968, p. 196; Hasle and Heimdal, 1970, pp. 569-570, figs. 39-43 and 54; Hargraves, 1968 figs. 194-195; Johansen and Fryxell, 1985, p. 176, figs. 14 and 56-57 44-46

Basionym. Coscinodiscus ritscherii Hustedt, 1958, p. 117, figs.

Synonym. Thalassiosira sp. of Harwood, 1986a, pl. 27, fig. 9. (Plate 16, Figs. 1-3)

Thalassiosira spinosa Schrader, 1976, p. 636, pl. 6, figs. 5-7

Thalassiosira spumellaroides Schrader, 1976, p. 636, pl. 6, figs. 1, 2; Barron, 1985b, fig. 5.4 .

Thalassiosira striata sp. nov.

Synonym. Coscinodiscus bullatus Janisch, 1888, pl. 6, fig. 12, but not $C$. bullatus Janisch sensu Hustedt, 1958 (see above discussion for T. fasciculata); C. planisculus Harwood, 1986a, pl. 16, figs. 10-11

Description. Valve flat to slightly convex, or gently undulating; areolae $(7-8$ in $10 \mu \mathrm{m})$ of even size across valve face, arranged in weakly developed fascicules and in gently curving tangential rows radial rows of areolae are parallel to the longest row, which is located in the middle of the fascicule; valve mantle associated with a ring of elongate areolae; up to 40 processes (strutted?) on valve face; margin striate.

Remarks. Species not observed in SEM.

Holotype. USNM Collection 458232 (Plate 15, Fig. 7)

Type level and locality. lower Pliocene, Sample 120-751A-3H-5, 105-106 cm, Kerguelen Plateau. (Plate 15, Figs. 7-9)

Thalassiosira striata var.

Remarks. Smaller forms of $T$. striata often show inner radial lines of areolae converging at a severely eccentric, subcentral position. Beside this variation in the pattern of areolae rows, other structures suggest a position within $T$. striata. This form was also noted in the upper Pliocene from Cockburn Island and as a recycled specimen in the Sirius Group by Harwood, 1986a, pl. 27, fig. 14 and pl. 4, fig. 6 . (Plate 16, Fig. 14)

Thalassiosira torokina Brady, 1977, pp. 122-123; Brady, 1979, pl. 4, figs. 1-5; Ciesielski, 1983, pl. 7, figs. 3-6; Harwood, 1986a, pl. 15, figs. 11 and $13-14$, pl. 19 , figs. $10-11$, and pl. 25 , figs. $1-3$

Thalassiosira tumida (Janisch) Hasle in Halse et al. 1971, pp. 328330, figs. 1-43 and 46; Fenner et al., 1976, p. 780, pl. 10, figs. 6-7; Johansen and Fryxell, 1985, p. 176, figs. 28-32.

Thalassiosira vulnifica (Gombos) Fenner, in press

Basionym. Coscinodiscus vulnificus Gombos, 1977, p. 593, pl. 4, figs. 1-3 and pl. 42, figs. 1-2; Brady, 1979, pl. 6, fig. 5; Ciesielski, 1983 , p. 656 , pl. 6, Figs. 7-8; Barron, 1985b, pl. 6, Fig. 19; Harwood, 1986 a, p. 210 , pl. 16 , figs. $15-17$, pl. 27 , figs. $12-13$

Synonym. Coscinodiscus sp. 2 of McCollum, 1975, p. 527, pl. 8, figs. 1-2. (Plate 15, Fig. 1)

Thalassiosira webbi sp. nov.

Synonyms. Thalassiosira sp. A of Harwood, 1986a, p. 217, pl. 15, fig. 15 .

Description. Valve circular, flat to slightly undulating, with slightly elevated ring at one-half radius; areolae, hexagonal, of even size over most of valve but smaller near center, arranged in linear rows, tangential to the margin; central circle of 15-25 strutted processes are present within a four-areolae radius from the center; ring of areolae disrupts linear arrangement of areolae.

Remarks. Related to $T$. tumida, but differs by the distinct ring of processes in center of the valve. Named after Professor P. N. Webb.

Holotype. USNM Collection 458233 (Plate 15, Fig. 3)

Type level and locality. mid-Pliocene, Sample 120-751A-3H-1, $47-48 \mathrm{~cm}$, Kerguelen Plateau. (Plate 15, Figs. 2-3)

Thalassiosira sp. A. (Plate 16, Fig. 4)

Thalassiosira sp. B. (Plate 19, Figs. 5-7)

Thalassiosira sp. C. (Plate 16, Figs. 8-10)

Thalassiothrix longissima Cleve and Grunow, 1880; Schrader, 1976, . p. 637 , pl. 1, figs. 5-6 and 17. (Plate 11, Fig. 12)

Triceratium castelliferum Grunow, in Schmidt et al., 1874-1959, pl. 128 , figs. $17-18$, pl. 152 , fig. 18; Hajos, 1976, pl. 12, figs. 4-5. (Plate 1, Fig. 6)

Triceratium condecorum Brightwell; Fenner, 1979, pl. 28, fig. 7, pl. 29 , fig. 1

Triceratium groningensis Reinhold, 1937, p. 126, pl. 20, fig. 9; Gombos and Ciesielski, 1983, p. 605 , pl. 15, figs. 1-3

Triceratium inconspicuum Greville var. triloba Fenner, 1979, p. 534, pl. 30, figs. 23-26; Fenner, 1985, p. 740, figs. 8.12-8.16; Barron et al., 1984 , p. 158 , pl. 6 , figs. $6-7$

Triceratium kanayae var. quadrilobata Fenner, as T. schulzii var. quadrilobata in Fenner, 1979, pl. 30, figs. 15-20

Triceratium pileus Ehrenberg; Barron, 1985a, pl. 6, fig. 10

Triceratium polymorphus sp. nov.

Synonyms. Triceratium hebetatum vars. A, B, and C of Harwood, 1989, pp. 81-82, pl. 3, figs. 2-6; Triceratium macroporum Hajós, sensu Gombos and Ciesielski, 1983, pl. 17, figs. 4-6: (?) Gombos, 1983, p. 571; Triceratium schulzii Jousé, sensu Schrader and Fenner, 1976, pl. 27, figs. $14-15$ 
Description. Valve triangular with broadly rounded ends; sides straight to broadly concave; valve face covered with coarse areolae, with sporadic distribution of finer punctae between the coarse areolae; two corners with structure similar to the rest of the valve face and bearing labiate processes; third corner possesses a field of smaller pores, pseudocellus, that is mostly present on the mantle.

Discussion. This diatom belongs to a group of Triceratium that bear a dense pore field (pseudocellus) on only one of the corners of the valve. Other members of this group, which perhaps could be separated from Triceratium, include Triceratium hebetatum (Grunow in Van Heurck) Andrews 1980, p. 35, pl. 3, figs. 20-21 (from the middle Miocene); pl. 6, fig. 6; Triceratium (Biddulphia) irregular var. hebetata Grunow in Van Heurck 1883, pl. 111, fig. 10; Triceratium impar Schmidt in Schmidt et al., 1874-1959, pl. 151, figs. 31-34; Triceratium inelegans Greville sensu McCollum 1975, p. 536, pl. 14, figs. 8-9, and perhaps other species where the heteropolar nature of the angles was not previously observed. Many diatoms identified as Triceratium condecorum should be reevaluated in light of this distinction and because of the confusion resulting from a typographical error in Schmidt et al., in which pl. 76, fig. 27, should read fig. 28 for $T$. condecorum. Other species to study include $T$. macroporum Hajos, 1968 (from the middle Miocene); $T$. condecorum in Maruyama, 1984, pl. 15, fig. 6; Triceratium seychellensis in Fenner, 1979, pl. 28; and Triceratium lapetes Fenner, in Schrader and Fenner, 1976, p. 1003, pl. 26, fig. 12.

Discussion. The diagnostic feature of this diatom is the presence of a pseudocellus composed of fine pores on only one corner of the valve, distinguishing it from morphologically similar Triceratium condecorum Brightwell (see Hanna, 1932, and Andrews, 1976). Three forms of this species were identified in CIROS-1 (Harwood, 1989) based on variations in valve shape. The variable valve concavity was also noted here and in Gombos and Ciesielski (1983) for the species they refer to as Triceratium macroporum.

Holotype. USNM Collection 458234 (Plate 1, Fig. 1)

Paratype. USNM Collection 458235 (Plate 1, Fig. 3)

Type level and locality. lower Oligocene, Sample 120-748B-14H-1, 116-118 cm, Kerguelen Plateau. (Plate 1, Figs. 1-3)

Triceratium unguiculatum group Greville, 1864, sensu Gombos, 1977, p. 598; Gombos and Ciesielski, 1983, p. 605.

Remarks. This group includes other diatom species such as Triceratium pulvinar; see Gombos and Ciesielski (1983) and Sims and Ross (1990).

Trinacria excavata Heiberg, 1863, p. 51, pl. 4, fig. 9; Hendey, 1981, p. 85; Gombos and Ciesielski, 1983, p. 605, pl. 17, fig. 8; Harwood, 1986 a, p. 87 , pl. 2 , fig. 13

Tropidoneis antarctica (Grunow) Cleve; Hustedt, 1958, pp. 149-150; Fenner et al., 1976, p. 781, pl. 14, fig. 8

Xanthiopyxis acrolopha Forti, 1912, p. 84; Hajos, 1976, p. 826, pl. 11, fig. 6, pl. 17, fig. 12; Fenner, 1979, p. 536, pl. 35, figs. 25-26; McCollum, 1975, p. 536 (misspelled $X$. acrolophra) pl. 15, figs. 4-5

Xanthiopyxis oblonga Ehrenberg, 1844; Fenner, 1979, p. 536, pl. 35, fig. 9

Xanthiopyxis panduraeformis Pantocsek, 1886, p. 43, pl. 29, fig. 297; Hajós, 1976, p. 826, pl. 11, fig. 5, and pl. 7, fig. 9 


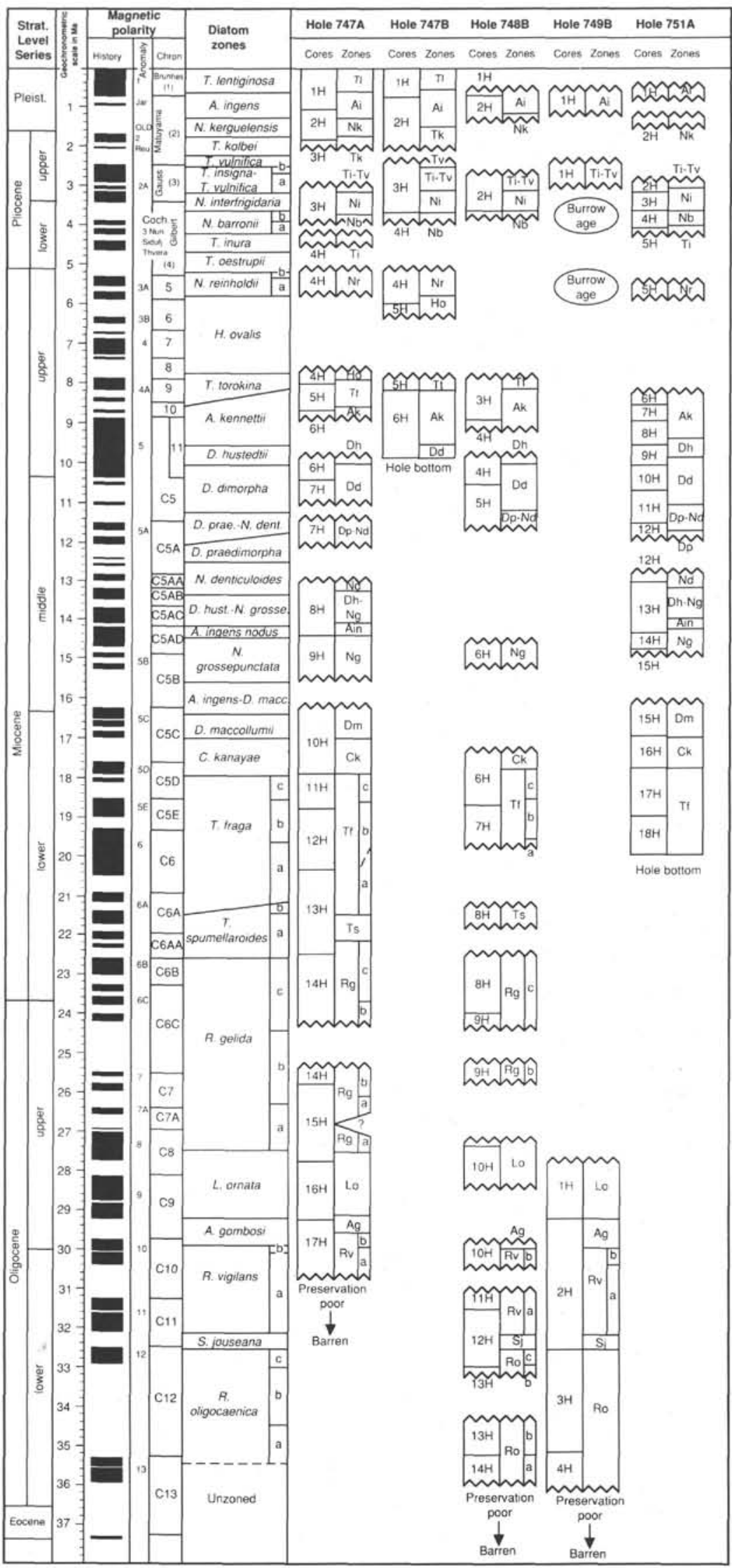

Figure 16. Summary figure showing the ages of Oligocene to Holocene sediments recovered by Leg 120, indicating the duration and position of hiatuses. Relative sediment accumulation rates are evident by the length of each core or section, as in Figure 9 of Harwood et al. (this volume). 
Table 15. Composite list of Pliocene-Pleistocene diatom events and ages from prior studies and by extrapolation from the age-depth plots of Harwood et al. (this volume).

\begin{tabular}{|c|c|c|c|c|c|c|}
\hline Zone & Datum & Age & $\begin{array}{c}\text { Published } \\
\text { age }\end{array}$ & $\begin{array}{c}\text { Hole } \\
\text { 747A (747B) } \\
\end{array}$ & $\begin{array}{l}\text { Hole } \\
748 B \\
\end{array}$ & $\begin{array}{l}\text { Hole } \\
751 \mathrm{~A}\end{array}$ \\
\hline T. Lentiginosa & $T \cdot H$. karstenii & 0.195 & $0.195 \mathrm{Bu}$ & 0.2 & & \\
\hline A. ingens & ${ }^{*} \mathrm{~T}$ A. ingens & 0.62 & $0.62 \mathrm{C} 0.6 \mathrm{G}$ & 0.6 & 0.6 & 0.6 \\
\hline A. ingens & $T T . s p . B$ & $0.8-1.0$ & & 0.8 & 1 & \\
\hline A. ingens & TT. elliptipora & 0.65 & $0.65 \mathrm{C}$ & 0.8 & 0.8 & 0.6 \\
\hline A. ingens & TA.sp.C & 0.8 & & & 0.8 & \\
\hline N. kerguelensis & ${ }^{*} \mathrm{~T}$ N. barronii & 1.25 & & 1.25 & 1.25 & $>0.6<1.4$ \\
\hline N. kerguelensis & $B T$.sp. B & 1.3 & & 1.4 & -1.1 & \\
\hline N. kerguelensis & $T T$, torokina & 1.8 & $2.1 \mathrm{~B}$ & & & $>1.7<3.0$ \\
\hline N. kerguelensis & $T T$. fasciculatus & 1.6 & & & & -1.6 \\
\hline N. kerguelensis & BA.sp.C & 1.7 & & & & 1.7 \\
\hline N. kerguelensis & $B T$. fasciculatus & 1.7 & & 1.9 & $>1.5<2.9$ & 1.6 \\
\hline N. kerguelensis & TA. maccollumii & $>1.7<2.8$ & & & $>1.5<2.9$ & $>1.7<3.0$ \\
\hline$N$, kerguelensis & B A. fasciculatus & $1.7 \cdot 2.8$ & & $>2.1<3.1$ & $>1.5<2.9$ & $>1.7<3.0$ \\
\hline N. kerguelensis & B T. elliptipora & 1.6 & $2.2 \mathrm{C} \quad 1.55-1.75 \mathrm{~B}$ & 1.4 & $\begin{array}{l}>1.5<2.9 \\
>1.5<2.9\end{array}$ & $>1.7<3.0$ \\
\hline T. kolbei & •T T. kolbei & 1.8 & $\begin{array}{llll}1.8 \mathrm{G} & 1.89 \mathrm{C} & 1.9 \mathrm{~B}\end{array}$ & 1.8 & $>1.5<2.9$ & $>1.7<3.0$ \\
\hline T. kolbei & $T T$. inura & 1.8 & & 1.9 & $>1.5<2.9$ & $>1.7<3.0$ \\
\hline T. kolbei & TA. fasciculatus & 1.8 & & $>2.1<3.1$ & $\begin{array}{l}>1.5<2.9 \\
>1.5<2.9\end{array}$ & $>1.7<3.0$ \\
\hline T. vulnifica & •T T. vulnifica & 2.2 & $2.22 \mathrm{~W} 2.2 \mathrm{~B}$ & $>2.1<3.1$ & $>1.5<2.9$ & $>1.7<3.0$ \\
\hline T. vulnifica & TA. karstenii & $1.7-2.8$ & & & $>1.5<2.9$ & \\
\hline T. vulnifica & $B T$. gracilis & 2.2 & & 1.9 & 1.1 & $>1.7<3.0$ \\
\hline$T$. vulnifica & $T R$. diploneides & 2.4 & 2.4 & $>2.1<3.1$ & $\begin{array}{l}>1.5<2.9 \\
>1.5<2.9\end{array}$ & $>1.7<3.0$ \\
\hline$T$. insigna $-T$. vulnifica b & •T T, insigna & 2.5 & $2.49 \mathrm{C} 2.5 \mathrm{G} \quad 2.4-2.45 \mathrm{~B}$ & $>2.1<3.1$ & $>1.5<2.9$ & $>1.7<3.0$ \\
\hline T. insigna $-T$. vulnifica $b$ & TS.sp. I\& 2 Brady & 2.9 & & & $>1.5<2.9$ & 3.1 \\
\hline T. insigna $-T$. vulnifica $b$ & $T T$. lent. ovalis & 2.4 & 2.4 & $>2.1<3.1$ & $>1.5<2.9$ & $>1.7<3.0$ \\
\hline$T$. insigna $-T$, vulnifica $b$ & $T N$. interfrigidaria & 2.6 & $2.5 \mathrm{~W} \quad 2.8 \mathrm{C} \quad 2.6-2.7 \mathrm{~B}$ & $>2.1<3.1$ & $>1.5<2.9$ & $>1.7<3.0$ \\
\hline$T$, insigna $-T$. vulnifica $b$ & $T R$. heteropolara & 2.5 & 2.5 & & 3.5 & \\
\hline$T$. insigna $-T$. vulnifica a & $\bullet \mathrm{T} \mathrm{N}$. weaveri & 2.64 & $2.64 \mathrm{C} \quad 1.75-1.9 \mathrm{~B}$ & $>2.1<3.1$ & 2.9 & $>1.7<3.0$ \\
\hline$T$. insigna $-T$, vulnifica a & TT. complicata & $3.1 \cdot 3.3$ & $2.5 \mathrm{G}$ & 3.3 & 2.9 & 3.1 \\
\hline$T$. insigna $-T$, vulnifica $a$ & $T T$. webbi & 2.8 & & & 2.9 & $>1.7<3.0$ \\
\hline$T$. insigna $-T$, vulnifica a & $T T$. striata & $2.8-3.2$ & & & 2.8 & 3.2 \\
\hline$T$. insigna $-T$. vulnifica a & B A maccollumit & $2.8-3.1$ & & & 2.9 & $>1.7<3.0$ \\
\hline$T$. insigna $-T$, vulnifica a & BN. kerguelensis & 3.1 & $2.7 \mathrm{M}$ & $>2.1<3.1$ & 2.9 & $>1.7<3.0$ \\
\hline T. insigna - T. vulnifica a & BA. actinochilus & 3 & $2.2-2.5 \mathrm{G} \& \mathrm{~B}$ & $>2.1<3.1$ & 0 & $>1.7<3.0$ \\
\hline$T$. insigna $-T$, vulnifica $a$ & TR. barboi (local) & 3.1 & 1.58 & 3.25 & 3.4 & 3 \\
\hline$T$. insigna $-T$, vulnifica $a$ & •B T. vulnifica & 3.1 & $3.1 \mathrm{C} 2.7 \cdot 2.8 \mathrm{~B}$ & 3.1 & 3.1 & 3.1 \\
\hline N. interfrigidaria & $B N$. weaveri & 3.2 & $3.1 \mathrm{~B}$ & 3.3 & & 3.2 \\
\hline N. interfrigidaria & $T T . s p . C$. & 3.2 & & & & 3.2 \\
\hline N. interfrigidaria & B T. lentiginosa ovalis & 3.2 & & 3.1 & & 3.2 \\
\hline N. interfrigidaria & B T. insigna & 3.2 & & 3.2 & 3.1 & $3.25 \cdot 3.4$ \\
\hline N. interfrigidaria & TN. reinholdii & 3.2 & & 3.2 & 3.8 & 3.4 \\
\hline N. interfrigidaria & $B T$, webbi & 3.25 & & & 3.3 & $3.25 \cdot 3.4$ \\
\hline N. interfrigidaria & BN. curta & 3.5 & & & 3.5 & \\
\hline$N$. interfrigidaria & BN. ritscherii & 3.4 & & 3.1 & 2.9 & 3.6 \\
\hline N. interfrigidaria & $T N$ praeinterfrigidaria & 3.5 & $3.52 .8 \mathrm{C}$ & $3.4-3.5$ & 3.3 & 3.5 \\
\hline N. interfrigidaria & TN. wisei & 3.5 & & & 3.5 & 3.5 \\
\hline N. interfrigidaria & $T N$ praecurta & 3.6 & 3.6 & 4.2 & & \\
\hline N. interfrigidaria & $T N$ arcula & 3.6 & $3.6 \mathrm{G}$ & 4.2 & 3,7 & 3.9 \\
\hline N. interfrigidaria & •B N. interfrigidaria & 3.6 & $3.6 \mathrm{G} 3.6 \mathrm{~B}$ & 3.5 & 3.6 & 3.7 \\
\hline N. barronii b & B P. alata gp. & 3.8 & & 3.5 & 3.8 & $3.75-3.8$ \\
\hline N. barronii b & TN. aurica & 3.8 & 3.8 & $>3.5<4.2$ & 3.7 & 3.9 \\
\hline N. barroniï a & "T R. costata & 3.9 & $3.9 G$ & 3.4 & 3.9 & 3.9 \\
\hline N. barronï a & $T T$. nitzschioides parva & 3.9 & & $>3.5<4.2$ & 3.9 & 4.1 \\
\hline N. barronit a & B T. lentiginosa & 3.9 & 3.8 & 4.2 & 3.9 & 3.9 \\
\hline N. barronii a & B T kolbei & 3.8 & $3.8 \quad 2.8 \mathrm{~B}$ & $>3.5<4.2$ & 3.9 & 3.9 \\
\hline$N$, barronii a & TR.sp.C & 4.1 & & & & 4.1 \\
\hline N. barronii a & BT . striata & 4.1 & & & 3.3 & 4.1 \\
\hline N. barronii a & BR.sp.D & 4.1 & & & 3 & 4.1 \\
\hline N. barronii a & B N. wisei & 4 & & & 3.8 & 4.1 \\
\hline N. barronii a & B A parvulus & 4.1 & & & 3 & 4.1 \\
\hline N. barronï̈ a & B R . diploneides & 4,1 & & $>3.5<4.1$ & 3.6 & 4 \\
\hline N. barronii a & B T fasciculatus & 4.1 & & $>3.5<4.1$ & 3.9 & 4.1 \\
\hline N. barronii a & ${ }^{\bullet B}$ N barronii & 4.1 & $4.2 \mathrm{G} \quad 4.0-4.4 \mathrm{~B}$ & 4.2 & $>3.9<8.0$ & 3.9 \\
\hline$N$. inura & TR. heteropolara var. A & 4.1 & & & $>3.9<8.0$ & 4.1 \\
\hline$T$, inura & BN. lacrima & 4.3 & 4.3 & & & $>4.4<5.6$ \\
\hline T. inura & $B R$. heteropolara & 4.3 & $4.3 \mathrm{G} 3.8 \mathrm{~B}$ & 4.3 & $>3.9<8.0$ & $>4.4<5.6$ \\
\hline T. inura & B T. complicata & 4.3 & $4.3 \mathrm{G}$ & $>4.2<5.3$ & $>3.9<8.0$ & 4.4 \\
\hline T. imura & $T T$. oliverana sparsa & 4.5 & 4.5 & $>4.2<5.3$ & $>3.9<8.0$ & 4.3 \\
\hline$T$. imura & BN.praeinterfrigidaria & 4.5 & $4.35-4.55 \mathrm{~B} \quad 4.7 \mathrm{G}$ & $>4.2<5.3$ & $>3.9<8.0$ & $>4.4<5.6$ \\
\hline$T$, inura & ${ }^{*} \mathrm{~B} * \mathrm{~T}$. inura & $4.5(4.8)$ & $4.8 \mathrm{~B} \quad 4.47 \mathrm{G} \quad 6.0 \mathrm{~B}$ & $>4.2<5.3$ & $>3.9<8.0$ & $>4.4<5.6$ \\
\hline T. oestrupii & $T N$, miocenica & 5.1 & $5.1 \mathrm{Ba}$ & & & 5.8 \\
\hline T. oestrupii & *B T. oestrupii & 5.1 & $5.1-5.3 \mathrm{~B} \quad 5.1 \mathrm{Ba}$ & $>4.2<5.3$ & $>3.9<8.0$ & $>4.4<5.6$ \\
\hline
\end{tabular}

Notes: Datums that define zone boundaries are in bold; $\mathrm{T}=$ top of range; $\mathrm{B}=$ base of range; $\mathrm{T}^{*} \mathrm{~B}^{*}=$ abundance/consistency datum. Abbreviations in the "Published ages" column correspond to the following sources: Bu = Burckle et al. (1978), C = Ciesielski (1983), $\mathrm{G}=$ Gersonde and Burckle (1990), W = Weaver and Gombos (1981), $\mathrm{M}=\mathrm{McC}$ collum (1975), $\mathrm{Ba}=$ Barron (in press), $\mathrm{Bn}=$ Barron (1985b), and $\mathrm{B}=$ Baldauf and Barron (1991). 
Table 16. Composite list of Miocene diatom events and ages from prior studies and by extrapolation from the age-depth plots of Harwood et al. (this volume).

\begin{tabular}{|c|c|c|c|c|c|c|}
\hline Zone & Datum & $\begin{array}{l}\text { Age } \\
\text { (Ma) }\end{array}$ & $\begin{array}{l}\text { Published } \\
\text { ages }\end{array}$ & $\begin{array}{l}\text { Hole } \\
747 \mathrm{~A}\end{array}$ & $\begin{array}{l}\text { Hole } \\
748 B\end{array}$ & $\begin{array}{l}\text { Hole } \\
751 \mathrm{~A}\end{array}$ \\
\hline$\overline{N . \text { reinholdii } b}$ & TN. donahuensis & 5.3 & & $>4.2<5.2$ & & 5.7 \\
\hline$N$. reinholdii $b$ & $T A$. ingens var. $A$ & 5.3 & & $>4.2<5.2$ & $>3.9<8.0$ & 5.7 \\
\hline N. reinholdii a & ${ }^{*} \mathrm{~T}$ H. triangularis & 5.3 & & $>4.2<5.2$ & & 5.8 \\
\hline$N$. reinholdii a & ${ }^{* T}$ N. mirabilis & 5.3 & 5.6 & $>4.2<5.2$ & & 5.8 \\
\hline$N$, reinholdii a & TA, concavus & 5.5 & & & & 5.7 \\
\hline$N$. reinholdii a & THemidiscus sp. 2 & 5.7 & & & & 5.8 \\
\hline N. reinholdii a & TH. karsteniif. I & 5.7 & & & & 5.8 \\
\hline$N$. reinholdii a & $T^{*} D$. hustedtii & $5.6-5.7$ & 6.3 & $5.6-5.7$ & & \\
\hline N. reinholdii a & $T A$. kennettii & 5.7 & $7.1 \mathrm{G} 5.6 \mathrm{C} 8.6-8.9 \mathrm{~B}$ & 5.6 & $>3.9<8.0$ & 5.7 \\
\hline N. reinholdii a & TH. ovalis & 5.7 & $7.2 \mathrm{G}$ & $>4.2<5.2$ & & 5.8 \\
\hline$N$. reinholdit a & $B T, s p \cdot C$ & 5.7 & & & & 5.8 \\
\hline$N$, reinholdii $a$ & $B$ H. triangulus & 5.6 & $6.45 .6 \mathrm{C}$ & $>5.8<7.7$ & & $>6.0<8.4$ \\
\hline N. reinholdii a & $B T$. oliverana & 5.8 & & $>5.8<7.7$ & $>3.9<8.0$ & \\
\hline N. reinholdii a & BN. reinholdii & 5.8 & 5.6 & $>5.8<7.7$ & $>3.9<8.0$ & $>6.0<8.4$ \\
\hline N. reinholdii $a$ & *B T. miocenica & 5.8 & $5.8 \mathrm{~B}$ & & & 5.8 \\
\hline H. ovalis & $B A$. ingens var. $A$ & 7.9 & & 7.9 & & \\
\hline H. ovalis & TL. minisculum & 7.9 & & 7.9 & & \\
\hline H. ovalis & •B H. ovalis & 7.9 & $7.4 \mathrm{~B} 7.9 \mathrm{G}$ & 7.9 & & \\
\hline T. torokina & TD. dimorpha & 8 & 8 & & 8.1 & \\
\hline T. torokina & B T. oliverana sparsa & 7.9 & $7.9 \mathrm{G} 7.8 \mathrm{~B}$ & 7.9 & & \\
\hline T. torokina & B H. karsteniif. I & 8.1 & & & 8.1 & \\
\hline T. torokina & $\bullet$ B T. torokina & $8.2(8.6)$ & $7.7 \mathrm{G} 8.2 \mathrm{C} \quad 7.9-8.2 \mathrm{~B}$ & 8.5 & 8.2 & $>6.0<8.4$ \\
\hline T. torokina & B L. minisculum & 8.6 & & 8.5 & & \\
\hline A. kennetrii & $B D$. hustedtii ovalis & 8.7 & & 8.7 & & \\
\hline A. kennettii & B N. donahuensis & 8.8 & & 8.5 & & 8.8 \\
\hline A. kennettii & B H. karstenii & 8.7 & 8.7 & $>9.0<9.8$ & 8.7 & \\
\hline A. kennettii & *B A. kennettii & 9.6 & $9.6 \mathrm{G} 9.6 \mathrm{~B}$ & $>9.0<9.8$ & $>9.3<10$ & 9.7 \\
\hline \multicolumn{7}{|l|}{ D. hustedtii } \\
\hline D. dimorpha & ${ }^{*} \mathrm{~T} \bullet \mathrm{D}$. dimorpha & 10.1 & $9.9 \mathrm{~B} \quad 9.8 \mathrm{G}$ & 10.1 & 10.1 & 10.1 \\
\hline D. praedim. - N dentic. & *T D. praedimorpha & 11.1 & $11-11.1 \mathrm{~B} \quad 10.4 \mathrm{G} \quad 10.5 \mathrm{C}$ & 10.9 & 11.3 & 11.1 \\
\hline D. praedim. - N. dentic. & *T N. denticuloides & 11.3 & $11.5 \mathrm{G} \quad 11.4 \mathrm{~B}$ & 11.1 & 11.3 & 11.1 \\
\hline D. praedim - N dentic. & TA, oligocenica & 11.5 & & 14.2 & 11.5 & \\
\hline D. praedim. - N. dentic. & B A. karstenii & 11.7 & 10. B & $1.1-11.5$ & & 9.1 \\
\hline D. praedim - N. dentic. & $B A$ ingens var. $A$ & 11.8 & & & $>11.8<14.5$ & \\
\hline D. praedim. $-N$ dentic. & TD. nicobarica & 12 & $12 \mathrm{~B} \quad 12.2$ & $12-12.1$ & & 12 \\
\hline D. praedim. - N dentic. & *B D. dimorpha & $11.9(12.2)$ & $11.9 \mathrm{~B} \quad 12.4 \mathrm{G}$ & 11.9 & $>11.8<14.5$ & 11.9 \\
\hline D. praedimorpha & BS. barboi & 12.5 & $11.2 \mathrm{G} 11.4 \mathrm{~B}$ & $>12.2<13.1$ & & \\
\hline D. praedimorpha & $T A$. ingens nodus & 12.3 & $12.3 \mathrm{G} \quad 12-12.5 \mathrm{~B}$ & $>12.2<13.1$ & & 11.9 \\
\hline D. praedimorpha & *B D. praedimorpha & 12.6 & $12.6 \mathrm{G} \quad 12-12.5 \mathrm{~B}$ & $>12.2<13.1$ & $>11.8<14.5$ & 12.8 \\
\hline N. denticuloides & $T N$ grossepunctata & 12.6 & $11.9-12 \mathrm{~B} \quad 13.5 \mathrm{G}$ & 13.2 & $>11.8<14.5$ & 12 \\
\hline N. denticuloides $\mathrm{Zn}$ & T. C. lewisianus & 13.2 & 12.9 & 13.2 & $>11.8<14.5$ & 14.2 \\
\hline$N$. denticuloides & *B N. denticuloides & 13.5 & $13.5 \mathrm{G} \quad 13.3-13.4 \mathrm{~B}$ & 13.6 & $>11.8<14.5$ & 13.6 \\
\hline D. hustedtii-N. grosse. & *B D. hustedtii & 14.2 & $14.2 \mathrm{G} \quad 14-14.2 \mathrm{~B}$ & 14.2 & $>11.8<14.5$ & 14.1 \\
\hline A. ingens nodus & TD. maccollumii & 14.4 & 14.4G $12 \mathrm{~B}$ & 14.6 & $>11.8<14.5$ & 14 \\
\hline A. ingens nodus & "B* A. ingens nodus & 14.5 & $14.9 \mathrm{G} \quad 13.8-14 \mathrm{~B}$ & 14.6 & $>11.8<14.5$ & 14.3 \\
\hline N. grossepunctata & TS. jouseana & 14.7 & $14.6 \mathrm{~B}$ & 14.7 & $>11.8<14.5$ & 14.6 \\
\hline N. grossepunctata & *B N. grossepunctata & 15.5 & $15.3 \mathrm{G} \quad 15.2 \mathrm{~B}$ & 15.5 & $>11.8<14.5$ & 15.3 \\
\hline A. ingens - D. maccollumii & $T R$ marylandica & $\sim 14$ & 15.3 & $16.3-16.5$ & $>11.8<14.5$ & $16.8-17.2$ \\
\hline A. ingens - $D$. maccollumii & $T N$. maleinterpretaria & 14.1 & $15.6 \quad 15.0 \mathrm{~B} \quad 14.6 \mathrm{G}$ & & $>11.8<14.5$ & 16.6 \\
\hline A. ingens - D. maccollumii & $B D$. hyalina & 15 & $15 B$ & & & \\
\hline A. ingens - D. maccoltumii & B D. lauta & 16 & $16 \mathrm{~B}$ & $>15.6<16.3$ & & 15.7 \\
\hline A. ingens - D. maccollumii & ${ }^{*} B * A$. ingens & 16.4 & $16.4 \mathrm{~B} \quad 15.2 \mathrm{G}$ & $>15.6<16.3$ & $>11.8<14.5$ & 15.7 \\
\hline D. maccollumii & •B D. maccollumii & 17 & $16.7-17.2 \mathrm{~B}<16.6 \mathrm{G}$ & 17 & $>16<17.7$ & 16.9 \\
\hline C. kanayae & $B$ C. nicobarica & 17.8 & $17.8 \mathrm{~B}$ & & & \\
\hline C. kanayae & *B C. kanayae & 18 & $17.6-17.9$ & 17.8 & 18 & 18.1 \\
\hline T. fraga $c$ & TC. rhombicus & 18.1 & & 19.6 & 18.1 & 18.2 \\
\hline$T$. fraga $c$ & $B N$. mirabilis & 18.3 & & 17.8 & 18.3 & \\
\hline T. fraga $b$ & *T. T. fraga & 18.6 & $18(16.2)$ & 18.6 & 17.7 & 18.1 \\
\hline T. fraga $b$ & TA. symmetricus & 18.6 & & 22.6 & 18.6 & \\
\hline T. fraga $b$ & $T T$. spumellaroides & 19.3 & $20.2-20.3 B$ & & 19.3 & \\
\hline T. fraga a & ${ }^{* T}$ R. symmetrica & 19.7 & & 22.6 & 19.7 & \\
\hline T. fraga a & *B T, fraga & $21.2(21.5)$ & $20.8 \mathrm{~B} \quad 19.9 \mathrm{Ba}$ & 21.5 & 21.7 & \\
\hline$T$. spumellaroides $a$ & ${ }^{*}$ T A.gombosi & 21.5 & & $23.8-24.2$ & 21.5 & \\
\hline T. spumellaroides a & $B R$ marylandicus & 22 & & $21.8-22$ & 19.5 & \\
\hline$T$. spumellaroides a & $T T$, primalabiata & 22.3 & $22.2 \mathrm{~B} \quad 21.7 \mathrm{Ba}$ & 22.6 & $>21.2<22.3$ & \\
\hline T. spumeliaroides a & TH. taurus & 22.3 & & 23.8 & $>21.2<22.3$ & \\
\hline T. spumellaroides a & $T R$, gelida & 22.4 & $22.7 \mathrm{Bn} 21.8-22.1 \mathrm{~B}$ & $22.0-22.4$ & $>21.2<22.3$ & \\
\hline$T$. spumellaroides a & *B T. spumellaroides & 22.6 & $>20.5 \mathrm{G} \quad 22.6-22.7 \mathrm{~B}$ & 22.6 & $>21.2<22.3$ & \\
\hline
\end{tabular}

Note: Datums that define zone boundaries are in bold; $\mathrm{T}=$ top of range; $\mathrm{B}=$ base of range; $\mathrm{T}^{*} \mathrm{~B}^{*}=$ abundance/consistency datum. Abbreviations in the "Published ages" column correspond to the following sources: $\mathrm{C}=\mathrm{Ciesielski}(1983), \mathrm{G}=\mathrm{Gersonde}$ and Burckle (1990), $\mathrm{Ba}=$ Barron (in press), $\mathrm{Bn}=$ Barron (1985b), and B = Baldauf and Barron (1991). 
Table 17. Composite list of Oligocene diatom events and ages from prior studies and by extrapolation from the age-depth plots of Harwood et al. (this volume).

\begin{tabular}{|c|c|c|c|c|c|c|}
\hline Zone & Datum & $\begin{array}{l}\text { Age } \\
(\mathrm{Ma})\end{array}$ & $\begin{array}{c}\text { Published } \\
\text { age }\end{array}$ & $\begin{array}{l}\text { Hole } \\
747 \mathrm{~A} \\
\end{array}$ & $\begin{array}{l}\text { Hole } \\
748 \mathrm{~B}\end{array}$ & $\begin{array}{l}\text { Hole } \\
749 \mathrm{~B} \\
\end{array}$ \\
\hline Rocella gelida c & TR. schraderi & $23.7 \mathrm{C} 6 \mathrm{CN}$ & $22.6 \cdot 22.7 \mathrm{~B}$ & $23.4-23.7$ & 23.7 & \\
\hline Rocella gelida $\mathrm{c}$ & TT. groningensis & 23.7 & & & 23.7 & \\
\hline Racella gelida $b$ & •T L. ornata & 24.5 C6CR-3 & $23.7-25.2$ & $23.4 \cdot 23.7$ & 24.5 & \\
\hline Rocella gelida a & •T R. vigilans var. B & $26.3 \mathrm{C} 7 \mathrm{R}$ & & $26.2-26.3$ & $>25<25.5$ & \\
\hline Rocella gelida a & $T \cdot H$. incisus & $27 \mathrm{C} 7 \mathrm{AR}$ & & $27.8 \cdot 28.1$ & 27 & \\
\hline Rocella gelida a & B T. groningensis & $27.4 \mathrm{C} 8 \mathrm{~N}$ & & & 27.4 & \\
\hline Rocella getida a & B Dactyliozolen & $27.4 \mathrm{C} 8 \mathrm{~N}$ & & & 27.4 & \\
\hline Rocella geitida a & BR. schraderi & $27.4 \mathrm{C} 8 \mathrm{~N}$ & $27.0-27.2$ & 27.4 .27 .7 & $>25<27$ & \\
\hline Rocella gelida a & •B R.gelida & 27.5 & $27.4 \cdot 27.6$ & $27.4-27.7$ & $>25<27$ & \\
\hline L. ornata & TC. hajosiae & $27.8 \mathrm{C} 8 \mathrm{R}$ & & $27.8 \cdot 28.1$ & & $29,4.29 .6$ \\
\hline L. ornata & $T$ Gn et sp. inder. $\# 2$ & $28.8 \cdot 29.2$ & & $28.8 \cdot 29.2$ & & \\
\hline L. ornata & $\tau$ A. punctifera & $29 \mathrm{C} 9 \mathrm{~N}-2$ & & $28.8-29.2$ & 29.7 & $29,8-30.2$ \\
\hline L. ornata & T Rhizosolenia sp. A & $29.3 \mathrm{C} 9 \mathrm{R}-2$ & & & & $29.2-29.4$ \\
\hline L. ornata & •B L. ornata & $29.2 \mathrm{C} 9 \mathrm{R}-2$ & $27.5 \mathrm{~B} 30 \mathrm{H}$ & 29.2 & $>28.4<29.7$ & $29.2-29.4$ \\
\hline A. gombosi & $B R$ vigilans var. $B$ & 29.3 C9R-2 & & $29.2-29.4$ & $>28.4<29.7$ & $29.2-29.4$ \\
\hline A. gambosi & TA. schmidtii & 29.3 & & $29.2 \cdot 29.4$ & 30.2 & \\
\hline A. gombosi & BC. lewisianus & 29.3 & & $29.2-29.4$ & 30.2 & \\
\hline A. gombosi & $T C$. lewis levis & $29.7 \mathrm{C} 10 \mathrm{~N}-1$ & & & 29.7 & \\
\hline A. gombosi & B H. taurus & $29.7 \mathrm{ClON}-1$ & & $29.7 \cdot 30$ & $>28.4<29.7$ & $29,6-29.8$ \\
\hline A. gombosi & $T K$ minor & $29.8 \mathrm{Cl} 10 \mathrm{~N}-1$ & & $29.6-29.8$ & 29.9 & $29.6-29.8$ \\
\hline A. gombosi & B Rhizosolenia sp. A & $29.8 \cdot 30.2$ & & & & $29,8 \cdot 30.2$ \\
\hline A. gombosi & •B A. gombosi & $29.8 \mathrm{CION}-1$ & & $29.4-29.7$ & 29.9 & $29.8-30.2$ \\
\hline R. vigilans $b$ & $B$ Gn et sp. indet. $\# 2$ & $30.1 \mathrm{CION}-2$ & & $29.7-30$ & & \\
\hline R. vigilans $b$ & BA. symmetricus & $30.1 \mathrm{ClON}-2$ & $31.5 \mathrm{H}$ & $29.8-30.2$ & 29.9 & 30.3 \\
\hline R. vigilans $b$ & $T C$. reticulatus & 30 & $31.2+32.2 \mathrm{~B}$ & & 30 & \\
\hline R. vigilans $b$ & B Rhizosolenia sp. A & 30 & & & & $29.8 \cdot 30.2$ \\
\hline R. vigilans b & BC. lewisianus levis & $30 \mathrm{CIOR}-1$ & & & 30.2 & $29.8-30.2$ \\
\hline R. vigilans $b$ & $B C$. rhombicus & $30.2 \mathrm{Cl} 10 \mathrm{~N}-2$ & & $29.8 \cdot 30.2$ & $>30.3<31.2$ & 30.2 \\
\hline R. vigilans a & •T R. vigilans var. A & $30.6 \mathrm{C} 10 \mathrm{R}-2$ & & $>30.4$ & $>30.3<31.2$ & 30.3 \\
\hline$R$. vigilans a & ${ }^{\bullet} \mathbf{B} \mathbf{R}$. vigilans var. A & $32.2 \mathrm{Cl} / \mathrm{R}-2$ & $32 \mathrm{H} 31.7-32.9 \mathrm{~B}$ & $>30.4$ & 32.32 .5 & 32.2 \\
\hline$S$. jouseana & $T P$, reticulata & $32.3 \mathrm{C} 1 \mathrm{IR}-2$ & $32.5 \mathrm{H}$ & & $32.2-32.4$ & $32.2-32.4$ \\
\hline S. jouseana & $T T$. pulchellus & $32.2 \mathrm{C} \| \mathrm{RR}-2$ & & & $32.3-32.5$ & 32.2 \\
\hline S. jouseana & $\bullet$ B S. jouseana & $32.6 \mathrm{Cl} 2 \mathrm{~N}$ & $32.5-32.8 \mathrm{~B} \quad 33 \mathrm{H}$ & & $32.6 \cdot 32.8$ & 32.5 \\
\hline \multicolumn{7}{|l|}{ R. oligocaenica $\mathrm{c}$} \\
\hline R. oligocaenica b & ${ }^{*} \mathrm{~T}$ R. oligocaenica & 33 & $34-34.2 \mathrm{~B} 33 \mathrm{H}$ & & 32.9 & \\
\hline R. oligocaenica b & $T$ Gn et sp. indet. $\# 3$ & 33 & & & 32.9-33.2 & \\
\hline R. oligocaenica b & $T A$. vulgaris hyalinus & $33.4 \mathrm{Cl} 2 \mathrm{R}$ & & & $33.2-33.5$ & \\
\hline R. oligocaenica $b$ & $T N$. udintsevii & 33.5 & & & 33.5 & \\
\hline R. oligocaenica $b$ & $B C$. reticulatus & 35.5 & 35.2 & & 35.5 & \\
\hline R. oligocaenica $b$ & B A, tela & $>32$ & & & & $>32$ \\
\hline R. oligocaenica a & "T T. polymorphus & $34.5 \mathrm{Cl} 12 \mathrm{R}$ & $35.4-35.6 \mathrm{~B}$ & & 34.5 & \\
\hline R. oligocaenica a & BT , primalabiata & 34.7 & & & $34.5-35$ & $>32$ \\
\hline$R$. oligocaenica a & BT bukryi? & $35.5 \mathrm{Cl} 2 / \mathrm{Cl} 13$ & & & $35-35.5$ & 32.5 \\
\hline R. oligocaenica a & $B$ Gnet sp. indet. $\# 3$ & 35.35 .5 & & & $35-35.5$ & \\
\hline \multirow[t]{2}{*}{$R$, oligocaenica a } & •B R. oligocaenica & $35.5 \mathrm{Cl} 3 \mathrm{~N}$ & $35.5 \mathrm{H} 34-34.2 \mathrm{~B}$ & & $35-35.5$ & \\
\hline & TP architecturalis & 36.5 & & & $36.5 \cdot 37$ & \\
\hline
\end{tabular}

Note: Datums that define zone boundaries are in bold; $\mathrm{T}=$ top of range; $\mathrm{B}=$ base of range; $\mathrm{T}^{*} \mathrm{~B}^{*}=$ abundance/consistency datum. Abbreviations in the "Published ages" column correspond to the following sources: $\mathrm{B}=$ Baldauf and Barron (1991) and $\mathrm{H}=$ Harwood et al. (1989a). 
Table 18. New species of diatoms, new combinations, and informal taxonomic names treated in this paper.

New species:

Actinocyclus fasciculatus sp, nov.

Actinocyclus maccollumii sp. nov.

Asteromphalus concavus sp. nov.

Azpeitia gombosi sp. nov.

Denticulopsis hustedtii var. aspera var. nov.

Denticulopsis meridionalis sp. nov.

Navicula wisei sp. nov.

Thalassiosira fasciculata sp. nov.

Thalassiosira oliverana var. sparsa var. nov.

Thalassiosira striata $\mathrm{sp}$. nov.

Thalassiosira webbi sp. nov.

Triceratium polymorphus sp. nov.

New combinations:

Actinocyclus dimorphus comb. nov.

Actinocyclus ingens var. irregularis comb. nov.

Coscinodiscus lewisianus var. levis comb. nov.

Hemidiscus ovalis comb. nov.

Hemidiscus triangularus comb. nov.

Thalassiosira pulchellus (?) comb. nov.

Informal names:

Actinocyclus sp. cf. A. actinochilus (older form)

Actinocyclus ingens var. A

Actinocyclus sp. A

Actinocyclus sp. B

Actinocyclus sp. C

Actinocyclus sp. cf. A. ochotensis

Actinocyclus sp.

Actinoptychus sp.

Asteromphalus sp. A

Cestodiscus sp.

Chaetoceros sp. A

Denticulopsis hustedtii-dimorpha hybrid

Denticulopsis cf. praedimorpha

Dicladia sp.

Genus et species indet. 1 Gombos

Genus et species indet. 1

Genus et species indet. 2

Genus et species indet. 3

Hemiaulus sp. A

Hemidiscus karstenii f. 1 Ciesielski

Hemidiscus sp. 1 of Gersonde and Burckle

Hemidiscus sp. 2 of Gersonde and Burckle

Nitzschia sp. 17 of Schrader

Nitzschia sp. A Harwood et al.

Porosira sp. A

Pterotheca sp.

Rhizosolenia costata var. A

Rhizosolenia sp. A of Harwood

Rhizosolenia sp. A

Rhizosolenia sp. B

Rhizosolenia var. C

Rhizosolenia sp. D

Rocella praenitida? variant.

Rocella vigilans - large form (form $\mathrm{B}$ )

Rocella vigilans - small form (form $\mathrm{A}$ )

Rouxia heteropolara var. A

Rouxia sp. A

Rutilariopsis sp. 1 of Fenner

Synedra sp. 1 and Synedra sp. 2 of Brady

Thalassiosira insigna/inura transitional forms

Thalassiosira striata var.

Thalassiosira sp. A

Thalassiosira sp. B

Thalassiosira sp. C

Xanthiopyxis sp. 1 Hajos 

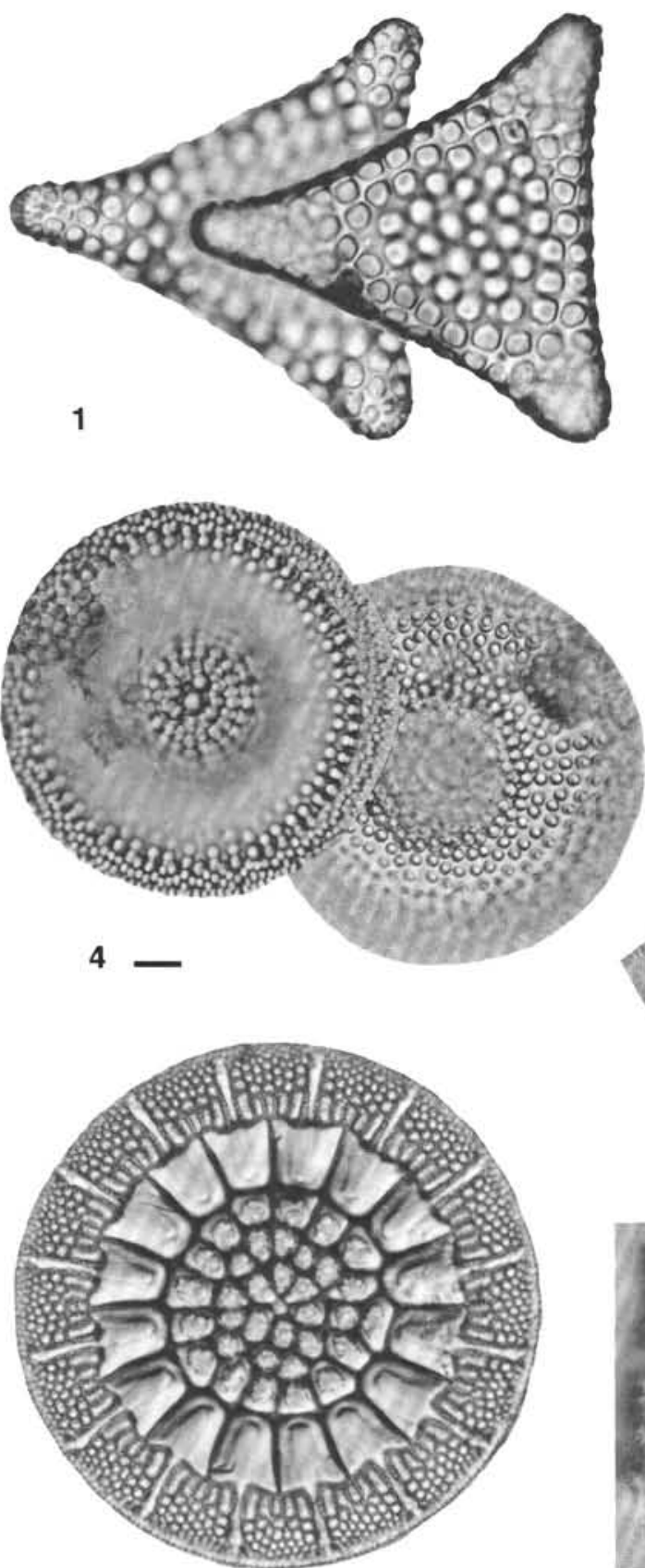

7

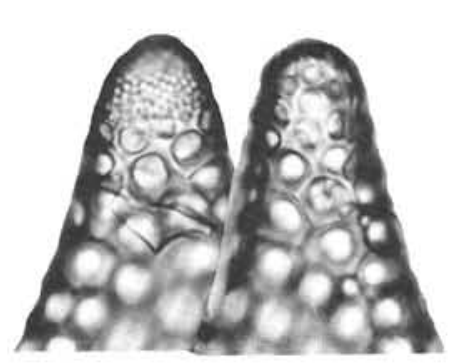

2

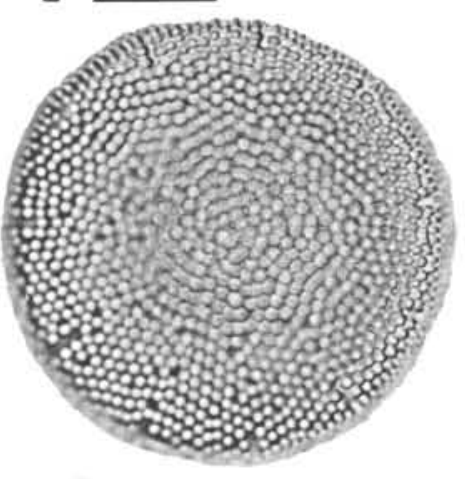

5

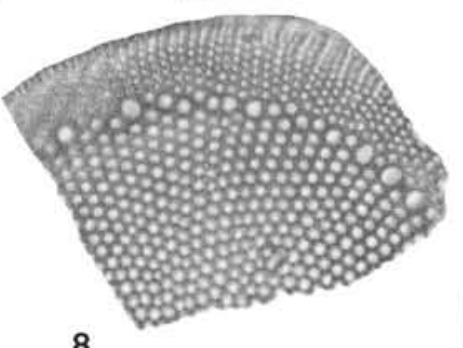

8

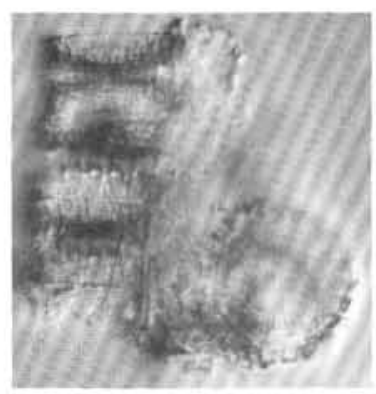

10

6

11

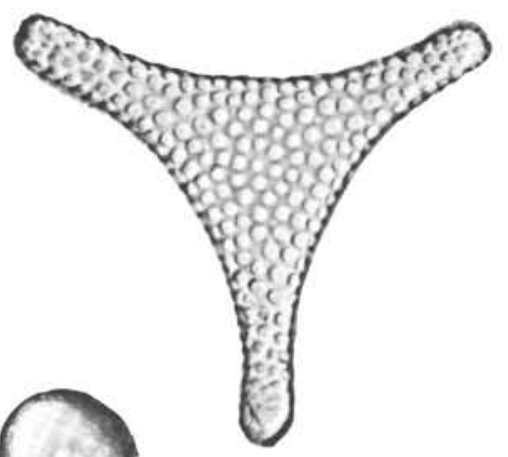

3
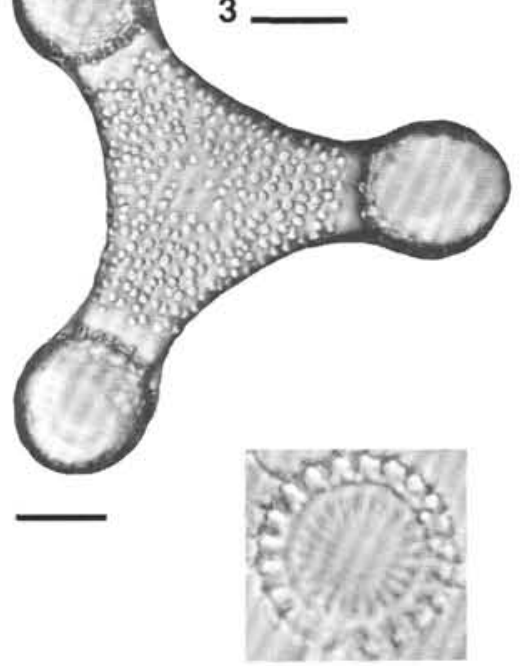

9

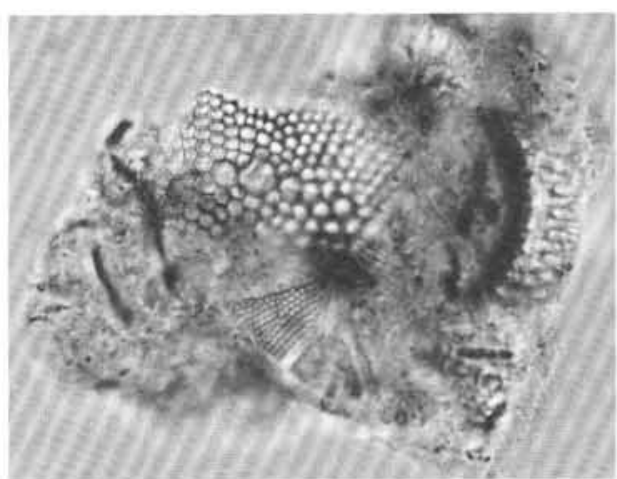

Plate 1. Scale bars equal $10 \mu \mathrm{m}$. 1-3. Triceratium polymorphus n. sp.; (1, 2) Sample 120-748B-14H-1, 116-118 cm; (1) holotype; (2) comparison of different structures at corners of same valve, with pseudocellus shown on left present on only one corner; the other two corners bear a pseudolocular structure like that on the rest of the valve face; (3) Sample 120-748B-13H-CC, paratype. 4. Cestodiscus pulchellus var. novazealandica, Sample 120-748B-14H-1, 52-54 cm. 5. Cestodiscus sp., Sample 120-748B-14H-6, 116-118 cm. 6. Triceratium castelliferum, Sample 120-749B-9H-CC. 7. Asterolampra vulgaris var. cellulosa, Sample 120-749B-17H-4, 116-118 cm. 8. Brightwellia coronata, Sample 120-748B-19H-CC. 9. Paralia sulcata var. crenulata, Sample 120-749B-9H-1, 48-50 cm. 10, 11. Fragments of middle Eocene chert sediment containing abundant Paralia sulcata var. crenulata as the dominant member of the assemblages (Sample 120-748B-19H-CC). Scale bar at bottom center is for all photographs without an individual scale bar. 


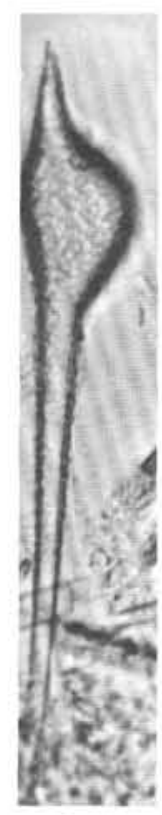

1

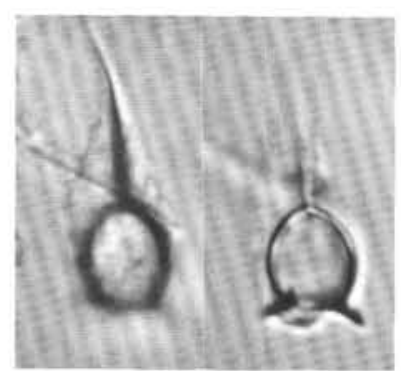

7

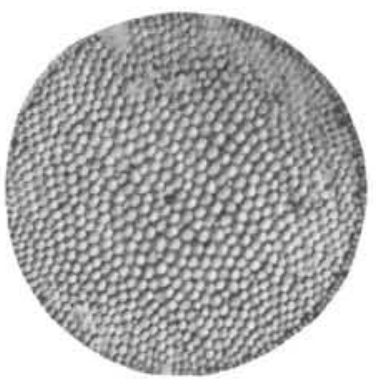

13

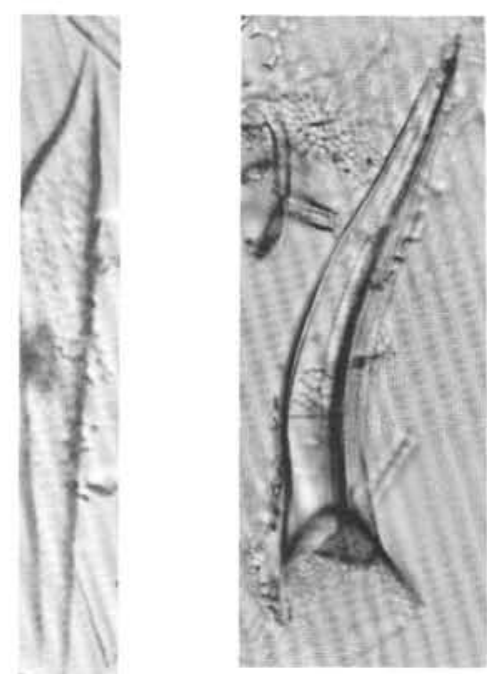

3

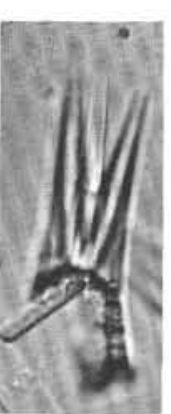

8

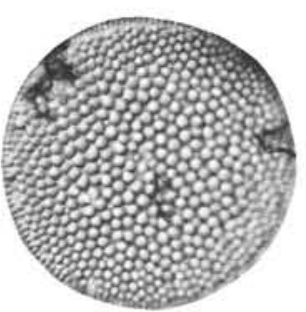

14
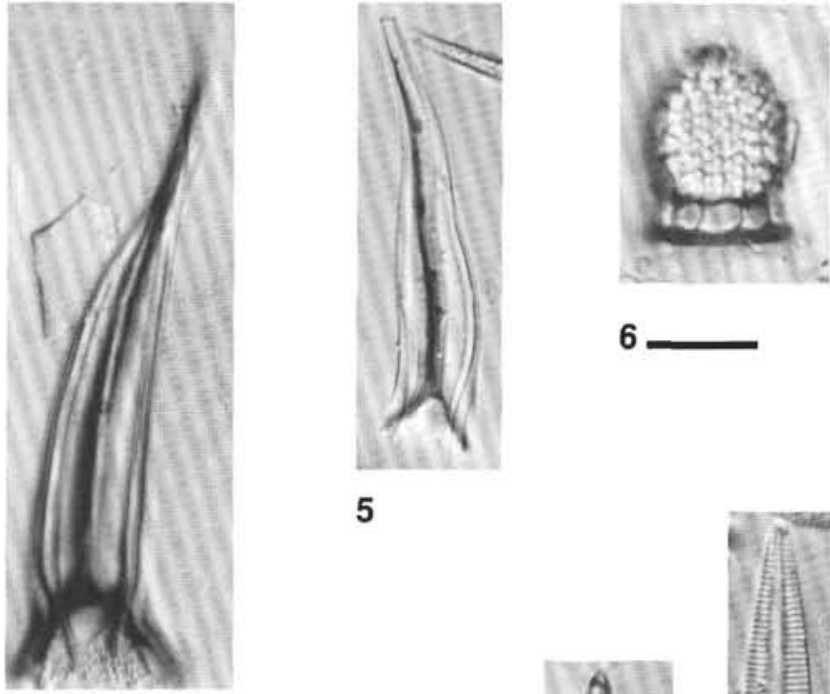

6

5
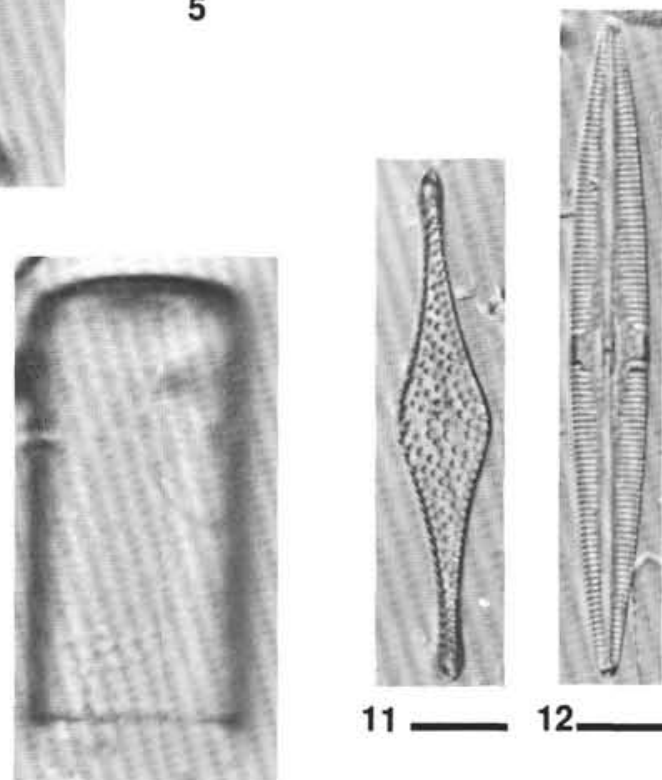

11

12

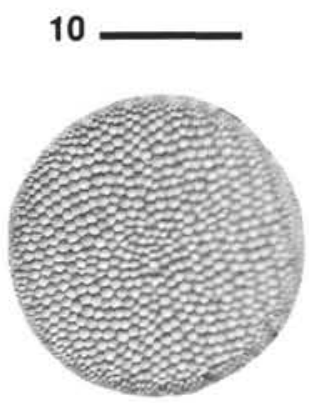

16

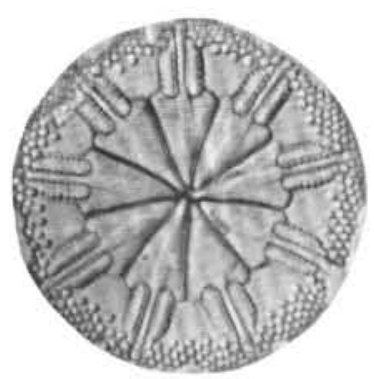

17

Plate 2. Scale bars equal $10 \mu \mathrm{m}$. 1, 2. Genus et species indet. \#2, possibly distal inflations of Chaetoceros setae?; (1) Sample 120-747A-16H-7, 47-49 cm; (2) Sample 120-749B-2H-1, 110-112 cm. 3-5. Genus et species indet. \#3; (3) Sample 120-748B-14H-1, 52-54 cm; (4) Sample 120-748B-13H-5, 116-118 cm; (5) Sample 120-748B-13H-CC. 6. Stephanopyxis ornata, Sample 120-749B-3H-6, 110-112 cm. 7. Pterotheca sp., Sample 120-749B-16H-6, 47-49 cm. 8. Rhizosolenia sp. A, resembles Rhizosolenia hebetata $\mathrm{f}$. bidens but bears three, rather than two, terminal spines (middle spine is slightly out of focus and faint in Fig. 8), Sample 120-749B-2H-1, 110-112 cm. 9, 10. Pseudopyxilla baltica; note interior "valve" in lower quarter of Figure 9, resembling the hypovalve of Calyptosporium, Sample 120-747A-16H-6, 47-49 cm. 11. Baxteriopsis brunii, Sample 120-749B-2H-6, 47-49 cm. 12. Navicula udintsevii, Sample 120-748B-13H-4, 116-118 cm. 13-16. Thalassiosira bukryi ?; (13-15) Sample 120-748B-12H-5, 47-49 cm; (16) Sample 120-748B-14H-1, 52-54 cm. 17. Asterolampra vulgaris var. hyalina, Sample 120-748B-13H-6, 116-118 $\mathrm{cm}$. Scale bar at bottom center is for all photographs without an individual scale bar. 


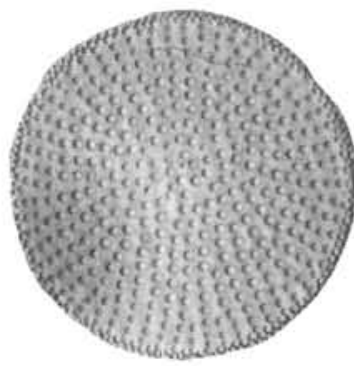

1

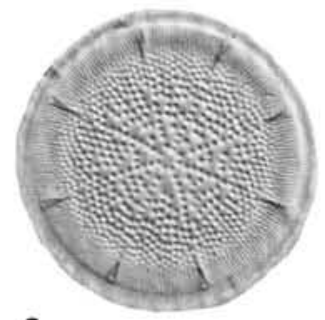

6

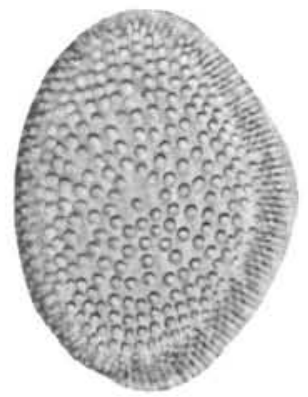

10

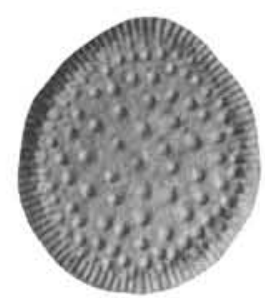

13

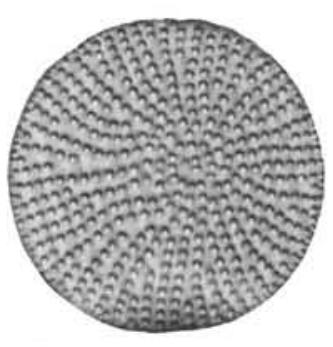

2

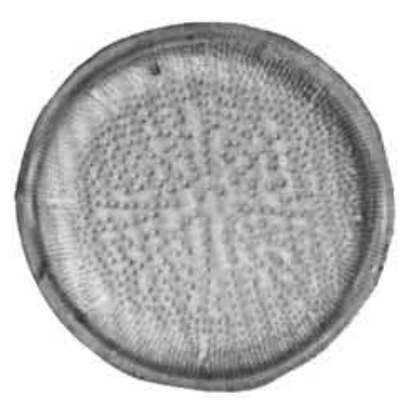

7

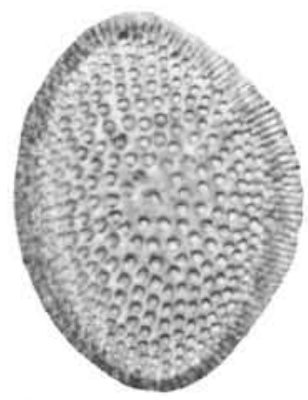

11

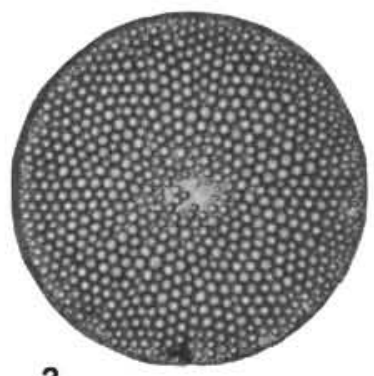

3

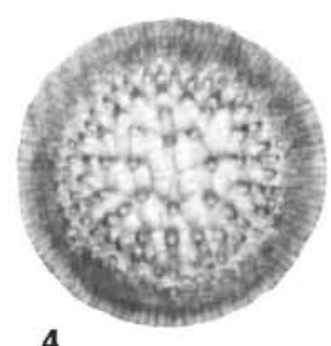

4
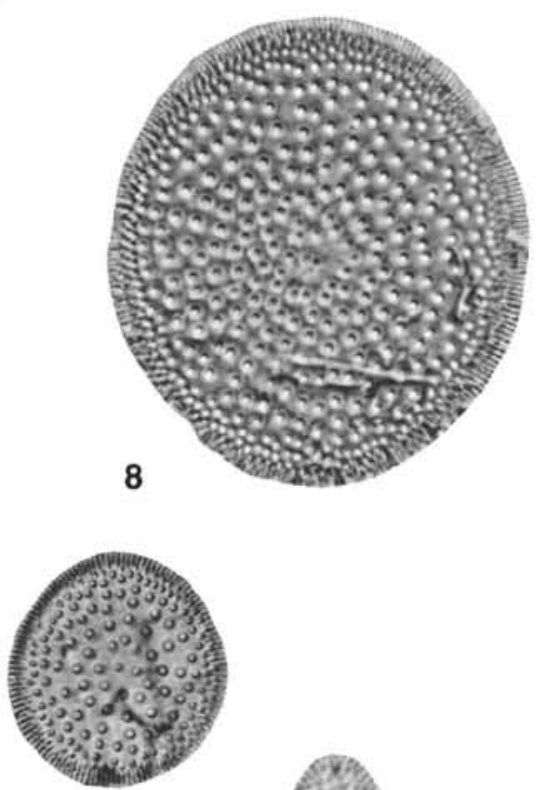

12

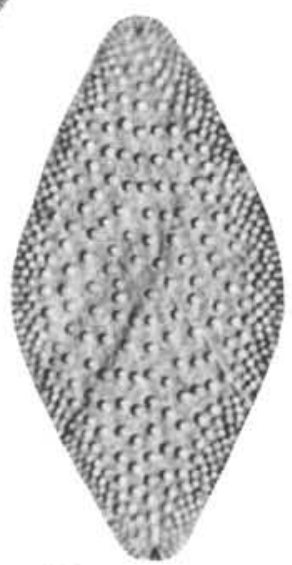

16

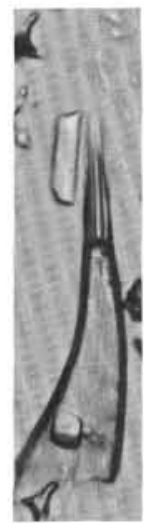

5

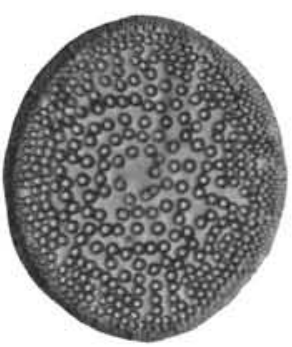

9

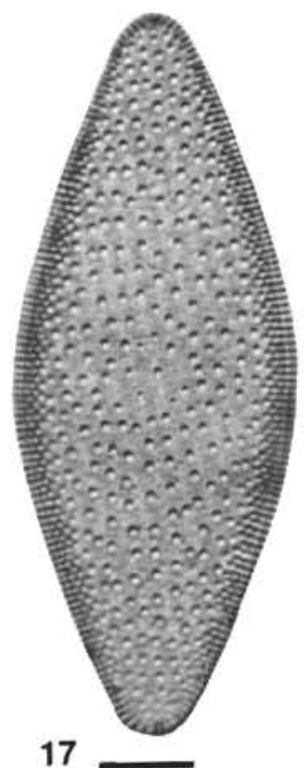

Plate 3. Scale bars equal $10 \mu \mathrm{m}$. 1, 2. Azpeitia gombosi n. sp. (1) Sample 120-747A-16H-7, 47-49 cm, holotype; (2) Sample 120-748B-10H-3, 47-49 $\mathrm{cm}$, paratype. 3. Azpeitia oligocenica, Sample 120-748B-12H-3, 47-49 cm. 4. Cestodiscus reticulatus, Sample 120-748B-11H-7, 47-49 cm. 5. Rhizosolenia oligocaenica, Sample 120-748B-12H-3, 47-49 cm. 6, 7. Cestodiscus pulchellus?; (6) Sample 120-748B-10H-4, 46-49 cm; (7) Sample 120-747A-16H-6, 47-49 cm. 8, 9. Coscinodiscus lewisianus var. robustus; note the raised left margin of the specimens in both figures and the expanded right margin, features that suggest an affinity with species of Kozloviella; (8) Sample 120-748B-10H-6, 47-49 cm; (9) Sample 120-748B-11H-2, 47-49 cm. 10, 11. Kozloviella minor; (10) Sample 120-749B-2H-4, 110-112; (11) Sample 120-749B-11H-2, 47-49 cm. 12-15. Coscinodiscus lewisianus var. levis $\mathrm{n}$. comb.; note the raised left edge of specimens in the figures, a feature resembling Kozloviella; (12) Sample 120-748B-10H-6, 47-49 cm; (13) Sample 120-747A-17H-4, 47-49 cm; (14) Sample 120-747A-17H-3, 47-49 cm; (15) Sample 120-748B-10H-CC. 16, 17. Coscinodiscus rhombicus, Sample $120-747 \mathrm{~A}-17 \mathrm{H}-4,47-49 \mathrm{~cm}$. Scale bar at bottom center is for all photographs without an individual scale bar. 


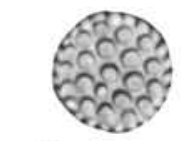

1

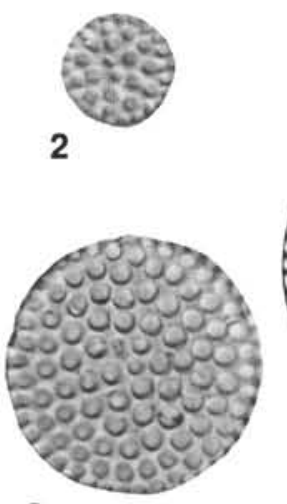

8

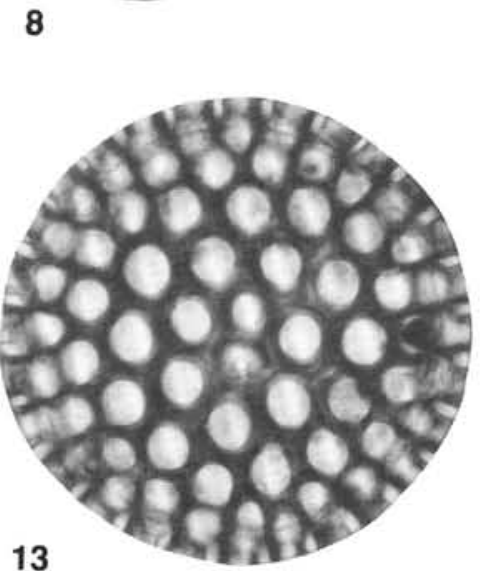

13

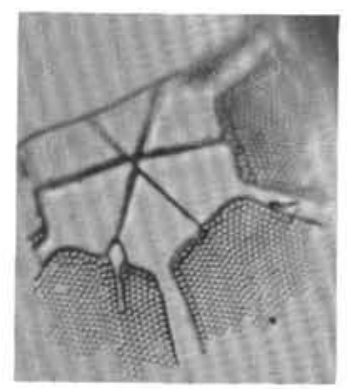

16

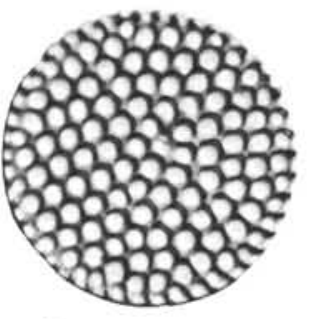

9

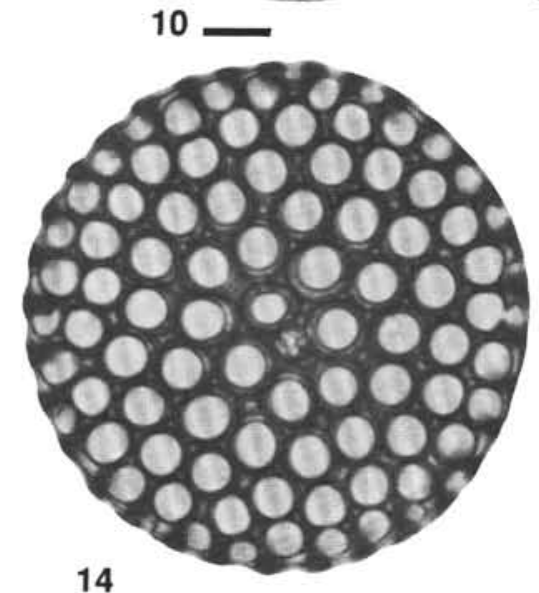

11
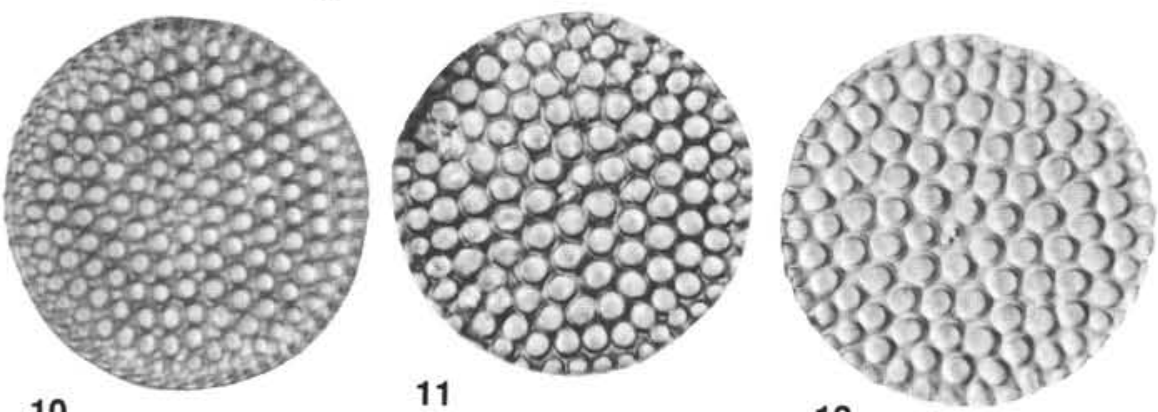

12
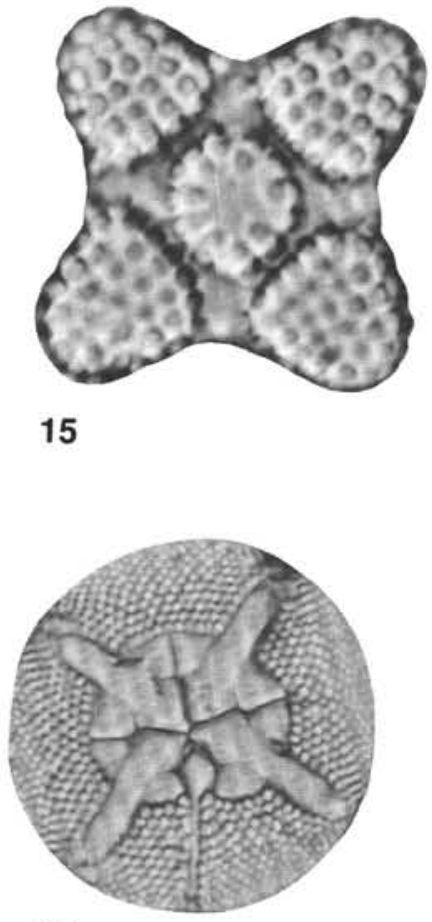

18

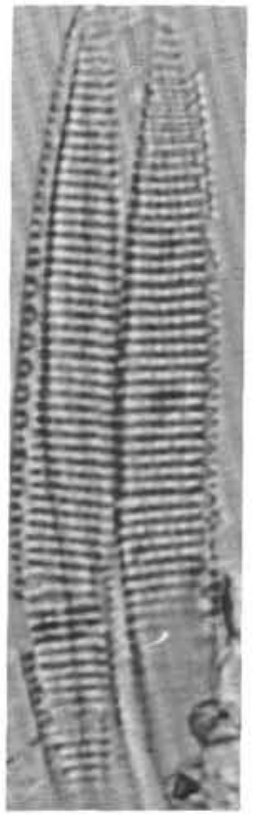

19

Plate 4. Scale bars equal $10 \mu \mathrm{m}$. 1-5. Rocella praenitida; (1) Sample 120-748B-12H-2, 47-49 cm; (2, 3) Sample 120-749B-2H-6, 110-112 cm; (4) Rocella praenitida?, Sample 120-747A-16H-7, 47-49 cm; (5) Sample 120-749B-2H-CC. 6, 7. Rocella semigelida?, Sample 120-749B-2H-3, 110-112 cm. 8-12. Rocella vigilans var. A; (8) Sample 120-749B-2H-4, 110-112 cm; (9) Sample 120-748B-11H-4, 47-49 cm; (10) Sample 120-748B-12H-1, 47-49 cm; (11) Sample 120-749B-2H-4, 47-49; (12) Sample 120-2H-5, 110-112 cm. 13, 14. Rocella vigilans var. B; (13) Sample 120-747A-14H-1, 47-49 cm; (14) Sample 120-747A-16H-3, 47-49 cm. 15. Lisitzinia ornata, Sample 120-747A-16H-6, 47-49 cm. 16. Asterolampra tela (form transitional to Asteromphalus? - not undeveloped "vestigial" primary ray), Sample 120-748B-11H-3, 47-49 cm. 17. Asteromphalus oligocenicus, Sample 120-748B-11H-3, 47-49 cm. 18. Asteromphalus symmetricus, Sample 120-748B-6H-2, 47-49 cm. 19. Nitzschia evenescens, Sample 120-747A-14H-3, 47-49 cm. Scale bar at bottom center is for all photographs without an individual scale bar. 


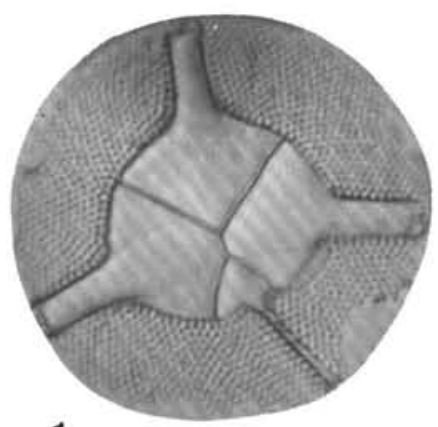

1

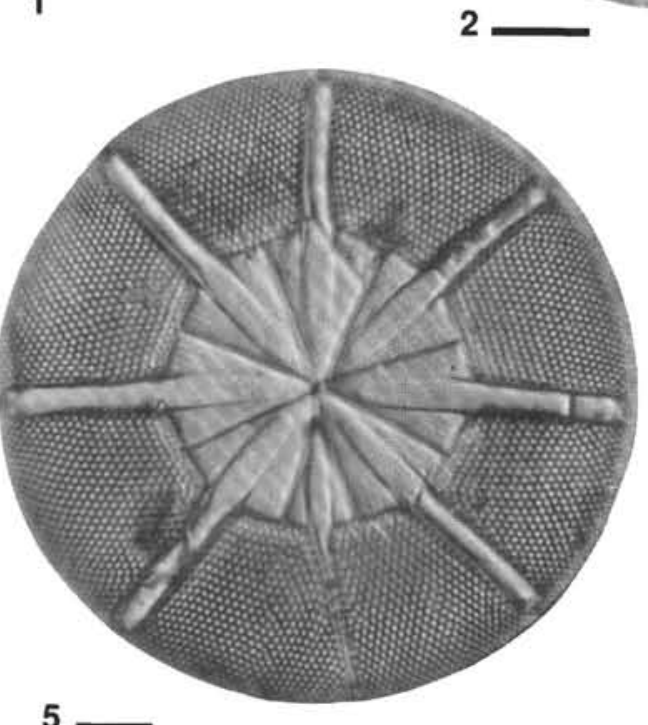

5

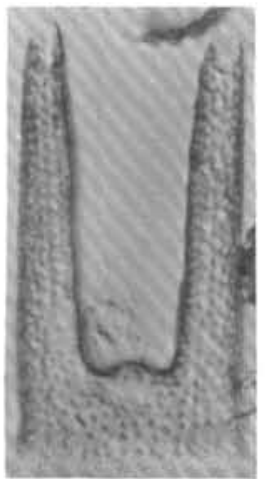

11
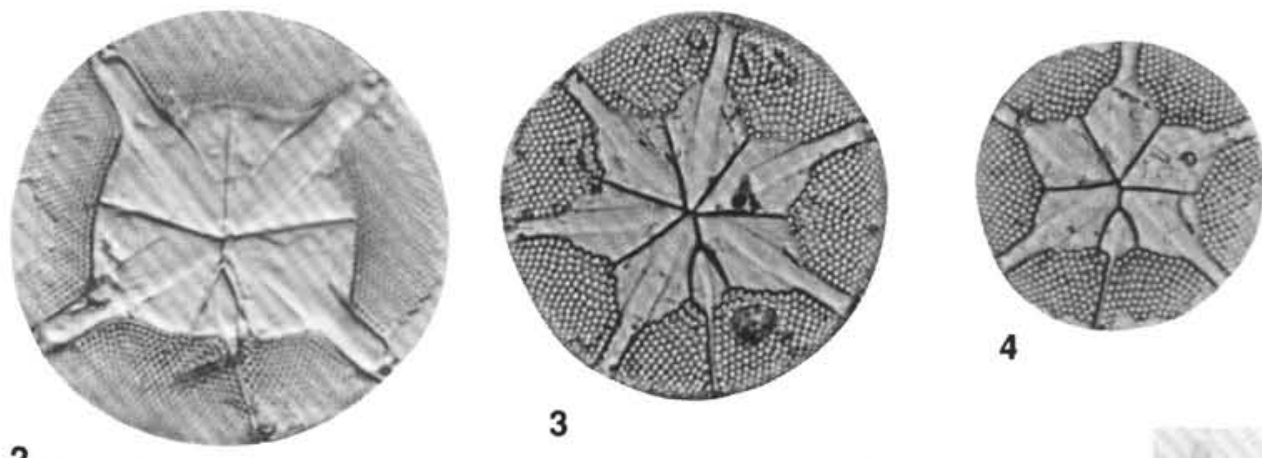

3
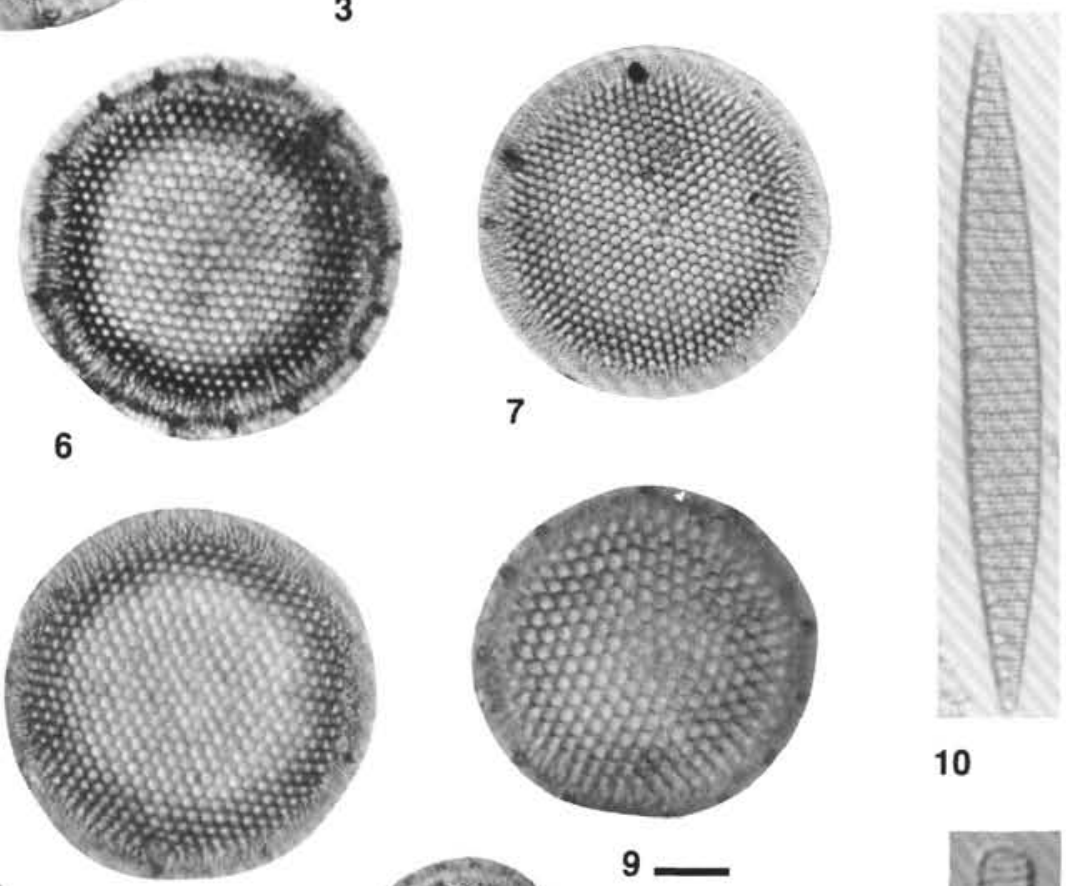

10

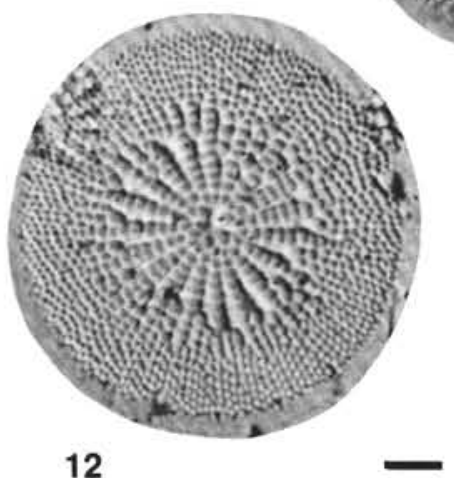

8

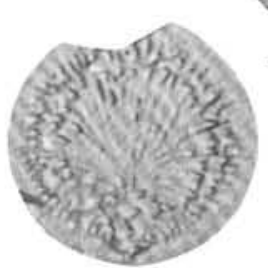

13

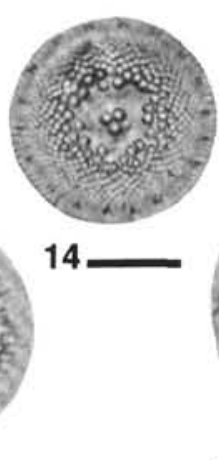

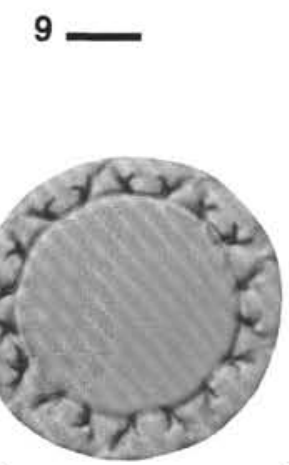

15

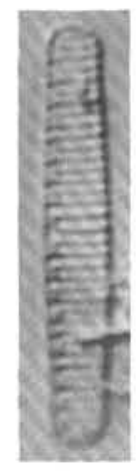

16

Plate 5. Scale bars equal $10 \mu \mathrm{m}$. 1, 2. Asteromphalus inaequabilis, Sample 120-748B-6H-2, $47-49$ cm. 3, 4. Asteromphalus sp. A, Sample 120-748B-5H-4, 72-76 cm. 5. Asteromphalus oligocenicus, Sample 120-748B-6H-2, 47-49 cm. 6-9. Thalassiosira praelineata; (6, 8) Sample 120-747A-5H-4, 72-76 cm; (7) Sample 120-747A-5H-5, 47-49 cm; (9) Sample 120-748B-3H-3, 47-49 cm. 10. Denticula norwegia, Sample 120-748B-6H-2, 47-49 cm. 11. Hemiaulus sp. A, Sample 120-748B-6H-1, 47-49 cm. 12. Actinocyclus sp. A, Sample 120-747A-4H-6, 47-49 cm. 13. Genus et sp. indet. \#1, Sample 120-748B-6H-2, $47-49 \mathrm{~cm}$. 14. Thalassiosira inura (upper Miocene specimen), Sample 120-747A-4H-3, 48-50 cm. 15. Corethron criophilum, Sample 120-748B-3H-3, 47-49 cm. 16. Nitzschia sp. A, Harwood et al. (1989), Sample 120-748B-7H-1, 47-48 cm. Scale bar at bottom center is for all photographs without an individual scale bar. 


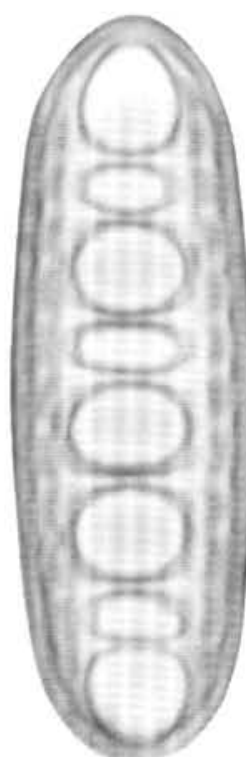

1

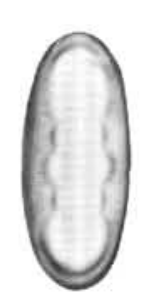

8

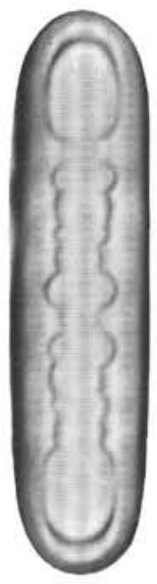

14

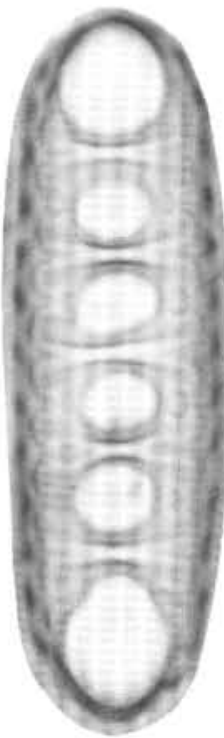

2

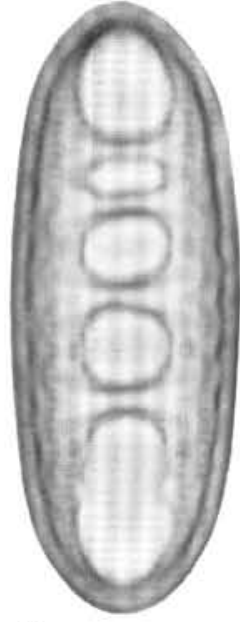

3

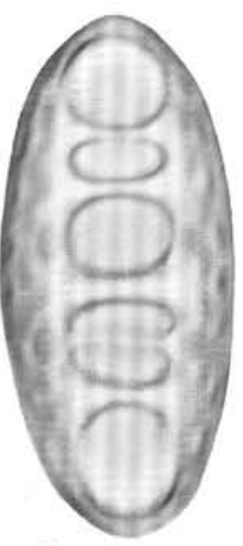

4
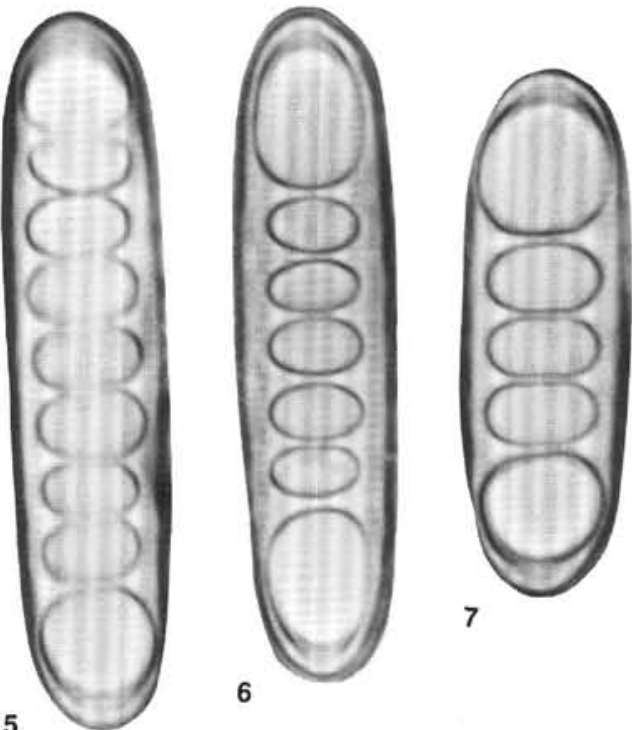

7

6

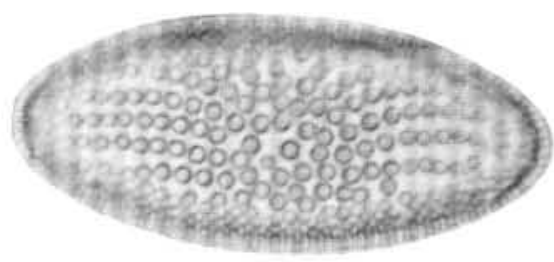

13

12

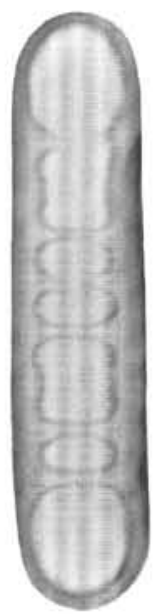

18

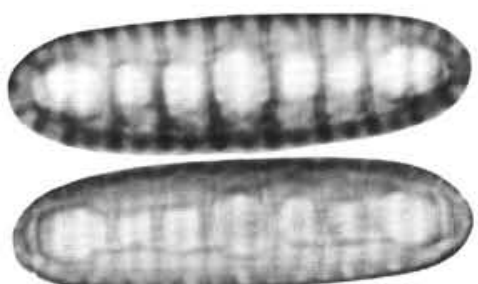

11

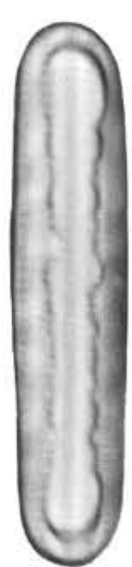

15
10

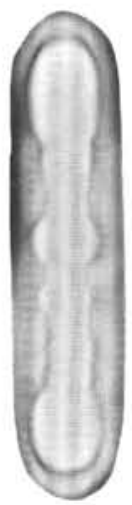

16

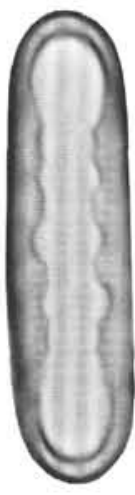

17

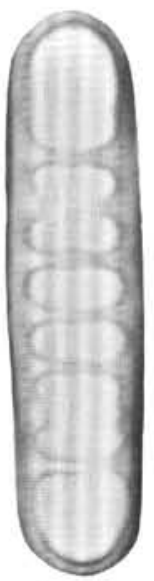

19

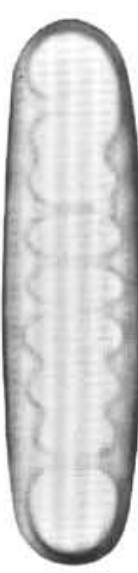

20

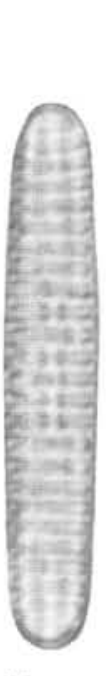

21

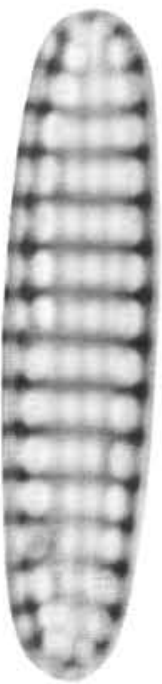

22

Plate 6. Scale bars equal $10 \mu \mathrm{m}$. 1-4. Denticulopsis meridionalis n. sp., copula, Sample 120-751A-9H-3, 105-106 cm. 5-7. Denticulopsis dimorpha, copula, Sample 120-751A-11H-6, 105-107 cm. 8-10, 12, 14-17. Denticulopsis praedimorpha, Sample 120-751A-11H-6, 105-107 cm; (8-10, 14-17) copula; (12) external view of theca. 11, 18-20. Denticulopsis cf. praedimorpha, copula, Sample 120-751A-11H-1, 105-107 cm. 13. Coscinodiscus lewisianus, external view of valve, Sample 120-751A-14H-6, 112-115 cm. 21. Nitzschia maleinterpretaria, external view of valve, Sample 120-751A-16H-6, 105-107 cm. 22. Denticulopsis maccollumii, external view of valve, Sample 120-751A-14H-6, 112-115 cm. Scale bar at bottom center is for all photographs without an individual scale bar. 


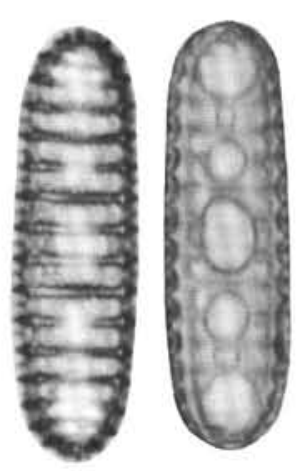

1

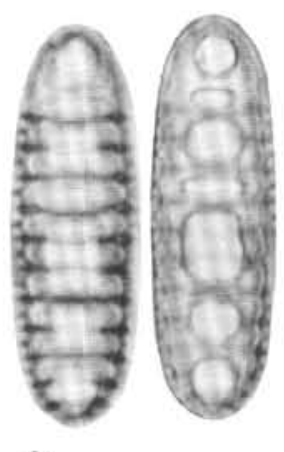

2

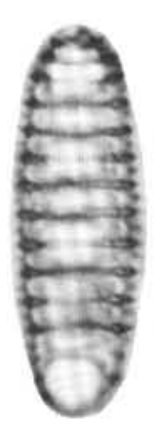

3

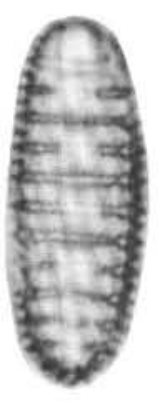

4
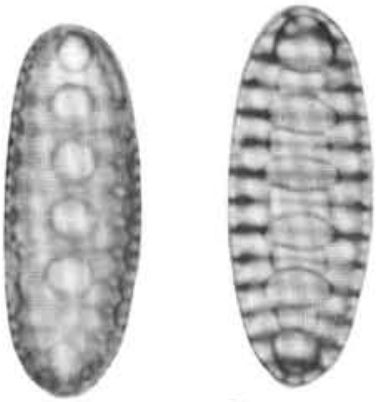

5

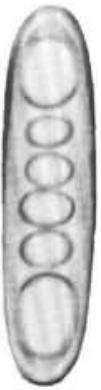

10
6

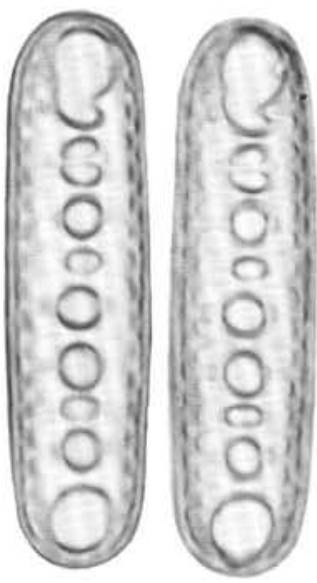

11

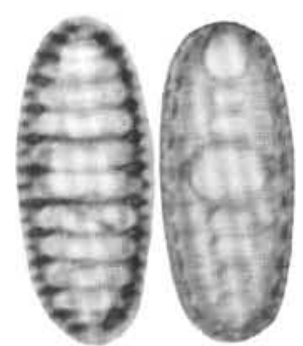

7

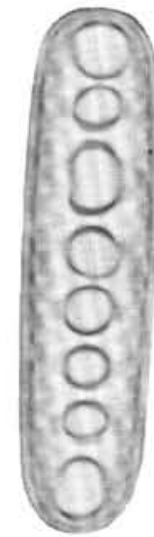

12

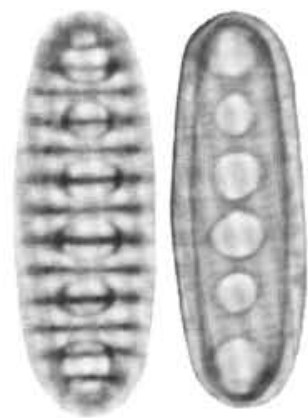

8

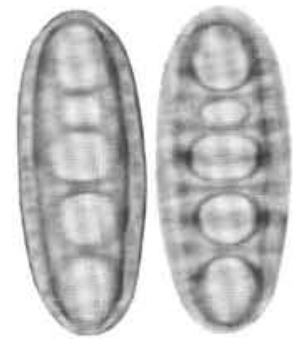

9

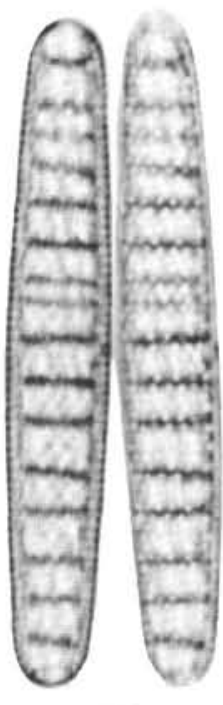

15

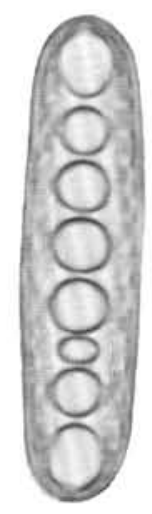

13

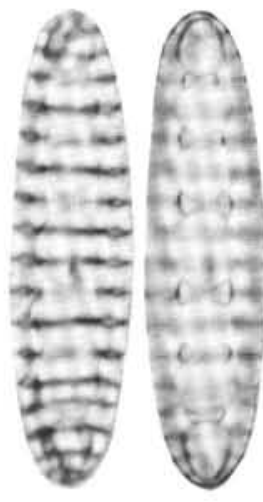

14

Plate 7. Scale bar equals $10 \mu \mathrm{m} .1-4,6-9,11-13$. Denticulopsis meridionalis n. sp., Sample 120-751A-9H-4, 105-106 cm; (1) Holotype; (1-4, 6, 7) external view of theca; (8-9) internal view of theca; (11-13) copula. 5. Denticulopsis hustedtii var. ovata, internal view of valve with deck, Sample 120-751A-6H-5, 105-106 cm. 10. Denticulopsis dimorpha, copula, Sample 120-751A-11H-6, 105-107 cm. 14. Denticulopsis hustedtii, internal view of valve with deck, Sample 120-751A-6H-5, 105-106 cm. 15. Crucidenticula kanayae, external view of valve, Sample 120-751A-16H-6, 105-107 cm. 16. Nitzschia sp. 17, external view of valve, Sample 120-751A-14H-6, 112-115 cm. 17. Denticulopsis maccollumii, external view of valve, Sample 120-751A-14H-6, 112-115 cm. 

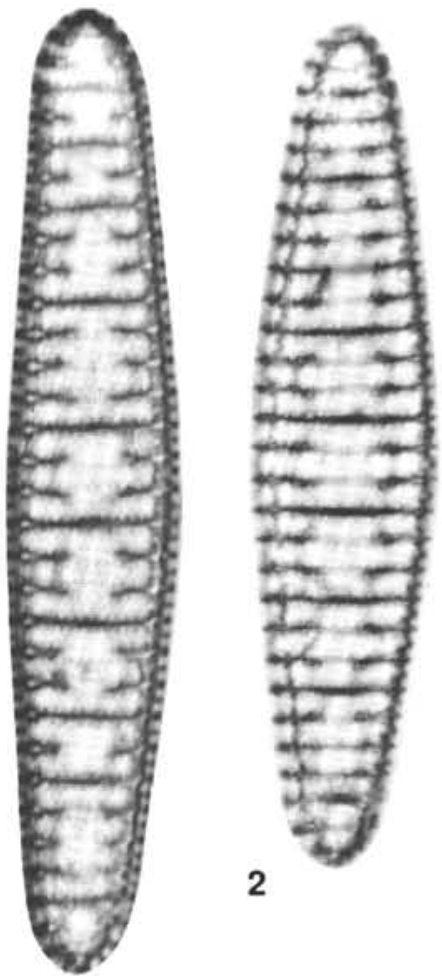

1

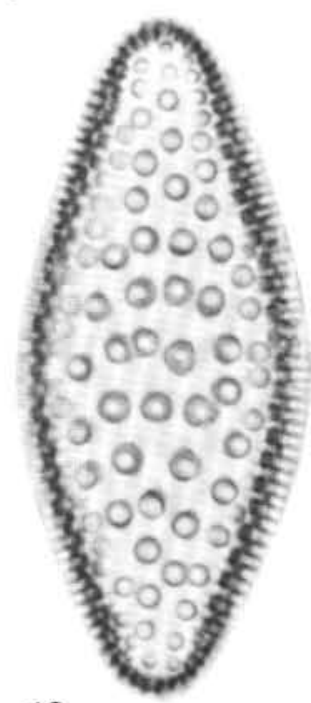

12

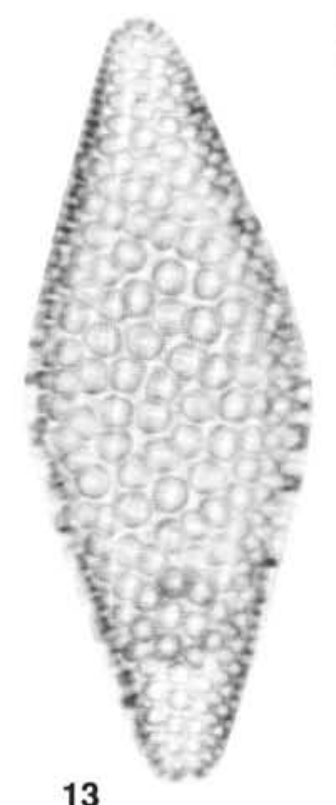

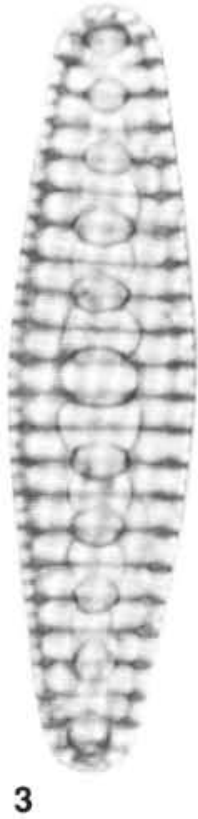

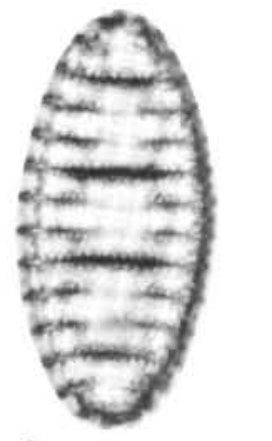

9

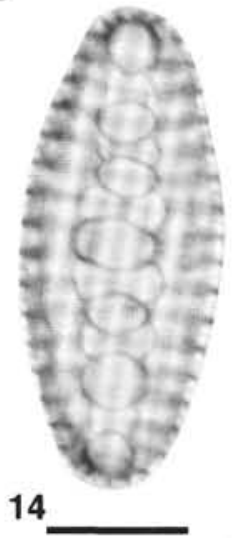

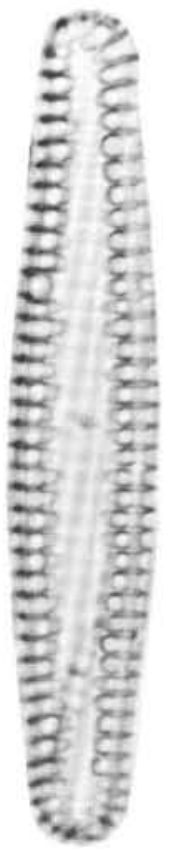

5
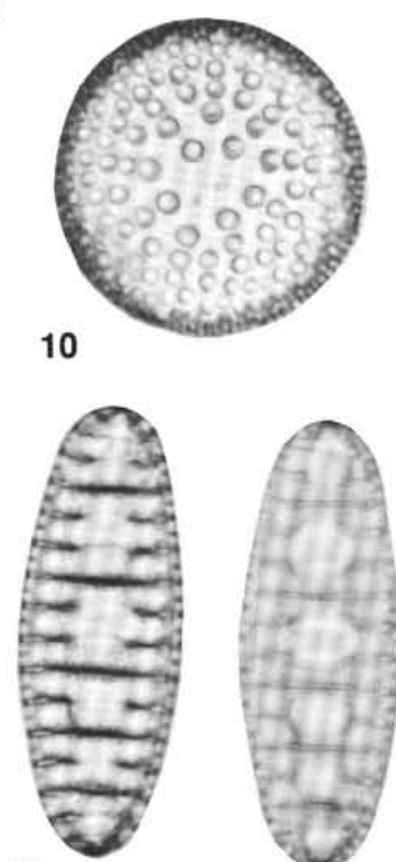

15
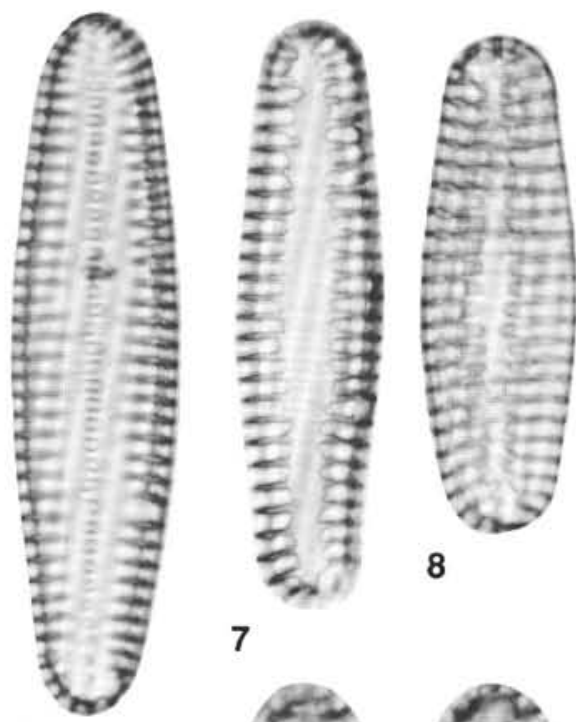

8

7

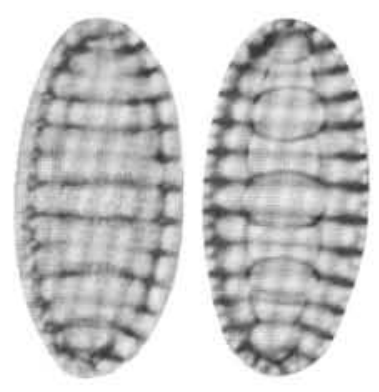

11

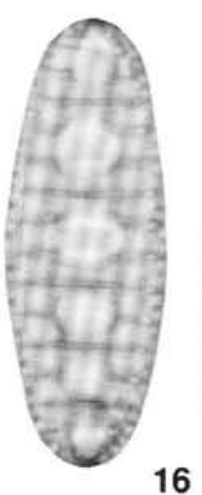

Plate 8. Scale bars equal $10 \mu \mathrm{m} .1-3,16$. Denticulopsis hustedtii; $(1,2)$ external view of valve; $(3,16)$ internal view of valve with deck; $(1-3)$ Sample 120-751A-6H-5, 105-106 cm; (16) Sample 120-751A-9H-4, 105-106 cm. 4, 9, 11, 14, 15. Denticulopsis hustedtii var. ovata; (4, 9) external view of valve; $(11,14)$ internal view of valve with deck; (15) external view of valve with deck; $(4,9,11,14)$ Sample $120-751 \mathrm{~A}-6 \mathrm{H}-5,105-106 \mathrm{~cm}$; (15) Sample 120-751A-6H-4, 105-106 cm. 5-8, 17. Nitzschia denticuloides; (5-8) external view of valve; (17) copula; (5, 7, 8, 17) Sample 120-751A-11H-6, 105-107 cm; (6) Sample 120-751A-11H-1, 105-107 cm. 10. Actinocyclus ingens, external view of valve, Sample 120-751A$11 \mathrm{H}-6,105-107 \mathrm{~cm}$. 12, 13. Coscinodiscus rhombicus, external view of valve, Sample 120-751A-17H-2, 105-107 cm. Scale bar at bottom center is for all photographs without an individual scale bar. 


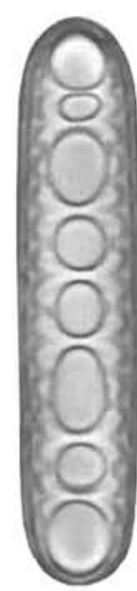

1

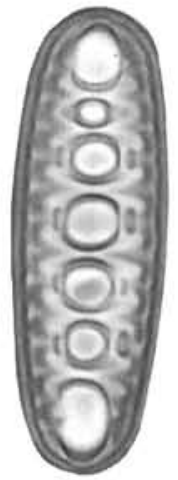

10

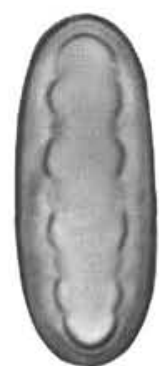

19

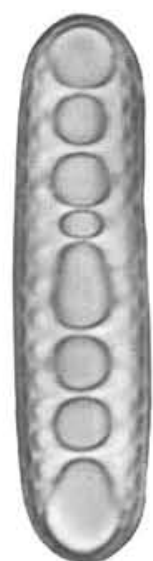

2

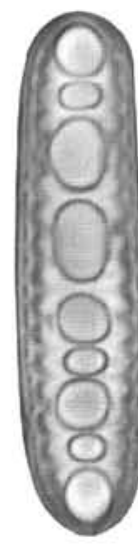

3

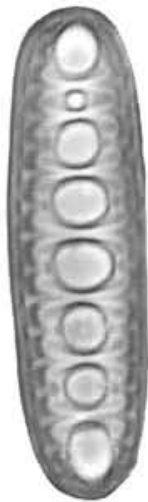

4

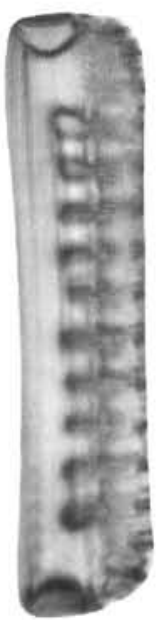

5

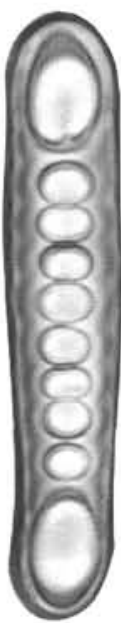

6

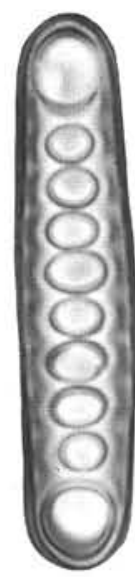

7

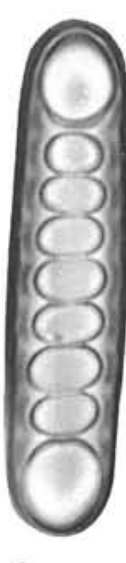

8

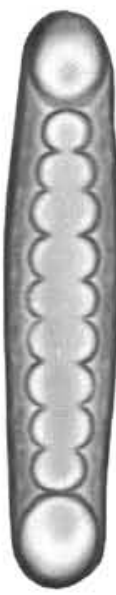

9

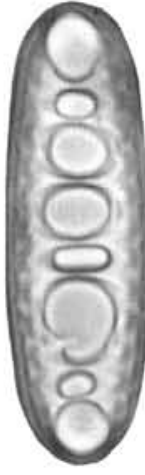

11

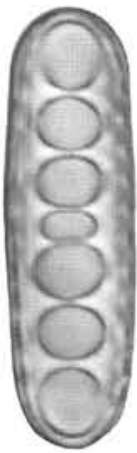

12

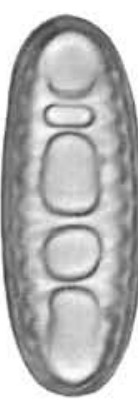

13

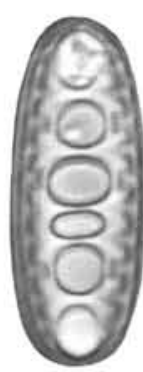

14

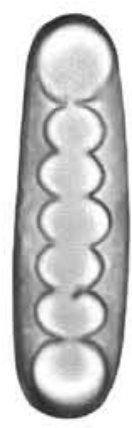

15

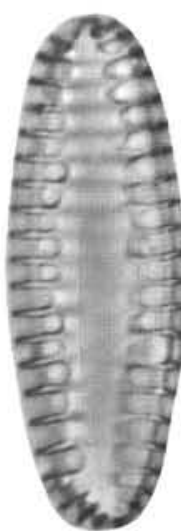

24

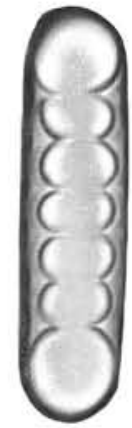

16
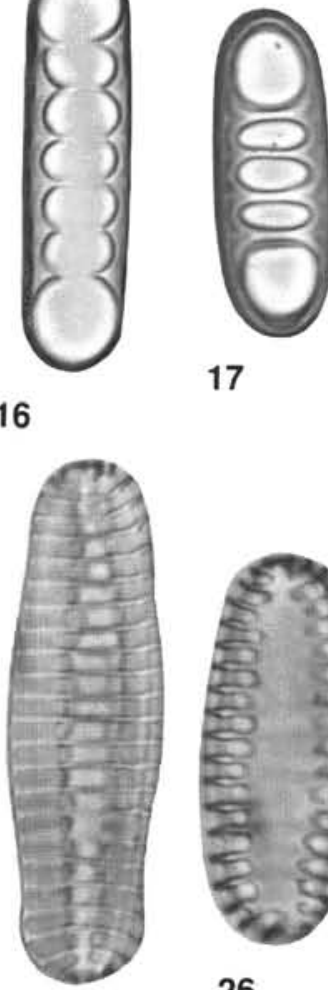

25
17

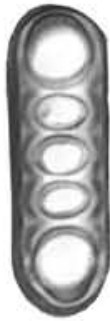

18

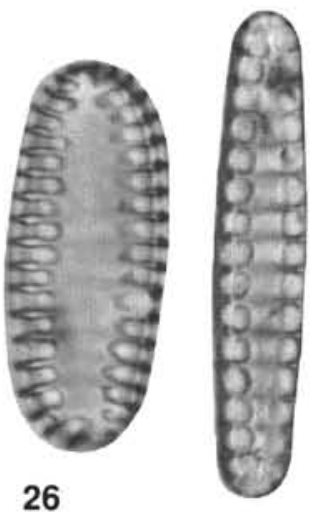

27

Plate 9. Scale bar equals $10 \mu \mathrm{m} .1-4,10-14$. Denticulopsis meridionalis $\mathrm{n}$. sp., copula, Sample 120-751A-9H-4, 105-106 cm. 5-9, 15-18, 22, 23. Denticulopsis dimorpha; (5) girdle view of theca; $(6,7,8,17,18)$ copula; $(9,15,16)$ copula (spiny type); (22) external view of valve; $(23)$ copula (open band), Sample 120-751A-9H-4, 105-106 cm. 19-21. Denticulopsis hustedtii; $(19,20)$ copula (closed band), Sample 120-751A-7H-1, 105-106 $\mathrm{cm}$; (21) internal view of valve with deck, Sample 120-751A-9H-4, 105-106 cm. 24-26. Nitzschia denticuloides, external view of valve, Sample 120-751A-12H-2, 105-107 cm. 27. Denticulopsis maccollumii, external view of valve, Sample 120-751A-14H-3, 105-107 cm. 


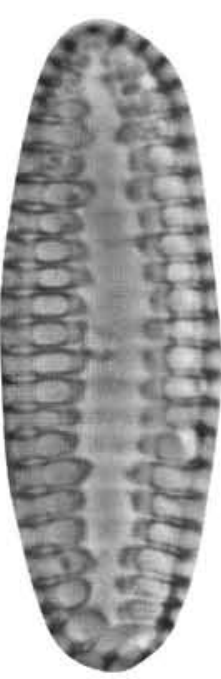

1

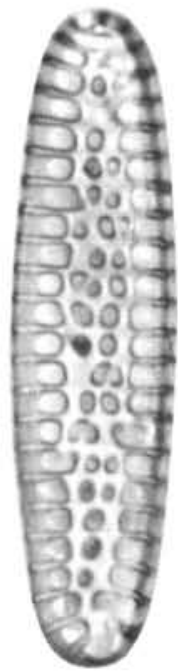

2

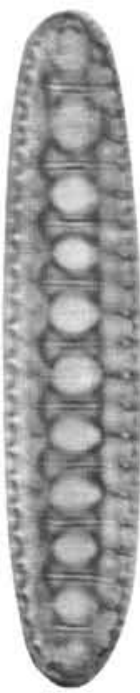

3

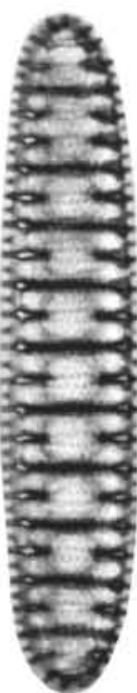

4
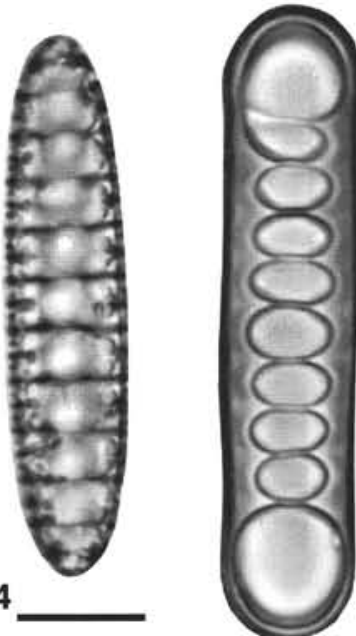

5

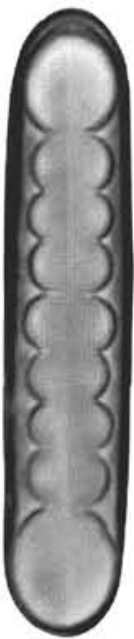

7

6

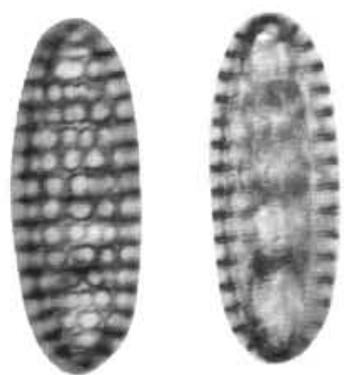

8

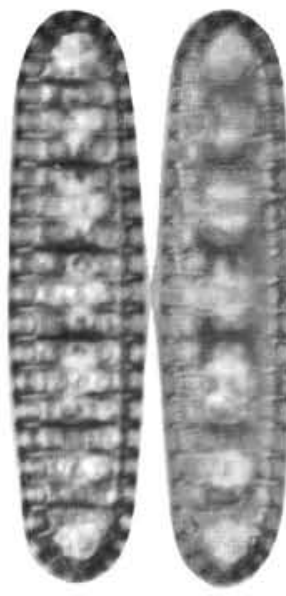

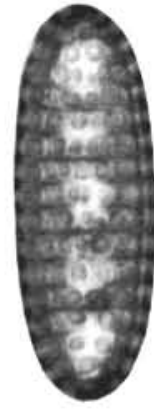

10

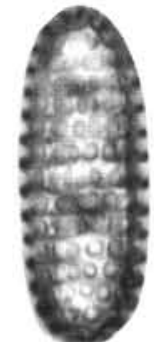

11

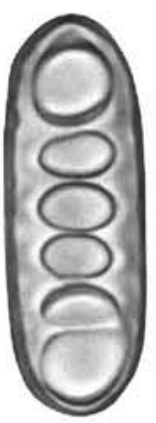

12

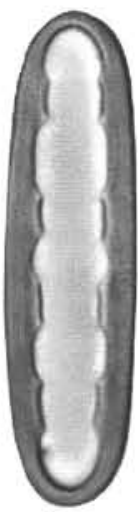

13

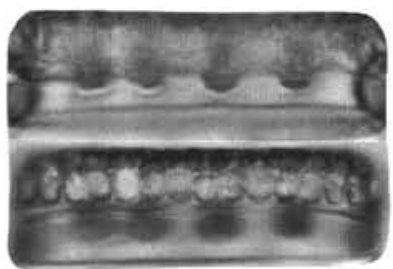

17

14

15

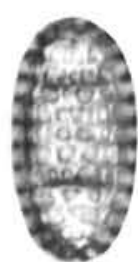

16

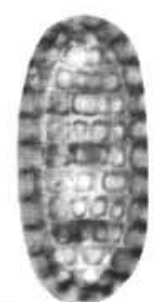

Plate 10. Scale bars equal $10 \mu \mathrm{m}$. 1. Nitzschia denticuloides, external view of valve, Sample 120-748B-5H-7, 47-48 cm. 2. Nitzschia grossepunctata, external view of valve, Sample 120-751A-12H-6, 105-107 cm. 3, 13. Denticulopsis hustedtii; (3) external view of valve with deck, Sample 120-751A-12H-6, 105-107 cm; (13) copula (closed band), Sample 120-751A-7H-1, 105-106 cm. 4. Denticulopsis hyalina, external view of valve, Sample 120-751A-12H-6, $105-107 \mathrm{~cm} . \mathbf{5}, \mathbf{6}, \mathbf{1 2}$. Denticulopsis dimorpha, copula; $(5,12)$ normal type; $(6)$ spiny type; $(5,6,12)$ Sample 120-748B-5H-5, 47-48 cm. 7. Denticulopsis meridionalis n. sp., copula, Sample 120-748B-4H-5, 47-48 cm. 8- 11, 15, 16. Denticulopsis hustedtii var. aspera var. nov.; $(8,9)$ external view of valve with deck; $(10,11,15,16)$ external view of valve, holotype; Sample 120-751A-7H-1, $105-106 \mathrm{~cm}$. 14. Denticulopsis dimorpha, girdle view of theca, Sample 120-751A-9H-4, 105-106 cm. 17. Denticulopsis cf. hustedtii, girdle view of theca with closed band, Sample 120-751A-7H-1, 105-106 cm. Scale bar at bottom center is for all photographs without an individual scale bar. 

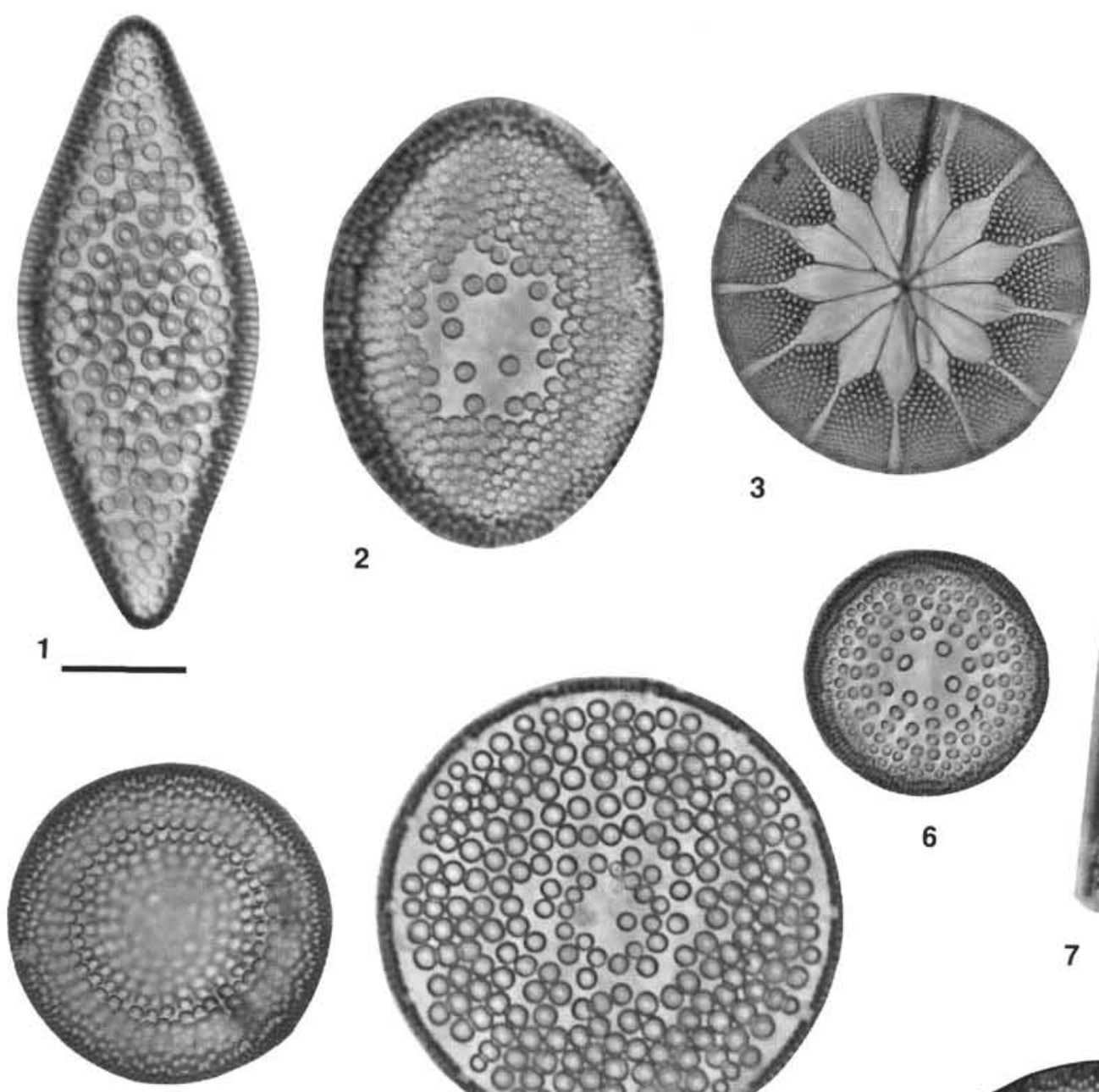

4

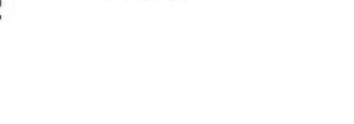

\section{(}
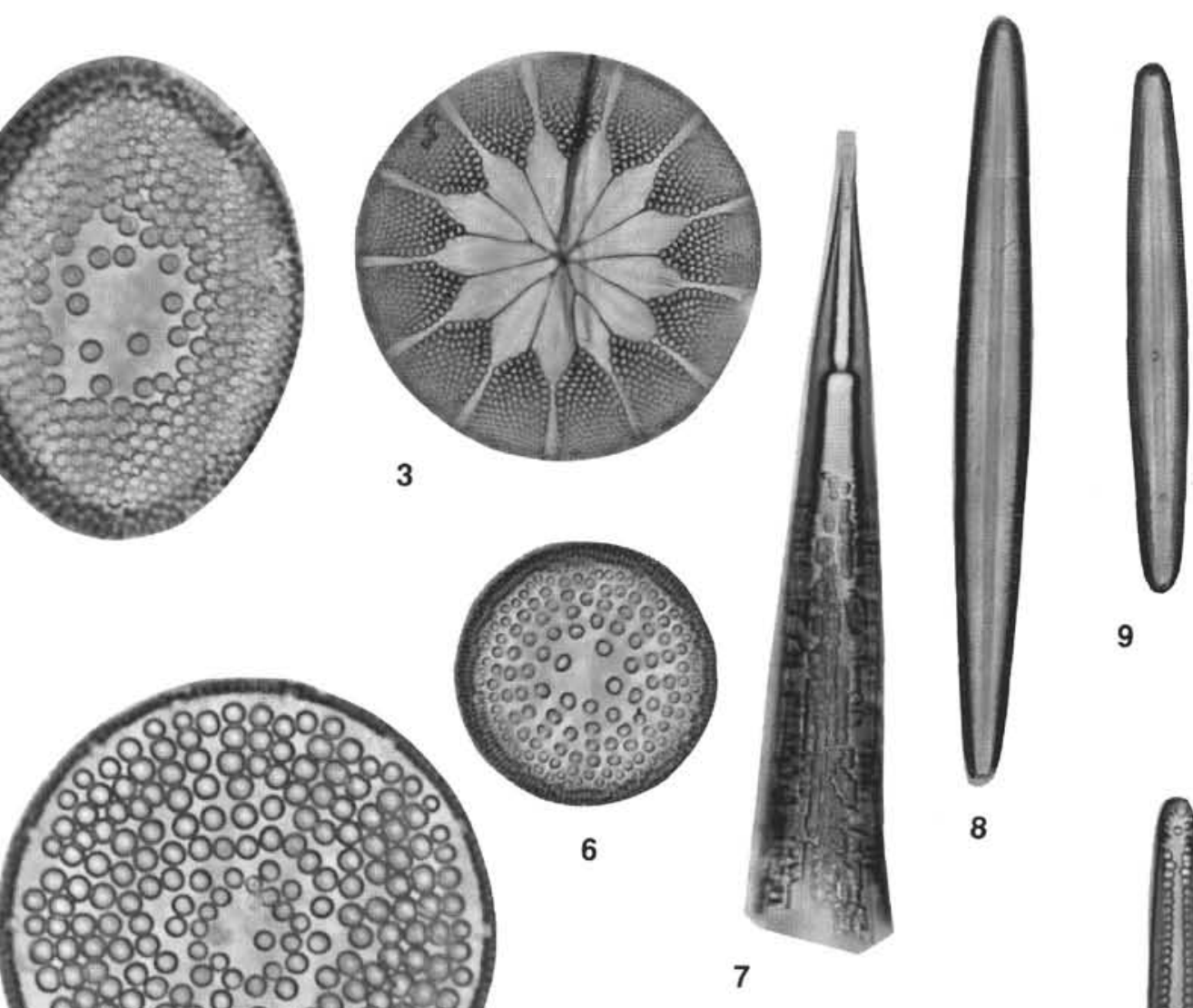

9

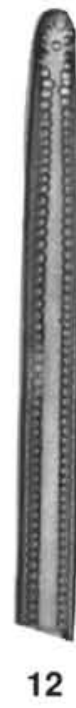

13

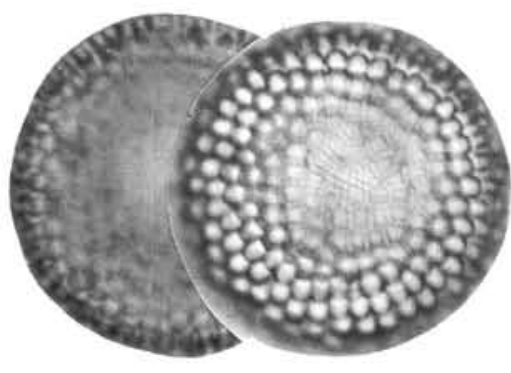

10

Plate 11. Scale bars equal $10 \mu \mathrm{m}$. 1. Coscinodiscus rhombicus, external view of valve, Sample 120-748B-8H-5, 47-48 cm. 2. Hemidiscus ovalis n. comb., external view of valve, Sample 120-751A-6H-4, 105-106 cm. 3. Asteromphalus kennettii, external view of valve, Sample 120-751A-6H-4, 105-106 cm. 4, 6. Actinocyclus ingens, external view of valve; (4) Sample 120-751A-12H-2, 105-107 cm; (6) Sample 120-748B-4H-1, 47-48 cm. 5. Azpeitia endoi, external view of valve, Sample 120-751A-12H-6, 105-107 cm. 7. Rhizosolenia hebetata f. hiemalis, girdle view, Sample 120-751A-6H-4, 105-106 cm. 8, 9. Synedra jouseana, external view of valve, Sample 120-748B-8H-5, 47-48 cm. 10. Thalassiosira fraga, external view of valve, Sample 120-748B-8H-5, 47-48 cm. 11. Hemidiscus cuneiformis, external view of valve, Sample 120-751A-7H-1, 105-106 cm. 12. Thalassiothrix longissima, external view of broken valve, Sample 120-748B-4H-1, 47-48 cm. 13. Simonseniella barboi, girdle view, Sample 120-751A-6H-4, 105-106 cm. Scale bar at bottom center is for all photographs without an individual scale bar. 

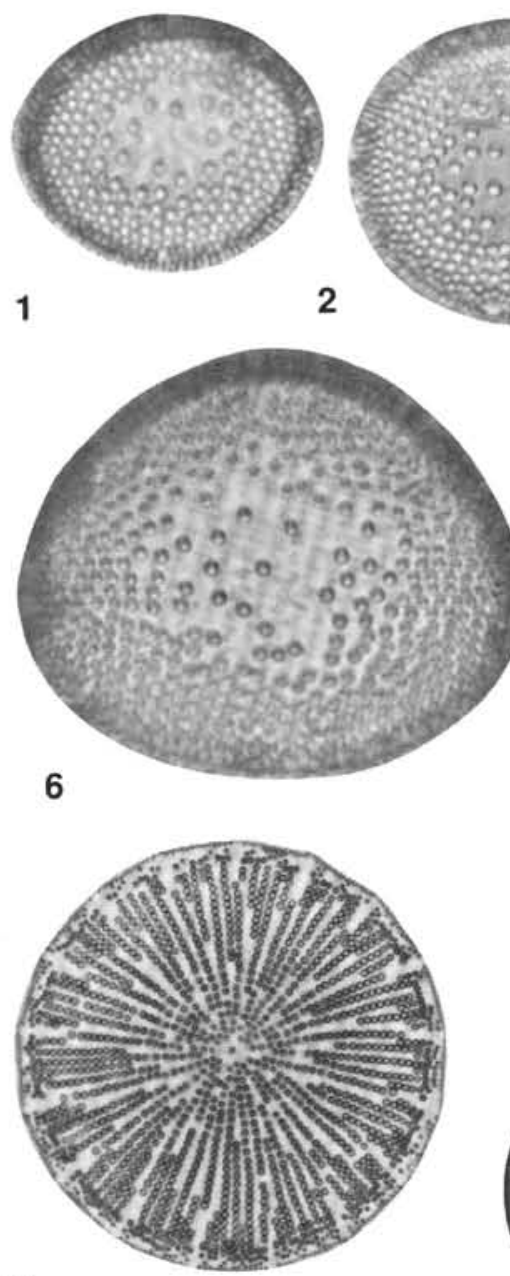

9

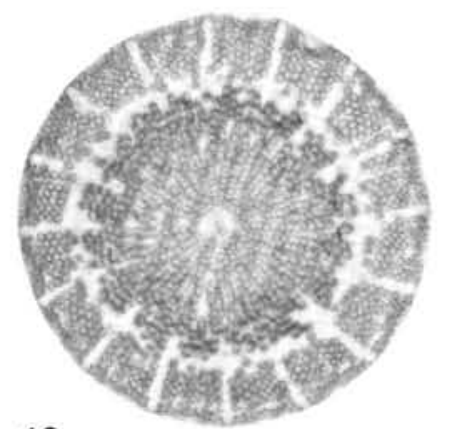

13

10

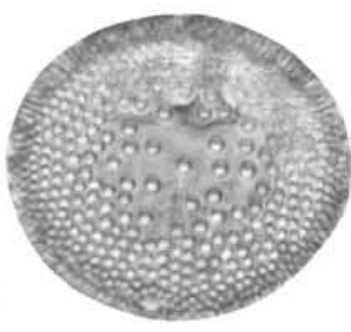

3

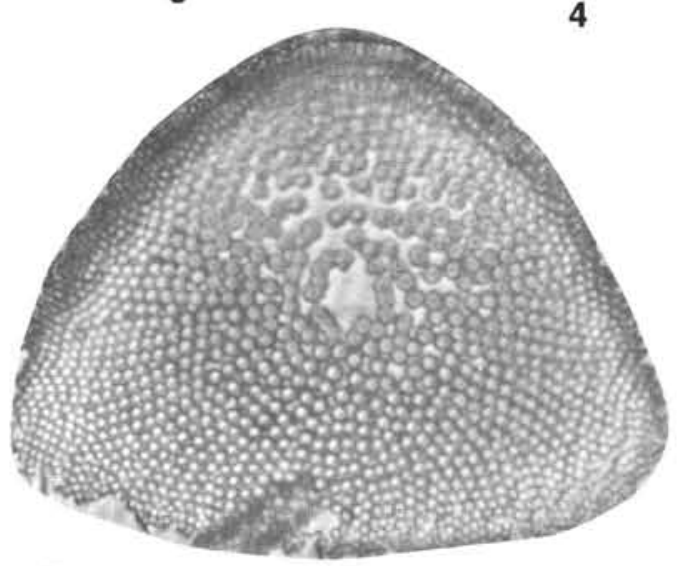

7
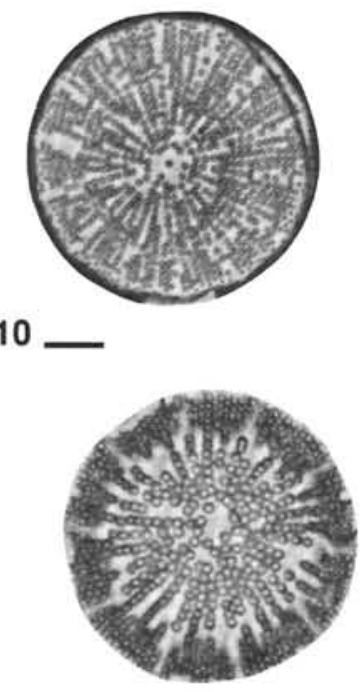

14
3

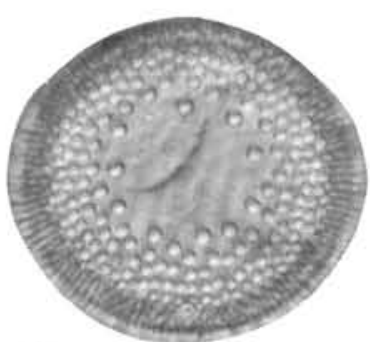

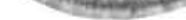

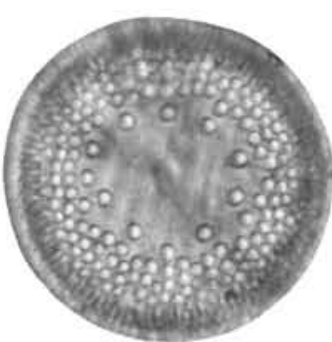

4

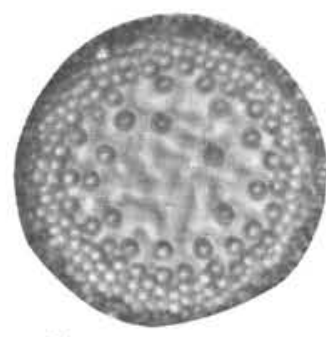

5

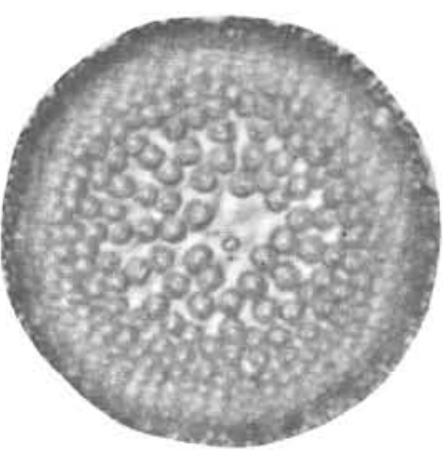

8

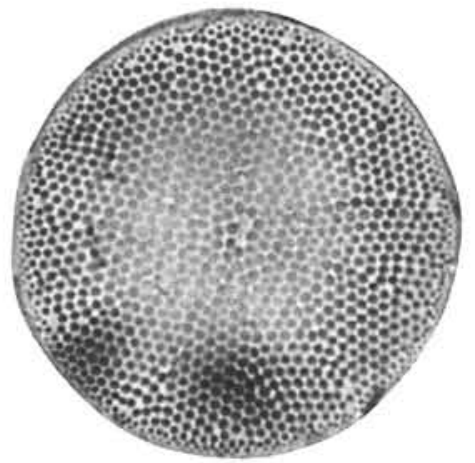

12

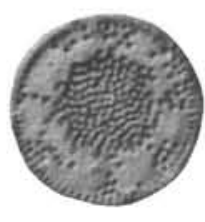

16

Plate 12. Scale bars equal $10 \mu \mathrm{m} .1-3$. Hemidiscus ovalis; (1) Sample 120-751A-5H-4, 105-107 cm; (2, 3) Sample 120-751A-5H-4, 10-11 cm. 4, 5. Actinocyclus ingens var. A; (4) Sample 120-751A-5H-4, 10-11 cm; (5) Sample 120-751A-5H-4, $105-106 \mathrm{~cm}$. 6. Hemidiscus sp. $1 \mathrm{Gersonde}$, Sample 120-751A-5H-4, 105-106 cm. 7. Hemidiscus sp. 2 Gersonde, Sample 120-751A-5H-4, 105-106 cm. 8. Actinocyclus ingens, Sample 120-751A-5H-4, 105-106 cm. 9-11. Actinocyclus sp. cf. A. actinochilus (early form; see Jouse et al., 1963), Sample 120-751A-1H-3, 51-52 cm. 12. Actinocyclus curvatulus, Sample $120-751 \mathrm{~A}-1 \mathrm{H}-1,10-11 \mathrm{~cm}$. 13-15. Actinocyclus sp. C; (13, 14) Sample 120-751A-1H-3, 51-52 cm; (15) A. actinochilus?, Sample 120-748B-2H-1, 33-34 cm. 16. Actinocyclus dimorphus? n. comb., Sample 120-751A-4H-3, 105-106 cm. Scale bar at bottom center is for all photographs without an individual scale bar. 


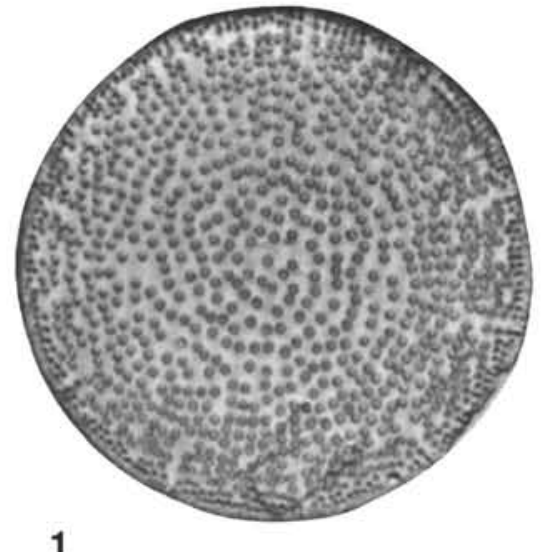

1
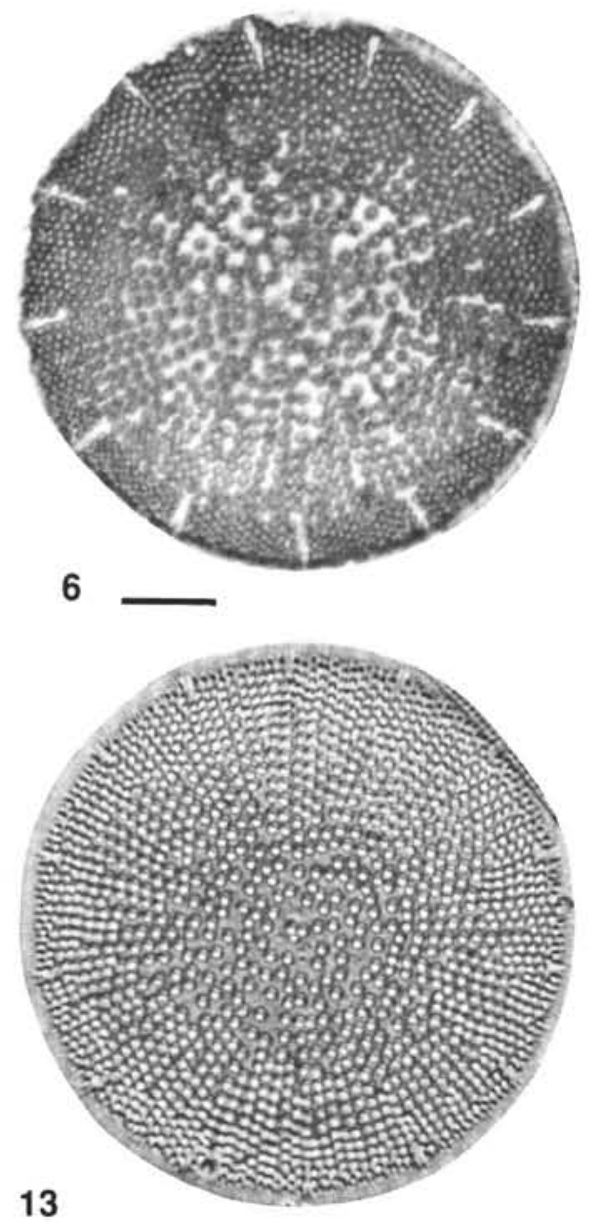

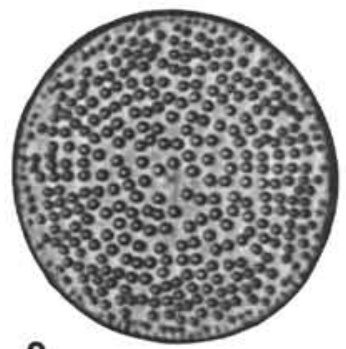

2

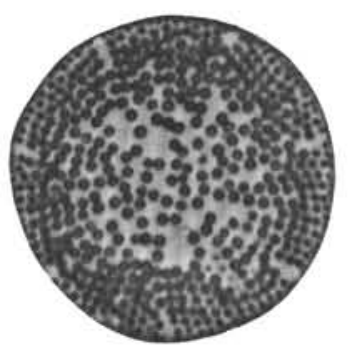

7

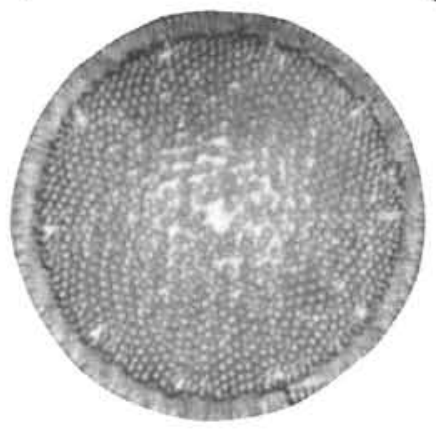

10

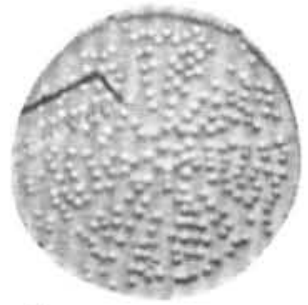

3

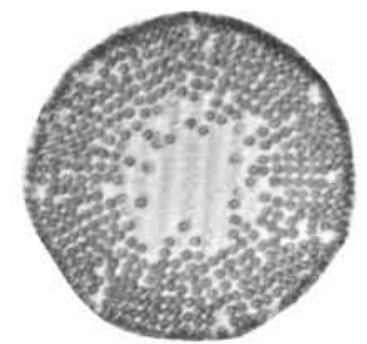

8

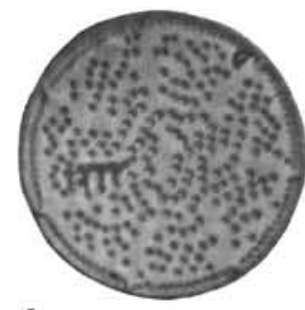

4

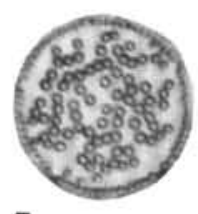

5

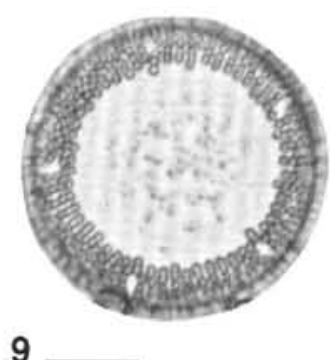

9

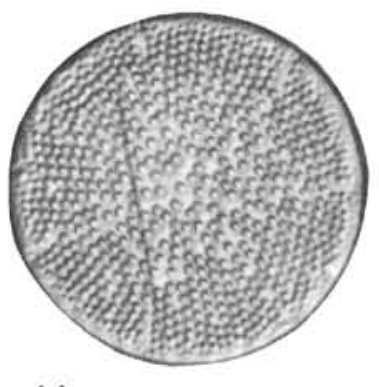

11

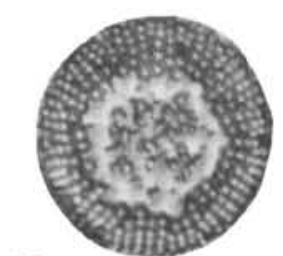

12
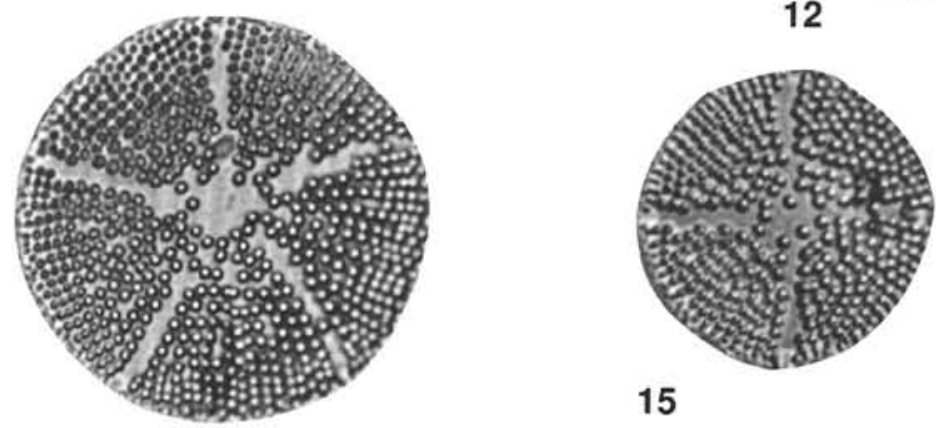

15

14

Plate 13. Scale bars equal $10 \mu \mathrm{m} . \mathbf{1}, \mathbf{2 ,}$ 6-8, 10, 11, 13. Actinocyclus karstenii; $(1,6)$ Sample 120-751A-4H-3, 105-106 cm; (2, 8) Sample 120-751A-2H-3, 105-106 cm; (7) Sample 120-751A-3H-1, 105-106 cm; (10) Sample 120-751A-4H-2, 105-106 cm; (11) Sample 120-751A-4H-3, 10-11 cm; (13) Sample 120-751A-4H-4, 10-11 cm. 3-5. Actinocyclus dimorphus n. comb., Sample 120-751A-2H-3, $105-106 \mathrm{~cm} .9$, 12. Actinocyclus sp. B, Sample 120-751A-2H-3, 105-106 cm. 14, 15. Actinocyclus fasciculatus n. sp., Sample 120-751A-2H-2, 10-11 cm; (14) holotype; (15) paratype. Scale bar at bottom center is for all photographs without an individual scale bar. 


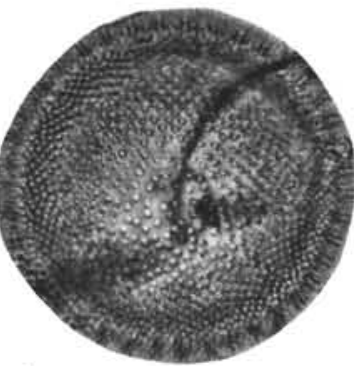

1

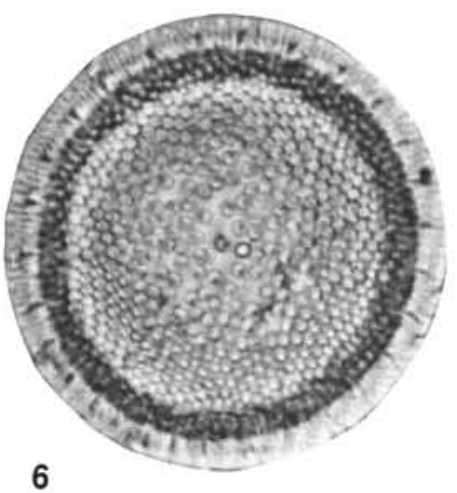

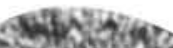

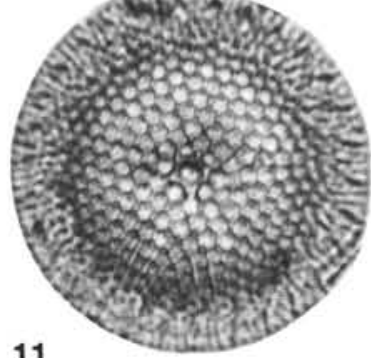

11

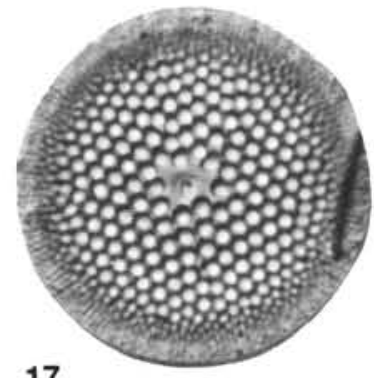

17

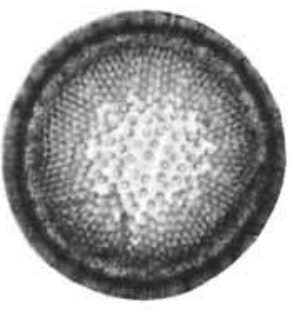

2

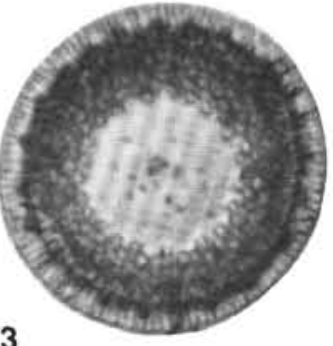

3

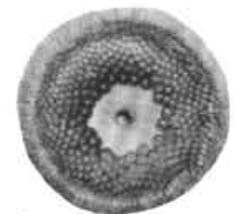

8
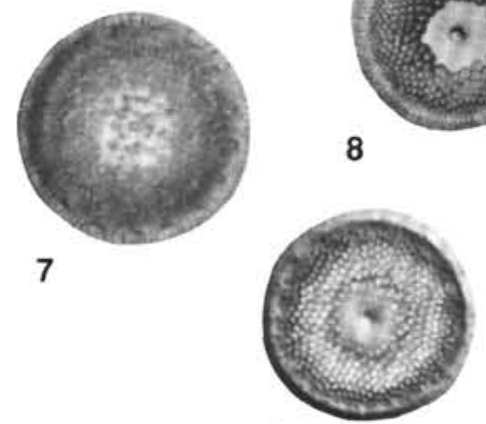

13

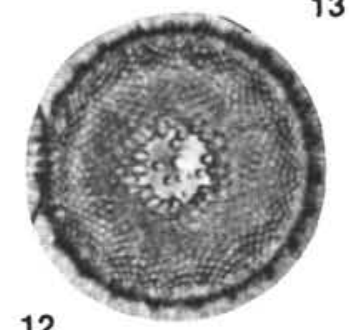

12

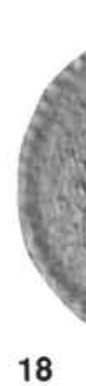

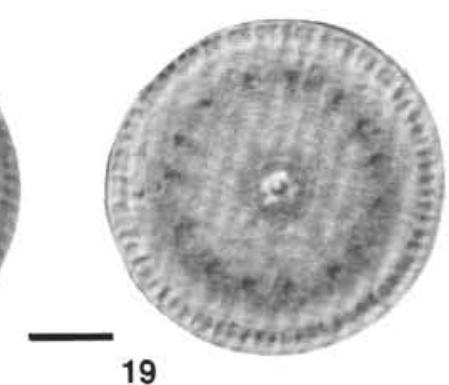

14

15

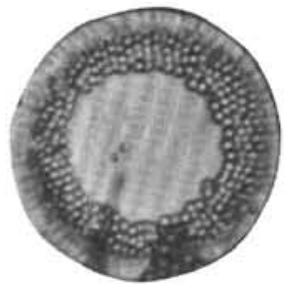

4

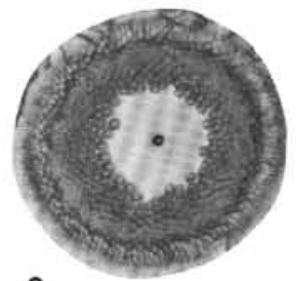

9
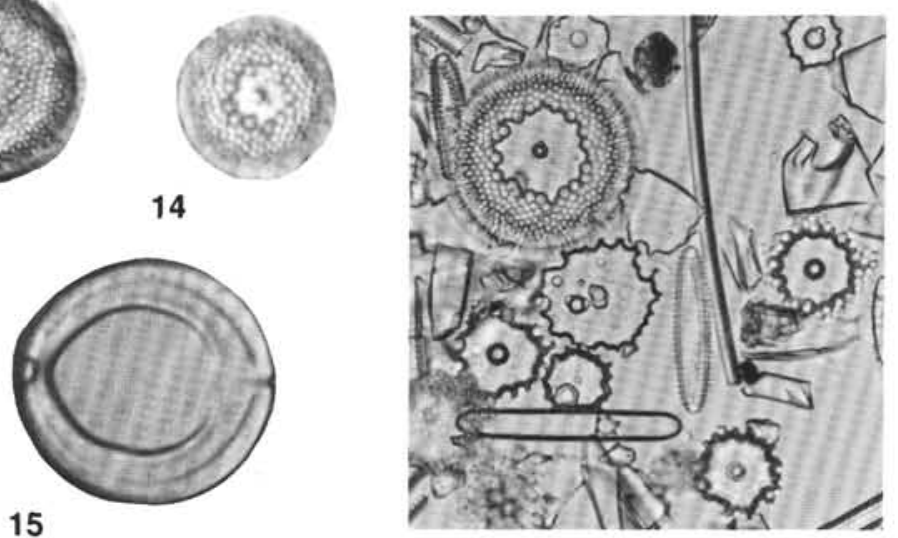

16

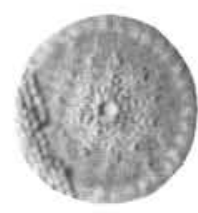

20

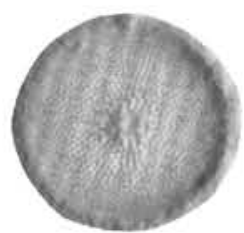

21

Plate 14. Scale bars equal $10 \mu \mathrm{m} .1,2,6,7,11,17$. Thalassiosira oliverana; (1) Sample 120-751A-1H-3, 10-11 cm; (2) Sample 120-751A-1H-3, $51-52 \mathrm{~cm} ;(6,11,17)$ Sample 120-751A-2H-2, 10-11 cm; (17) Thalassiosira oliverana (?), note coarse structure of areolae; (7) Sample 120-751A-4H-5, 105-106 cm. 3-5. Thalassiosira insigna $\mathrm{n}$. comb.; $(3,4)$ Sample 120-751A-2H-2, 105-106 cm; (5) Sample 120-747A-3H-4, 47-48 $\mathrm{cm} .8-10,16$. Thalassiosira insigna/inura transitional forms?; $(8,9)$ Sample 120-747A-3H-2, 47-48 cm; (10, 16) Sample 120-747A-3H-4, 47-48 cm. 12-14, 16. Thalassiosira inura; (12) Sample 120-751A-3H-5, 105-106 cm; (13) Sample 120-751A-4H-4, 105-106 cm; (14) Sample 120-751A-4H-5, 105-106 cm. 15. Girdle band with internal septa from Thalassiosira complicata, Sample 120-751A-3H-3, 105-106 cm. 18-20. Thalassiosira complicata; $(18,20)$ Sample 120-751A-4H-3, 10-11 cm; (19) Sample 120-751A-4H-3, 105-106 cm. 21. Thalassiosira complicata? (early form), Sample 120-751A-4H-5, 10-11 cm. Scale bar at bottom center is for all photographs without an individual scale bar 

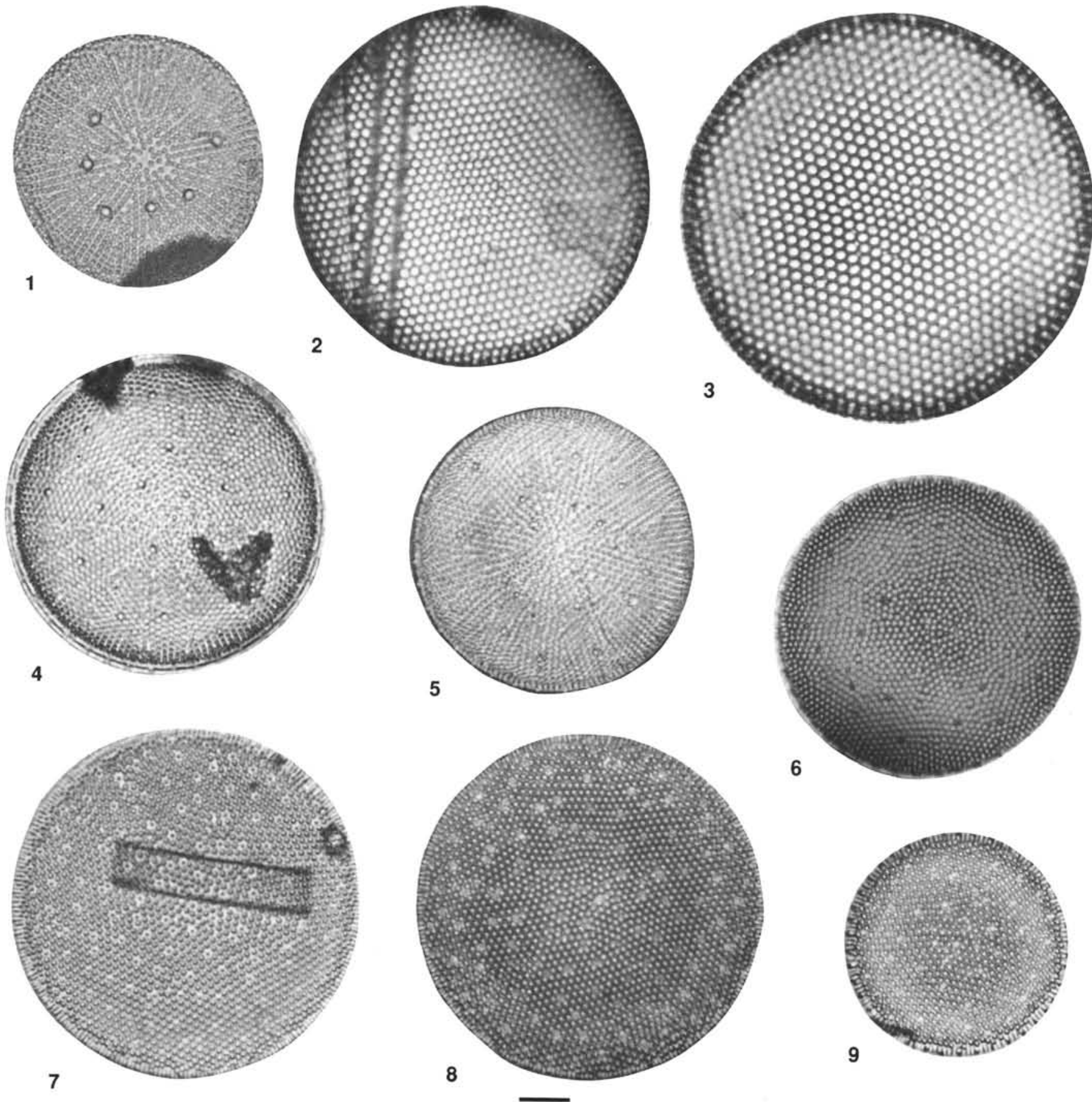

Plate 15. Scale bar equals $10 \mu \mathrm{m}$. 1. Thalassiosira vulnifica, Sample 120-751A-3H-1, 47-48 cm. 2, 3. Thalassiosira webbi, Sample 120-751A-2H-3, 105-106 cm; (3) holotype. 4-6. Thalassiosira fasciculata, Sample 120-751A-2H-3, 105-106 cm; (5) holotype; (6) paratype. 7-9. Thalassiosira striata, Sample 120-751A-3H-5, 105-106 cm; (7) holotype. 

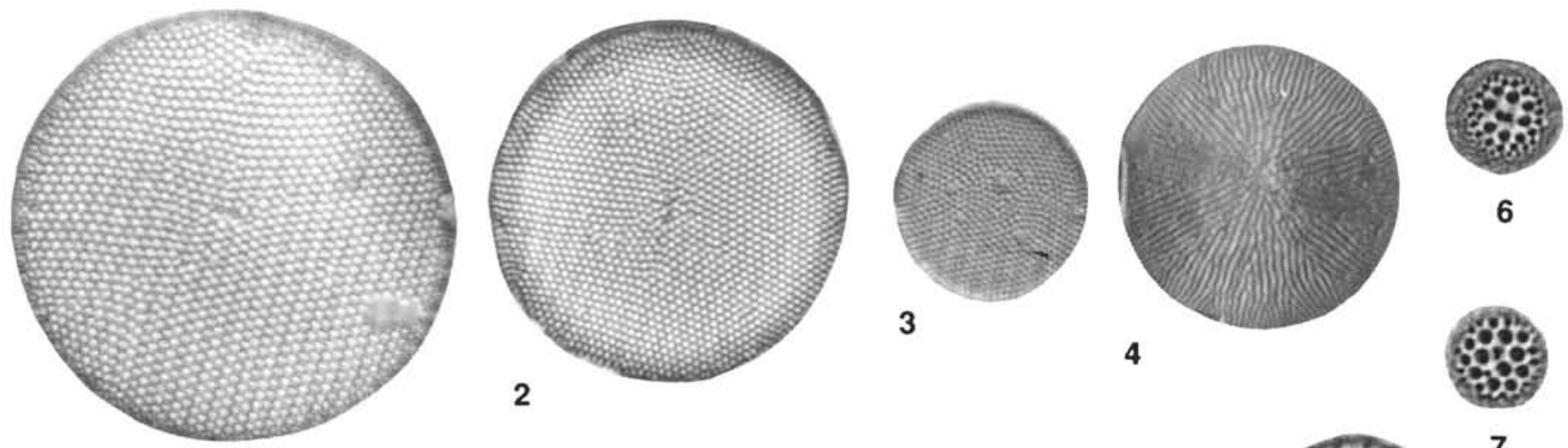

2

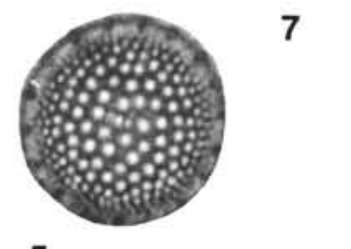

5
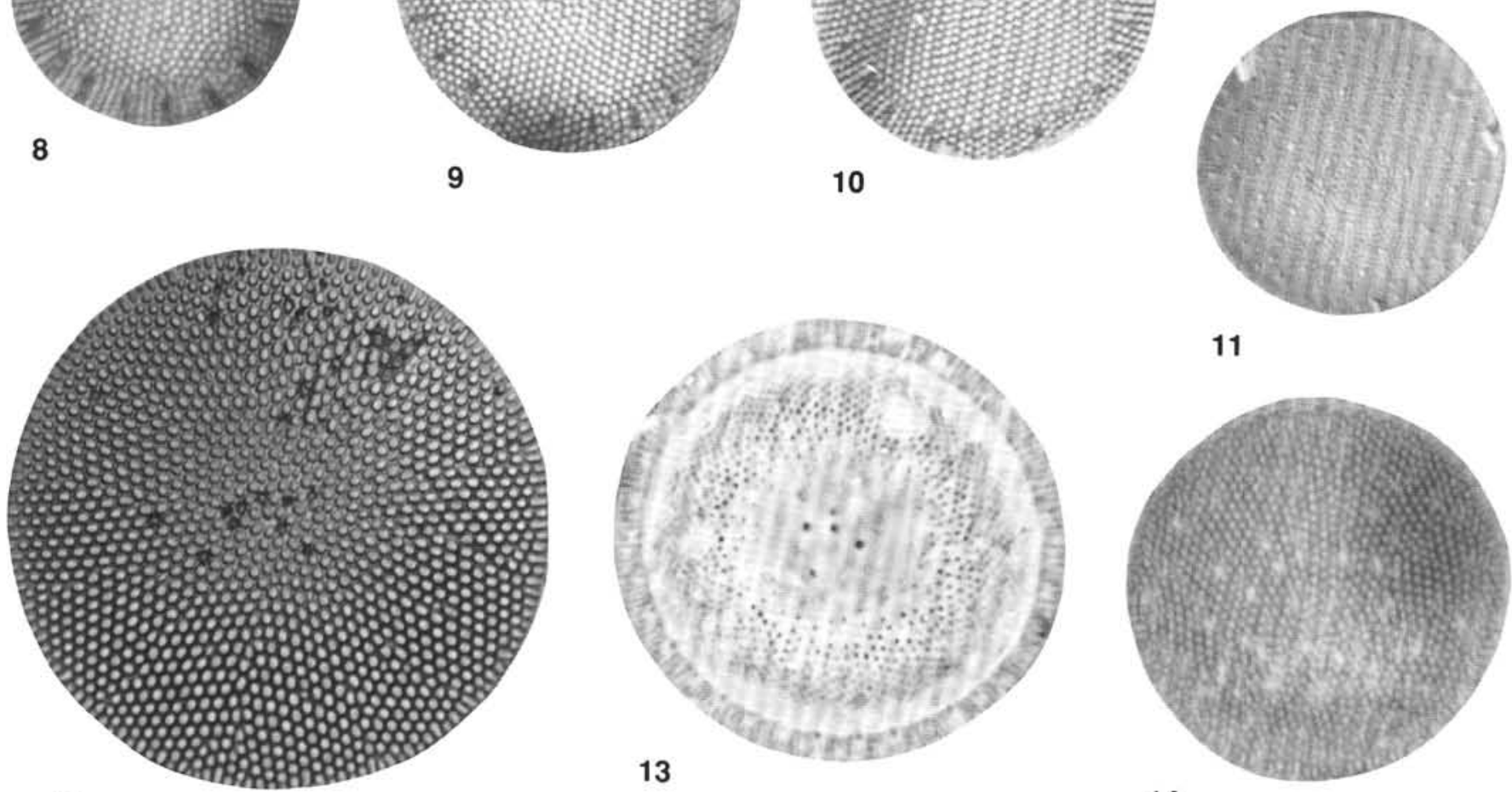

13

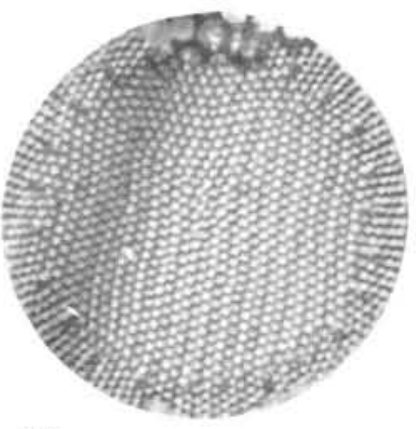

11

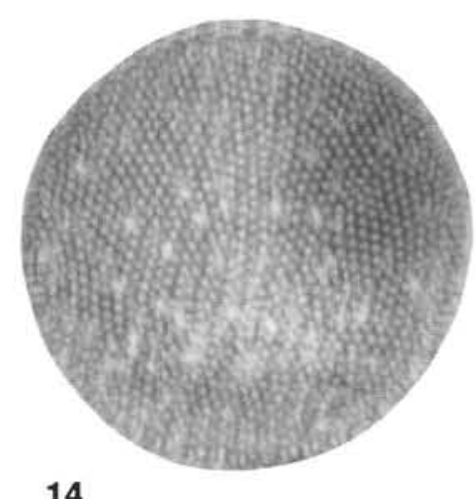

12

Plate 16. Scale bar equals $10 \mu \mathrm{m}$. 1-3. Thalassiosira ritscherii; (1) Sample 120-751A-5H-3, 105-106 cm; (2) Sample 120-751A-4H-6, 105-106 cm; (3) Sample 120-751A-5H-1, 105-106 cm. 4. Thalassiosira sp. A, Sample 120-751A-5H-4, 105-106 cm. 5-7. Thalassiosira oestrupii; (5) Sample 120-751A-2H-3, 105-106 cm; (6, 7) Sample 120-751A-1H-2, 10-11 cm. 8-10. Thalassiosira sp. C; (8) Sample 120-751A-5H-4, 105-106 cm; (9, 10) Sample 120-751A-4H-6, $105-106 \mathrm{~cm}$. 11. Porosira sp., Sample 120-751A-5H-1, 105-106 cm. 12. Thalassiosira elliptipora; (12) Sample 120-747 A-1H-CC. 13. Thalassiosira oliverana var. sparsa var. nov., Sample 120-751A-2H-2, 10-11 cm, holotype. 14. Thalassiosira striata var., Sample 120-751A-2H-3, $47-48 \mathrm{~cm}$. 


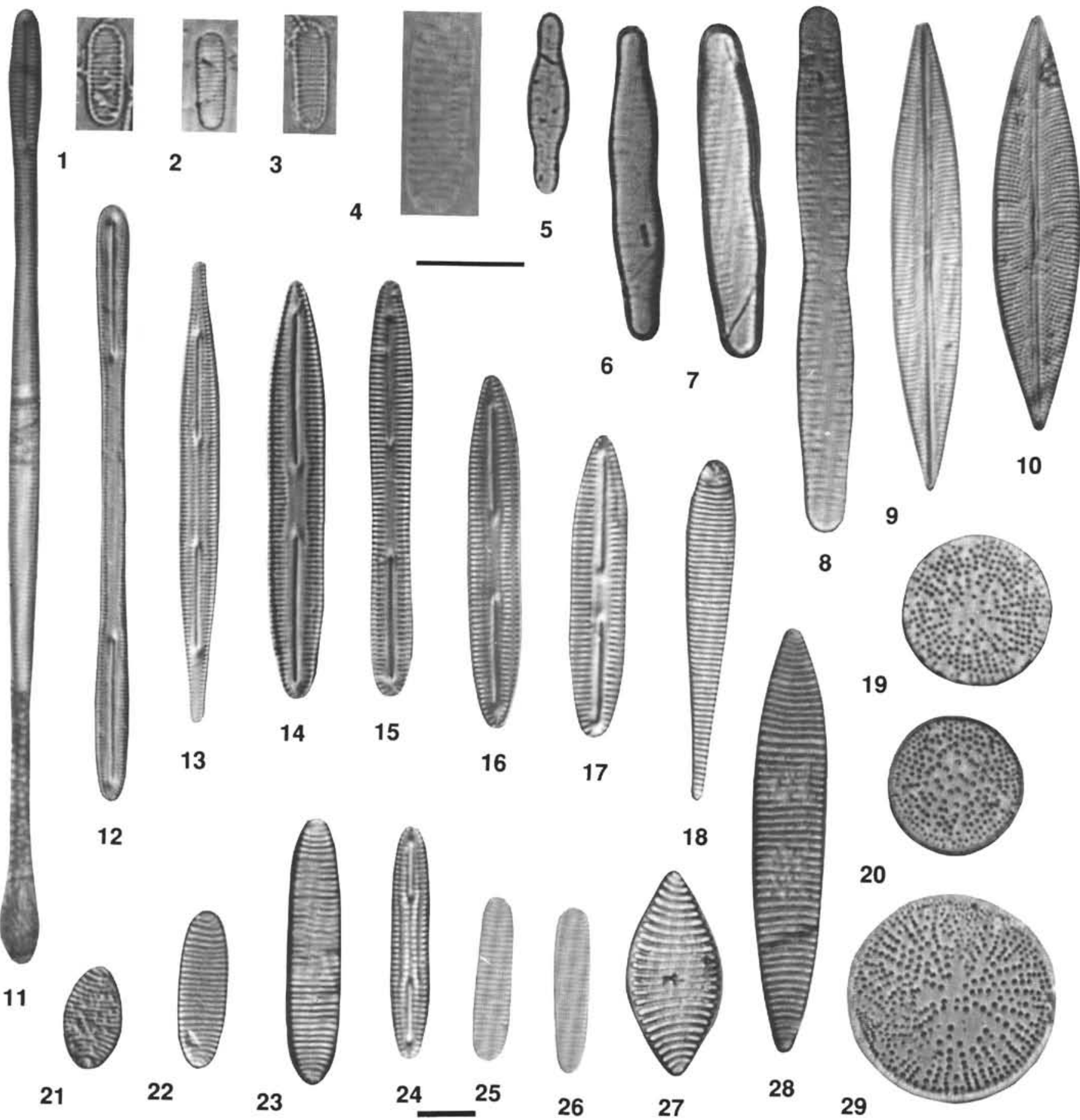

Plate 17. Scale bars equal $10 \mu \mathrm{m}$. 1-4. Nitzschia curta; (1) Sample 120-751A-3H-1, 47-48 cm; (2) Sample 120-751A-2H-1, 105-106 cm; (3) Sample 120-751A-2H-3, 10-11 cm; (4) Sample 120-751A-2H-3, 47-47 cm. 5-8. Synedra sp. 1 and 2 of Brady (1979), Sample 120-751A-2H-3, 105-106 cm. 9, 10. Navicula wisei n. sp.; (9) Sample 120-751A-3H-1, 105-106 cm, paratype; (10) Sample 120-751A-4H-2, 105-106 cm, holotype. 11. Rouxia sp. A., Sample 120-751A-2H-3, 105-106 cm. 12. Rouxia diploneides, Sample 120-751A-4H-3, 105-106 cm. 13. Rouxia isopolica, Sample 120-751A-4H-5, 105-106 cm. 14-17. Rouxia heteropolara var. A; (14) Sample 120-751A-5H-4, 10-11 cm; (15) Sample 120-751A-4H-1, 10-11 cm; (16) Sample 120-751A-5H-1, 105-106 cm; (17) Sample 120-751A-4H-5, 105-106 cm. 18. Nitzschia clementia, Sample 120-751A-4H-5, 105-106 cm. 19, 20. Actinocyclus dimorphus?, Sample 120-751A-4H-5, 105-106 cm. 21-23. Nitzschia aurica; (21, 23) Sample 120-751A-4H-2, 105-106 cm; (22) Sample 120-751A-4H-2, 105-106 cm. 24. Rouxia antarctica, Sample 120-751A-3H-4, 105-106 cm. 25, 26. Nitzschia praecurta, Sample 120-751A-5H-4, 105-106 cm. 27, 28. Nitzschia barronii; (27) Sample 120-751A-2H-3, 105-106 cm; (28) Sample 120-751A-3H-4, 105-106 cm. 29. Actinocyclus maccollumi n. sp., Sample 120-751A-2H-2, 10-11 cm, holotype. Scale bar at bottom center is for all photographs without an individual scale bar. 


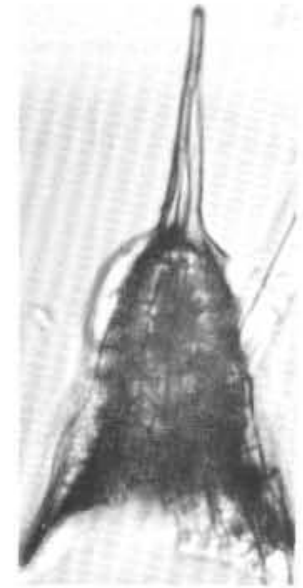

1

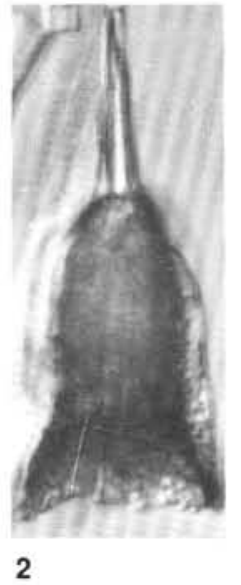

2

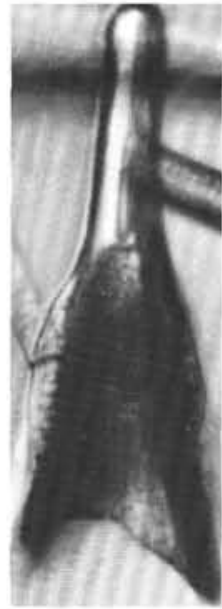

3

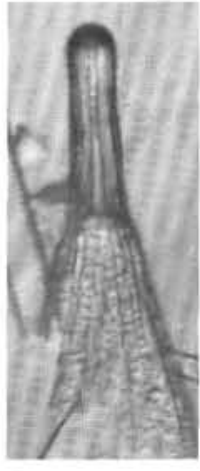

4

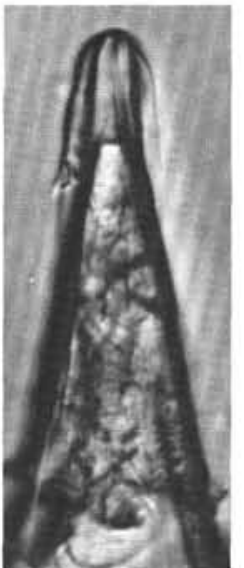

5

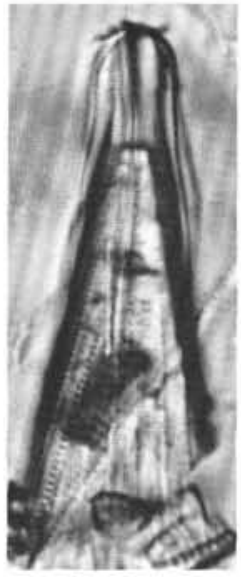

6

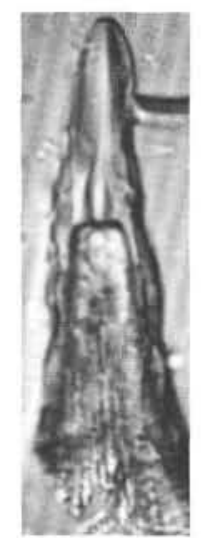

7

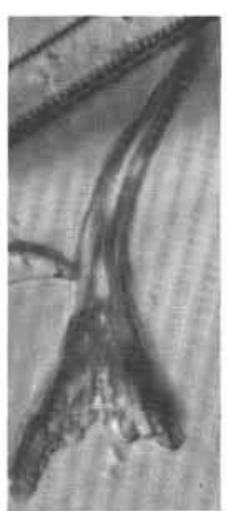

13

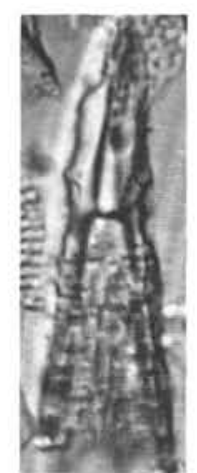

8

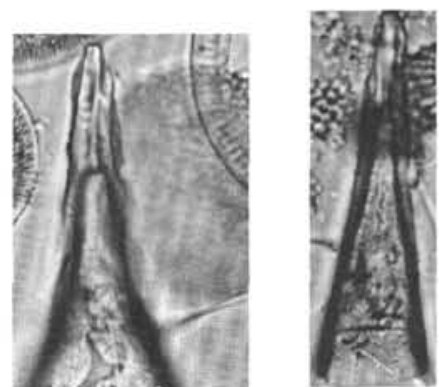

10

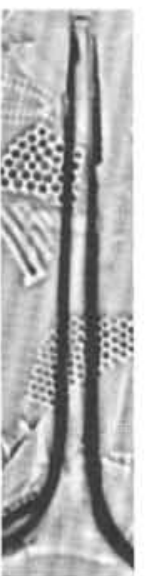

16

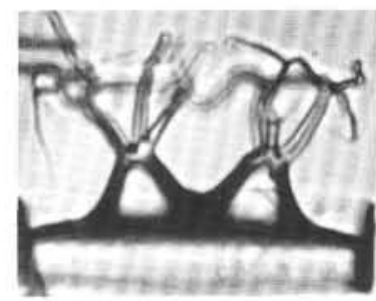

11
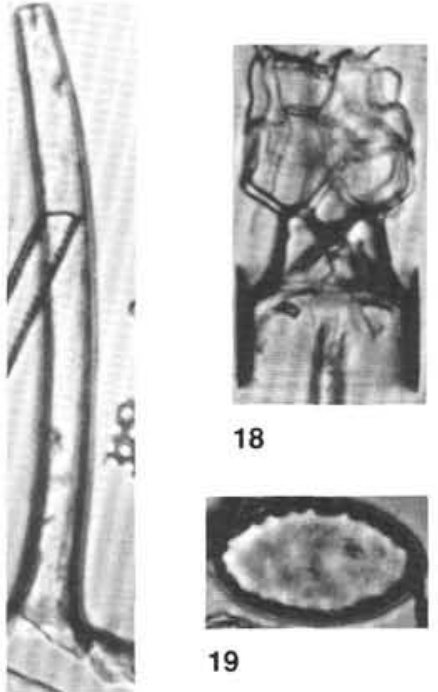

18

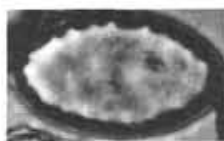

19

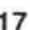

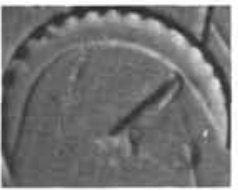

12

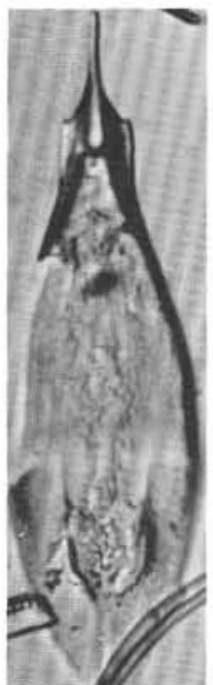

20

Plate 18. Scale bars equal $10 \mu \mathrm{m}$. 1, 2. Rhizosolenia costata, Sample 120-751A-4H-4, 105-106 cm. 3, 4. Rhizosolenia costata var. A; (3) Sample 120-751A-4H-5, 105-106 cm; (4) Sample 120-751A-4H-6, 105-106 cm. 5, 6. Rhizosolenia sp. C, Sample 120-751A-4H-4, 10-11 cm. 7-10. Rhizosolenia sp. D; $(7,8)$ Sample 120-751A-2H-2, 10-11 cm; $(9,10)$ Sample 120-751A-1H-3, 10-11 cm. 11, 18, 19. Chaetoceros (Dicladia) lorenzianus resting spore, Sample 120-751A-2H-3, 105-106 cm. 12. Dactyliosolen antarcticus, Sample 120-751A-2H-3, 10-11 cm. 13, 14. Rhizosolenia sp. B, Sample 120-751A-4H-2, 105-106 cm. 15, 17. Rhizosolenia alata group, Sample 120-751A-3H-5, 105-106 cm. 16. Rhizosolenia sp. A, Harwood et al. (1989b), Sample 120-751A-3H-5, 10-11 cm. 20. Rhizosolenia styliformis, Sample 120-751A-3H-2, 105-106 cm. Scale bar at bottom center is for all photographs without an individual scale bar. 

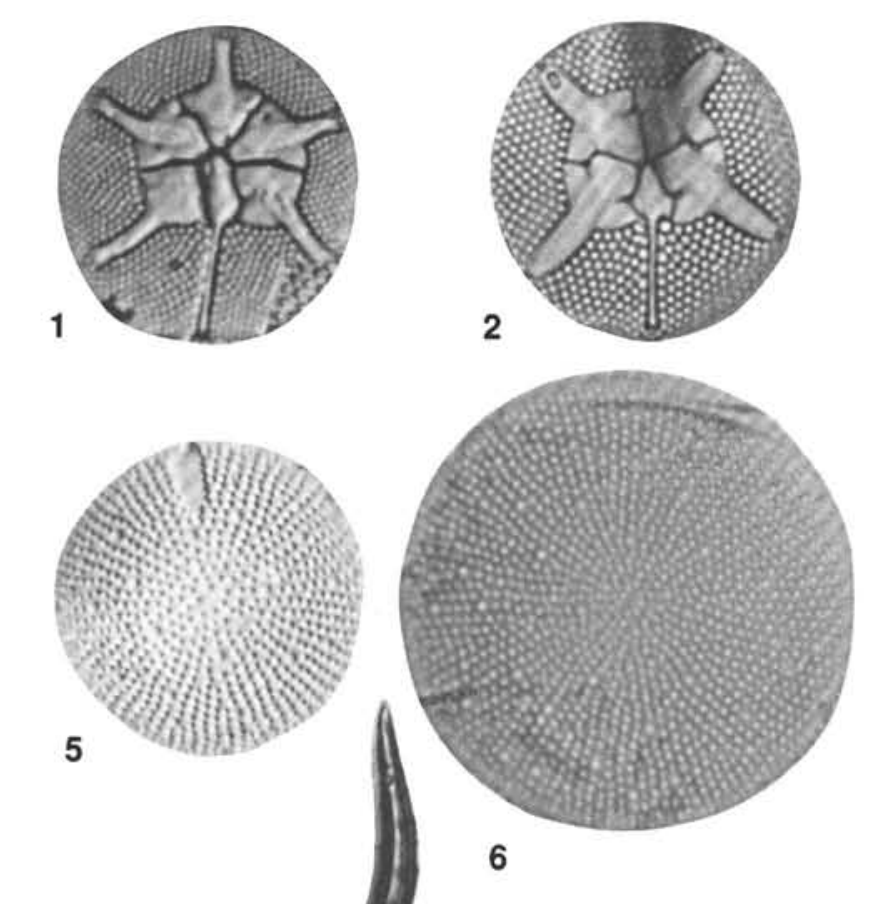
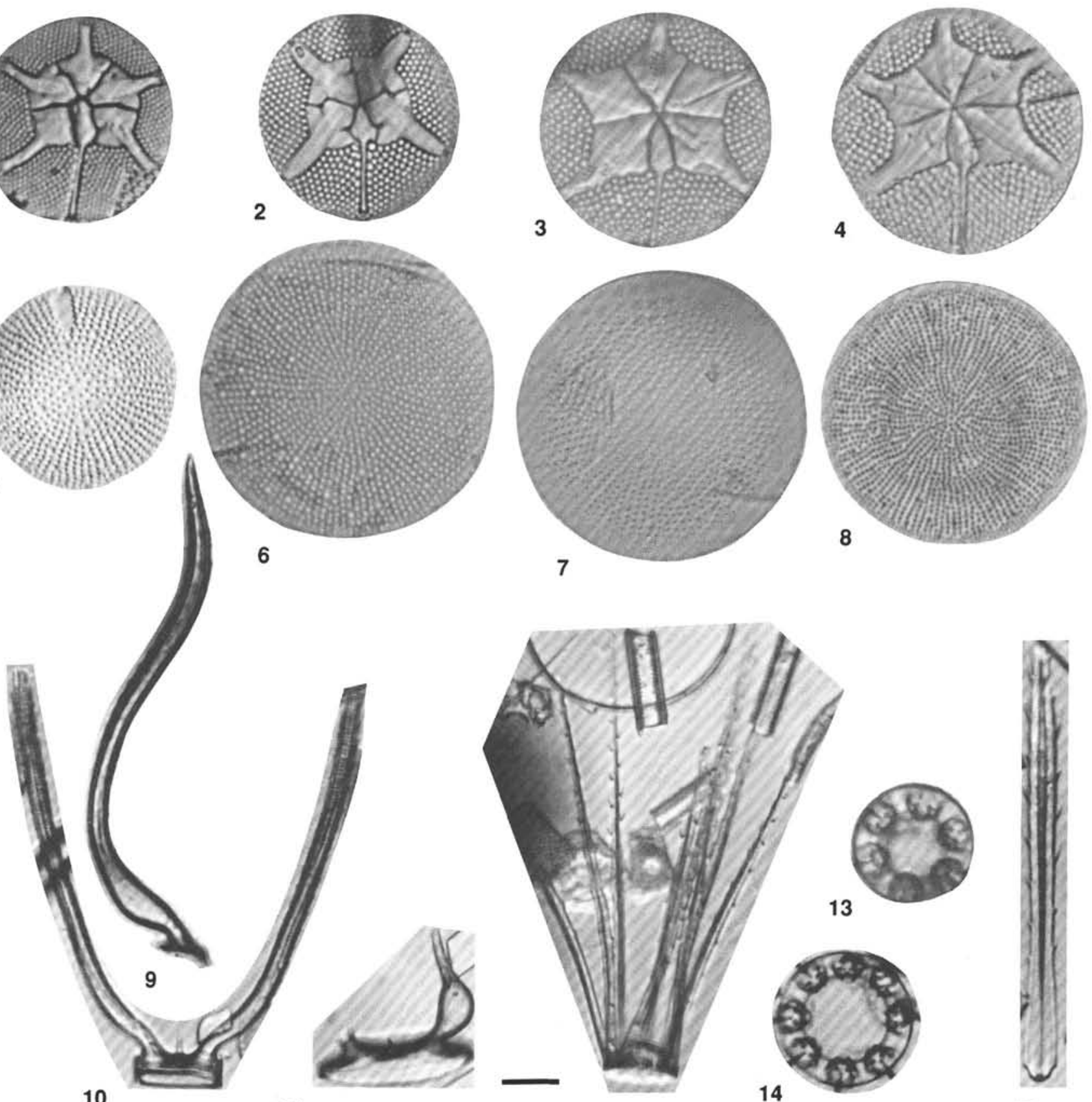

11
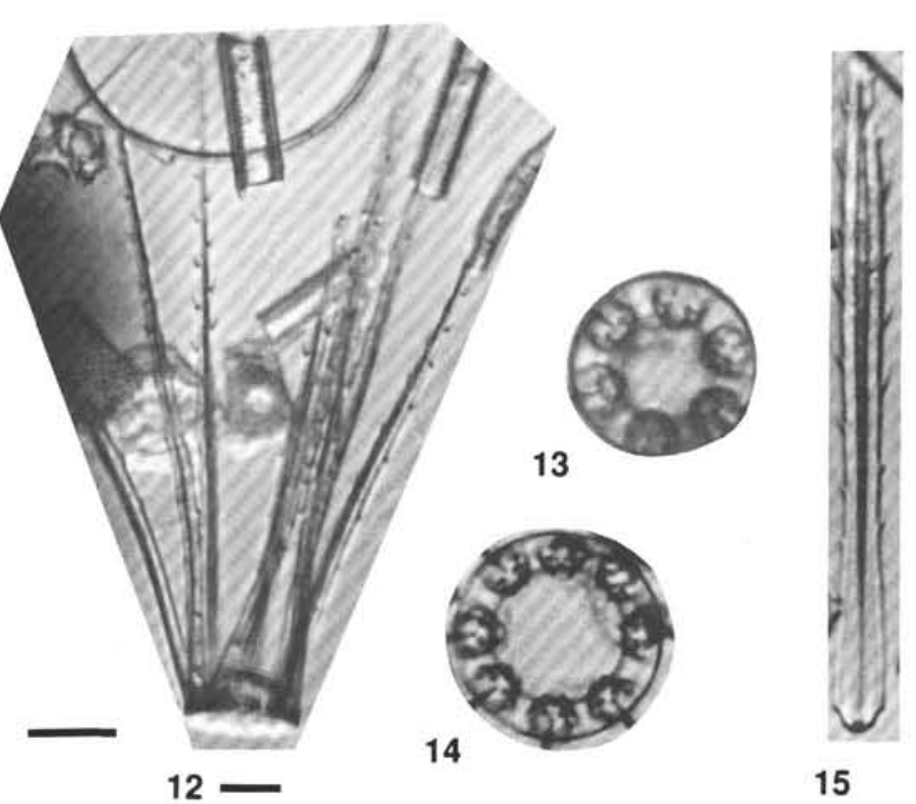

15

Plate 19. Scale bars equal $10 \mu \mathrm{m}$. 1, 2. Asteromphalus parvulus; (1) Sample 120-751A-2H-3, 105-106 cm; (2) Sample 120-751A-1H-1, 105-106 cm. 3, 4. Asteromphalus concavus n. sp., Sample 120-751A-5H-4, 105-106 cm; (3) holotype; (4) paratype. 5-7. Thalassiosira sp. B; (5) Sample 120-748B-2H-1, 117-118 cm; (6, 7) Sample 120-747A-1H-CC. 8. Thalassiosira lentiginosa, Sample 120-751A-2H-2, 105-106 cm. 9-11. Chaetoceros sp. A, Sample 120-751A-4H-5, 105-106 cm. 12-15. Corethron criophilum; (12) Sample 120-751A-4H-5, 105-106 cm; (13-15) Sample 120-751A-2H-3, 105-106 cm. Scale bar at bottom center is for all photographs without an individual scale bar. 